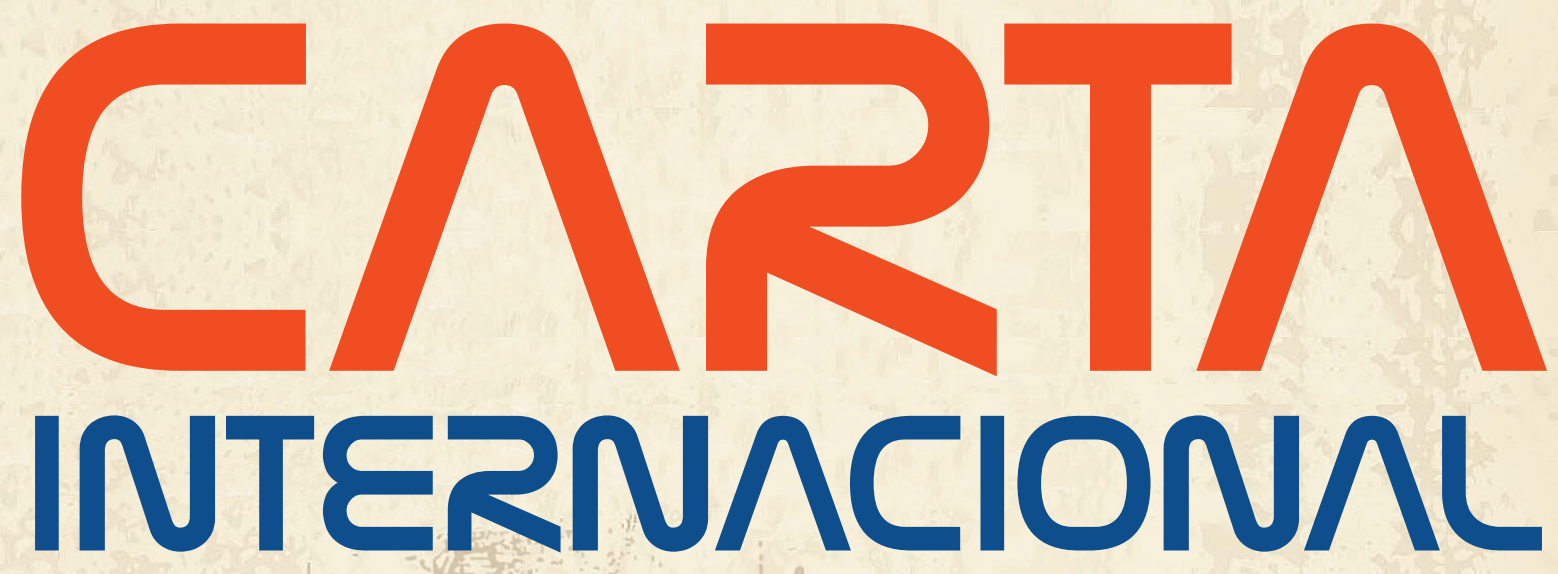

PUBLICAÇÃO DA ASSOCIAÇÃO BRASILEIRA DE RELAÇÕES INTERNACIONAIS

ISSN 2526-9038 • V. 12, No 3, setembro/dezembro de 2017 • DOI: 10.12530/ci.v12n3.2017

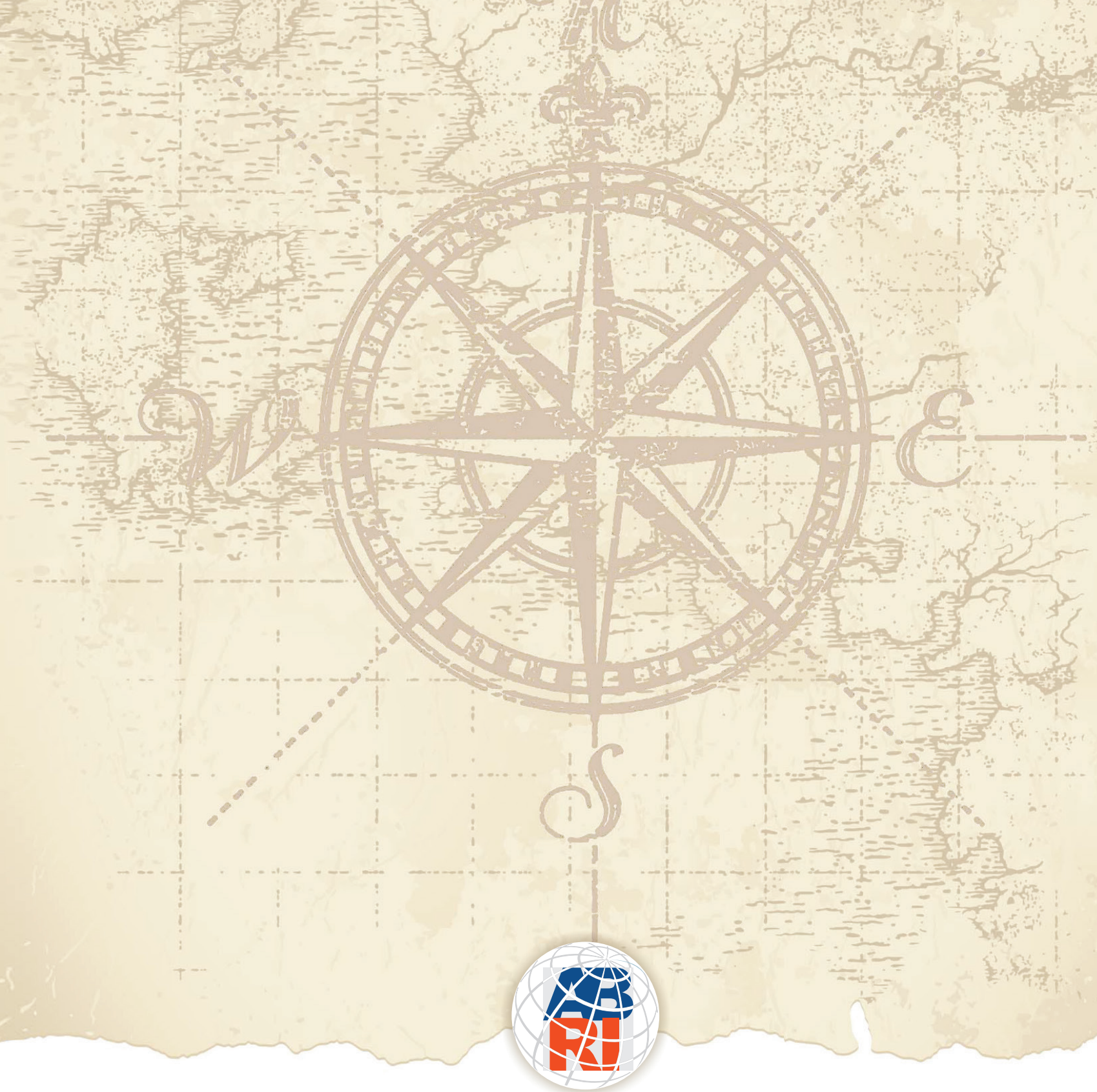




\section{Expediente}

Carta Internacional é uma revista eletrônica de publicação quadrimestral dedicada ao debate sobre as questões mais relevantes das relações internacionais sob a perspectiva brasileira. As opiniões expressas nos artigos assinados são de responsabilidade exclusiva de seus autores e não expressam as opiniões da Associação Brasileira de Relações Internacionais (ABRI).

A Revista Carta Internacional foi fundada em 1993 por José Augusto Guilhon Albuquerque, no Núcleo de Pesquisas em Relações Internacionais da Universidade de São Paulo (NUPRI/USP). Em 2011 tornou-se a publicação científica da Associação Brasileira de Relações Internacionais (ABRI).

Carta Internacional é publicada pela Associação Brasileira de Relações Internacionais (ABRI). A revista está disponível para download gratuito, em formato PDF, no endereço:

http://www.cartainternacional.abri.org.br

\section{Editora Chefe:}

Matilde de Souza

\section{Editora Associada:}

Letícia Carvalho

\section{Editores Assistentes}

Rebeca Caeiro e Mateus Silva

\section{Diagramação:}

Samuel Tabosa

\section{Revisão:}

Luís Fernando dos Reis Pereira

\section{Secretaria da Carta Internacional:}

Airá Eventos Técnico-Científicos

\section{Conselho Científico:}

AAmado Luiz Cervo, André Singer, Andrew Hurrell, Anthony Pereira, Antônio Carlos Lessa, Arlene Tickner, Carlos Eduardo Lins da Silva, David Mares, Eduardo Viola, Elizabeth Balbachevsky, Félix Peña, Fernando Augusto Albuquerque Mourão, Gary Hufbauer, Gilson Schwartz, Gladys Lechini, Gustavo Vega-Cánovas,
Henrique Altemani de Oliveira, José Augusto Guilhon Albuquerque, Luis Olavo Baptista, Margarita Silvia Olivera, Maria Cristina Cacciamali, Maria Regina Soares de Lima, Paulo Fagundes Visentini, Paulo Lavigne Esteves, Peter Demant, Rafael Antônio Duarte Villa, Sean Burges e Tullo Vigevani.

Redes Sociais:

Facebook: Carta Internacional

Twitter: @CartaAbri

LinkedIn: Revista Carta Internacional

Academia.edu: Revista Carta Internacional

\section{Associação Brasileira de Relações Internacionais (ABRI)}

\section{Presidente:}

Eugênio Pacelli Lazzarotti Diniz Costa (PUC Minas)

\section{Secretária Executiva:}

Layla Ibrahim Abdallah Dawood (UERJ)

Secretário Executivo Adjunto:

Haroldo Ramanzini Junior (UFU)

\section{Tesoureira:}

Graciela De Conti Pagliari (UFSC)

\section{Diretores:}

Cristina Soreanu Pecequilo (UNIFESP)

Ana Flávia Barros-Platiau (UnB)

Carolina Moulin (PUC-Rio)

Marcos Ferreira da Costa Lima (UFPE)

Conselho Fiscal:

Henrique Altemani de Oliveira (UEPB)

Túlio Sérgio Henriques Ferreira (UFPB)

\section{Correspondência:}

Avenida Dom José Gaspar, 500 — Prédio 04 - Sala 01 Coração Eucarístico Belo Horizonte, MG — CEP: 30535-901 Tel.: + 55 (31) 3241-5123

email: cartainternacional@abri.org.br

(C) 2017 Associação Brasileira de Relações Internacionais (ABRI). Todos os direitos reservados. 


\section{Sumário}

O conceito de Ataque Global Imediato: premissas equivocadas, consequências perigosas | Conventional Prompt Global Strike:

wrong premises, risky consequences $\mid 5$

Guilherme Simionato dos Santos

Marco Cepik

As três tendências da guerra cibernética: novo domínio, arma combinada e arma estratégica | The three trends of cyberwarfare: new domain, combined arms and strategic weapon | 30

Augusto W. M. Teixeira Júnior

Gills Vilar-Lopes

Marco Túlio Delgobbo Freitas

As disputas sino-vietnamitas no Mar do Sul: desafios para além da questão regional | The sino-vietnamite disputes in the South Sea: challenges beyond the regional issue | 54

Diego Pautasso

Alexandre Cesar Cunha Leite

Gaio Doria

O papel do Brasil na evolução das Operações de Paz | Brazilian contribution in the peace operations' evolution | 77

Anselmo de Oliveira Rodrigues

Eduardo Xavier Ferreira Glaser Migon

O histórico da segurança humana e o (des)encontro das agendas de desenvolvimento e segurança | The history of human security and the (mis) match of the development and security agendas | 104

Raquel Maria de Almeida Rocha 
“Ganhei na loteria! Mas e o prêmio?”: a mobilização sócio-legal do direito internacional dos direitos humanos no caso da guerrilha do Araguaia | "I have won the lottery! What about the prize?": the socio-legal mobilization of the international human rights law in the case of the Araguaia guerrilla movement | 130

Bruno Boti Bernardi

Temas de Relações Internacionais nos discursos de posse de presidentes e de chanceleres brasileiros (1995-2017) | Issues of International Relations in inauguration speeches of brazilian presidents and chancellors (1995-2017) | 153 Felipe Ferreira de Oliveira Rocha

O diálogo entre saúde e política externa brasileira nos governos de Fernando Henrique Cardoso (1995-2002) e Luiz Inácio Lula da Silva (2003-2010) | The dialogue between health and the brazilian foreign policy in the governments of Fernando Henrique Cardoso (1995-2002) and Luiz Inácio Lula da Silva (2003-2010) | 175

Tayná Marques Torres Barboza

Leticia Pinheiro

Fernando Pires-Alves

A condição semiperiférica do Brasil na economia-mundo capitalista: novas evidências | The semiperipheral condition of Brazil in the capitalist World-economy: further evidence | 199

Helton Ricardo Ouriques

Pedro Antonio Vieira

Energiewende: german energy policy in times of green transition Energiewende: política energética alemã em tempos de transição verde | 229 Solange Reis 


\title{
O conceito de Ataque Global Imediato: premissas equivocadas, consequências perigosas
}

\author{
Conventional Prompt Global Strike: \\ wrong premises, risky consequences
}

DOI: $10.21530 /$ ci.v12n3.2017.684

Guilherme Simionato dos Santos ${ }^{1}$

Marco Cepik²

\section{Resumo}

O artigo analisa criticamente o conceito estadunidense de Ataque Convencional Global Imediato (Conventional Prompt Global Strike - CPGS), bem como suas implicações para a segurança internacional. Trata-se de iniciativas que buscam desenvolver a capacidade de atacar - de forma convencional, precisa e sem depender de bases avançadas - alvos localizados a longas distâncias (pelo menos $1.500 \mathrm{~km}$ ) em um curto período de tempo (velocidades acima de Mach 5). O conceito tem duas premissas equivocadas. A primeira corresponde ao que Patrick Porter (2015) chamou de "globalismo" tático, ou seja, a crença de que ataques convencionais em escala global não seriam mais constrangidos pela distância. A segunda é o que James Acton (2013) chamou de "mito da bala de prata", a busca por uma inovação capaz, por si só, de reverter tendências estratégicas e realidades políticas. Os projetos ligados ao conceito CPGS enfrentam dificuldades técnicas, orçamentárias e políticas. Caso sejam bem-sucedidos, suas consequências são perigosas. Em primeiro lugar, estimulam a competição e a emulação de soluções preemptivas com tempo operacional acelerado. Em segundo lugar, como o CPGS ameaça a capacidade de segundo ataque (retaliação) nuclear das outras grandes potências, sua implementação aumenta a instabilidade política mundial e os riscos de ultrapassagem não acidental do limiar nuclear.

Palavras-chave: Segurança Internacional. Estudos Estratégicos. Projeção de Força.

\section{Abstract}

The article analyzes, from a critical point of view, the American concept of Conventional Prompt Global Strike (CPGS) as well as its implications for international security. These are initiatives that seek to develop the ability to attack targets at long distances (at least

1 Programa de Pós-Graduação em Estudos Estratégicos Internacionais da Universidade Federal do Rio Grande do Sul (UFRGS), em Porto Alegre/RS, Brasil. E-mail: simionato.guilherme@gmail.com

2 Programa de Pós-Graduação em Estudos Estratégicos Internacionais da Universidade Federal do Rio Grande do Sul (UFRGS), em Porto Alegre/RS, Brasil. E-mail: marco.cepik@ufrgs.br

Artigo submetido em 25/06/2017 e aprovado em 03/11/2017. 
$1,500 \mathrm{~km}$ ) in a short period of time (speeds above Mach 5) in a conventional, precise and independent manner. The concept is based upon two false premises. The first corresponds to what Patrick Porter (2015) called tactical "globalism", that is, the belief that conventional attacks on a global scale would no longer be constrained by distance. The second is what James Acton (2013) called the "silver bullet myth", the search for an innovation capable of reversing strategic trends and political realities. Projects linked to the CPGS concept face technical, budgetary and political difficulties. If they are successful, their consequences are dangerous. First, they stimulate competition and the emulation of preemptive solutions with accelerated operational tempo. Secondly, as the CPGS threatens the second nuclear strike capability of other Great Powers, its implementation increases global political instability and the risks of non-accidental nuclear confrontation.

Keywords: International Security. Strategic Studies. Force Projection.

\section{Introdução}

O debate teórico sobre os condicionantes da projeção de força militar e seus efeitos sobre a distribuição de poder no sistema internacional é central nas teorias realistas da política internacional. Como se sabe, tanto as vertentes realistas estruturais (WALTZ, 1979; GILPIN, 1981; MEARSHEIMER, 2007), quanto as perspectivas neoclássicas (LOBELL, RIPSMAN, TALIAFERRO, 2009) identificam como critérios fundamentais de mudança os esforços que cada país faz para alterar a balança de poder. Recentemente, a discussão de tais critérios tem ficado excessivamente restrita às questões de proliferação, equilíbrio e dissuasão nuclear (LIEBER, PRESS, 2006; MORGAN, 2012; LONG, GREEN, 2015; CIMBALA, 2016; DINIZ, 2016; LI, TONG, 2016; VOLPE, 2017). No entanto, um aspecto importante e negligenciado da discussão sobre as relações de poder entre as grandes potências diz respeito exatamente às tentativas de mudar o equilíbrio de força por meio de inovações tecnológicas das capacidades militares convencionais com potencial para alterar o equilíbrio estratégico.

Na verdade, falta ao debate teórico contemporâneo uma compreensão sobre as inter-relações entre as capacidades nucleares e convencionais em dinâmicas interativas caracterizadas por incerteza e fragilização de facto dos regimes internacionais de não proliferação ${ }^{3}$. Por isso, este artigo analisa o esforço dos

3 Nota-se que o Tratado sobre a Proibição de Armas Nucleares, aprovado em julho de 2017 com o apoio de 122 países, não foi assinado pelas atuais potências nucleares e tem pouca incidência sobre as dinâmicas políticomilitares entre tais potências, incluindo-se as questões sobre as armas nucleares táticas ou sobre o uso de sistemas convencionais com efeito estratégico (ANDREASEN, 2017). 
Estados Unidos para desenvolver capacidades convencionais de ataque global. O conceito estadunidense de Ataque Convencional Global Imediato (Conventional Prompt Global Strike - CPGS) surgiu com a justificativa de propiciar uma defesa preventiva contra ataques deliberados ou acidentais sem romper o limiar nuclear. Assim como a Defesa Nacional Antimíssil (NMD), o CPGS dificilmente pode ser classificado a partir de uma dicotomia defensiva-ofensiva (MARTINS, CEPIK, 2014). Ou, como caracterizou Lora Saalman (2014), a análise do "Escudo" (NMD), seria incompleta sem a análise da "Lança" (CPGS). Portanto, é preciso discutir criticamente as premissas que informam tal conceito, bem como as dificuldades de implementação prática e as implicações que sua eventual materialização poderá trazer para a segurança internacional.

Mesmo considerando a forte polarização política dentro dos Estados Unidos, é possível identificar no debate estratégico norte-americano, desde o final da Guerra Fria, certa persistência de teses que subestimam a necessidade de forças terrestres, que enfatizam capacidades ofensivas e mesmo que negam a existência de limites humanos (econômicos, políticos, culturais) e geográficos para a projeção de força. São concepções centradas na crença de que a essência revolucionária da tecnologia estaria tornando obsoletos todos os conceitos e práticas associados ao fazer da guerra. Tais teses, discursos, teorias e conceitos são bastante disseminados no pensamento militar norte-americano, tendo sido designados coletivamente por Patrick Porter (2015) como globalismo ${ }^{4}$. Para dizê-lo desde já, a perspectiva dos autores deste artigo é crítica ao globalismo na acepção atribuída por Porter, ou seja, crítico às visões que superestimam o papel revolucionário da tecnologia na efetividade militar; aqui, prefere-se inseri tais tecnologias em um contexto maior, condicionado pela forma como a força militar será empregada, pela centralidade da política e pela inevitabilidade do atrito na guerra (BIDDLE, 2004; CLAUSEWITZ, 2007).

Do ponto de vista metodológico, este é um artigo interpretativo que se baseia na análise crítica da literatura acadêmica e técnica, bem como de documentos oficiais. Para a crítica do conceito de CPGS, primeiramente faremos a análise das premissas que o embasam. Em seguida, discutiremos os programas por meio dos quais os sucessivos governos norte-americanos vêm colocando tal conceito em prática. Finalmente, com base na análise conceitual e empírica, podem-se

4 É importante salientar que a crítica de Porter (2015) não se assemelha em nada com a retórica nacionalista e xenófoba do presidente Donald Trump. Ver também Nye (2002) e Mead (2011). 
inferir os riscos que essas iniciativas trariam para a paz e o equilíbrio no sistema internacional. Ao cabo, espera-se contribuir teoricamente para uma correção das perspectivas realistas que supõem acriticamente que os Estados Unidos se comportam como potência defensora do status quo no sistema internacional.

\section{Multipolaridade desequilibrada, poder terrestre e projeção de força}

As interações de segurança entre os atores no sistema internacional, incluindo as capacidades e intenções de projeção de força, são condicionadas pela estrutura resultante da distribuição de poder previamente estabelecida entre eles. Os mais capazes dentre eles são chamados de polos de poder.

Para a condição de polo, portanto, mesmo na assim chamada Era Digital, que caracteriza o alcance mundial do capitalismo, o poder militar ainda é central (CEPIK, 2013). O status de grande potência, nesse sentido, pode ser definido a partir de três características: 1) da capacidade de retaliação frente a um ataque nuclear (capacidade de segundo ataque); 2) do comando do espaço, entendido como "a capacidade de um país garantir por meios próprios o seu acesso e uso do espaço em tempos de paz e de guerra, bem como a habilidade de impedir um adversário de lhe negar tal proveito" (CEPIK, MACHADO, 2011, p. 114); e, finalmente, 3) da inexpugnabilidade. Essa última é definida pela existência de capacidades convencionais suficientes para tornar "impossível para qualquer outro país sustentar uma invasão territorial e a derrocada da soberania do Estado" (CEPIK, 2013, p. 311).

Com base nos três critérios considerados necessários e suficientes, considera-se o sistema internacional atual como tendo três polos: Rússia, China e Estados Unidos. A despeito da estrutura multipolar, no entanto, há notadamente uma assimetria entre os polos, especialmente devido à preponderância militar e econômica dos Estados Unidos, assim como sua condição geográfica (MEARSHEIMER, 2007). Já China e Rússia vêm de posições distintas, a primeira está em um caminho de ascensão, enquanto que a segunda luta para reverter uma tendência de declínio relativo. Dentre as potências regionais existentes, a Índia é o único Estado que se encontra em processo consistente de se tornar uma grande potência (PARDESI, 2015).

Assim, a polaridade atual configura-se como multipolar e desequilibrada (a favor dos Estados Unidos). Essa conformação da estrutura do sistema, conforme 
Mearsheimer (2007) argumenta, é comparativamente mais instável do que as outras configurações. Nesse cenário, a tendência é que a polarização seja elevada, na medida em que há fortes incentivos para que os polos adotem posturas de balanceamento ou alinhamento, motivadas por visões revisionistas, ou buscando manter o status quo, ou sendo revisionistas exatamente para manter o status quo (MEARSHEIMER, 2007).

Nesse sentido, a interação entre os polos, principalmente em sua faceta militar, é sintomática desses condicionantes estruturais. Mearsheimer (2007), em sua definição de poder militar, defende duas ideias fundamentais para discussão sobre a projeção de força dos atores e a capacidade de vencer as distâncias 5 . A primeira diz respeito às linhas interiores: o poder terrestre é considerado por ele como a forma dominante de poder militar, uma vez que "o poder de um Estado está fundamentalmente firmado no seu exército e nas forças aéreas e navais que apoiam essas forças terrestres” (MEARSHEIMER, 2007, p. 93). Essa posição se justifica pelo fato do poder terrestre ser central para conquista e domínio de território - o objetivo político supremo num mundo de Estados territoriais (MEARSHEIMER, 2007). Já a segunda diz respeito às linhas exteriores: o autor credita às grandes massas de águas o poder de limitar fortemente as capacidades de projeção de poder das forças terrestres, chamando essa condição de "poder parador da água” (MEARSHEIMER, 2007, p. 93-142). Esse seria o fator principal a impedir a existência de um ator hegemônico global internacional: por maior, mais bem treinado e equipado que seja um exército, sua capacidade de se projetar globalmente é limitada pelo poder parador da água (MEARSHEIMER, 2007).

A projeção de poder militar, dessa perspectiva, não se sustentaria sem o poder terrestre, sendo incapaz de efetivamente obter a vitória na guerra por si só.

No entanto, como argumentam Pape (1996) e Biddle (2004), percebe-se, cada vez mais, o surgimento de interpretações que buscam contestar a centralidade do poder terrestre na guerra contemporânea. Essas teorias são, na maioria das vezes, centradas no papel revolucionário que a tecnologia tem sobre conflitos militares.

5 Projeção de força, segundo a própria definição do Pentágono, é "a habilidade de projetar instrumentos militares do poder nacional a partir do país de origem ou de outro teatro, em resposta aos requerimentos das operações militares" (DEPARTMENT OF DEFENSE, 2014, p. 99). A forma mais convencional de projeção de força é através dos meios marítimos, especialmente pela sua grande capacidade de tonelagem. Nesse sentido, projeção de poder marítimo é a projeção de força no ambiente marítimo e a partir dele, incluindo um amplo espectro de operações militares ofensivas, buscando destruir as forças inimigas ou seu apoio logístico ou ainda evitar que ele se aproxime o bastante para ameaçar as forças aliadas (TILL, 2012, p. 133; DEPARTMENT OF DEFENSE, 2014, p. 163). 
Creem, nesse sentido, que o aumento da letalidade e da precisão sem precedentes, bem como o aumento do alcance dos ataques aéreos por meio de mísseis ou aeronaves furtivas, tornou a natureza da guerra extremamente dinâmica, onde os conceitos clássicos de atrito e fricção perderam espaço para a mobilidade, para os ataques aéreos em profundidade e para a guerra de informação (BOOT, 2003).

Essa visão se fortaleceu após a Guerra do Golfo (1991), baseando-se a interpretação de que a vitória foi atingida graças apenas à superioridade tecnológica. A ideia de Revolução em Assuntos Militares (RMA), nesse sentido, cresceu e, em 2003, gerou o que Max Boot (2003) chamou de "Novo Modo Americano de Fazer a Guerra", que se baseia na supremacia da tecnologia e do poder aéreo sobre a massa (manpower). Desde então, a RMA se converteu em uma espécie de senso comum em diversas análises da segurança internacional (BIDDLE, 2004) ${ }^{6}$.

Essencial, diante disso, é destacar a visão característica da RMA7 ${ }^{7}$ sobre o poder aéreo, uma vez que o mesmo é visto como o elemento central da superioridade militar estadunidense por seus defensores. Mais que isso, segundo a crítica de Robert Pape (1996), essa visão passou a reconhecer o poder aéreo, a partir da evolução tecnológica, central não só na vitória militar, mas também como o centro da coerção estatal. Dessa perspectiva, o mais importante em uma operação militar é que o poder aéreo seja capaz de destruir as principais fontes de poder de um Estado (ou, em alguns casos, eliminar a liderança política) para que o mesmo seja derrotado. O papel do poder terrestre, nesse sentido, seria apenas o de ocupar território ou lidar com forças residuais inimigas após a ofensiva aérea.

Dessa visão, decorrem algumas propostas normativas importantes e que perpassam o objeto de análise das seções seguintes. Como referência ideológica está a ideia de globalismo. Essa, uma ideia mais ampla e que se baseia nas condições operacionais da RMA, deriva do pensamento de que a tecnologia encurtou as distâncias de maneira tão significativa que comprimiu estrategicamente o espaço entre os Estados. Nesse contexto, a violência poderia ser mais facilmente exportada. $\mathrm{O}$ tradicional caráter protetor das grandes distâncias foi superado, a guerra ofensiva

6 Devemos destacar que a evolução tecnológica enquanto principal fator em evolução no debate sobre eficiência militar tem como base um leque diverso de esforços teóricos e de evidências. Esse é o caso de alguns conceitos como o de guerra centrada em rede (Network-centric Warfare), de munições guiadas de precisão (PGM) e dos efeitos que isso gera nas operações militares, demandando uma perspectiva integrada no planejamento e na condução das campanhas e batalhas (Jointness). O que se contesta aqui é o caráter revolucionário dessas evoluções técnicas, na medida em que não há evidências de uma mudança nas dinâmicas elementares da guerra, como a preponderância da defesa sobre o ataque, da centralidade do modo de empregar a força e da importância do poder terrestre e da massa (CLAUSEWITZ, 2007; BIDDLE, 2004; MEARSHEIMER, 2007; PORTER, 2015).

7 Essa perspectiva tem como base os trabalhos do coronel aposentado da Força Aérea dos EUA John Warden III. 
foi exponencialmente fortalecida, enquanto a guerra defensiva foi enfraquecida ao ponto de não poder mais contar com a proteção geográfica (PORTER, 2015), ou, nos termos de Mearsheimer (2007), com o poder parador da água.

Podem ser identificados, nesse sentido, dois tipos de visões prescritivas como consequência dessa crença globalista. A primeira acredita que esse ambiente comprimido demanda uma postura mais agressiva baseada no interesse próprio, onde os Estados devem tomar ações mais radicais e se manter em constante estado de emergência a fim de se manterem seguros. A segunda, por sua vez, tende a uma postura mais cosmopolita em sua visão da ordem mundial. Ambas, no entanto, assumem que a proximidade e interdependência dos países os tornam crescentemente vulneráveis. Além disso, fala-se em uma ordem mundial repleta de Estados cada vez mais frágeis, onde as ameaças transnacionais e a alta volatilidade do sistema demandam uma postura mais internacionalista e abrangente do que uma mais restritiva por parte dos Estados Unidos (PORTER, 2015).

Essa demanda por presença global, no entanto, não surgiu apenas recentemente. Segundo Silverstone (2014), o acesso global irrestrito vem sendo um dos principais objetivos estratégicos dos EUA pelo menos nos últimos 100 anos. Operacionalmente, Barry Posen (2003) explicou essa condição pelo "comando dos comuns": em síntese, os EUA detinham o controle das rotas oceânicas, do espaço aéreo acima de $5.000 \mathrm{~m}$ e do espaço sideral. Isso garantia a capacidade de projeção de força global, simbolizada pela utilização constante dos porta-aviões e de seu grupo de batalha como instrumentos de dissuasão. Um exemplo que ilustra essa prática é o caso da Crise dos Estreitos de 1996 entre China e Taiwan, encerrada apenas após Washington enviar dois porta-aviões para a região.

No entanto, desde o começo dos anos 2000, houve uma erosão da posição relativa dos Estados Unidos no sistema internacional (VISENTINI, 2005) ${ }^{8}$. Em primeiro lugar, houve os fracassos militares no Afeganistão e no Iraque (CORDESMAN, 2007). Em segundo, a crise global iniciada em 2008 - mesmo que seguida de uma reação americana sob a presidência de Obama - evidenciou os limites de um modelo de governança econômica global baseado na desregulamentação e na concentração excessiva de riquezas. Finalmente, desde a guerra da Geórgia em 2008, houve um tensionamento crescente entre a Rússia e os Estados Unidos, culminando nas guerras híbridas da Ucrânia e da Síria.

8 Obviamente, o alcance e a duração do declínio da posição relativa dos Estados Unidos constituem um dos temas mais polêmicos nas relações internacionais. Para uma perspectiva contrária da defendida aqui, ver, dentre outros, Valladão (1995), Fiori, Serrano e Medeiros (2008), Duarte (2013) e Brooks e Wohlforth (2016). 
O caso da China, distinto da Rússia, foi ainda mais importante para a mudança relativa na distribuição do poder e da riqueza no mundo contemporâneo. Ao se inserir na era da digitalização, o país desenvolveu sistemas defensivos robustos para fazer frente às ameaças externas vindas de atores relativamente mais poderosos. Sua condição de inexpugnabilidade militar, por exemplo, materializa-se em uma rede complexa de sistemas redundantes e complementares. Eles vão desde os mais simples mísseis antiaéreos (SAMs), minas marítimas, elevada quantidade de mísseis antinavio capazes de saturar qualquer defesa de ponto na vizinhança, até os que envolvem tecnologias antissatélite (ASAT), minas inteligentes, mísseis balísticos antinavio (DF-21D) e caças de última geração (TOL, 2010). Além disso, o país construiu uma extensa rede de túneis subterrâneos modernos, alegadamente capaz de fornecer abrigo aos seus sistemas estratégicos e garantir ao país a capacidade de segundo ataque nuclear (KARBER, 2011)99.

Nesse contexto, um dos projetos mais simbólicos que objetivavam retomar a liderança global por parte dos EUA foi o do ataque global imediato ou apenas Global Strike. Como se verá na seção seguinte, o projeto é, em suma, baseado na ideia de entregar ogivas convencionais em qualquer lugar do mundo em no máximo uma hora após ordenado pelo presidente. Se, por um lado, a justificativa imediata tenha sido as ameaças impostas pelo terrorismo, no contexto da Guerra ao Terror, ou pelos Estados do "eixo do mal”, logo ficou evidente que os sistemas buscavam também lidar com a ascensão de novos polos no sistema internacional.

Nesse sentido, percebe-se mais uma vez a retomada da crença no poder aéreo, nesse caso mesmo através de mísseis baseados em terra ou no mar, como uma espécie de "bala de prata" capaz de neutralizar as ameaças de forma instantânea. O globalismo dificilmente pode ser representado de forma melhor do que o é pelo projeto do Global Strike: coerção global à pronta disposição do presidente com o atraso de apenas uma hora de voo. A análise do projeto, de sua estrutura e dos sistemas que o compõe parece ser importante, portanto, para a compreensão da forma como se dará a conformação dos novos polos do sistema internacional pela grande potência situacional em uma nova ordem mundial.

9 Os Estados Unidos interpretaram a modernização militar chinesa como um meio de estabelecer uma zona de influência no Leste e Sudeste Asiático. Nessa região, a China supostamente teria a capacidade de contestar não apenas a livre circulação dos bens globais nas linhas marítimas mais movimentadas do mundo em termos de comercio internacional, mas também impedir o próprio acesso operacional dos Estados Unidos à região. Isso, sustentado pelos sistemas de armas citados acima, seria a essência do que ficou conhecido como capacidades de Antiacesso e de Negação de Área (A2/AD). 


\section{O Conceito de Ataque Global Imediato (CPGS) e seus programas}

A técnica de pesquisa utilizada para esta seção foi a análise de conteúdo de dois importantes relatórios. O primeiro é um trabalho realizado por James Acton em 2013 para o Carnegie Endowment for International Peace. O trabalho é relevante, pois amplia e sistematiza dados que não são facilmente disponíveis, bem como avança na especificação dos modelos (ACTON, 2013). O segundo relatório, mais institucional, foi produzido em 2016 pela equipe do Congressional Research Service dos Estados Unidos. Divulgado anualmente, o trabalho coordenado por Amy Woolf (2016) é informativo e baseia-se em fontes pouco acessíveis para outros analistas. Por outro lado, é muito descritivo e pouco analítico.

O objetivo central perseguido por meio do conceito de ataque global imediato é desenvolver a capacidade de atacar, de forma convencional e sem depender de bases avançadas, alvos em qualquer lugar da terra em até uma hora (WOOLF, 2016, p. 2). No entanto, como destaca Acton (2013, p. 4), não há uma definição sintética e consolidada sobre o conceito: atualmente, tanto a marca de uma hora quanto o alcance global parecem ser mais uma diretriz base do que uma regra. Nesse sentido, a literatura especializada costuma tratar de tais capacidades como sistemas convencionais de longo alcance e velocidade hipersônica; nominalmente, capacidades de Conventional Prompt Global Strike (CPGS) (ACTON, 2013, p. 5). Por velocidade hipersônica, refere-se às velocidades de Mach 5 ou acima ${ }^{10}$; longo alcance, por sua vez, corresponde a pelo menos $1.500 \mathrm{~km}^{11}$.

Embora já se reconheça a utilidade do emprego de tais capacidades há pelo menos 40 anos (GORMLEY, 2015), a ideia de ataque global imediato foi tomar um significado mais sólido apenas no início da década de 2000 (WOOLF, 2016). A necessidade de desenvolver sistemas convencionais de alta prontidão e alcance global foi explicitada em documentos estratégicos dos Estados Unidos, como nos Relatórios de Revisão Quadrienal de Defesa de 2001, 2006 e 2010, a fim de atacar com precisão alvos móveis ou fixos, enterrados e/ou protegidos (WOOLF, 2016, p. 3).

A principal vantagem desse tipo de sistema reside, alegadamente, na criação dos meios para se exercer poder coercitivo de forma global, imediata e unilateral sem romper o limiar nuclear. Para isso, em comparação com os mísseis balísticos

10 Como se sabe, Mach 5 equivale a cinco vezes a velocidade do som, ou $6.174 \mathrm{~km} / \mathrm{h}$.

11 Por esse motivo, incluem-se aqui também os mísseis cruzadores hipersônicos (desde que de longo alcance). 
atuais armados com ogivas nucleares, no entanto, importantes avanços técnicos devem ser assimilados. Nos mísseis balísticos, o desafio central está relacionado à precisão e à manobrabilidade. Como base de comparação, o míssil balístico de longo alcance mais preciso é o estadunidense UGM-133 Trident II, lançado de submarino, tendo um erro circular provável (CEP) ${ }^{12}$ de aproximadamente $120 \mathrm{~m}$ (GLOBAL SECURITY, 2011). Como o rendimento de uma ogiva convencional é ínfimo perto de uma ogiva nuclear, estima-se que, para cumprir a função de destruir um alvo, um míssil balístico convencional deva ter um CEP de 5 a 10 m (ACTON, 2013, p. 87).

A diferença se dá especialmente pelo fato de que os vetores nucleares atuais de longo alcance têm a guiagem extremamente limitada após a fase de lançamento. Os dois principais fatores a afetarem o CEP são os sistemas de navegação e a manobrabilidade. Então, a melhor maneira de se conseguir a precisão necessária nos mísseis balísticos convencionais é através do uso de veículos de reentrada manobráveis, isto é: equipados com um sistema de navegação e de asas que permitam ao vetor planar e manobrar antes de atingir o solo (ACTON, 2013, p. 35). A opção relativamente mais simples seria adaptar mísseis balísticos para guiagem terminal. No entanto, como a velocidade de reentrada é altíssima (Mach 22), pouco pode ser feito - o CEP dificilmente baixa de $100 \mathrm{~m}$. Uma opção bem mais complexa é a utilização de um veículo planador hipersônico (boost-glide) para carregar as ogivas. Ele é lançado de um míssil balístico e reentra na atmosfera assim que possível, planando até seu alvo final. No entanto, controlar um veículo com velocidade hipersônica de Mach 20 ainda é tecnicamente impraticável. Outra opção, por fim, é utilizar mísseis cruzadores hipersônicos (velocidade Mach 6-8), cuja propulsão se dá em toda a rota. No entanto, embora a velocidade de um míssil cruzador seja substancialmente menor que a de um balístico (em sua reentrada), a propulsão hipersônica ainda não foi dominada e seu alcance é bem mais limitado (ACTON, 2013, p. 52-54).

Segundo analistas, as principais missões onde as capacidades de CPGS podem ser empregadas são: (i) eliminar terroristas de alto valor e desabilitar suas operações; (ii) conter capacidades de Antiacesso e Negação de Área (A2/ AD) capazes de impedir o livre trânsito ou ameaçar capacidades estadunidenses ou de aliados; (iii) destruir ou desabilitar capacidades antissatélite (ASAT); e (iv) negar a um estado hostil a capacidade de utilizar seu arsenal nuclear (ACTON, 2013, p. 26; SUGDEN, 2009, p. 116; WOOLF, 2016, p. 6-8).

12 Da mesma forma, vale lembrar que CEP (Circular Error Problable) é uma medida de precisão de mísseis, dada pelo raio do círculo de um alvo que cada tipo de míssil provavelmente atingirá. 
A primeira, a partir do 11 de setembro de 2001, serviu como mote principal para justificar a inclusão do conceito nos documentos oficiais dos Estados Unidos (WOOLF, 2016). A segunda, por sua vez, é justificada pela crescente proliferação de sistemas capazes de negar aos EUA a supremacia sobre os comuns globais e seu acesso a regiões consideradas como estratégicas para a segurança nacional (inclusive, energética), principalmente o Leste e o Golfo Pérsico (POSEN, 2003; SILVERSTONE, 2014; TOL, 2010). Aqui, o terceiro ponto também se inclui, na medida que visa sustentar o comando do espaço por parte dos EUA. Por fim, o quarto está relacionado às tentativas de nuclearização de alguns Estados considerados como ameaças, como Coreia do Norte e Irã (NATIONAL RESEARCH COUNCIL, 2008).

No entanto, embora todas essas missões sejam sugeridas por alguns defensores do conceito, incluindo documentos oficias das Forças Armadas, Acton (2013, p. 13) destaca que nunca houve, de fato, uma explicitação das missões dos sistemas de CPGS a nível doutrinário. Tanto no governo Bush quanto no governo Obama, tem-se falado apenas de maneira genérica sobre a necessidade de desabilitar, em período de tempo curtíssimo, alvos móveis e fugazes em áreas bem defendidas e distantes (ACTON, 2013, p. 15).

Para além das dificuldades naturais de debater essas questões complexas com a sociedade, nota-se, desde o início, que isso é resultado de uma opção por um planejamento baseado em capacidades e não em cenários (ACTON, 2013, p. 21). Ou seja, há pouca integração entre o desenvolvimento dos sistemas e os objetivos estratégicos e as missões operacionais delineadas no planejamento de alto nível ${ }^{13}$. Essa opção está relacionada à própria falta de uma grande estratégia clara por parte dos EUA na última década (SILVERSTONE, 2014; POSEN, 2015, SILOVE, 2017). Nesse sentido, esse tipo de planejamento é problemático por dois motivos. Primeiro, ignora a diferença das requisições técnicas que cada missão exige e as opções políticas que decorrem disso (necessidade ou de preempção ou de prontidão para retaliação ${ }^{14}$ ). Segundo, desconsidera as características tecnológicas

13 Foge ao escopo deste artigo a análise crítica das diferenças, incluindo vantagens e desvantagens entre as metodologias de planejamento de Defesa. Não obstante, assumimos provisoriamente que para ser efetivo e legítimo, esse planejamento precisa combinar fins (hipóteses de emprego, cenários etc.) e meios (capacidades absolutas e relativas, atuais e futuras). Para mais informações sobre esse debate, ver Gaffney (2004) e National Research Council (2005).

14 Por exemplo, as missões voltadas para conter o A2/AD são basicamente preemptivas, uma vez que devem ser levadas a cabo antes que o adversário possa lançar seus sistemas contra os alvos de alto valor. É o caso também das missões antissatélite e contraforça nuclear. Já missões contraterrorismo podem ser feitas de forma retaliatória, uma vez que o adversário não possui grandes defesas capazes de impedir o ataque em qualquer momento. 
das opções potenciais de CPGS: cada uma tem seus prós e seus contras em termos de custo/benefício e isso se reflete no nível de efetividade que cada uma terá em um cenário particular - este, sim, portanto, o seu principal condicionante (ACTON, 2013, p. 25-28).

A primeira confusão se dá em termos de velocidade e relação com a prontidão e com a surpresa tática. Prontidão significa que os sistemas atingirão seus alvos em um período de tempo curtíssimo desde a decisão de lançá-los. Surpresa tática, por sua vez, significa que o ataque não gerará nenhum alerta (ou pouco) antes de atingir o adversário ${ }^{15}$. A velocidade incide obrigatoriamente sobre o primeiro, enquanto que no segundo caso ela pode ser substituída por outros fatores ${ }^{16}$. Embora, em um cenário ideal, fosse relativamente útil que um sistema fornecesse ambos, na prática, isso é excessivamente complexo e, mais importante, para os fins declarados, desnecessário. Isso se dá porque, por um lado, algumas missões simplesmente não exigem prontidão: o caso mais claro disso é o das missões de supressão das defesas aéreas ${ }^{17}$ no A2/AD, por exemplo. Tem-se ainda o exemplo dos ataques preemptivos contra sistemas ASAT ou contra capacidades nucleares. Essas situações não exigem prontidão, mas sim surpresa tática (i.e. preempção), uma vez que provavelmente se dará em um contexto de crise (e.g. contra China ou Irã) e com alto alerta estratégico (ACTON, 2013, p. 22-23). Por outro lado, as missões de contraterrorismo e as que envolvem retaliação (nuclear e ASAT) se beneficiam mais da prontidão ${ }^{18}$ (SUGDEN, 2009; ACTON, 2013). Percebe-se, portanto, que a necessidade do CPGS é mais funcional para missões preemptivas, uma vez que as de retaliação já são cumpridas de forma efetiva com os sistemas nucleares atuais.

Relaciona-se também com a velocidade o nível de penetração defensiva do vetor. Embora seja função da velocidade, também depende da capacidade de resistência à interferência eletrônica (jamming) (ACTON, 2013, p. 24). Nesse sentido, essa preocupação não se justificaria nos casos de contraterrorismo, por exemplo, ou não se justificaria com o mesmo nível de prioridade entre missões pensadas contra Coreia do Norte ou contra a China.

\footnotetext{
15 Surpresa tática difere de surpresa estratégica. Nesse último, não se espera o ataque. Naquele, o ataque até é esperado, porém não se sabe onde, como e nem com quais meios será realizado.

16 Seja na composição do material, no formato do vetor (stealth), na trajetória de abordagem, dentre outros.

17 Segundo definição do Pentágono (DEPARTMENT OF DEFENSE, 2014), a supressão das defesas aérea inimigas (SEAD) consiste na neutralização, destruição ou degradação dos sistemas antiaéreos (mísseis, radares e interceptadores em geral) do adversário através de sistemas de guerra convencional ou eletrônica (DEPARTMENT OF DEFENSE, 2014).
}

18 A surpresa tática, apesar de desejada, não é necessária em casos retaliatórios. 
A questão do alcance também é importante: deve ser pensada tendo como referência a possibilidade ou não de haver alerta estratégico sobre situações de risco. Nas funções citadas acima, nesse sentido, o alcance global só parece ser essencial na questão do contraterrorismo, uma vez que é possivelmente a única situação em que não haverá o alerta estratégico ${ }^{19}$. Nos outros casos, as opções com alcance regional parecem mais eficientes: basta que, assim que iniciada a crise, esses sistemas sejam deslocados para as proximidades do alvo. Além disso, podem amenizar o risco de ser confundido com um ataque nuclear (ACTON, 2013, p. 24).

Nesse sentido, dadas as requisições técnicas diferentes entre as missões, uma abordagem centrada nos cenários poderia, primeiro, tratar de forma mais realista as necessidades técnicas - servindo melhor ao propósito da missão - e, segundo, mitigar a incerteza sobre as missões prioritárias aos olhos dos outros atores do sistema internacional, na medida em que esses terão mais clareza sobre os impactos dos novos sistemas sobre suas próprias capacidades. Ambos procedimentos podem contribuir com a análise do custo/benefício dos sistemas tanto em termos táticos e técnicos quanto em termos políticos, o que será tratado nas próximas seções; no entanto, primeiro se faz necessário uma análise sobre o que já vem sendo feito no âmbito do CPGS.

Quando analisamos o histórico dos programas, percebe-se que as primeiras tentativas no sentido de tornar operacional o ataque global imediato deram-se na metade dos anos 2000, quando a administração Bush sugeriu que ogivas convencionais fossem adaptadas para os mísseis Trident II embarcados em submarinos estratégicos (WOOLF, 2016, p. 10). No entanto, essa proposta logo foi recusada pelo Congresso, a fim evitar a "ambiguidade nuclear", ou seja, que algum país confundisse o lançamento convencional com o nuclear, uma vez que o vetor seria o mesmo (GORMLEY, 2015).

Atualmente, identifica-se até cinco sistemas diferentes de CPGS em consideração pelos EUA; são divididos entre as três categorias apresentadas no início da seção (balístico com guiagem terminal, boost-glide e cruzador hipersônico). No primeiro caso, tem-se o Conventional Strike Missile (CSM) e o Sea-Launched Intermediate-Range Ballistic Missile (SLIRBM). Embora temporariamente paralisado,

19 No restante das funções, é altamente provável que os EUA já possuam informações suficientes para alerta estratégico antes da decisão de realizar a missão. Por exemplo, caso exista a possibilidade de uma ofensiva sobre as capacidades de $\mathrm{A} 2 / \mathrm{AD}$, ela se dará certamente em contexto de crise internacional. 
o CSM está sob o comando da Força Aérea e é um vetor baseado em terra (nos EUA), planejado para utilizar ogivas planadoras a fim de evitar as trajetórias balísticas ou desviar de países neutros e garantir a precisão adequada (WOOLF, 2016). O míssil teria capacidade de carregar $1.500 \mathrm{~kg}$ em ogivas, um alcance intercontinental maior que $17.000 \mathrm{~km}$ e teria como veículo de reentrada o HTV-2 (apresentado abaixo) ou semelhante (ACTON, 2013, p. 44). Já a ideia do SLIRBM surgiu em 2003, porém em 2008 saiu de prioridade, voltando apenas em 2012 no contexto das futuras necessidades no seu uso na região da Ásia-Pacifico (WOOLF, 2016). Parece ser a opção mais simples tecnicamente, uma vez que é um míssil balístico de alcance intermediário ${ }^{20}(2.400-3.700 \mathrm{~km})$ com guiagem terminal e, a princípio, baseado em submarino da classe Virginia - é capaz de carregar até $700 \mathrm{~kg}$ (ACTON, 2013, p. 44). Por um lado, esse conceito menos complexo compromete a sua precisão e diminui, portanto, sua efetividade contra alvos menores ou melhor protegidos (como em silos ou bem enterrados); por outro lado, sua trajetória balística pode contribuir com a “ambiguidade nuclear” e gerar instabilidade regional. Outro fator a ser levado em conta é que, provavelmente, ele seria encaixado nas proibições do New-START21.

No segundo caso, há dois projetos decisivos, o Hypersonic Test Vehicle no. 2 (HTV-2) e o Advanced Hypersonic Weapon (AHW). O primeiro é um projeto liderado pela Lockheed Martin e patrocinado pela Agência de Pesquisa em Projetos Avançados de Defesa (DARPA), inicialmente pensado para ter um alcance de $17.000 \mathrm{~km}$, porém já modificado para um alcance menos ambicioso de 6.000 $\mathrm{km}$. A ideia é que o HTV-2 seja baseado em terra, lançado de um míssil balístico e com velocidades de até Mach 20. Dois testes já foram realizados (em 2010 e 2011), porém ambos falharam com o projétil destruindo-se (GORMLEY, 2015). Paralelamente, dadas as dificuldades com o HTV-2, surgiu o AHW, um projeto do Exército com a DARPA, consistindo basicamente em um protótipo semelhante ao HTV, porém também com alcance reduzido $(8.000 \mathrm{~km})$. O primeiro teste foi realizado em 2011 e foi bem-sucedido, onde o AHW foi controlado e atingiu o alvo com sucesso depois de $4.000 \mathrm{~km}$. Desde então, é o projeto prioritário dentro do CPGS, recebendo boa parte dos recursos destinados ao programa, inclusive com

20 No entanto, também se cogita utilizar um veículo de reentrada planador (possivelmente o AHW, também explicado em seguida) ao invés de um mero veículo com guiagem terminal. Essa modificação, entretanto, por um lado melhoraria a precisão, mas, por outro, tornaria o sistema ainda mais complexo e fora da realidade atual.

21 O Novo Tratado de Redução de Armas Estratégicas (New-START) foi assinado em 2010 entre Rússia e EUA, onde ambos se comprometeram a reduzir o número de ogivas e mísseis com trajetória balística pela metade. 
planos de instalação tanto em terra (em bases avançadas como Guam e Diego Garcia), quanto em vasos de superfície ou submarinos (ACTON, 2013, p. 42). No entanto, o projétil falhou no último teste em 2014, explodindo quatro segundos após o lançamento. Apesar disso, novos testes já foram aprovados no orçamento de 2016 e serão realizados em 2017 e 2020 (GORMLEY, 2015).

Já a última categoria, o caso dos mísseis cruzadores hipersônicos, é uma abordagem alternativa dentro do CPGS, uma vez que tem o alcance mais limitado (no máximo $1.500 \mathrm{~km}$ )22. Diferentemente dos mísseis balísticos, os mísseis cruzadores têm a sua velocidade inteiramente provida pela sua turbina. O controle de turbinas hipersônicas, no entanto, ainda é extremamente difícil e instável. Alguns testes nesse sentido vêm sendo realizados nos últimos anos com uma taxa de sucesso ainda não satisfatória ( $50 \%$ em média), caso do projeto X-51A WaveRider que, nos testes bem-sucedidos, atingiu a velocidade de Mach 5. Em 2012 a Força Aérea anunciou planos para desenvolver um míssil cruzador baseado nessas turbinas hipersônicas, chamado de High Speed Strike Weapon (HSSW). A grande vantagem dos mísseis cruzadores é a capacidade de manobrabilidade, o que permite uma maior precisão, menor risco de "ambiguidade nuclear”, menor detecção por parte dos radares do adversário (seja pela possibilidade de voar abaixo dos radares inimigos quanto pela manobrabilidade) e não demandaria a saída da atmosfera. Embora as melhores estimativas apontem a metade da década que vem para sua capacidade operacional, não há um prazo confiável para isso, ficando muito à sorte do sucesso dos próximos testes do protótipo X-51 WaveRider (ACTON, 2013, p. 52-53).

Portanto, percebe-se que cada tipo de sistema possui sua individualidade, gerando não apenas demandas técnicas próprias, mas também diferentes resultados conforme as características da missão e seu contexto político. Além disso, diferemse em termos de complexidade, havendo uma relação inversa entre complexidade e aceitação política: os menos complexos, como os mísseis balísticos com guiagem terminal (SLIRBM e a primeira versão do CSM), tendem a gerar mais polêmica na medida em que são semelhantes ao que já se tem (nucleares); já os de complexidade maior, como os baseados em mísseis balísticos com planadores hipersônicos (AHW, HTV-2 ou a última versão do CSM) ou os mísseis cruzadores hipersônicos, tendem a ter maior aceitação política tanto dentro dos EUA quanto

22 Estão inclusive burocraticamente sob a guarda do Comando de Combate Aéreo, que é responsável pelos sistemas táticos, e não do Comando de Ataque Global da Força Aérea, responsável pelo CPGS (ACTON, 2013). 
dos seus aliados e, por isso, recebem maiores recursos quando bem avaliados tecnicamente (AHW e HSSW).

No entanto, é importante reiterar a importância de se abordar o tema a partir das missões e não dos sistemas. Acima de tudo, é a capacidade dos sistemas em cumprirem as missões planejadas que incide sobre o nível da estratégia e que gera resultados sobre a polarização ou, até mesmo, sobre a polaridade internacional caso da condição de inexpugnabilidade ou da capacidade de segundo ataque. Isso será abordado em seguida, antes, porém, devemos conectar os sistemas táticos com as suas missões operacionais a fim de entender para qual direção o CPGS está indo de fato e quais são as suas prioridades reais.

Nesse sentido, a capacidade de se realizar a missão depende não apenas do sistema em si, mas também do ambiente operacional em que ele será utilizado especialmente sobre quais sistemas ele pretende se sobrepor e quais contramedidas serão enfrentadas. Países melhor equipados são muito mais difíceis de serem surpreendidos taticamente, uma vez que possuem sistemas de alerta antecipado robustos, como é o caso da Rússia e, em menor medida, da China (ACTON, 2013; WEEDEN, CEFOLA, SANKARAN, 2010). Em termos de surpresa tática, então, os mísseis cruzadores hipersônicos seriam a melhor opção, como já exposto. No entanto, se considerarmos a sobrevivência frente às defensas antiaéreas mais avançadas, a melhor opção seriam os sistemas mais velozes e com menor dependência eletrônica, caso dos mísseis balísticos clássicos ${ }^{23}$. Os com guiagem terminal já são mais vulneráveis a jamming, já que dependem de sistema de navegação; os baseados em boost-glide, por sua vez, são ainda mais dependentes de navegação, inclusive no meio curso (BURNS, 2010).

Por conseguinte, qualquer que seja o sistema escolhido, só conseguirá atingir alvos móveis se estiver devidamente inserido em um ambiente coberto por outros sistemas de reconhecimento (drones e satélites) capazes de enviar dados essenciais para sustentar uma rede informacional confiável (ACTON, 2013, p. 71). Nesse caso, para missões contraterrorismo, por exemplo, é mais fácil e mais barato utilizar os próprios drones para atacar os alvos. Nas outras missões, os sistemas de inteligência podem comprometer, em alguma medida, a surpresa tática, por isso a importância de se ter aliados regionais ou algum tipo de força avançada.

Contra alvos subterrâneos ou bem protegidos, por sua vez, percebe-se que a capacidade de penetração dos sistemas desenvolvidos com base no CPGS seria

23 Para mais informações sobre defesa contra antibalísticos, ver Simionato, Baptista e Ferrazza (2015). 
limitada ${ }^{24}$, por mais que a precisão ideal seja atingida (ZHAO, 2011). Afinal, a penetração depende não apenas da velocidade, mas também da ogiva explosiva e, portanto, do tamanho do míssil - o que é limitado, uma vez que põe em risco a capacidade de sobreviver às defesas antiaéreas adversárias e de surpreender o inimigo.

Nesse sentido, se contrastarmos as demandas de cada missão, anteriormente explicitadas (principalmente em termos de prontidão vs. surpresa tática), com as capacidades propostas para os sistemas que recebem os maiores recursos, fica evidente uma preferência pela surpresa tática em detrimento da prontidão (vide AHW e HSSW). Isso significa que as missões mais prováveis no caso de implementação do CPGS, seriam o (1) ataque preemptivo contra força nuclear, (2) o ataque preemptivo contra sistemas ASAT e a (3) supressão de defesas antiaéreas. Por sua vez, as missões de caráter retaliatório ou contraterrorismo continuam a ser cumpridas pelos sistemas já existentes, desde mísseis balísticos nucleares até drones, passando por mísseis cruzadores subsônicos.

Ou seja, há uma clara inconsistência entre as justificativas públicas para o CPGS e seus usos mais prováveis. Afinal, os Estados Unidos contam com alternativas críveis para as missões de retaliação, as quais são utilizadas como justificativa para os investimentos no CPGS desde seus primórdios. Entretanto, sabe-se que a possibilidade de obter surpresa tática está cada vez mais comprometida pelas capacidades dos modernos sistemas de radares. Mesmo as aeronaves e mísseis stealth enfrentariam sérias dificuldades em surpreender um adversário dotado de sistemas de radares e mísseis antiaéreos de média capacidade (KOPP, 2009)25. Eis porque, na prática e contrariando o discurso oficial, o desenvolvimento dos

24 Atualmente, as ogivas de penetração convencional conseguem, em média, chegar a uma profundidade de $10 \mathrm{~m}$ em concreto endurecido. Após isso, o raio da explosão (e sua capacidade de desabilitar os sistemas protegidos) depende do potencial explosivo da ogiva. Nos sistemas CPGS, a força cinética criada por um impacto a velocidades hipersônicas (Mach 22 para mísseis balísticos) é muito superior às das ogivas convencionais, no entanto, isso ocorre, pelo menos atualmente, em detrimento de uma ogiva explosiva capaz de efetivamente explodir após a penetração. Mesmo considerando que, em breve, fosse desenvolvido um material capaz de proteger a ogiva do impacto inicial, a penetração aumentaria no máximo em 3 vezes, ou seja, para um alcance de $30 \mathrm{~m}$. No entanto, o potencial explosivo da ogiva após a penetração ainda estaria limitado pelo rendimento da ogiva e pelo pouco espaço físico disponível para armazenamento no míssil, não acontecendo aumento substancial na área destruída (ZHAO, 2011). Como base de referência, os mais de $5.000 \mathrm{~km}$ de túneis subterrâneos da China ou mesmo os do Irã (embora mais precários) estão localizados a centenas de metros de profundidade (KARBER, 2011).

25 Diversos estudos põem em questionamento a efetividade de penetração de aeronaves stealth, demostrando, por exemplo, que a utilização de radares de banda VHF levemente modificados da década de 1950 podem colocar em cheque o seu uso, como o caso do F-117A derrubado sobre a Sérvia em 1999. Além disso, parece bastante evidente que, pelo menos, China e Rússia não tenham grandes dificuldades em detectar os modernos caças stealth, especialmente o projeto mais caro da história dos EUA, o F-35 (KOPP, 2009). 
projetos associados ao conceito de CPGS possui foco em missões contra sistemas A2/AD. Primeiro, para desabilitar radares e sistemas ASAT que, embora móveis, tenderiam a estar fora de silos protegidos por concreto endurecido e de túneis. Segundo, para suprimir defesas aéreas e criar vias de abordagem segura para a projeção de força ao interior do território adversário.

\section{Riscos estratégicos e políticos}

A crítica padrão ao CPGS tem como foco o problema da ambiguidade nuclear (NATIONAL RESOURCE COUNCIL, 2008). Na verdade, há pelo menos quatro tipos de ameaças geradas ou potencializadas pelo CPGS: (i) ambiguidade nuclear; (ii) ambiguidade de destino; (iii) ambiguidade de alvo; (iv) instabilidade em crises (ACTON, 2013; SAALMAN, 2014; WOOLF, 2016).

A ambiguidade nuclear (i) consiste, então, no risco de se identificar um ataque convencional de forma equivocada, acreditando-se que o míssil balístico esteja munido de ogivas nucleares. Ainda na fase de lançamento, antes do míssil balístico sair da atmosfera, por exemplo, o sistema de satélites de alerta antecipado da Rússia poderia reconhecer o foguete de propulsão como sendo um ICBM. Em tal cenário, imediatamente seriam acionados mecanismos de retaliação nuclear por parte dos russos, com resultados potencialmente catastróficos. Como já foi mencionado, esse tipo de risco foi discutido desde o início do debate sobre CPGS. Como resultado, o governo americano decidiu não adotar as soluções mais simples tecnicamente, tais como a utilização de mísseis balísticos que hoje carregam ogivas nucleares para a função de ataque convencional (WOOLF, 2016). Entretanto, como apenas Rússia e Estados Unidos possuem atualmente sistemas de alerta antecipado de alcance efetivamente global e, desde a Guerra Fria, ocorreram diversos testes com mísseis balísticos sem graves incidentes, a crítica padrão ao CPGS tende a circunscrever os riscos para a segurança internacional à questão da ambiguidade nuclear. Essa interpretação, além de parcial, é perigosa por duas razões. Primeiro, desconsidera que outros países, especialmente a China, procuram desenvolver capacidade de alerta antecipado global (CEPIK, MACHADO, 2011; WEEDEN, CEFOLA, SANKARAN, 2010). Segundo, ela faz crer que a mera adoção de alguma opção com trajetória não balística dentro do CPGS resolveria o problema e não geraria risco de instabilidade. 
Persiste, porém, o problema da ambiguidade de destino (ii), uma vez que trajetórias não balísticas são também menos previsíveis. Seja com ogivas hipersônicas planadoras, ou mesmo mísseis cruzadores hipersônicos, há possibilidade de que um estado interprete incorretamente um lançamento como ameaçador, por mais que o destino declarado seja um terceiro país (ACTON, 2013, p. 126). Esse seria o caso, por exemplo, se um ataque americano contra a Coréia do Norte fosse interpretado por Pequim como um ataque contra a China.

Mesmo que não haja ambiguidade acerca do país destinatário do ataque, ainda assim existe o problema da chamada ambiguidade de alvo (iii). Qualquer ataque com base no conceito CPGS contra uma potência nuclear tende a embutir o risco de que o país destinatário identifique tal ataque como sendo uma tentativa de neutralizar suas capacidades nucleares dissuasórias. Nesse caso, o país alvo teria incentivos para disparar suas armas nucleares estratégicas antes que as mesmas fossem destruídas (MARTINS, CEPIK, 2014).

Finalmente, os defensores do CPGS ignoram o problema da instabilidade em crises (iv). Tal risco é dado pela soma da conjunção dos diversos problemas anteriormente destacados com um contexto político de alta polarização e incerteza (ACTON, 2013, p. 129). Nesse caso, a utilização do CPGS poderia levar à escalada nuclear. No caso da China, por exemplo, uma vez que o esforço principal do CPGS é para desabilitar os sistemas A2/AD de forma preemptiva, importa destacar que os mesmos sistemas de comando e controle (C2) que sustentam o A2/AD vertebram as capacidades de segundo ataque nuclear do país, sob o comando da Força de Foguetes da China (até recentemente chamada de Segunda Artilharia) (HAMMES, 2012). Em caso de crise, haveria incentivos para a China antecipar-se aos ataques preemptivos dos EUA, adotando uma postura agressiva e escalando o conflito para defender seus sistemas de C2 mais vitais.

Por tudo isso, o CPGS tende a ser visto como um polêmico complemento do Escudo Antimíssil na Europa e na Ásia. Nesse sentido, o CPGS seria a lança de um esforço estadunidense para obter a primazia nuclear (SAALMAN, 2014; LIEBER, PRESS, 2006) ${ }^{26}$. Tanto pelos objetivos declarados como pelas prioridades orçamentárias dos programas derivados do CPGS, China e Rússia temem que um ataque preemptivo seja a primeira ação por parte dos Estados Unidos em um

26 Segundo Lieber e Press (2006), a primazia nuclear se configura pela possibilidade de um estado desabilitar e anular a capacidade de segundo ataque (ou retaliação) nuclear de outro ator do sistema internacional. Portanto, segundo o marco teórico aqui utilizado (CEPIK, 2013), a primazia nuclear conforma a estrutura do sistema internacional, na medida em que dá o tom da hierarquia entre os atores, influenciando, nesse sentido, na sua própria polarização e no desenvolvido das relações interestatais. 
eventual conflito armado direto. Tal ataque eliminaria o seu poder de retaliação nuclear e, no caso da China, a própria estrutura de defesa convencional. O resultado de um risco dessa magnitude seria um aumento proporcional na percepção chinesa de ameaça, com a consequente necessidade de se modificar a doutrina de emprego nuclear. Se, por um lado, Li e Tong (2016, p. 159) argumentam que a China se mantem firme com a política de no-first use (NFU) de suas capacidades nucleares, por outro, eles reconhecem que isso pode vir a ser flexibilizado em um cenário em que os efeitos de um ataque convencional sejam equivalente ao de um ataque nuclear. Outros autores, como Khoo e Steff (2014), vão além e argumentam que o debate sobre a revisão do NFU já estaria ocorrendo no interior do Partido Comunista da China, onde uma posição mais incisiva quanto ao papel das forças nucleares estaria sendo defendida por um número crescente de oficiais.

Se as evidências de uma mudança definitiva na doutrina ainda são escassas, a análise das capacidades revela uma reação mais evidente. Em termos de aquisição de sistemas, as recentes opções estratégicas dos Estados Unidos, como o CPGS ou o Escudo Antimísseis, parecem estar gerando reações importantes na China. O país tem melhorado seus mísseis balísticos intercontinentais (ICBM), implementando a tecnologia MIRV 27, como no caso dos mísseis DF-41 e DF-5A (baseados em terra) e do JL-2 (baseado em submarino) (IISS, 2016, p. 12-15). Segundo Khoo e Steff (2014), o desenvolvimento de contramedidas adequadas para garantir a capacidade de retaliação nuclear da China frente ao Escudo Antimíssil se tornou um elemento significativo no esforço com relação às capacidades estratégicas.

A Rússia, por sua vez, também parece estar acelerando a atualização de seu arsenal nuclear, tendo substituído ou aprimorado praticamente metade de suas capacidades só na década passada. Moscou planeja melhorar todos os sistemas de guiagem, propulsão e armazenamento dos seus sistemas até 2020. Um dos sistemas mais significativos foi a atualização do ICBM móvel Topol-M (SS-27), que se diferencia qualitativamente de seus antecessores, pois adota a tecnologia MARV para guiagem terminal, o que aumenta significativamente a sua sobrevivência frente às defesas antimíssil balísticos atuais. Em 2011, foi produzida pela primeira vez uma versão embarcada em submarinos de um míssil balístico de longo alcance, o Bulava (SS-N-32), também com ogivas MARV, tendo entrado em serviço no ano seguinte (KHOO; STEFF, 2014). Além disso, uma versão avançada

27 Mísseis MIRV (Multiple Independently Targetable Reentry Vehicle) dividem-se em diversos veículos de reentrada independentes. Quando um ICBM MIRV é lançado, sua cabeça se fragmenta em diversas partes logo antes de adentrar a atmosfera, tornando sua interceptação muito difícil. 
do R-36M2 Voevoda (SS-18 Satan), o RS-28 Sarmat (SS-X-30 Satan 2), capaz de dividir sua ogiva em até 24 partes independentes com a tecnologia MIRV, vem tendo protótipos testados com sucesso desde 2011 e deve entrar em serviço até 2021 (IISS, 2016, p. 191).

\section{Conclusões}

Neste artigo, procuramos relacionar concepções de segurança mais amplas sobre o mundo contemporâneo (globalismo e Revolução nos Assuntos Militares) com escolhas e projetos de caráter tático e operacional (sob o conceito de ataque convencional global imediato), passando por suas implicações para o futuro do sistema internacional em termos de polarização e polaridade.

Primeiro, verificou-se que a concepção de globalismo, i.e crença na eliminação da distância estratégica entre as nações, deriva, em termos securitários, especialmente das interpretações teóricas centradas na Revolução em Assuntos Militares (RMA), onde a técnica é o centro da coerção e da tomada de decisão política. Decorrente dessa visão, encontra-se a crença na guerra ofensiva como mais forte e, segundo, o incentivo à preempção e à intervenção a fim de tomar a iniciativa e tentar garantir uma posição de primazia na hierarquia mundial de poder. Com base na pesquisa realizada, destacam-se quatro conclusões gerais.

A primeira é que a ideia inicial dos Estados Unidos de implementar o CPGS com base em mísseis balísticos convencionais revelou-se insustentável por razões técnicas (inviabilidade de se ter precisão pelo controle do míssil balístico na fase terminal) e políticas (Congresso americano avesso ao risco da ambiguidade nuclear).

A segunda conclusão é de que o debate atual nos Estados Unidos se centra na questão do perfil dos sistemas e não nos cenários de emprego. Nesse sentido, analisando as missões potenciais para o CPGS, sua existência atual só parece ser justificada pela questão da surpresa tática (necessária em ambientes altamente contestados, como no A2/AD), ao passo que as missões que exigem prontidão (contraterrorismo ou retaliação em geral) seriam melhor realizadas com as tecnologias atualmente disponíveis (drones, mísseis cruzadores subsônicos e mísseis balísticos).

Em terceiro lugar, conclui-se que os projetos mais aderentes ao conceito CPGS em desenvolvimento pelos Estados Unidos são um planador hipersônico de alcance quase global (Advanced Hypersonic Weapon, AHW) e, com alcance regional, um 
míssil cruzador com propulsão hipersônica (High Speed Strike Weapon, HSSW). Esse último projeto depende, primeiro, do sucesso da própria propulsão hipersônica (projeto X-51A Waverider). Qualquer uma das opções, no entanto, só será bem-sucedida se utilizada em ambientes informacionais sólidos, sustentados pela devida cobertura de satélites e meios aéreos de vigilância e reconhecimento. Na prática, são fortalecidas as missões de surpresa tática em detrimento da prontidão. Tais missões seriam, por exemplo, um ataque preemptivo contra força nuclear, um ataque preemptivo contra sistemas antissatélites (ASAT) ou mesmo a supressão de defesas antiaéreas.

Por fim, as implicações dessas escolhas ficam evidentes no terceiro nível da análise, o da política. Em suma, os sistemas baseados em CPGS contribuem diretamente para aumentar a instabilidade e a polarização por causa de suas ambiguidades (nuclear, de destino e de alvo), com a consequente aceleração do ritmo de escalada conflitiva em eventuais crises. Frente a isso, percebe-se que os sistemas de CPGS, ao invés de fortalecer a dissuasão convencional dos EUA e promover a estabilidade (na medida que evita utilizar ogivas nucleares), acaba gerando uma situação de incerteza generalizada, onde Rússia e China consideram a sua própria condição enquanto polos ameaçados. Em resposta, ambos têm acelerado o desenvolvimento de capacidades nucleares e convencionais, mas também considerado diminuir o limiar nuclear em sua doutrina de emprego. O CPGS, dessa forma, agrega-se a outros conceitos operacionais vistos como ameaçadores pelos outros polos do sistema, como o caso do Escudo Antimíssil, gerando, através da preempção, incentivos para que os atores busquem a iniciativa militar nas crises. A escalada à guerra nuclear, nesse contexto, talvez seja rápida demais para ser contida pela concertação política.

Portanto, o debate sobre os sistemas CPGS diz respeito tanto à estrutura (distribuição de poder), quanto à dinâmica política internacional. Por meio da análise realizada neste artigo, procuramos contribuir para uma teoria realista crítica que explique a vitória militar em condições de permanência da centralidade da política e do atrito. Mesmo que o desenvolvimento tecnológico militar venha a permitir a implementação de um conceito como o do CPGS por parte dos Estados Unidos, é importante que os demais países tenham claro os riscos e as implicações desse tipo de capacidade bélica. Como desdobramentos da pesquisa iniciada aqui, é necessário monitorar os tipos de missões, os cenários de emprego, os riscos de interpretação (missperception) em situações de crise e de tempo operacional acelerado. Sem esse tipo de análise, os debates sobre não proliferação e controle do uso de armamentos nucleares continuará incompleto e fragilizado institucionalmente. 


\section{Referências}

ACTON, J. M. Silver Bullet? Asking the Right Questions About Conventional Prompt Global Strike. Washington: Carnegie Endowment for International Peace, 2013.

ANDREASEN, S. Rethinking NATO's Tactical Nuclear Weapons. Survival, v. 49, n. 5, 2017. 47-53.

BIDDLE, S. Military Power: Explaining Victory and Defeat in Modern Battle. Princeton: Princeton University Press, 2004.

BOOT, M. The New American Way of War. Foreign Affairs, v. 82, n. 4, p. 41-58, 2003.

BROOKS, S.; WOHLFORTH, W. America Abroad: the United States' Global Role in the 21st Century. Oxford: Oxford University Press, 2016.

BURNS, R. D. The Missile Defense Systems of George W. Bush: a critical assessment. Santa Barbara: Praeger, 2010.

CEPIK, M. Segurança Internacional: Da Ordem Internacional aos Desafios para a América do Sul e para a CELAC. In: SORIA, A. B.; ECHANDI, I. A. Desafios estratégicos del regionalismo contemporáneo CELAC e Iberoamérica. San José: FLACSO, 2013. p. 307-324.

CEPIK, M.; MACHADO, F. O Comando do Espaço na Grande Estratégia Chinesa: Implicações para a Ordem Internacional Contemporânea. Carta Internacional, Vol. 6, No. 2, 2011, p. 112-130.

CIMBALA, S. Unblocking inertia: US-Russian nuclear arms control and missile defenses. Defense \& Security Analysis, v. 32, n. 2, 2016, p. 115-128.

CLAUSEWITZ, C. V. On War. New York: Oxford University Press, 2007.

CORDESMAN, A. Salvaging American Defense: The Challenge of Strategic Overstretch. Westport, Connecticut: Praeger Security International, 2007.

DEPARTMENT OF DEFENSE. Department of Defense Dictionary of Military and Associated Terms. Washington. 2014.

DINIZ, E. Armamentos Nucleares: Dissuasão e Guerra Nuclear Acidental. Carta Internacional, v. 11, n. 1, 2016, p. 9-62.

DUARTE, É. E. Military Power, Financial Crisis and International Security Panorama in the 21st Century. Austral: Brazilian Journal of Strategy \& International Relations, v. 2, n. 3, 2013. p. 9-43.

FIORI, J. L.; SERRANO, F.; MEDEIROS, C. O Mito do Colapso Americano. Rio de Janeiro: Record, 2008.

GAFFNEY, H. H. Capabilities-Based Planning in the Coming Global Security Environment. Monterey Strategy Seminar. Alexandria: Center for Strategic Studies. 2004. p. 12. GILPIN, R. War \& Change in World Politics. Cambridge: Cambridge University Press, 1981. GLOBAL SECURITY. Trident II D-5 Fleet Ballistic Missile. Global Security, 2011. Disponivel em: < http://goo.gl/q2JcK5 > . Acesso em: 12 Junho 2016. 
GORMLEY, D. M. US Advanced Conventional Systems and Conventional Prompt Global Strike Ambitions. Nonproliferation Review, v. 22, n. 2, 2015, p. 123-139.

HAMMES, T. X. Offshore Control: A proposed Strategy for an Unlikely Conflict. Strategic Forum, Insitute for National Security Studies, v. 278, p. 01-14, Junho 2012.

IISS. The Military Balance. International Institute for Strategic Studies. London: Routledge, 2016.

KARBER, P. Strategic Implications of China's Underground Great Wall. Georgetown University. Washington. 2011.

KHOO, N.; STEFF, R. "This program will not be a threat to them": Ballistic Missile Defense and US relations with Russia and China. Defense \& Security Analysis, Vol. 30, No. 1, 2014, p. 17-28.

KOPP, C. The Collapse of American Air Power: The Proliferation of Counter-Stealth Systems. Air Power Australia, 2009. Disponivel em: < http://goo.gl/cIB9Je > . Acesso em: 18 Junho 2016.

LI, B.; TONG, Z. Understanding Chinese Nuclear Thinking. Washington: Carnegie Endowment for International Peace, 2016.

LIEBER, K. A.; PRESS, D. G. The End of MAD? The Nuclear Dimension of U.S. Primacy. International Security, Spring 2006. 7-44.

LOBELL, S.; RIPSMAN, N.; TALIAFERRO, J. Neoclassical Realism, the State, and Foreign Policy. Cambridge: Cambridge University Press, 2009.

LONG, A.; GREEN, B. Stalking the Secure Second Strike: Intelligence, Counterforce, and Nuclear Strategy. Joural of Strategic Studies, v. 38, n. 1-2, 2015, p. 38-73.

MARTINS, J. M.; CEPIK, M. A. Defesa Nacional Antimíssil dos EUA: A lógica da Preempção e Suas Implicações Internacionais. In: ARTURI, C. Políticas de Defesa, Inteligência e Segurança. Porto Alegre: UFRGS/CEGOV, 2014. p. 14-47.

MEAD, W. R. The Tea Party and American Foreign Policy. Foreign Affairs, 2011. Disponivel em: < https://goo.gl/lRMBeP > . Acesso em: 07 jun. 2016.

MEARSHEIMER, J. J. A Tragédia Política das Grandes Potências. Lisboa: Gradiva, 2007. MORGAN, P. The State of Deterrence in International Politics Today. Contemporary Security Policy, v. 33 n. 1, 2012, p. 85-107.

NATIONAL RESEARCH COUNCIL. Naval Analytical Capabilities: improving capabilitiesbased planning. Washington: Naval Academies Press, 2005.

NATIONAL RESEARCH COUNCIL. U.S. Conventional Prompt Global Strike: Issues for 2008 and Beyond. Washington: National Academy Press, 2008.

NYE, J. Globalism Versus Globalization. The Globalist, 2002. Disponivel em: < https://goo.gl/ wk3ZUP > . Acesso em: 07 jun. 2017.

PAPE, R. Bombing to Win: Air Power and Coercion in War. New York: Cornell University Press, 1996. 
PARDESI, M. Is India a Great Power? Understanding Great Power Status in Contemporary International Relations. Asian Security, v. 11, n. 1, 2015, p. 1-30.

PORTER, P. The Global Village Myth: Distance, War and the Limits of Power. Washington: Georgetown University Press, 2015.

POSEN, B. Restraint: a New Foundation for U.S. Grand Strategy. Ithaca: Cornell University Press, 2015.

POSEN, B. R. The Command of the Commons: The Military Foundation of U.S. Hegemony. International Security, Summer 2003, p. 5-46.

SAALMAN, L. Prompt Global Strike: China and the Spear. APCSS/US Department of Defense. Washington. 2014.

SILOVE, N. Beyond the Buzzword: Three Meanings of Grand Strategy. Security Studies, 2017. 1-31.

SILVERSTONE, S. American Grand Strategy and the Future of Landpower in Historic Context. In: SILVA, J. D.; LIEBERT, H.; WILSON III, I. American Grand Strategy and the Future of U.S. Landpower. Carlisle: U.S. Army War College, 2014. p. 55-80.

SIMIONATO, G. H.; BAPTISTA, M.; FERRAZZA, V. The Missile Defense Systems. UFRGS Model United Nations, 2015. 279-310.

SUGDEN, B. M. Speed Kills: Analyzing the Deployment of Conventional Ballistic Missiles. International Security, v. 34, n. 1, 2009, p. 113-146.

TILL, G. Asia's Naval Expansion: An arms race in the making? New York: Routledge, 2012. TOL, J. V. Air-Sea Battle: a Point-of-Departure Operational Concept. Washington: CSBA, 2010.

VALLADÃO, A. O Século XXI será Americano. Vozes: Petrópolis, 1995.

VISENTINI, P. O mundo pós-Guerra Fria: O desafio do (ao) “Oriente”. Porto Alegre: Século XXI, 2005.

VOLPE, T. Atomic Leverage: Compellence with Nuclear Latency. Security Studies, v. 26, n. 3, 2017, p. 517-544.

WALTZ, K. Theory of International Politcs. Reading: Addison-Wesley Publishing Company, 1979.

WEEDEN, B.; CEFOLA, P. ; SANKARAN, J. Global Space Situational Awareness Sensors. Secure World Foundation. [S.1.]. 2010.

WOOLF, A. F. Conventional Prompt Global Strike and Long-Range Ballistic Missile: Background and Issues. Congressional Research Service. Washington. 2016.

ZHAO, T. Conventional Counterforce Strike: An Option for Damage Limitation in Conflicts with Nuclear-Armed Adversaries? Science \& Global Security, vol. 19, 2011, p. 195-222. 


\title{
As três tendências da guerra cibernética: novo domínio, arma combinada e arma estratégica
}

\author{
The three trends of cyberwarfare: \\ new domain, combined arms and strategic weapon
}

DOI: $10.21530 /$ ci.v12n3.2017.620

Augusto W. M. Teixeira Júnior ${ }^{1}$

Gills Vilar-Lopes ${ }^{2}$

Marco Túlio Delgobbo Freitas ${ }^{3}$

\section{Resumo}

O presente trabalho analisa como a guerra cibernética impacta a conduta da guerra hodierna. Partindo da teoria da guerra de Clausewitz e dos debates sobre revolução dos assuntos militares e poder aéreo, postulam-se três tendências com distintos níveis de modificação das formas de beligerância advindos do ciberespaço. A primeira delas se refere à criação de um novo domínio, o cibernético. A segunda vislumbra a incorporação do ciberespaço à guerra enquanto arma combinada, ou seja, incorporando-a aos instrumentos de força convencionais para a produção de efeitos cinéticos. A terceira tendência estipula o uso da guerra cibernética como uma arma estratégica, em moldes pareios aos da estratégia de dissuasão nuclear. Em termos metodológicos, a pesquisa se baseia, em primeiro plano, na revisão bibliográfica da literatura de segurança internacional e guerra cibernética e, secundariamente, na análise histórica dos seguintes acontecimentos recentes: Rússia-Estônia (2007), Rússia-Geórgia (2008), Stuxnet (2010) e Rússia-Ucrânia (2014). Objetiva-se assim construir um quadro de análise para melhor compreender como o fenômeno da guerra cibernética afeta a conduta da guerra do século XXI.

Palavras-chave: Guerra Cibernética. Ciberespaço. Conduta da Guerra. Segurança Internacional. Tendências.

1 Doutor em Ciência Política (UFPE). Professor do Programa de Pós-Graduação em Ciência Política e Relações Internacionais (PPGCPRI/UFPB) e do Departamento de Relações Internacionais (DRI/UFPB), em João Pessoa/ PB, Brasil. Coordenador do Grupo de Pesquisa em Estudos Estratégicos e Segurança Internacional (GEESI/ UFPB/CNPq). Contato: augustoteixeirajr@gmail.com.

2 Doutor em Ciência Política (UFPE). Grupo de Estudos de Defesa e Análises Internacionais (GEDAI) do Departamento de Ciências Sociais (DCS) da Universidade Federal de Rondônia (UNIR), em Porto Velho/RO, Brasil. E-mail: gills@gills.com.br.

3 Mestre em Relações Internacionais (UFF). Professor do Instituto Nacional de Pós-Graduação (INPG). Pesquisador do Instituto Pandiá Calógeras e GEESI (CNPq/UFPB). Contato: marcotuliodf@hotmail.com.

Artigo submetido em 07/02/2017 e aprovado em 08/05/2017. 


\begin{abstract}
This work analyzes how cyberwar impacts the conduct of modern warfare. Departing from Clausewitz Theory of War and the debates on Revolution in Military Affairs and Air Power, three trends are posited in which different levels of modification of the forms of belligerence coming from the cyberspace are attested. The first one refers to the creation of a new domain, the cyber domain. The second trend envisions the development of the cybernetic means combined with conventional weapons able to produce kinetic effects. The last trend stipulates the use of cyberwar as a strategic weapon, like the nuclear deterrence strategy. These trends are based on historical accounts of international security and cyberwar literature, as: Estonia (2007), Russia versus Georgia (2008), Stuxnet (2010) and Russia versus Ukraine (2014). The objective here is to build a framework for a better understanding of how the phenomenon of cyberwar affects the conduct of war in the $21^{\text {st-century. }}$
\end{abstract}

Keywords: Cyberwar. Cyberspace. Conduct of War. International Security. Trends.

\title{
Introdução
}

O panorama do pós Guerra Fria trouxe desafios explanatórios e disciplinares às relações internacionais, especialmente aos estudos estratégicos e de segurança internacional. Atualmente, observa-se o crescente interesse por pesquisas em relações internacionais sobre o ciberespaço, especialmente em seu aspecto securitário (PORTELA, 2016, p. 108). Na perspectiva do debate sobre transformações na conduta da guerra, as ideias de "redução da fricção" e “distanciamento do front” (PERON, 2016) são a ponta de lança da chamada revolução dos assuntos militares (RAM), ou revolution in military affairs (RMA), da qual a guerra cibernética é caudatária. No plano contextual, alguns países e organizações passaram a considerar o ciberespaço como um domínio combatente, produzindo, assim, mudanças institucionais, estratégicas e doutrinárias. Como exemplos dessa inclinação de pensamento estratégico-militar, citamos o U.S. Cyber Command (USCYBERCOM), o Cooperative Cyber Defence Centre of Excellence (CCD COE) da Organização do Tratado do Atlântico Norte (OTAN) e a nova arma — ou ramo (branch) - chinesa para combater no ciberespaço ${ }^{4}$.

Pode-se definir guerra cibernética como um estado de coisas em que o poder militar utiliza meios, estratégias e ferramentas no ciberespaço para alcançar seus objetivos. Tal definição ampara-se na concepção mais ampla de poder cibernético,

4 Cf. Estados Unidos da América (2016), Minárik (2016) e SPUTINIK (2016), respectivamente. 
ou cyber power (SHELDON, 2013), que diz respeito ao uso estratégico do ciberespaço. Nessa perspectiva, a guerra cibernética é uma modalidade beligerante de uso e atuação predominantes do ambiente cibernético para obter informações privilegiadas e/ou desestabilizar sistemas computadorizados de um país ${ }^{5}$.

Este trabalho pretende demonstrar como, no limiar do século XXI, atores estatais - e terceiros a seu mando - utilizam tais meios de força em ações político-estratégicas. Nesse sentido, o problema de pesquisa indaga: como a tecnologia cibernética pode transformar a conduta da guerra?

Acreditamos que essa reflexão impõe três grandes problemas aos estudos estratégicos e de segurança internacional, no sentido de que o ciberespaço:

1. revolucionaria a conduta da guerra, mitigando a relevância dos domínios clássicos da terra, mar, ar e espaço sideral;

2. permitiria alcançar a vitória militar sem dispêndio de muita energia cinética; e

3. faria emergir uma mudança paradigmática na própria conduta da guerra, semelhante ao emprego dissuasório das armas nucleares.

Ao explanar cada uma dessas questões, analisamos três tendências que englobam os impactos da tecnologia cibernética no pensar e agir militares. A primeira delas diz respeito à assunção doutrinária de que o ciberespaço é um novo domínio (MINÁRIK, 2016), do qual se pode traçar um paralelo com a incorporação do “ar” como nova dimensão da guerra. A segunda tendência vislumbra o desdobramento dos meios cibernéticos, combinados aos instrumentos convencionais de força voltados à conduta da guerra (LANGNER, 2011). E a derradeira tendência estipula a guerra cibernética como uma arma estratégica (KREPINEVICH, 2012), em moldes pareios ao nuclear, para retirar do combate o fulcro da dinâmica bélica.

O percurso teórico deste artigo dialoga com a história da guerra cibernética à luz dos debates sobre transformação militar6. Dado que esse tema é recente nas relações internacionais, não é possível afirmar a existência de teorias robustas acerca do fenômeno da guerra cibernética (SHELDON, 2013). Logo, as

5 Nessa definição de guerra cibernética como domínio, seus efeitos e empregos são ligeiramente diferentes, quando considerada enquanto arma combinada ou estratégica.

6 “O termo 'transformação militar' pode simplesmente ser entendido como uma 'profunda mudança' nos assuntos militares. Não seria necessária uma mudança rápida ou de amplo escopo, nem o descarte daquilo que ainda funciona bem. As mudanças, no entanto, deveriam ser dramáticas ao invés de aprimoramentos marginais como melhores aeronaves, carros de combate ou navios. Transformação é um processo sem um ponto final” (DAVIS, 2010, p. 11, tradução nossa). 
ferramentas conceituais e analíticas disponíveis encontram-se mais na história e na revisão da literatura do que em um edifício teórico bem consolidado. Por tal razão, focamos a literatura especializada em guerra cibernética, mantendo um diálogo com a teoria política da guerra clausewitziana. Essa opção conduzirá o trabalho a uma preferência por autores representativos do esforço de conexão do fenômeno da guerra cibernética com construtos conceituais e doutrinários dos estudos estratégicos e de segurança internacional? ${ }^{7}$.

No que tange à metodologia, este trabalho pauta-se no estilo qualitativo de pesquisa, em que pesem os métodos da pesquisa bibliográfica - cuja análise busca identificar tendências de um fenômeno a partir da categorização da literatura especializada (VAN EVERA, 1997) - em estudos estratégicos e da análise histórica de acontecimentos emblemáticos ao tema, envolvendo a Rússia - Estônia em 2007, Geórgia em 2008 e Ucrânia em 2014 - e o worm ${ }^{8}$ Stuxnet em 2010, reconhecido como a primeira arma cibernética. O objetivo aqui não é aplicar a metodologia de estudo de caso (GEORGE; BENNET, 2005) ou de política comparada de small-N (LANDMAN, 2008) e, sim, extrair as principais tendências sobre o impacto da guerra cibernética na conduta da guerra e, portanto, na segurança internacional.

Em perspectiva histórica, a primeira seção apresenta a guerra cibernética no contexto do debate sobre RAM. Com base na literatura, a segunda seção explica a função metodológica da analogia entre os espaços cibernético e aéreo enquanto domínios militares. Como resultado dessa base no pensamento estratégico, a terceira seção analisa as três tendências da incorporação do ciberespaço na conduta da guerra, quais sejam: novo domínio, arma combinada e arma estratégica.

\section{Revolução nos assuntos militares e poder aéreo: modelos para a incorporação do ciberespaço à conduta da guerra}

Analisamos agora o fenômeno do qual o tema em tela é uma expressão: a guerra. Apesar de quase 200 anos da publicação da magnum opus de Clausewitz (2010), sua teoria política da guerra ainda se mostra assaz útil para o pensar estratégico. Segundo ele, a guerra é um ato de força voltado a submeter o inimigo à

7 Por isso, não damos muita atenção ao pensamento estatal sobre o tema. Contudo, dada a relevância da matéria, futuros artigos abordarão tal aspecto.

8 Worms são programas de computador que facilitam a intrusão em sistemas de hardware e roubam informação desses (LOBATO; KENKEL, 2015, p. 27). 
nossa vontade. Para Clausewitz (2010), a guerra é, ao mesmo tempo, um fenômeno político e uma atividade social. Não obstante o combate ser o principal meio da guerra, essa era composta pela interação de distintas instâncias políticas, militares e sociais combinadas a diferentes motivações no tocante ao evento bélico. Essa "trindade" clausewitziana é formada, portanto, por governo, militares e povo, os quais se movem, respectivamente, pela razão, probabilidade e paixão.

Instituições, interesses e paixões contribuíam para estruturar as dimensões materiais e psicológicas da guerra. Seu significado é mediado por idiossincrasias sociais e temporais. Para Clausewitz (2010), tal fenômeno é marcado pelo uso instrumental da violência, direcionada e justificada politicamente. Se o combate é o principal meio da guerra, como reduzir o desgaste humano e material ao longo dos engajamentos? Como apreender em profundidade a realidade do campo de batalha, no sentido de ver além da colina? Fricção ${ }^{9}$ e névoa da guerra ${ }^{10}$ são tanto limitadoras do pleno uso da força - guerra absoluta - quanto partes indeléveis dos desafios enfrentados por comandantes militares, desde tempos imemoriais, em sua busca pela vitória. Apesar de considerar importante a evolução tecnológica, Clausewitz (2010) era cético quanto à capacidade de esse vetor afetar a natureza da guerra. Por outro lado, entendia que avanços tecnológicos poderiam, sim, ser fundamentais para alterar a conduta da guerra. É nesse sentido que a conexão entre tecnologia e mudanças dos assuntos militares apresenta-se útil para pensar transformações referentes ao uso político da força, que, neste caso, referem-se ao advento da era da informação e da guerra cibernética. Considera-se que a RAM seja um importante ponto de partida para entender como mudanças tecnológicas - evolutivas ou revolucionárias — , sociais e políticas afetam as formas de se fazer a guerra.

Antes mesmo da popularização do tema RAM nos Estados Unidos da América (EUA), Brzezinski (1989) já destacava o papel da dianteira tecnológica estadunidense como fundamental para a vitória na confrontação bipolar. A leitura de Brzezinski (1989) sobre o colapso da União das Repúblicas Socialistas Soviéticas (URSS) dialoga com uma transformação profunda nas relações internacionais, a saber: a revolução da informação.

9 Em analogia à física, Clausewitz (2010) afirma que a fricção na guerra é a força que torna coisas fáceis, difíceis. Fatores físicos - como clima e relevo - e psicológicos - a exemplo de moral e medo - competiam para diferenciar a "guerra real" da "guerra no papel".

10 Definida por Clausewitz (2010), “névoa da guerra” - nebel des kriegs - caracteriza-se pelas incertezas das reais intenções inimigas, ou seja, é a falta de conhecimento dos planos adversários que podem gerar grande desperdício de recursos. 
Com a substituição de sistemas analógicos por digitais, a incorporação da computação nos sistemas de comando e controle $\left(\mathrm{C}^{2}\right)$ e a eficiência produtiva do capitalismo ocidental, a nova revolução tecnológica empurrava o mundo à era da informação, com profundos impactos também na arte da guerra. Por exemplo, a internet, surgida no contexto da Guerra Fria, passa ao domínio público ainda nos anos de 1980 e se populariza nos de 1990, quando a luta contra as ameaças cibernéticas toma dimensões políticas (LOBATO; KENKEL, 2015, p. 38). Emergia lentamente um novo paradigma de combate, característico dessa nova era, a information warfare (BELLAMY, 2001).

No marco dos debates sobre transformação militar (SLOAN, 2012), a information warfare é um paradigma de beligerância em que os antagonistas "combatem" em um ambiente de informação, no qual as dinâmicas ofensivas e defensivas se caracterizam sobretudo pela busca de aquisição e degradação de informações e pelo uso de sistemas inimigos e negação de acesso. É nesse contexto que se tornam possíveis a inserção do ciberespaço nas doutrinas militares e o surgimento de novas formas de combate, a exemplo do previsto pela ideia de "guerra de terceira onda” (PERON, 2016), na qual a supremacia da informação seria primordial para a vitória.

Diante desse quadro, podemos contextualizar o surgimento da tecnologia cibernética no âmbito da RAM. Porém, cabe diferençar "evolução" e "revolução" em assuntos militares. De acordo com Andrews (1998), a diferença reside na maturação da tecnologia na condução da guerra. A evolução militar ocorre, segundo o autor, quando se aplicam novas tecnologias na guerra, que levam gerações para atingir o seu ápice. Em contraste com essa leitura gradualista, surgiu na União Soviética o entendimento de que a introdução de tecnologias poderia provocar mudanças drásticas na forma de guerrear (PROENÇA JR; DINIZ; RAZA, 1999). Historicamente, a gênese da ideia da RAM ${ }^{11}$ é atribuída ao marechal soviético Nikolay V. Ogarkov, o qual sugere, em 1980, que a revolução ${ }^{12}$ tecnomilitar em curso nos anos de 1970-80 se explicava pelo desenvolvimento de munições guiadas com precisão, pelos avanços tecnológicos na área de vigilância e pelos sistemas de distribuição de informações (PROENÇA JR; DINIZ; RAZA, 1999). Portanto, uma RAM ocorre

11 Apesar de semelhantes, a expressão Military-Technical Revolution (MTR) - de origem soviética - seria substituída nos Estados Unidos pelo conceito de RAM, cunhado por Andrew W. Marshall, diretor do gabinete de aviação do U.S. Department of Defense (ANDREWS, 1998).

12 No âmbito da "ciência militar" soviética, a análise do processo da evolução dos assuntos militares ganhou a alcunha de "revolução" devido a uma questão ideológica. Por uma analogia à própria Revolução Russa, eles valorizavam a palavra "revolução" como uma forma essencial de progresso da história. 
quando a nova tecnologia é inserida no âmbito doutrinário e organizacional, provacando mudanças revolucionárias (ANDREWS, 1998).

A RAM mostra-se, portanto, politicamente atraente no período pós Guerra Fria, pois promete maiores poder de fogo e eficácia militar com menos custos, maior capacidade expedicionária e mais rapidez na condução de operações militares regionais (LILES et al., 2012). O predomínio de guerras caracterizadas pela assimetria das capacidades entre beligerantes e a heterodoxia estratégicotática introduzem múltiplos desafios para o conflito e as forças armadas que, ao largo dos debates acadêmicos, já incorporam o domínio cibernético à conduta da guerra $^{13}$. No contexto em que o ambiente virtual guarda e protege informações sensíveis e desempenha papel fundamental à gerência de áreas importantes da defesa nacional, o ciberespaço se torna também um novo front, meio ou domínio, a partir do qual é possível produzir efeitos estratégicos (SHELDON, 2013).

Independentemente das possibilidades de evolução ou revolução das dinâmicas de transformação militar, persiste a necessidade de influenciar o inimigo, por meio da possibilidade ou do direto uso da força como lógica inerente à guerra (CLAUSEWITZ, 2010). Ao analisar a história militar, percebemos que, apesar das inovações e transformações castrenses, seus protagonistas basicamente perseguiam o mesmo objetivo, a saber: a vitória na guerra, seja ela de tipo ilimitada ou limitada (BIDDLE, 2010; CLAUSEWITZ, 2010). É preciso, pois, compreender como a tecnologia contribui para a contemplação desse objetivo. Consoante Proença Jr (2011, p. 182), "vir a ter vantagens combatentes a partir de promessas tecnológicas é o que anima uma grande parte do projeto de força, e isso depende da exploração do desempenho técnico de artefatos, sistemas e pessoal”, ou seja, para a esfera militar, é necessário saber como uma tecnologia será utilizada, e, para isso, deve-se prioritariamente compreender suas promessas e limites. Com o ciberespaço não é diferente. O processo de incorporação de uma nova tecnologia no campo de batalha é normalmente incentivado e saudado por entusiastas que, na tentativa de compreender seu potencial emprego, acabam "hiperdimensionando" suas potencialidades, como possivelmente ocorre com o ciberespaço.

Apesar de a literatura revisada observar impactos estratégicos do ciberespaço nos conflitos armados contemporâneos, alguns autores, como forma de melhor avaliar os desdobramentos dessa nova dimensão da guerra, voltam-se para o

13 Como é o caso do acordo cibernético celebrado entre China e EUA em 2015 (KASPERSEN, 2015). 
surgimento de novos vetores de força nos domínios tradicionais ${ }^{14}$. Entre esses, destaca-se o domínio aéreo, cuja comparação histórica mostra-se metodologicamente útil para o estudo do ciberespaço na ótica dos estudos estratégicos.

Apesar de a discussão sobre guerra cibernética ser relativamente recente na academia, pode-se compará-la ao desafio que o surgimento do poder aéreo legou às relações internacionais e aos estudos estratégicos em seu tempo. Se, nos anos de 1950 e de 1960, o desenvolvimento de vetores de entrega de armamento nuclear relativizava a compreensão então acordada sobre os limites geográficos para a projeção do poderio militar, é com a aviação que surge o grande debate sobre revolução militar na primeira metade do século $\mathrm{XX}^{15}$. Tanto as guerras no ar quanto no ciberespaço questionam o peso condicionante da geografia sobre a estratégia e a condução de operações militares. Embora criticada, a ideia da "real possibilidade de uma guerra restrita aos domínios adjacentes, como o cibernético" (BOHN; NOTHEN, 2016, p. 90) vem motivando maiores investigações sobre a relação ciberespaço-guerra.

O poder aéreo surge, então, com a promessa revolucionária de perceber, conduzir e vencer guerras. As ideias de que o ar constituiria um domínio novo e que o bombardeio seria a arma definidora da guerra do futuro demonstravam uma clara tendência à hiperestimação (MACISAAC, 2003). Após a Primeira Grande Guerra, o avião, inicialmente uma inovação tecnológica, gera condições para a incorporação de um novo domínio, o ar. Semelhantemente ao debate hodierno acerca da guerra cibernética, as discussões entre a comunidade de estrategistas e planejadores militares sobre essa nova realidade não é conclusiva. Nesse ponto, a evolução patente ao poder aéreo, de uma arma subordinada às demais em direção à constituição de domínio e arma independente - estratégica —, mostrase útil para ponderar como o ciberespaço afeta a conduta da guerra atualmente. Embora a instrumentalidade da comparação entre, de um lado, domínios aéreo e cibernético e, do outro, o surgimento da guerra no ar e no ciberespaço, seja útil para analisar tendências, apresentamos os limites dessa comparação, em virtude de características peculiares do ciberespaço em relação aos demais domínios.

14 Liles et al. (2012) são representativos dos que adotam a aplicação de princípios tradicionais da guerra terrestre para entender a cibernética. Bohn e Nothen (2016) preferem a analogia do ciberespaço como um "espaço comum”, advinda das teorias do poder marítimo. Já Birdwell e Mills (2011) discutem a guerra cibernética tendo em tela o acumulado teórico sobre o poder aéreo.

15 Ao postular as caraterísticas revolucionárias da aviação militar como arma estratégica, Giulio Douhet é um dos teóricos do século XX que melhor representam a articulação entre tecnologia e quebra de paradigmas na conduta da guerra (MACISAAC, 2003). 
Ao contrário dos domínios tradicionais, o cibernético é uma criação humana, presente em vários meios: do pen drive à "nuvem" (LIBICKI, 2012). Distintamente do que postulam Liles et al. (2012), ao pleitear subordinar as operações cibernéticas de acordo com os princípios da guerra terrestre ${ }^{16}$, a capacidade de moldar o ciberespaço torna-se mais importante que o poder de fogo ou de manobra (LIBICKI, 2012). Enquanto os domínios tradicionais impõem diversos custos de operação para atores não estatais, o ciberespaço se caracteriza por: baixo custo de entrada em operação, atuação multistakeholder e fluidez extremada (SHELDON, 2013). É, portanto, o domínio em que se cria, armazena, transmite e manipula a informação e em que o poder cibernético converte a informação em efeito estratégico (SHELDON, 2011, p. 306).

De acordo com Libicki (apud Sheldon, 2013), o ciberespaço compõe-se de três camadas:

1. física: hardware, cabos, satélites, roteadores e outros componentes infraestruturais;

2. sintática: código/software que formata, instrui e controla informação; e

3. semântica: interface ciberespaço-humana em que a informação é dotada de significado/sentido para seres humanos.

O controle, contudo, de uma das camadas do ciberespaço não confere domínio sobre as outras (LIBICKI apud SHELDON, 2013, p. 304). Entretanto, o emprego militar dos vetores cibernéticos contribui para incrementos de força ou acessórios ao seu emprego no campo de batalha, tais como: melhoria da qualidade de coleta de dados dos serviços de inteligência, precisão e rapidez de ataques teleguiados, proteção de estruturas estratégicas de informação ${ }^{17}$ e avanço na capacidade de C² (BIRDWELL; MILLS, 2011). Essas são tarefas a que o uso da tecnologia cibernética pode contribuir, acarretando possível diminuição da névoa da guerra (COHEN, 2010). Como contraste, o excesso de informação, que dificulta o gerenciamento de dados entre centros de $\mathrm{C}^{2}$ e forças combatentes, pode, na verdade, aumentar a névoa da guerra. Esse efeito, que reforça o ceticismo clausewitziano quanto à névoa da guerra, é chamado de digital divide (BIDDLE, 2010).

16 São estes os nove princípios: objetivo, ofensiva, massa, economia de força, manobra, unidade do comando, segurança, surpresa e simplicidade.

17 Estruturas estratégicas - ou infraestruturas críticas - de informação são componentes necessários a: transmissão de informações, redes de banda larga e satélites; sistemas de comunicação; e computadores, televisores, telefones, rádios e outros produtos que viabilizam o acesso a esses serviços. 
Outro possível input que a guerra cibernética traria à conduta bélica diz respeito à preferência estratégica. O conjunto das características expostas acima apresenta oportunidades expressivas para a ocorrência de operações ofensivas e, em contrapartida, dificulta ações defensivas. Para Libicki (2012, p. 323), as operações cibernéticas desse tipo, que exploram as vulnerabilidades dos sistemas-alvo, evidenciam a capacidade ofensiva que o ciberespaço enseja nos assuntos militares, mundo afora. Distintamente da preferência pela defesa encontrada na leitura clausewitziana, autores como Birdwell e Mills (2011), Liles et al. (2012) e Sheldon (2013) concordam ao enfatizar que a ofensiva é a forma dominante de guerrear no ciberespaço. Ataques mecânicos, eletromagnéticos ou digitais podem originar-se do ciberespaço, oscilando desde a produção de efeitos cinéticos até virtuais.

Apesar dessa euforia, Liles et al. (2012) abordam a questão de a literatura não possibilitar afirmar se a guerra cibernética é o uso do ciberespaço como domínio para o combate (BIRDWELL; MILLS, 2011) ou é o próprio combate no domínio do ciberespaço (LIBICKI, 2012). Como se observa, o fenômeno associado ao surgimento do poder aéreo e sua promessa revolucionária, a hiperestimação retorna contemporaneamente com foco no ciberespaço. Atualmente, grande parte da literatura sobre o uso estratégico-militar do ciberespaço coloca essa nova dimensão do conflito não só como revolucionária, mas igualmente como apocalíptica ${ }^{18}$. Outro aspecto relevante consiste nas perspectivas mais otimistas quanto à incorporação do ciberespaço na conduta das operações militares - tais perspectivas apresentam a guerra como um fenômeno não trinitário. Consoante tal visão, a guerra no ambiente cibernético poderia ser travada sem a interferência de um dos entes da trindade clausewitziana (SLOAN, 2012).

Para melhor analisar os desdobramentos desses debates, expõem-se a seguir as três principais tendências da condução da guerra cibernética.

\section{Três tendências para se pensar a conduta da guerra no ciberespaço}

Analisamos as seguintes tendências contemporâneas da guerra cibernética: (1) expressão do predomínio do novo domínio cibernético, operando como arma independente; (2) apenas nova ferramenta para alcançar a vitória em "velhos domínios”, na forma de arma combinada; e (3) arma estratégica.

18 Sobre o cenário extremado de cyber Pearl Harbor, ver Bumiller e Shanker (2012) e Clarke e Knake (2015). 


\section{Primeira tendência: guerra cibernética como novo domínio militar}

Desde a primeira Guerra do Golfo, impera no debate estratégico-militar a percepção de que a RAM seria dominada pela supremacia dos vetores aéreos de força e pela integração de sistemas de $\mathrm{C}^{2}$ nos âmbitos cibernético e material. A Guerra do Iraque, de 1991 a 1992, deixa claro, no que tange à literatura consultada, que importantes transformações na conduta da guerra estavam em curso àquela época (SLOAN, 2012).

Associado ao advento da guerra centrada em redes (GCR), dava-se cabo à revolução do "sistema dos sistemas" (COHEN, 2010). A fim de compreender essas transformações tecnobélicas, Bellamy (2001) formula uma tipologia das formas de $\mathrm{GCR}^{19}$, a qual pode ser aproveitada também para se pensar prospectivamente modelos de emprego do ciberespaço na guerra contemporânea. Para Liles et al. (2012, p. 172), a GCR aumenta o escopo e a visão do estrategista, haja vista que lhe proporciona a capacidade de utilizar a computação ubíqua para tomar decisões e comunicar-se no campo de batalha. É nesse contexto que se alça o ciberespaço à condição de novo domínio estratégico (BOHN; NOTHEN, 2016; KASPERSEN, 2015). Na era da informação, as infraestruturas de rede fazem parte do repertório de questões estratégicas (BOHN; NOTHEN, 2016), constituindo, possivelmente, um novo front.

Novas ferramentas e processos impactam a arte da guerra. Instrumentos, como as chamadas armas cibernéticas, proporcionam aquisição de informação necessária para o campo de batalha. Contudo, suas consequências precisam ser entendidas também na esfera estratégica. Desse modo, Liles et al. (2012, p. 172) salientam que se deve entender a guerra cibernética como um conjunto de operações centradas em informação em que ações ofensivas e defensivas contra centros de $\mathrm{C}^{2}$ predominam. Assim, a informação é um produto importante no front. Com informação precisa, um comandante desdobra suas forças, projeta seus contingentes contra os pontos vulneráveis do inimigo, alcança a vitória. Para o tomador de decisão civil, a informação é igualmente vital, pois, com ela, formula melhor os objetivos para alcançar os fins políticos, via o emprego da força. A informação, portanto, tem o potencial de mudar o comportamento dos atores, violentamente ou não. Eis aí a essência dos que defendem a guerra cibernética como novo domínio de operações militares.

19 São elas: $C^{2}$ warfare, software warfare e informational warfare (BELLAMY, 2001). 
De forma a testar preliminarmente o uso do domínio cibernético em conflitos contemporâneos, discutem-se três eventos representativos, quais sejam: os impactos dos vultosos ataques cibernéticos sofridos pela Estônia em 2007; a ofensiva militar, precedida por ataques cibernéticos, da Rússia na Geórgia em 2008; e a empreitada bélica russa no ciberespaço ucraniano em 2014.

É ponto relativamente pacífico, na literatura de segurança internacional, que a crise na Estônia em 2007 constitui um marco nos estudos sobre guerra cibernética (CLARKE; KNAKE, 2015; LIBICKI, 2012; NYE JR, 2008). Estopim do conflito cibernético, o governo estoniano removeu uma estátua em homenagem aos soviéticos mortos na Segunda Guerra Mundial, do centro da capital, Tallinn, para um cemitério afastado, culminando com protestos russófonos no país e na Rússia. Ataques virtuais afetaram negativamente o funcionamento das infraestruturas de TIC da Estônia, comprometendo seus serviços derivados. Como frisam Clarke e Knake (2015) e Oppermann (2010), a Estônia detinha uma das mais modernas infraestruturas de TIC do mundo, mas os ataques cibernéticos foram tão impactantes que a OTAN investigou o caso e criou o CCD COE, em Tallinn. Nesse ínterim, o governo estoniano acusou veementemente Moscou pelos atentados à sua "soberania cibernética". Apesar de nunca ter sido provada a atribuição dos ataques, a capacidade de poder cibernético (LIBICKI, 2012) contra a Estônia dificilmente poderia ter sido conduzida sem o auxílio de um grande player estatal. Embora Clarke e Knake (2015) apontem para essa direção, Moscou continua negando participação (CROFT; APPS, 2014).

Destacamos duas ponderações sobre esse caso. Primeiro, devido ao tipo de ataque cibernético usado - $\operatorname{DDoS}^{20}-$, não se pode concluir acerca da participação do governo russo. Segundo, embora não tenham ocorrido ataques convencionais, com efeitos cinéticos, antes ou depois dos vultosos ataques cibernéticos, esse caso, ainda assim, é emblemático, para os estudos internacionalistas e estratégicos, ao demonstrar como um Estado altamente conectado ao ciberespaço, especialmente à internet, pode ter suas estruturas estratégicas de TIC seriamente danificadas em um cenário de guerra cibernética.

A configuração do ciberespaço como um novo front, atrelado a um domínio independente na guerra, tem no caso da Estônia o seu teste inicial. Apesar disso,

20 Conhecido por distributed denial-of-service (DDoS), ou negação de serviço, "que ocorre a partir da sobrecarga do sistema[,] e não de uma invasão. Geralmente, um computador[-]mestre comanda milhares de computadores denominados zumbis, que passam a funcionar como máquinas escravizadas” (GAMA NETO; VILAR LOPES, 2014, p. 76). 
um ano depois, outro case demonstra a progressiva, porém não totalmente comprovada, articulação do ciberespaço com efeitos cinéticos. Em 2008, a república da Geórgia envolve-se em uma onda de ataques virtuais. Diferentemente da Estônia, tais ataques foram o prelúdio de uma guerra convencional. Pela primeira vez, uma ofensiva em domínios tradicionais foi precedida por ataques na dimensão cibernética. Um mês antes dessa ofensiva militar russa, em julho de 2008 (OPPERMANN, 2010), a infraestrutura de TIC georgiana foi severamente danificada. Com o sistema sob ataque, não só serviços online nacionais, mas também fornecedores internacionais, receosos, desligam-se do Estado georgiano. Com seus sistemas de informação e comunicação enfraquecidos, ficou ainda mais difícil para a Geórgia mobilizar-se e, consequentemente, defender-se dos ataques convencionais. Sobre tais eventos, Nye Jr (2008) afirma ser esse o evento que abre caminhos sem precedentes para se compreender a guerra cibernética como uma das facetas da conduta da guerra no século XXI.

Outro evento seria ainda mais elucidativo sobre a tendência do ciberespaço como domínio de operações. Imerso na conjuntura da aguda crise política sobre a anexação da Crimeia, e da posterior guerra civil ucraniana, Moscou toma medidas para controlar a segurança daquele importante espaço geoestratégico de projeção de poder russo, especialmente no Mar Negro. Em março do mesmo ano, a maioria da população da Crimeia vota pela secessão da Ucrânia e unificação à Rússia. O Secretário-Geral da OTAN, à época, classifica isso como uma possível violação ao direito internacional, ocasionando também a ira de hackers "ucranianos", a ponto de alguns sites da OTAN serem também tirados do ar, por meio do já utilizado tanto na Estônia quanto na Geórgia - ataque DDoS (CROFT; APPS, 2014).

No âmbito dos estudos estratégicos, a questão se mostra ainda mais complexa quando especialistas em segurança da informação afirmam que as redes de computadores do governo ucraniano foram ocultamente monitoradas pelo Kremlin, anos antes de a crise da Crimeia estourar (JONES, 2014). A descoberta de que um software malicioso (malware) estaria silenciosamente sabotando sistemas informacionais da Ucrânia foi feita pelo BAE Systems, braço tecnológico das forças armadas britânicas, que cunhou o nome "Snake" para designar esse que é, na verdade, um kit de ferramentas de espionagem cibernética (BAE SYSTEMS, 2014, p. 6). Tais análises mostram que o Snake infectou máquinas de nove países ${ }^{21}$ (BAE SYSTEMS, 2014, p. 6). Com base nos dados fornecidos pela empresa,

21 Bélgica, EUA, Geórgia, Grã-Bretanha, Hungria, Itália, Lituânia, Romênia e Ucrânia. 
percebe-se que: (i) a Ucrânia é o primeiro e o mais infectado dos países; (ii) a Rússia, principal alvo de malwares no mundo, sequer teve uma única infecção; e é justamente em 2014, na Ucrânia, que o Snake mais se manifesta, ou seja, envia informações capturadas para um receptor remoto. As conclusões sobre o Snake seguem a mesma lógica das de outras "armas cibernéticas", i.e., a existência de arquitetura e engenharia de software bastante robustas e sofisticadas (BAE SYSTEMS, 2014, p. 26), a ponto de ser altamente improvável ser projetado por pessoas sem alto grau de conhecimento e treinamento fora do ordinário (JONES, 2014), habilidades essas vistas nas principais potências cibernéticas. Entretanto, apesar de ser uma arma cibernética, o Snake se distingue do worm Stuxnet, por exemplo, por não produzir efeitos cinéticos 22 .

Como acontece em 2007, mais uma vez, especialistas em computação apontam a Rússia como principal interessada em saber o que determinados ucranianos faziam e como funcionavam suas redes de C² (JONES, 2014). Registre-se também que o acesso à rede de telefonia móvel e internet na Crimeia sofreu fortes ataques durante toda a crise, de acordo com o próprio governo ucraniano (LEE, 2014). Como ocorrido na Estônia e na Geórgia, a maioria dos analistas militares não duvida que a crise ucraniana marca um ponto-chave na história da guerra cibernética (JONES, 2014).

Como síntese da primeira tendência, pode-se dizer que acontecimentos recentes permitem afirmar que crises e guerras entre Estados e atores não estatais têm envolvido o ciberespaço como novo domínio militar e teatro de operações. Contudo, até o momento, apesar da pertinência das ideias de "eliminação da fricção” prometidas pelo ideário da RAM, a materialidade da guerra cibernética não demonstra ainda expressiva capacidade de comprometer os meios de luta do inimigo, muito menos de produzir vetor estratégico de força capaz de proporcionar vantagens expressivas no campo de batalha. A impossibilidade de identificar, na maioria dos casos, os responsáveis pelos ataques cibernéticos mina a capacidade de se averiguar, com precisão, as relações de causalidade entre domínio cibernético e uso da força cinética. Porém, o fato é que Estados estão tirando proveito do ciberespaço para atuar contra seus inimigos, em particular mediante o uso estratégico da informação - acesso ou negação - , o que leva à nossa segunda tendência.

22 Para Sheldon (2013, p. 312), o Stuxnet comprova que uma capacidade cibernética ofensiva pode mirar, de forma mais ou menos precisa, um sistema remoto, comprometê-lo e causar-lhe destruição física. 


\section{Segunda tendência: guerra cibernética como arma combinada}

Os acontecimentos analisados para formular a primeira tendência não permitem afirmar, categoricamente, que o ciberespaço, como domínio independente, é capaz de vencer, per se, batalhas ou produzir vantagens táticas ou estratégicas significativas a quem o usa. Apesar de os relatos de emprego do ciberespaço como domínio em conflitos contemporâneos recaírem majoritariamente na presumida experiência russa, a vantagem central dessa tendência reside em sua conexão com a GCR e com o processo de transformação militar liderada pelos EUA (SLOAN, 2012).

Com isso em mente, buscamos evidenciar aqui a conexão entre ciberespaço e uso da força, em que se destaca a concepção de “armas combinadas”. De acordo com House (2008, p. 21) “o conceito de 'combinação das Armas' é a ideia básica de que diferentes Armas combatentes e sistemas de armas devem ser usados em conjunto para maximizar a sobrevivência e a eficácia em combate uma das outras". No cenário contemporâneo, a guerra cibernética é um instrumento de um outro domínio, o ciberespaço, que se destaca como possível campo de afirmação de novas ferramentas no front, mas só produz efeitos cinéticos quando somado ou potencializado por meios de emprego militar convencionais.

Como Clausewitz (2010) argumenta, a violência desferida na guerra se dá por meio da aplicação de meios mais ou menos violentos para atingir objetivos militares, visando alcançar os resultados desejados pela política. À luz dessa afirmação, discorre-se como a combinação entre tecnologia cibernética e força convencional possibilita conquistar objetivos militares. Para tanto, analisa-se o primeiro caso evidente de uso de arma cibernética por e contra um ente estatal: o Stuxnet ${ }^{23}$.

Nos últimos anos, as relações entre Israel e Irã caracterizam-se por tensões provocadas pela retomada do programa nuclear iraniano, visto com ressalvas por outros países do Oriente Médio e pela parceria histórica entre Irã e Hezbollah (THOMAS; HECKER, 2009). Nesse caso, por se tratar de um Estado, os estrategistas israelenses buscaram promover a dissuasão ${ }^{24}$. Para isso, a opção mais destacada

23 A autoria do Stuxnet nunca foi oficialmente comprovada. Todavia, fortes indícios apontam para EUA e Israel (SANGER, 2012; CLARKE; KNAKE, 2015, p. 229-233; FORSLING, 2016).

24 Dissuasão é a capacidade de fazer com que um oponente B desista de realizar uma ação que não seja do interesse de A, pois os custos e riscos não seriam compensados pelos ganhos (MEARSHEIMER, 1983). No entanto, tomam-se, aqui, dissuasão e coerção como elementos complementares (PAPE, 1996). 
foi o uso de uma arma cibernética, sustentada pela possibilidade de recurso a meios de força convencionais.

A dissuasão sempre foi elemento central da política de defesa israelense. Aliada ao que Thomas e Hecker (2009) definem como "excepcionalismo israelense", a dissuasão serviria para "educar" os oponentes nas vezes em que esses tentassem alterar a "regra do jogo". É nesse cenário que a proposta de desenvolvimento de uma arma cibernética se torna atrativa. Em 2010, o governo iraniano torna pública a sabotagem de centrífugas da central nuclear de Natanz (SHAKARIAN, 2011; LOBATO; KENZEL, 2015, p. 27; PORTELA, 2016, p. 94).

De acordo com Langner (2011), a primeira arma cibernética foi desenvolvida exclusivamente para equipamentos Siemens utilizados no programa nuclear iraniano. Em síntese, a sabotagem cibernética foi planejada para infligir danos físicos em uma peça específica. Outra caraterística desse malware é a lentidão em provocar danos, pois não se objetivava parar o programa nuclear iraniano por completo, mas, sim, atrasá-lo.

Descrito como uma arma "atire e esqueça", o Stuxnet foi carregado no sistema operacional das centrífugas de enriquecimento de urânio em Natanz, por meio de pen drive. Porém, ao contrário do que entusiastas da guerra cibernética apregoam, a primeira arma cibernética não foi controlada remotamente, pois, para introduzi-la no sistema iraniano, fez-se necessário o recurso humano (LANGNER, 2011), possivelmente por meio da Inteligência israelense.

Além da falta de provas que poderiam responsabilizar Tel-Aviv ou Washington pelos danos causados pelo Stuxnet, havia a preocupação de que a resposta israelense a uma iniciativa iraniana fosse muito custosa (CLARKE; KNAKE, 2015). Embora o resultado da ação do Hezbollah no Líbano em 2006 possa ter corroborado essa percepção, o fato é que a reação de Teerã se restringiu a manifestações públicas de seu presidente.

Novamente, a impossibilidade de afirmar com clareza quem seriam os responsáveis pelo uso de uma arma ou ataque cibernético prejudica a capacidade de realizar inferências seguras. Entretanto, apesar de o ciberespaço, como domínio militar, ainda não produzir efeitos destrutivos em estruturas estratégicas semelhantes ao uso da força convencional, sua combinação com vetores de força materiais potencializa sua capacidade de causar danos. Dessa forma, a interação entre o domínio cibernético e os demais, bem como sua operação no sentido de armas combinadas, apresenta um panorama estrategicamente interessante quanto à sua incorporação à conduta da guerra, para além das missões de observação, 
reconhecimento, vigilância e inteligência. Ademais, o caso do Stuxnet aponta para a necessidade de se ter uma estratégia comum que combine armas convencionais e cibernéticas, não apenas no sentido ofensivo, mas também no preventivo. Por isso, nessa tendência, vale recuperar o argumento de Libicki (2012, p. 328) sobre a natureza subsidiária do domínio cibernético em relação aos demais.

Como síntese dessa tendência, afirmamos que considerar o ciberespaço como um domínio combatente pode ser, na maioria dos casos, um equívoco. A guerra cibernética se reforça como auxiliar e combina-se a armas convencionais produtoras de efeito cinético, quando não o faz como domínio de apoio aos tradicionais. Ao considerá-lo como domínio, ao invés de atentar para produzir ou negar efeitos estratégicos advindos desse domínio cujas características intrínsecas o tornam fluído e mutável, o projeto e a estratégia das forças são orientados a buscar a superioridade no ciberespaço. Assim, resta uma terceira tendência da guerra cibernética na conduta da guerra.

\section{Terceira tendência: guerra cibernética como arma estratégica}

O terceiro cenário relaciona a compreensão das potencialidades da guerra cibernética à evolução estratégica das nucleares. Apesar de esse campo de investigação ter levado à produção de teorias próprias, em especial às ligadas à dissuasão nuclear, é reconhecida sua origem no âmbito do poder aéreo. Apesar de não vislumbrar um efeito cinético no mesmo nível que o armamento atômico, questiona-se aqui a possibilidade de a guerra cibernética produzir efeitos dissuasórios, tal como as armas nucleares na Guerra Fria. O núcleo dessa lógica é maximizar os benefícios da arma sem usá-la, de forma a prever ou limitar conflitos convencionais.

Em relação ao desenvolvimento da dinâmica de deterrência em torno do campo cibernético, há uma diferença entre o discurso de dissuasão cibernética americano e o israelense (TOR, 2015). No primeiro caso, estadunidenses defendem que dissuadir é influenciar o inimigo mediante uma postura coercitiva, por ser esse um pensamento originário da arma nuclear. Já no segundo, israelenses procuram postergar, limitar e moldar uma série de conflitos, via moderação do inimigo, por meio do emprego limitado da força para controlar o alcance do oponente e adiar a próxima rodada de violência. 
Pensar nessa tendência faz sentido se observar-se a evolução do poder nuclear como derivado do pensamento e da teoria do poder éreo ${ }^{25}$ (FORSLING, 2016). Similar ao ocorrido com as armas nucleares nos anos de 1940 e de 1950, analistas acreditam que o ciberespaço será o principal teatro de operações da guerra do futuro, retirando do combate físico o mecanismo da vitória (BUMILLER; SHANKER, 2012; CLARKE; KNAKE, 2015). Na prática, a compreensão do ciberespaço como vetor de uma revolução militar, como a nuclear, advoga em favor da reestruturação radical das organizações militares para reacomodar essas "novas armas" (COHEN, 2010, p. 147). O militar deve estar atento à quinta dimensão da guerra, a cibernética, para a qual a informação é um ativo estratégico central, além de relacioná-la com as demais. Desse modo, investiga-se, a partir de agora, o ciberespaço como um novo domínio que, como tal, apresenta seus próprios objetivos e obstáculos; logo, examina-se a guerra cibernética enquanto “arma estratégica” (KREPINEVICH, 2012).

Inicialmente, destaca-se a importância de seu maior objetivo, qual seja: buscar a superioridade da informação, entendida, nesse caso, com o mesmo desdobramento que os conceitos de superioridade naval ou aérea defendem. Em síntese, suas metas principais são: proteger a capacidade de coletar, processar e disseminar um fluxo ininterrupto de informações, negando ao adversário o mesmo e cumprindo, assim, requisitos da chamada software warfare (BELLAMY, 2001). Entretanto, para atingir tal fim, deve-se dominar três áreas da guerra na era da informação, a saber: física, informacional e cognitiva. No domínio físico, os elementos de uma força militar devem estar ligados à realização segura e transparente de conectividade e interoperabilidade. No domínio informacional, pessoas e plataformas devem ser capazes de acessar, compartilhar e, mais importante, proteger os dados a um grau que as forças armadas possam estabelecer e manter uma vantagem de informação sobre o adversário. Finalmente, no domínio cognitivo, os militares devem ser capazes de usar essa informação comum para desenvolver a consciência de seu ambiente e compartilhá-la com outros participantes da rede.

Entretanto, a dominância da informação não garante a paralisia estratégica do inimigo, pois a guerra cibernética tem limitações na capacidade de coagir um oponente, caso não seja corroborada por um poder convencional e atuação do espaço físico onde se desdobra força e energia cinética (GARTZKE, 2013; SHELDON, 2011). Como afirmam Thomas e Hecker (2009), esse instrumento não provoca casualidades suficientes para ser considerada guerra e, logo, não consegue ser

25 Principalmente da teoria de bombardeio estratégico (TOR, 2015). 
uma arma dissuasória, como atestam, por exemplo, Clarke e Knake (2015). Neste prisma, a guerra cibernética, tal como empreendida hodiernamente, não permite falar em $C^{2}$ warfare.

O caso mais próximo disso é o Stuxnet, que incidiu ataques, mediante arma cibernética, contra uma usina nuclear, não um centro de $\mathrm{C}^{2}$. Assim, por mais que a guerra cibernética e suas armas se desenvolvam em um território submetido às mesmas leis de manobra, velocidade e unidade de comando que regem os outros domínios, sua capacidade de gerar coerção é praticamente inexistente, se não vir acompanhada por um poder convencional capaz de apoiá-la (GARTZKE, 2013). É a partir dessa consideração que Sheldon (2011) apregoa que a proposta de uma estratégia cibernética é ter a finalidade de criar vantagens e influenciar eventos dentro de seu desenvolvimento operacional e por meio das estruturas tradicionais de poder. Nesse sentido, a guerra cibernética se mostra incapaz de produzir efeitos estratégicos atrelados ao campo nuclear, como a dissuasão ou até mesmo a coerção convencionais.

Para Sheldon (2013), os defensores dessa terceira tendência consideram a possibilidade de, ao menos, duas modalidades de dissuasão a partir do ciberespaço, quais sejam: estratégias punitivas, como a retaliação por meios cibernéticos e/ou respostas militares convencionais; e negação, a exemplo do air gap ${ }^{26}$. Conforme Sheldom (2011) e Gartzke (2013), a dissuasão só pode ser garantida com a combinação de forças convencionais e cibernéticas em torno de um objetivo. Sendo assim, mais uma contradição dos entusiastas que hiperdimensionam tal tendência se destaca: a possibilidade de que nações com poder dissuasório baseado em forças convencionais - em alguns casos, nucleares - possam se ver ameaçadas pela assimetria da guerra cibernética. Tal possibilidade não encontra respaldo diante da incapacidade atual de produção de efeitos dissuasórios ou coercitivos através do ciberespaço. O que ocorre é justamente o contrário, ou seja, países com tal característica reforçam, por meio do uso combinado de forças convencionais e cibernéticas, seu status quo na estrutura de poder regional ou global.

26 Medida de segurança que envolve isolar fisicamente um computador ou rede de computadores, inclusive desconectando-os da internet. 


\section{Conclusões}

O uso estratégico-militar do ciberespaço vem provocando alterações na conduta da guerra. Entretanto, a criação de um novo domínio, o cibernético, não ocorre em desconexão com as dimensões materiais, em que os conflitos armados já se processam. Para melhor avaliar as implicações da guerra cibernética para os estudos estratégicos e de segurança internacional, foram extraídas, da literatura revisada, três tendências que apontam limites e possibilidades para o desenvolvimento desse novo domínio e seu emprego como arma combinada ou vetor estratégico.

O debate hodierno sobre guerra cibernética é caudatário da longa controvérsia que envolve a RAM e seus desdobramentos, ligados à adequação da guerra na era da informação. Em essência, os principais desafios que a guerra cibernética apresenta aos estudos estratégicos na perspectiva clausewitziana são: a eliminação da "fricção" na guerra, a superioridade da ofensiva em detrimento da defesa e, por fim, a guerra não trinitária.

Pode-se afirmar que, até o momento, a literatura não apresenta relatos críveis de que ataques cibernéticos tenham produzido danos em larga escala contra estruturas estratégicas ou centros de $\mathrm{C}^{2}$. Entretanto, apesar de não se atestar vínculos causais, os acontecimentos aqui analisados - envolvendo, ainda que hipoteticamente, Estônia, EUA, Geórgia, Irã, Israel, Rússia e Ucrânia - permitem apregoar que as atuais guerras cibernéticas estão ligadas a retaliações ou antecedem, sem efeitos cinéticos comprovados, ofensivas terrestres contra Estados. É possível ainda declarar, em favor da guerra cibernética, que, quanto mais um país estiver "plugado" ao ciberespaço, especialmente no que tange a suas estruturas estratégicas, mais vulnerável estará para ataques originados no ciberespaço.

Outra conclusão expressa o entendimento de que o ciberespaço e a guerra cibernética são matérias do campo tático, não estratégico. Como arma estratégica, por um lado, a guerra cibernética é incapaz de produzir coerção, em razão das características do ciberespaço e seus limites na produção de efeitos cinéticos. Ao permitir, na maioria das vezes, o anonimato de seus agressores, inviabiliza assim a dissuasão, seja por negação, seja por punição. Por outro lado, constata-se, ainda que preliminarmente, que a superioridade cibernética, quando combinada com avanços conquistados pelas armas convencionais, por meio da RAM ou da transformação militar, pode ser um meio eficaz de se promover vantagens no campo de batalha do século XXI. 
Apesar da oficialização do ciberespaço como domínio de operações pelos EUA e pela OTAN, inclinamo-nos para a tendência da introdução do ciberespaço e de suas armas na acepção de arma combinada. Tal concepção se justifica pelas limitações características da tecnologia cibernética, as quais, quando para fins coercitivos, implicam a necessidade de recorrer a outros domínios para promover desde efeitos cinéticos até mesmo dissuasórios. À luz da teoria clausewitziana, a guerra cibernética merece esse prefixo quando age no meio físico, convertendo-se em recurso para o uso da força.

Finalmente, em virtudes das limitações expostas nesse artigo sobre o impacto revolucionário da guerra cibernética, chama-se atenção para a importância de se pensar, de forma crítica, a incorporação do ciberespaço como novo domínio. Em contrapartida, argumenta-se aqui que tal ceticismo não deve produzir o efeito de negar a realidade da guerra no ambiente cibernético ou de não levá-lo em conta em suas estratégias, especialmente no que toca as potencialidades de emprego como arma combinada.

\section{Referências}

ANDREWS, Timothy D. Revolution and evolution: understanding dynamism in military affairs. Washington, DC: NDU Press, 1998, p. 4-40. Disponível em: http://www.iwar. org.uk/rma/resources/rma/98-E-27.pdf. Acesso em: 23 abril 2017.

BAE SYSTEMS. Snake Rootkit Report 2014. London: BAE Systems, 2014. Disponível em: http://info.baesystemsdetica.com/rs/baesystems/images/snake_whitepaper.pdf. Acesso em: 11 out. 2016.

BELLAMY, Christopher. What is information warfare?. In: MATTHEWS, Ron; TREDDENICK, John (Org.). Managing the revolution in military affairs. New York, NY: Palgrave, 2001. BIDDLE, Stephen. Iraq, Afghanistan, and American military transformation. In: BAYLIS, John; WIRTZ, James J.; GRAY, Colin S. (Org.). Strategy in the contemporary world: an introduction to Strategic Studies. 3. ed. Oxford, NY: OUP, 2010.

BIRDWELL, M. Bodine; MILLS, Robert. War fighting in cyberspace: evolving force presentation and command and control. Air \& Space Power Journal, p. 26-36, Spring 2011. BOHN, Eduardo C.; NOTHEN, Maurício R. Considerações sobre o ciberespaço e sua inserção nos Estudos Estratégicos. In: GUEDES DE OLIVEIRA, Marcos A.; GAMA NETO, Ricardo B.; VILAR LOPES, Gills (Org.). Relações Internacionais Cibernéticas (CiberRI): oportunidades e desafios para os Estudos Estratégicos e de Segurança Internacional. Recife: Editora da UFPE, 2016. (Defesa \& Muros Virtuais, 3). 
BRZEZINSKI, Zbigniew K. EUA $x$ URSS: o grande desafio. Rio de Janeiro: Editorial Nórdica, 1989.

BUMILLER, E.; SHANKER, Thom. Panetta warns of dire threat of cyberattack on U.S. The New York Times, New York, 11 out. 2012. World, p. A1. Disponível em: http:// www.nytimes.com/2012/10/12/world/panetta-warns-of-dire-threat-of-cyberattack. html. Acesso em: 22 dez. 2017.

SPUTINIK. China cria ramo das Forças Armadas sem análogos no mundo. Sputnik, 18 jan. 2016. Disponível em: http://br.sputniknews.com/mundo/20160118/3325675/Chinatropas-unicas-reforma-militar.html. Acesso em: 7 jun. 2016.

CLARKE, Richard A.; KNAKE, Robert K. Guerra cibernética: a próxima ameaça à segurança e o que fazer a respeito. Tradução de: Bruno S. Guimarães et al. Rio de Janeiro: Brasport, 2015.

CLAUSEWITZ, Carl von. Da guerra. Tradução de: Maria Tereza Ramos. 3. ed. São Paulo: Martins Fontes, 2010. (Clássicos Martins Fontes).

COHEN, Eliot. Technology and warfare. In: BAYLIS, John; WIRTZ, James J.; GRAY, Colin S. (Org.). Strategy in the contemporary world: an introduction to Strategic Studies. 3. ed. Oxford, NY: OUP, 2010.

CROFT, Adrian; APPS, Peter. NATO websites hit in cyber attack linked to Crimea tension. Reuters, Brussels, 16 mar. 2014. Disponível: http://www.reuters.com/article/2014/ 03/16/us-ukraine-nato-idUSBREA2E0T320140316. Acesso em: 11 out. 2015.

DAVIS, Paul K. Military Transformation? Which Transformation, and What Lies Ahead? Santa Monica, CA: RAND Corporation, 2010.

ESTADOS UNIDOS DA AMÉRICA. US Cyber Command (USCYBERCOM). Washington: United States Strategic Command, 2016. Disponível em: http://www.stratcom.mil/ Media/Factsheets/Factsheet-View/Article/960492/us-cyber-command-uscybercom. Acesso em: 31 out. 2016.

FORSLING, Carl. Should cyber warfare have its own branch? Task and purpose, 28 jun. 2016. [online]. Disponível em: http://taskandpurpose.com/cyber-warfare-branch. Acesso em: 3 ago. 2016.

GAMA NETO, Ricardo B.; VILAR LOPES, Gills. Armas cibernéticas e segurança internacional. In: MEDEIROS FILHO, Oscar et al. (Org.). Segurança e defesa cibernética: da fronteira física aos muros virtuais. Recife: Editora da UFPE, 2014. (Defesa \& Muros Virtuais, 1). GARTZKE, Erik. The myth of cyberwar: bringing war in cyberspace back down to Earth. International Security, v. 38, n. 2, p. 41-73, Fall 2013. Disponível em: https://www. belfercenter.org/sites/default/files/files/publication/IS3802_pp041-073.pdf. Acesso em: 22 dez. 2017.

GEORGE, Alexander L.; BENNETT, Andrew. Case studies and theory development in Social Sciences. Cambridge: MIT Press, 2005. 
HOUSE, Jonathan M. Combinação das armas: a guerra do século XX. Rio de Janeiro: Biblioteca do Exército Editora, 2008.

JONES, Sam. Kremlin alleged to wage cyber warfare on Kiev. Financial Times, 5 jun. 2014. Cyber. Disponível: http://www.ft.com/intl/cms/s/0/e504e278-e29d-11e3-a82900144feabdc0.html. Acesso em: 11 ago. 2016.

KASPERSEN, Anja. Cyberspace: the new frontier in warfare. World Economic Forum, 24 set. 2015. Disponível em: https://www.weforum.org/agenda/2015/09/cyberspacethe-new-frontier-in-warfare. Acesso em: 2 ago. 2016.

KREPINEVICH, Andrew F. Cyber warfare: a "nuclear option"? Washington, DC: CSABA, 2012.

LANDMAN, Todd. Issues and methods in Comparative Politics: an introduction. 3. ed. New York, NY: Routledge, 2008.

LANGNER, Ralph. Stuxnet: dissecting a cyberwarfare weapon. Focus, maio-jun. 2011, p. 49-51. Disponível em: http://wp. vcu.edu/hsep/wp-content/uploads/sites/3338/ 2013/06/stuxnet.pdf. Acesso em: 6 abr. 2017.

LEE, Dave. Rússia e Ucrânia travam ‘duelo cibernético’. BBC Brasil, 7 mar. 2014. Disponível em: http://www.bbc.co.uk/portuguese/noticias/2014/03/140307_russia_ucrania_ bg.shtml. Acesso em: 11 ago. 2016.

LIBICKI, Martin C. Cyberspace is not a warfighting domain. I/S: a Journal of Law and Policy for the Information Society, v. 8, n. 2, p. 321-336, 2012.

LILES, Samuel; et a.. Applying traditional military principles to cyber warfare. In: C. CZOSSECK; OTTIS, R.; ZIOLKOWSKI, K. (Ed.) $4^{\text {th }}$ International Conference on Cyber Conflict. Tallinn: NATO CCD COE Publications, 2012.

LOBATO, Luísa Cruz; KENKEL, Kai M. Discourses of cyberspace securitization in Brazil and in the United States. Revista Brasileira de Politica Internacional, v. 58, n. 2, 2015, p. 23-43. Disponível em: http://www.scielo.br/pdf/rbpi/v58n2/0034-7329rbpi-58-02-00023.pdf. Acesso em: 22 abr. 2017.

MACISAAC, David. Vozes do azul: teóricos do Poder Aéreo. In: PARET, Peter (Org.). Construtores da estratégia moderna: de Maquiavel à era nuclear. Tomo 2. Tradução de Joubert de O. Brízida. Rio de Janeiro: Biblioteca do Exército Editora, 2003.

MEARSHEIMER, John J. Conventional deterrence. Cornell: Cornell University Press, 1983. MINÁRIK, Tomáš. NATO Recognises Cyberspace as a "Domain of Operations" at Warsaw Summit. NATO CCDCOE, Tallinn, 21 jul. 2016. Disponível em: https://ccdcoe.org/ nato-recognises-cyberspace-domain-operations-warsaw-summit.html. Acesso em: 28 out. 2016.

NYE JR, Joseph S. Cyber insecurity. Daily News Egypt, Cambridge, 14 dez. 2008. Disponível em: http://belfercenter.ksg.harvard.edu/publication/18727/cyber_insecurity.html. Acesso em: 1 out. 2016. 
OPPERMANN, Daniel. Virtual attacks and the problem of responsibility: the cases of China and Russia. Carta int., São Paulo, v. 5, n. 2, NUPRI-USP, dez. 2010, p. 11-25. Disponível em: http://citrus.uspnet.usp. br/nupri/arquivo.php?id=21. Acesso em: 30 mar. 2016.

PAPE, Robert. Bombing to win: Air Power and coercion in war. Cornell: Cornell University Press, 1996.

PERON, Alcides E. dos R. Guerra virtual e eliminação da fricção? O uso da cibernética em operações de contrainsurgência pelos EUA. In: GUEDES DE OLIVEIRA, Marcos A.; GAMA NETO, Ricardo B.; VILAR LOPES, Gills (Org.). Relações Internacionais Cibernéticas (CiberRI): oportunidades e desafios para os Estudos Estratégicos e de Segurança Internacional. Recife: Editora da UFPE, 2016. (Defesa \& muros virtuais, 3). PORTELA, Lucas S. Agenda de pesquisa sobre o espaço cibernético nas Relações Internacionais. Revista Brasileira de Estudos de Defesa, v. 3, n. 1, jan./jun. 2016, p. 91-113. Disponível em: http://seer.ufrgs.br/index.php/rbed/article/view/62071. Acesso em: 20 abr. 2017.

PROENÇA JR, Domício. Promessa tecnológica e vantagem combatente. Revista Brasileira de Política Internacional, v. 54, n. 2, 2011, p. 173-188. Disponível em: http://www. scielo.br/pdf/rbpi/v54n2/v54n2a09.pdf. Acesso em: 22 dez. 2017.

PROENÇA JR, Domício; DINIZ, Eugenio; RAZA, Salvador G. Guia de estudos de estratégia. Rio de Janeiro: Jorge Zahar Editor, 1999.

SANGER, David E. Confront and conceal: Obama's secret wars and surprising use of American power. New York: Crown: 2012.

SHAKARIAN, Paulo. Stuxnet: Cyberwar Revolution in Military Affairs. Small Wars Journal, 15 April 2011. Disponível em: < http://smallwarsjournal.com/blog/journal/docstemp/734-shakarian3.pdf > . Acesso em: 16 ago. 2016.

SHELDON, John B. Deciphering cyberpower strategic purpose in peace and war. Strategic Studies Quarterly, Summer 2011, p. 95-112. Disponível em: http://www.au.af.mil/ au/ssq/2011/summer/sheldon.pdf. Acesso em: 22 dez. 2017.

SHELDON, John B. The rise of cyberpower. In: BAYLIS, John; WIRTZ, James J.; GRAY, Colin S. (Org.). Strategy in the contemporary world: an introduction to Strategic Studies. 4. ed. Oxford, NY: Oxford University Press, 2013.

SLOAN, Elinor C. Modern military strategy: an introduction. Oxon, NY: Routledge, 2012. THOMAS, Rid; HECKER, Marc. War 2.0: irregular warfare in the Information Age. Wesport: Praeger, 2009.

TOR, Uri. 'Cumulative deterrence' as a new paradigm for cyber deterrence. Journal of Strategic Studies. Vol. 0, Iss. 0, p. 1-26, 18 dez. 2015. Disponível em: http://www. tandfonline.com/doi/abs/10.1080/01402390.2015.1115975?journalCode $=$ fjss20 Acesso em: 22 dez. 2017.

VAN EVERA, Stephen. Guide to methods for students of Political Science. Cornell: Cornell University Press, 1997. 


\title{
As disputas sino-vietnamitas no Mar do Sul: desafios para além da questão regional $^{1}$
}

\section{The sino-vietnamite disputes in the South Sea: challenges beyond the regional issue}

DOI: $10.21530 /$ ci.v12n3.2017.679

\author{
Diego Pautasso ${ }^{2}$ \\ Alexandre Cesar Cunha Leite ${ }^{3}$ \\ Gaio Doria ${ }^{4}$
}

\section{Resumo}

O presente artigo tem por objetivo analisar a situação atual das relações entre a China e o Vietnã na questão relativa às disputas territoriais no Mar do Sul da China. Por um lado, China e Vietnã convergem em seus regimes políticos e modelos econômicos, além de participar de processos de integração regional conjuntos. Por outro, possuem interesses políticos e territoriais divergentes sobre espaços no Mar do Sul da China, região estratégica nos âmbitos comercial e geopolítico. Trata-se de um dos litígios territoriais mais importantes envolvendo os países da região e seus potenciais aliados, com destaque para a forte penetração dos Estados Unidos (EUA). É, pois, um tema complexo que engloba questões militares, econômicas e diplomáticas, com desdobramentos para o sistema internacional. O argumento proposto é que esse litígio tende a determinar não apenas a evolução das relações bilaterais sino-vietnamitas, mas a dinâmica de integração regional e, sobretudo, a projeção de poder dos Estados Unidos em uma porção chave do mundo oriental.

Palavras-chave: China, Vietnã, Mar do Sul da China, Disputas Territoriais.

\footnotetext{
Abstract

The purpose of this article is to analyze how relations between China and Vietnam derive from territorial disputes in the South China Sea. On the one hand, China and Vietnam have convergent political regimes and economic models, and participate in joint regional integration

1 Os autores agradecem os comentários e sugestões dos pareceristas anônimos. Como de praxe, todas as informações e opiniões contidas no artigo são, exclusivamente, de responsabilidade dos autores.

2 Departamento de Relações Internacionais da Universidade do Vale do Rio Sinos (UNISINOS), São Leopoldo/RS, Brasil. E-mail: dgpautasso@gmail.com

3 Programa de Pós-Graduação em Relações Internacionais da Universidade Estadual da Paraíba (UEPB) e Programa de Pós-Graduação em Gestão Pública e Cooperação Internacional da Universidade Federal da Paraíba (UFPB), João Pessoas/Paraíba, Brasil. E-mail: alexccleite@gmail.com.

4 Universidade do Povo da China em Beijing, China. E-mail: gaiodoria@gmail.com

Artigo submetido em 31/05/2017 e aprovado em 24/08/2017.
} 
processes. On the other hand, they have divergent political and territorial interests over spaces in the South China Sea, a strategic region in the commercial and geopolitical spheres. This is one of the most important territorial disputes, involving the countries of the region and their potential allies, especially the strong penetration of the United States. Is therefore a complex subject that encompasses military, economic, and diplomatic issues, with consequences for the international system? The argument is that this litigation tends to determine not only the evolution of Sino-Vietnamese bilateral relations, but the dynamics of regional integration and, above all, the projection of US power into a key portion of the oriental world.

Keywords: China, Vietnam, South China Sea, Territorial Disputes.

\section{Introdução}

As relações entre China e Vietnã têm sido marcadas por dinâmicas convergentes e divergentes. São países que preservam regimes políticos liderados por partidos comunistas e, não obstante, os debates acerca da natureza de seus modelos econômicos, são autodefinidos por seus próprios governos como formas de socialismo onde há o mecanismo de mercado. O partido comunista do Vietnã define o atual sistema econômico como uma economia de mercado de orientação socialista, enquanto o partido comunista da China prefere o termo socialismo de mercado.

Apesar dessa identidade política, as disputas no Mar do Sul da China têm fortalecido as rivalidades bilaterais, entre o grupo de países da região costeira; redefinindo o padrão de alianças e relações na região. Trata-se, como se pode observar pelos números que seguem, de uma região estratégica: i) reservas de 11 bilhões de barris de óleo e 190 trilhões de metros cúbicos de gás natural; ii) rota marítima de extrema importância, por onde passam cerca de U\$5,3 trilhões de dólares do total anual de comércio do mundo e onde estão metade dos 50 maiores portos do mundo5; e iii) alto potencial de exploração dos demais recursos naturais do mar. É uma das regiões com maior potencial de escalada de violência, pois os litígios territoriais sino-vietnamitas e a penetração da grande potência hegemônica, os Estados Unidos, doravante EUA, tornam o equilíbrio de forças muito mais delicado (BUSZYNSKI, 2012).

A compreensão dessa temática ganha complexidade visto que os estudos de segurança possuem fraquezas e pontos cegos, frutos de um viés anglocêntrico

5 Ver detalhes no site da World Shipping disponível em: http://www.worldshipping.org/about-the-industry/ global-trade/top-50-world-container-ports 
(BUZAN; HANSEN, 2012), mas também dada a existência de novas abordagens que dão conta da cosmologia oriental. Cabe lembrar que no sistema sinocêntrico asiático não havia noções de soberania e igualdade jurídica entre as nações; também não havia excepcionalismo universalista nem ambições territoriais ao estilo estadunidense (KANG, 2003). De maneira arguta, Kissinger (2011, p. 40-42) compara o jogo chinês wei qi com o xadrez e Sun Wu com Clausewitz para ilustrar as diferentes formas de pensar e agir. Logo, percebe-se que o tema é complexo não somente pela quantidade de atores dispersos no tabuleiro regional e pelo número de disputas em jogo, mas por requerer parcimônia para lidar com essas heranças culturais e políticas tradicionais como novas acomodações oriundas de lógicas modernas, entendidas como os Estados nacionais e a economia de mercado capitalista.

Para a China, está posto o objetivo de evitar a política estadunidense voltada a fomentar as tensões para legitimar sua presença e, quiçá, usar uma eventual escalada belicosa como forma de conter a ascensão chinesa. A obsessão chinesa tem sido o desenvolvimento nacional que, por sua vez, depende da preservação da estabilidade regional e mesmo global. Em outras palavras, o entrelaçamento entre desenvolvimento e segurança está claro para o governo chinês; e, por isso, todas as provocações serão meticulosamente calculadas. O Vietnã, por sua vez, não desconhece a centralidade da China, mas busca estreitar relações com os EUA para equilibrar as negociações e garantir certa estabilidade na região.

Para compreender tal problemática, o artigo busca analisar, primeiramente, a política externa chinesa e sua projeção regional. Segundo, aborda-se o papel do Vietnã, em suas relações tensas e contraditórias com a China e os EUA. Por fim, o objetivo é compreender como os EUA buscam explorar as rivalidades sinovietnamitas para projetar poder na região a partir dos conflitos territoriais no Mar do Sul da China.

\section{Ascensão chinesa e o entorno regional}

As reformas econômicas e políticas implementas pela China comunista na década de 1970 alçaram o país ao patamar de segunda maior economia do mundo no início do século XXI e à maior, quando medida em paridade de poder de compra em 2015, com 19,8 trilhões de dólares contra 18 trilhões dos EUA6 ${ }^{6}$.

6 Ver dados oficiais do Banco Mundial: http://data.worldbank.org/data-catalog/GDP-PPP-based-table 
As novas capacidades econômicas, política e militares do gigante asiático alteraram sua posição na ordem internacional vigente e as configurações de poder no mundo. É notório que o potencial militar chinês vem crescendo quase que proporcionalmente ao seu desempenho econômico, fortalecendo seu engajamento em assuntos de segurança, na dinâmica de integração econômica da Ásia e nos investimentos na África e na América Latina, na criação de instituições alternativas ao sistema financeiro vigente, entre outras iniciativas. Inegavelmente, a ascensão da China aparece no horizonte como um claro desafio à ordem internacional atualmente liderada pelos EUA - embora a China ainda esteja em uma fase onde busca primeiramente diminuir o atraso tecnológico em face da grande potência hegemônica.

Com o intuito de se contrapor a essa visão, oficiais do governo e acadêmicos chineses formularam a ideia de desenvolvimento pacífico e da construção de um mundo harmonioso (和平发展与构建和谐世界), conceito apresentado ainda em 2005 por Hu Jintao e depois consolidado no $17^{\circ}$ Congresso do Partido Comunista da China (2007). E, desde meados de 2005, a China concentrou-se em introduzir o conceito de harmonia (和谐) na sua política externa. Esse é um dos pilares fundamentais do pensamento confuciano no tocante à governança. A ideia, no entanto, foi inserida no arcabouço teórico do partido comunista da China oficialmente durante o governo do presidente Hu Jintao. Esse apontava a necessidade de uma "sociedade harmoniosa" como um objetivo para o futuro do desenvolvimento socioeconômico da China. Em setembro de 2005, Hu conclamou a necessidade de um "mundo harmonioso" em seu discurso no encontro em homenagem ao $60^{\circ}$ aniversário da fundação das Nações Unidas 7 . Logo em seguida, ainda no mesmo ano, o governo chinês publicou um documento intitulado “O caminho para o desenvolvimento pacífico da China” (中国和平发展道路), onde expõe o papel positivo do crescimento chinês na busca pelo ideal nobre da paz e do desenvolvimento da humanidade como um todo (Xinhuanet, 2005).

O novo conceito de segurança (新安全观) tem buscado integrar as questões securitárias às concepções históricas chinesas, avessas ao emprego da força como recurso prioritário. Conforme o documento publicado pelo Ministério das Relações Exteriores, "na visão da China, o cerne deste novo conceito de segurança deve incluir confiança mútua, benefício mútuo, igualdade e coordenação” (MINISTRY OF FOREIGN AFFAIRS OF THE PEOPLE'S REPUBLIC OF CHINA, 2012). Como

7 Ver http://www.un.org/webcast/summit2005/statements15/china050915eng.pdf 
destaca Gill (2007), a política chinesa dedica atenção aos mecanismos de segurança regional e à defesa da soberania face intervenções estrangeiras - justamente o que atravessa os litígios no Mar do Sul da China.

No bojo desse debate, um proeminente membro do partido comunista da China, Zheng Bijian, cunhou, em 2003, o conceito de "ascensão pacífica" da China (中国和平崛起), ao dizer que “a única opção da China é se esforçar para ascender e, mais importante, para lutar por uma ascensão pacífica” (ZHENG, 2005, p. 14-19). Esse conceito gerou controvérsias na elite dirigente chinesa. Alguns nacionalistas o acharam equivocado, pois sinalizava que um eventual movimento independentista (Taiwan ou Tibete) ou disputa territorial seria tolerada. Outros pensavam que o conceito provocava desconfiança nos vizinhos por reafirmar a ideia de "ascensão". A controvérsia em torno do termo ascensão empurrou a liderança chinesa a trocar as palavras, mas mantendo a ideia principal. Em 2004, no Fórum Boao, o então presidente Hu Jintao usou o desenvolvimento pacífico da China (中国和平发展) como substituto. Desde então, esse tem sido o jargão mais utilizado nos documentos oficiais. ${ }^{8}$

O fato é que tem ocorrido atualizações nos conceitos de política externa ao longo das quatro últimas gerações de liderança coletiva do PCCh. É inegável, contudo, que os Cinco Princípios de Coexistência Pacífica - nomeadamente, respeito mútuo a integridade territorial e soberania; não agressão mútua; não interferência nos assuntos internos; igualdade; benefício mútuo e coexistência pacífica - foram concebidos pela China para resolver a questão da convivência com países não socialistas e para equacionar questões pendentes do ponto de vista histórico (LI, 2012). Inicialmente proposta por Zhou Enlai para reduzir a tensão existente derivada da questão entre a China e a Índia no tocante ao Tibete, passou do âmbito das relações bilaterais para a esfera internacional através da Conferência Afro-Asiática realizada em Bandung, na Indonésia em 1955. Essa foi a base da Conferência de Bandung, cujo mote se resumiu a dez pontos sobre "a promoção da paz e cooperação mundiais", e de outros mecanismos multilaterais como o Movimento dos Não Alinhados e o G-77. Representou, sem dúvida, uma nova etapa na história mundial, sendo a origem das relações Sul-Sul e sua organização em torno de princípios, valores e ideias comuns (PEREIRA; MEDEIROS, 2015).

Além disso, o binômio paz e desenvolvimento não é original da terceira geração da liderança do PCCh. Deng Xiaoping, em 1985, já problematizava a

8 Ver http://english.boaoforum.org/document2004/11119.jhtml 
questão da interpretação da ascensão chinesa, utilizando conceitos que iriam se tornar chave no discurso chinês nas décadas seguintes, tais como relação Sul-Sul, “anti-hegemonismo", dentre outros. Deng é categórico ao afirmar que "quando a hora chegar, a China certamente irá desempenhar um grande papel na manutenção da paz e estabilidade mundial” (DENG, 1994, p. 110-112).

É com os desdobramentos históricos e político-diplomáticos, com as intrínsecas contradições e conflitos de interesses e direitos, que se poderá captar a verdadeira natureza da ascensão chinesa. Nesse sentido, a questão do Mar do Sul assume uma importância singular. O número de países que clamam soberania sobre a região, a partilha das reservas de recursos naturais e a complexidade em acomodar as diversas disputas serão um grande desafio para a resolução do imbróglio. E, naturalmente, o envolvimento da superpotência estadunidense recrudesce a complexidade da questão. Dessa forma, a consolidação da China como líder regional e potência mundial passa por saber conduzir tais litígios - que, por extensão, são essenciais para sua integridade territorial, segurança energética, integração regional e comércio exterior.

As disputas no Mar do Sul envolvem diversas ilhas e zonas econômicas exclusivas (mar territorial) entre diversos países da região, nomeadamente a República Popular da China, a República da China (Taiwan), Filipinas, Vietnã, Brunei e Malásia. A República Popular da China possui as maiores aspirações em termos territoriais - almeja uma área definida através do conceito de "linha de nove-traços” (九段线) (originalmente, “linha dos onze-traços”), proposta pela República da China durante o governo do Guomindang, com ajuda técnica dos EUA, antes da derrota para os comunistas, em 1947, com intuito de reivindicar soberania sob as ilhas Paracels, Prats e Spratly, logo após a rendição japonesa na Segunda Guerra (FRAVEL, 2011).

O imbróglio aumentou quando o Tratado de São Francisco (1951), que dispôs sobre a situação do Japão no pós-guerra, não resolveu a questão das ilhas, deixando a República Popular da China (RPC) e a República da China (Taiwan) de fora de qualquer negociação. Os comunistas emitiram notas de repúdio e, posteriormente, o premier Zhou Enlai subtraiu dois traços, retirando o Golfo de Tonkin e formando a "linha de nove-traços", que a China reivindica atualmente.

Segundo a entrevista concedida ao Consensus Net por Xue Li (LI, 2016), chefe da Divisão Estratégica Internacional do Instituto de Economia e Política Mundial da Academia de Ciências Sociais da China, não existe consenso entre os acadêmicos chineses sobre o assunto. Há, todavia, quatro grandes interpretações 
sobre o significado da "linha dos nove-traços": demarcação de fronteiras marítimas, soberania sobre as ilhas, direitos históricos e águas históricas.

O governo chinês adota como posição oficial os direitos históricos sobre a região, pois argumenta que as atividades dos chineses no Mar do Sul da China datam de mais de dois mil anos. A China teria sido a primeira a descobrir, nomear e se dedicar à exploração e ao aproveitamento das ilhas localizadas no Mar do Sul, além de ter sido a primeira a exercer soberania e jurisdição sobre elas de forma contínua, pacífica e eficaz. Segundo o recente Livro Branco, publicado pelo Gabinete de Imprensa do Conselho de Estado da China envolvendo a questão, há numerosos documentos históricos para comprar essa afirmação, tais como o "Yi Wu Zhi (Relato de Coisas Estranhas) da dinastia Han do Leste (25-220); Fu Nan Zhuan (Registro de Fu Nan) do Período dos Três Reinos (220-280); Meng Liang Lu (Registro de um Sonhador Acordado) e Ling Wai Dai Da (Notas sobre as Ilhas além das Passagens) da dinastia Song (960-1279); Dao Yi Zhi Lüe (Breve Relato das Ilhas) da dinastia Yuan (1271-1368); Dong Xi Yang Kao (Estudos sobre Oceanos do Leste e do Oeste) e Shun Feng Xiang Song (Bom Vento para Escolta) da dinastia Ming (1368-1644); assim como Zhi Nan Zheng Fa (Navegações com Bússola) e Hai Guo Wen Jian Lu (Registros de Coisas Vistas e Ouvidas sobre as Regiões Costeiras) da dinastia Qing (1644-1911)" (GABINENTE DE IMPRENSA DO CONSELHO DE ESTADO DA CHINA, 2016). São esses documentos que legitimam as assertividades chinesas na região, buscando respaldar a Lei sobre o Mar Territorial e Zonas Contíguas de 1992 e dirimir a disputa sobre as ilhas e territórios reivindicados no Mar do Sul.

Naturalmente, os vizinhos possuem suas narrativas e embasamentos históricos, jurídicos e políticos. É o caso das Filipinas, que em junho de 2016 encaminharam - e tiveram aceita - ao Tribunal Permanente de Arbitragem de Haia sua demanda de exploração de recursos no Mar do Sul da China. Segundo o tribunal, não procedem as alegações chinesas acerca das "evidências históricas" de seu controle sobre aquela região. Mesmo que tivesse direitos históricos sobre as águas do Mar do Sul, esses direitos foram extintos pois são incompatíveis com as zonas econômicas exclusivas estabelecidas pela Convenção das Nações Unidas de 1982 sobre o Direito do Mar9.

9 Ver documento oficial da corte disponível em: https://pca-cpa.org/en/news/pca-press-release-the-south-chinasea-arbitration-the-republic-of-the-philippines-v-the-peoples-republic-of-china/ 
Ao que parece, a China já esperava uma resposta negativa, pois, no dia 5 de junho de 2016, no Diálogo China-EUA sobre o Mar do Sul da China entre think tanks chineses e estadunidenses, em Washington D.C, o diplomata chinês veterano Dai Bingguo afirmou que "adjudicação definitiva da arbitragem, que sairá nos próximos dias, equivale a nada mais do que um pedaço de papel” (DAI, 2016).

E mesmo antes da decisão oficial ser publicada, o jornal Global Times já havia escrito um editorial avisando que a reação da China iria depender da provocação das demais partes envolvidas, defendendo que "o povo e governo chineses compartilham dos mesmos interesses e responsabilidades. Nós devemos não apenas salvaguardar a soberania territorial, como também realizar esforços máximos para manter a paz na periferia da China, prolongando as oportunidades estratégicas para a ascensão da China" (GLOBAL TIMES, 2016). Após o veredicto, governo chinês - que havia boicotado as audiências em Haia por não reconhecer a jurisdição do tribunal sobre a disputa - declarou "solenemente que o veredicto é nulo e não possui força vinculativa” (MINISTÉRIO DAS RELAÇÕES EXTERIORES DA CHINA, 2016).

O país asiático reafirma que "em relação às questões territoriais e disputas de delimitação marítima, a China não aceita qualquer meio de solução de disputas por terceiros ou qualquer solução imposta à China" (MINISTÉRIO DAS RELAÇÕES EXTERIORES DA CHINA, 2016). Em outras palavras, prefere realizar as negociações no âmbito das relações bilaterais conforme estabelecido na Declaração de Conduta das Partes no Mar do Sul da China, assinada em 2002 com dez países membros da Associação das Nações do Sudeste Asiático (ASEAN) ${ }^{10}$. Em março de 2016, o vice-ministro de Relações Exteriores da China, Liu Zhenmin, reafirmou tal posição ao declarar que "alguns países gostam de trazer à tona a questão do Mar do Sul da China nos fóruns multilaterais. O propósito verdadeiro deles não é resolver o problema, mas jogar com ele. Isto fez com que a questão do Mar do Sul da China se torne suscetível à exploração externa” (LIU, 2016).

O Livro Branco, publicado em janeiro de 2017, intitulado Sobre a Política Chinesa na área de Cooperação de Segurança na Ásia-Pacífico ${ }^{11}$, revela em detalhes as posições do governo chinês sobre o tema. O texto, através do discurso padrão do governo chinês, ilustra os aspectos positivos das cooperações regionais realizadas

10 Ver íntegra do documento da ASEAN no site oficial, disponível em: http://asean.org/?static_post = declarationon-the-conduct-of-parties-in-the-south-china-sea-2

11 Ver íntegra do documento oficial do governo da RPC, disponível em: http://news.xinhuanet.com/english/ china/2017-01/11/c_135973695.htm 
até agora no assunto. No entanto, o real significado desse documento é estabelecer o quadro teórico para a consolidação da China enquanto uma potência regional, cujo principal obstáculo é a tendência dos países pequenos em procurar alianças com as grandes potências para contrabalancear a ascensão chinesa, trazendo atores extrarregionais para a equação.

No tocante à questão do Mar do Sul, por muito tempo a China foi acusada de buscar a resolução das disputas em espaços bilaterais. Em 2014, o ministro de Relações Exteriores Wang Yi apresentou a ideia da "dupla abordagem”, sinalizando que a China aceitaria lidar com as disputas sobre o Mar do Sul na ASEAN, um espaço multilateral ${ }^{12}$. A aceitação chinesa da regionalização da questão pressupõe o impedimento da internacionalização da contenda com a participação de atores extrarregionais, leia-se a superpotência (EUA), com sua enorme capacidade de influenciar o quadro de forças na região, fomentando a escalada de violência e a desestabilização dos países envolvidos na questão.

\section{Vietnã entre gigantes}

Do ponto de vista teórico, existem duas perspectivas de análise para interpretar as dinâmicas das relações sino-vietnamitas. A primeira assume a primazia de fatores históricos sedimentados no longo prazo que interligam esses dois países asiáticos. O Vietnã assimilou diversos elementos da cultura chinesa por aproximadamente dez séculos (de 3 a.C até 10 d.C), período onde esteve condicionado ao domínio chinês. Essa fase de dominação é interpretada como um momento de fraqueza que somente é superado com a expulsão dos chineses, fato celebrado na historiografia vietnamita (SHARROCK; LIEN, 2014).

A segunda assume a posição geográfica, os conflitos ideológicos e a dinâmica geopolítica. Durante o século XX, o Vietnã e a China, apesar de comungarem de regimes políticos semelhantes, apresentaram diversas contradições, em especial devido à correlação de forças entre a União Soviética e os Estados Unidos. Como aponta Ang Cheng Guan (1998), as duas perspectivas não são excludentes, ao contrário, história e geopolítica são variáveis importantes nas relações sino-vietnamitas. 
As relações entre China e Vietnã têm sido marcadas por cooperação e competição. Durante grande parte da guerra de agressão imperialista contra o Vietnã, ocorrida entre 1 de novembro de 1955 até a queda de Saigon em 30 de abril de 1975, a China proveu um apoio considerável ao país vizinho. No entanto, ao longo da década de 1970, as relações entre os dois países asiáticos começaram a deteriorar-se rapidamente. Por um lado, a adesão do Vietnã ao mecanismo de integração econômica dos países socialistas, o Comecon (Council for Mutual Economic Assistance) e a assinatura de um tratado de cooperação e amizade com a União Soviética, ambos em 1978, irritaram profundamente os chineses. Por outro, a reaproximação chinesa com os Estados Unidos e a posterior normalização das relações sino-estadunidenses em 1979 tampouco agradaram os vietnamitas. No ano de 1978, os chineses cortaram o envio de recursos ao Vietnã. Em um contexto histórico onde o racha sino-soviético dividia o bloco comunista em esferas de influência, as tensões entre os dois estados comunistas acabaram culminando em um conflito armado. Por um lado, os chineses apoiaram as provocações do regime antivietnamita de Pol Pot do Camboja na fronteira entre os dois países. Enquanto isso, como já mencionamos parcialmente, o Vietnã assinava acordos com Laos e a arquirrival chinesa, a URSS, em 1977. As rusgas regionais culminaram na guerra do Vietnã contra Camboja e China. Por outro lado, na década de 1980, as reformas da China serviram de inspiração para a política Doi Moi, ou "renovação", cujo objetivo foi seguir numa linha próxima ao socialismo de mercado chinês (VISENTINI, 2012, p. 156-60). Isto é, não há como subestimar as vicissitudes geopolíticas que permearam as relações sino-vietnamitas no século XX (QIANG 2005).

Após o colapso do campo soviético, a China tornou-se central para preservar as heranças do campo socialista. Isso fez com que muitos dos países socialistas reminiscentes adotassem políticas inspiradas no caminho chinês. No entanto, na perspectiva do Vietnã, a ascensão chinesa como potência econômica em busca de hegemonia regional gera profundas contradições, dadas suas capacidades tecnológicas, financeiras e comerciais completamente assimétricas diante de seus vizinhos do Sudeste Asiático. No Livro Branco intitulado O desenvolvimento pacífico da China, publicado em 2011, o governo chinês detalha seus interesses fundamentais, nomeadamente soberania estatal, segurança nacional, integridade territorial, reunificação nacional, manutenção do sistema político estabelecido pela constituição e salvaguardar o desenvolvimento sustentável econômico e social ${ }^{13}$. 
Consequentemente, as recentes disputas da China no Mar do Sul assumem um caráter estratégico, pois tratam-se de questões de soberania estatal, segurança nacional e integridade territorial. Disputa na qual o Vietnã é uma das partes interessadas.

Já a estratégia do governo do Vietnã tem incluído aproximar-se dos EUA, tanto para fazer um contrapeso à hegemonia regional chinesa quanto para ampliar sua inserção internacional. Não é novidade na história contemporânea do Vietnã a capacidade de enfrentar desafios. Como destaca Visentini (2012, p. 163):

O Vietnã, o Estado pivô da Indochina, oito décadas após sua força política dirigente haver iniciado a resistência ao fascismo, sete após triunfar sobre os japoneses, seis depois de expulsar os franceses e três após ter derrotado os EUA e ter impedido a invasão chinesa, quase duas depois de perder o apoio da potência protetora soviética e vê-la desaparecer, o país enfrenta satisfatoriamente os desafios da globalização e mantém seu regime socialista (de mercado).

É isso que torna a tomada de posição sinuosa, assim como a disputa entre o Vietnã e China extremamente sensitiva, visto que, em um plano, ambos os países comungam do mesmo sistema e ideologia e, em outro, apresentam profundas contradições oriundas de processos históricos e das conflitantes aspirações regionais de ambos os países. Antes mesmo da guerra sino-vietnamita de 1979 eclodir, em 1974 ocorreu a batalha das Ilhas Paracel, uma pequena escaramuça entre as forças chinesas e vietnamitas pelo controle da área, onde o país de Ho Chi Minh sofreu perdas consideráveis. Durante a década de 1980, as tensões fronteiriças estiveram em alta, com acusações de sabotagem vindas principalmente de Hanói. As tensões com a China somente diminuíram na década de 1990, quando o crescimento chinês apareceu como uma oportunidade, em um momento onde a União Soviética se esfacelava e os Estados Unidos mantinham seu embargo contra o país. Desde então, pelo menos no plano institucional, a China e o Vietnã têm mantido um relacionamento estável e amigável, conforme atesta a assinatura de um joint communiqué entre os dois países, por ocasião da visita oficial do secretário-geral do Partido Comunista do Vietnã, Nguyen Phu Trong, à China, entre os dias $12 \mathrm{e}$ 15 de janeiro de 2017.

Por isso, a questão do Mar do Sul é uma disputa quase emocional, onde a resolução do conflito "depende da disponibilidade de cada país em abandonar seus planos e ambições, que estão intimamente ligados à identidade nacional, patrimônio cultural, crescimento econômico e status internacional" 
(CÁCERES, 2014, p. 125). Pois, embora a China se projete como potência mundial, o Vietnã cria cacife para ser o novo tigre asiático.

A questão do Mar do Sul da China tem sido um teste para a dinâmica política e para a integração regional. Nesse sentido, a Declaração Sobre a Conduta das Parte no Mar do Sul da China ${ }^{14}$, de 2002, é ilustrativo da complexidade dos litígios. A declaração pontua que os Estados-membros da ASEAN e o Governo da República Popular da China buscam promover a cooperação, a prosperidade e a confiança mútua; garantir os propósitos e princípios da Carta das Nações Unidas, a Convenção de 1982 das Nações Unidas sobre o Direito do Mar, o Tratado de Amizade e Cooperação no Sudeste Asiático, os Cinco Princípios de Coexistência Pacífica, e outros princípios do direito internacional; permitir a liberdade de navegação e sobrevoo acima do Mar do Sul da China; resolver suas disputas territoriais e jurisdicionais por meios pacíficos, sem recorrer à ameaça ou ao uso da força; promover a proteção do ambiente marinho; combater o crime transnacional, incluindo mas não limitado ao tráfico de drogas ilícitas, a pirataria e assaltos à mão armada no mar, e o tráfico ilegal de armas; dentre outros. Embora não seja um documento capaz de dirimir os conflitos com regras detalhadas, trata-se de um primeiro parâmetro para iniciar uma diplomacia multilateral para resolver o problema.

Um dos efeitos da dinâmica regional de poder e seus conflitos, entre eles os do Mar do Sul da China, tem sido a reaproximação entre Vietnã e EUA. O Vietnã busca uma autonomia em meio ao convívio com dois gigantes: China e EUA. Não quer nem ser um membro submisso de uma eventual reconstituição do sistema sinocêntrico, tampouco se tornar um aliado incondicional do seu maior algoz do processo de independência e unificação do país, os EUA. Com efeito, a diplomacia vietnamita busca uma inserção regional e internacional que lhe confira autonomia e capacidade de negociação, sobretudo no caso dos litígios territoriais.

Conhecedores das relações sino-vietnamitas, os EUA suspenderam o embargo de armas ao Vietnã em maio de $2016^{15}$ e buscam fortalecer as relações bilaterais. Dos 165 U\$ bilhões exportados pelo Vietnã, $18 \%$ foi para os EUA e $11 \%$ para a China - primeiro e segundo destinos. Já as importações, dos 159 U\$ bilhões, $39 \%$ é oriunda da China e 3,9\% dos EUA - primeiro e sétimo fornecedores ${ }^{16}$.

14 Ver detalhes da declaração disponível no site da ASEAN: http://asean.org/?static_post=declaration-on-theconduct-of-parties-in-the-south-china-sea-2

15 El País disponível em: http://brasil.elpais.com/brasil/2016/05/23/internacional/1463986128_113820.html

16 Dados oficiais disponível em: http://atlas.media.mit.edu/en/profile/country/vnm/ 
A conclusão é evidente: a China é o maior parceiro comercial, mas é com os EUA que o Vietnã tem expressivo superávit (os gráficos 1 e 2 abaixo ilustram a evolução econômica e comercial do Vietnã).

Gráfico 1 - Evolução do Produto Interno Bruto do Vietnã - 2005-2015 (U\$ bi).

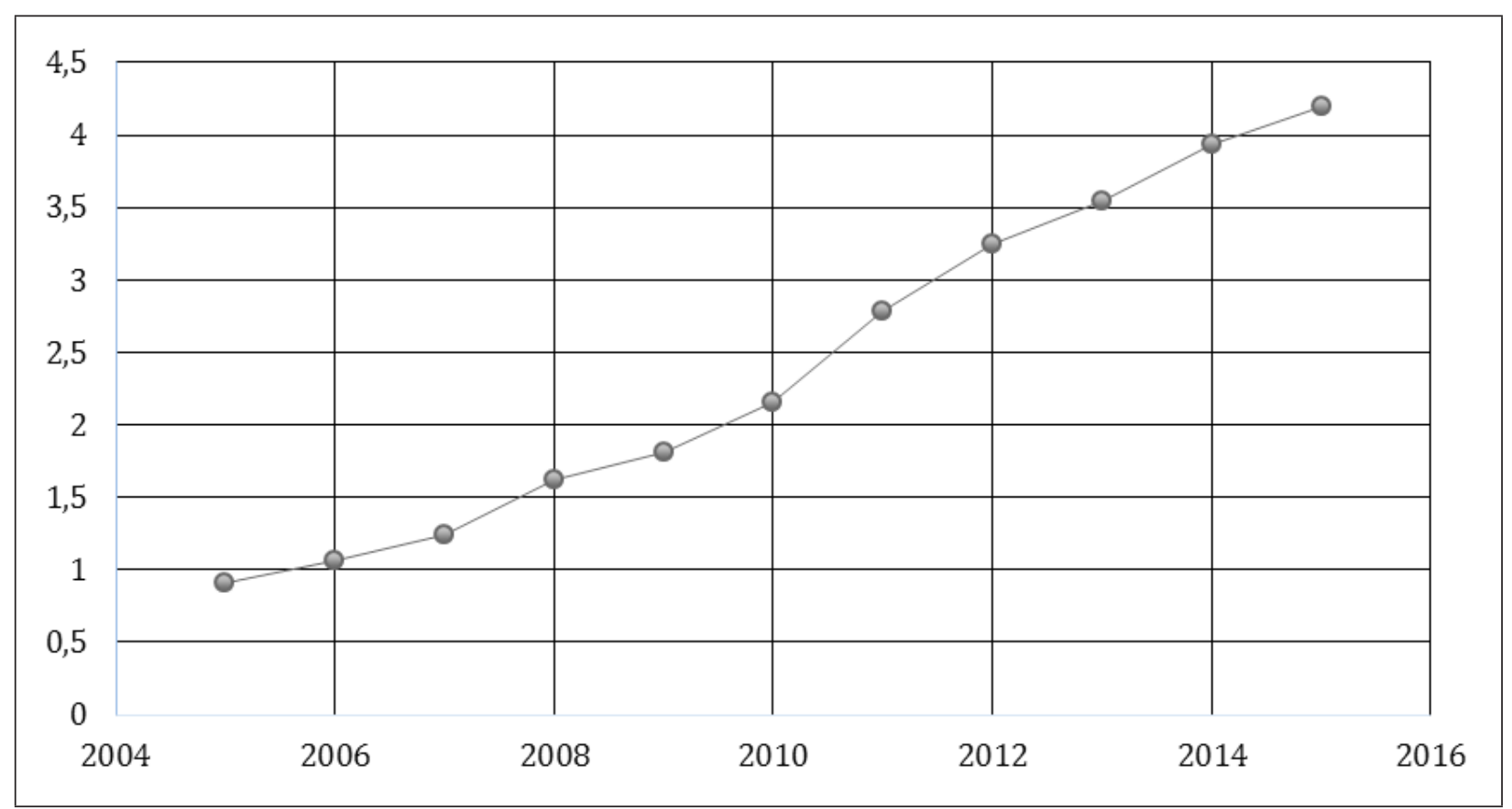

Fonte: IMF, 2017. Dados consultados em 20/07/2017.

Gráfico 2 - Evolução do Fluxo Comercial do Vietnã - 2006-2016 (U\$ mil).

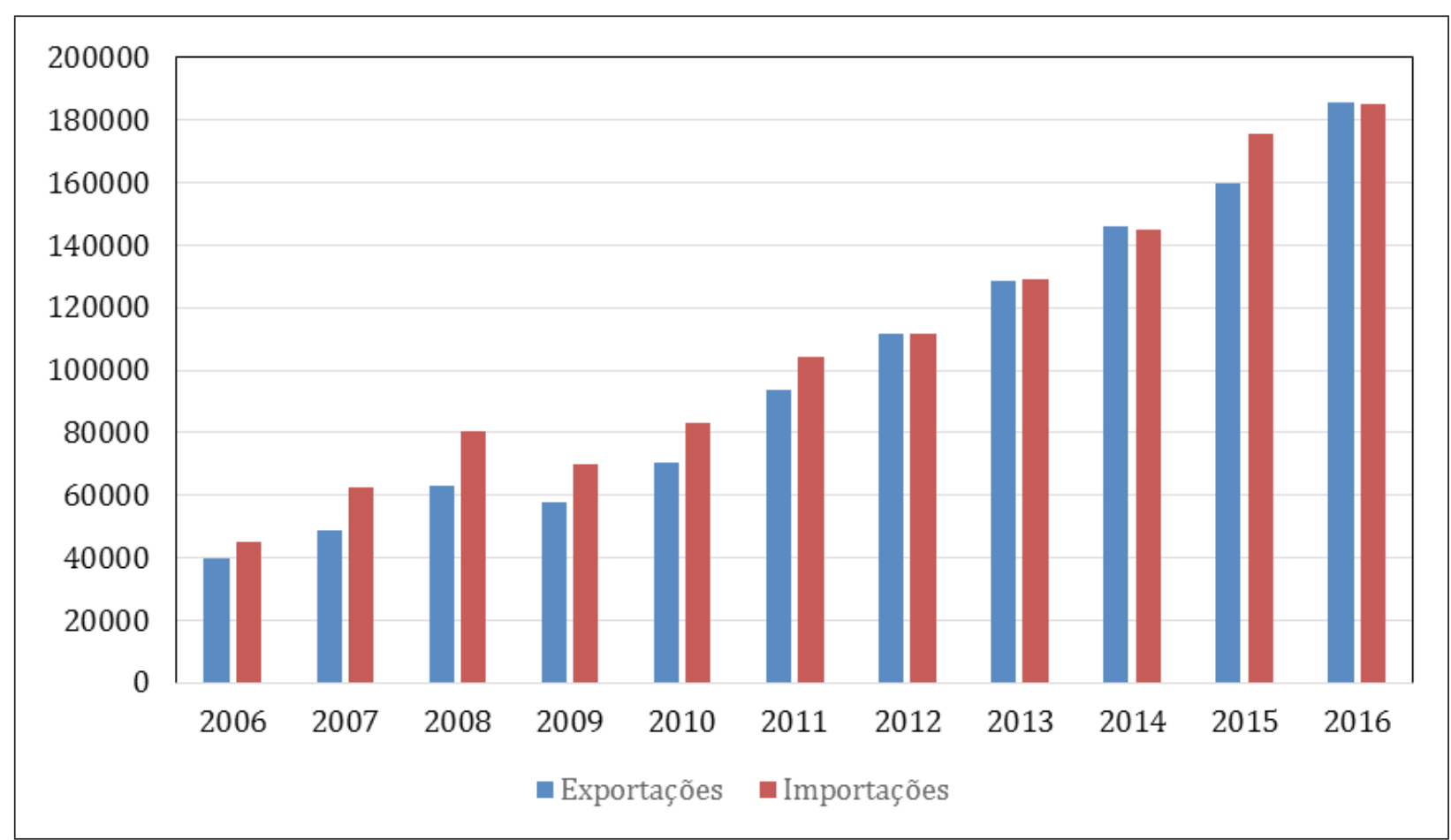

Fonte: IMF, 2017. Dados consultados em 20/07/2017. 
A aproximação do Vietnã com os EUA tem sido evidente e com propósitos bem declarados. De um lado, Harold (2016), do importante think tank estadunidense Rand Corporation, sinaliza claramente que há interesses de contribuir para o rebalanceamento da região, integrando o Vietnã ao Acordo Transpacífico (TransPacific Partnership - TPP) e fortalecendo suas capacidades militares para fazer frente à assertividade chinesa no Mar do Sul da China. Se Obama atuou para suspender ${ }^{17}$, em maio de 2016, o embargo à venda de armas para o Vietnã, decretado em 1975, a eleição de Trump e a retirada dos EUA do TPP colocam novas variáveis na dinâmica regional. Por outro, o Vietnã busca assegurar seus interesses territoriais tendo de lidar não somente com os vizinhos, mas também com uma grande potência (China) e a outra superpotência (EUA) com atuação regional.

Enfim, China e Vietnã estão diante de uma problemática territorial e securitária delicada com potencial de arrastar os países para situações cujo custo superaria em muito os eventuais ganhos. Nesse sentido, têm ocorrido, na esfera diplomática e institucional, tentativas de uma reaproximação amistosa, com promessas de entendimento mútuo e resolução de disputas por formas pacíficas. Em 2011, ambos assinaram um acordo sobre as diretrizes básicas para a resolução de disputas marítimas. O documento declara que "nas negociações sobre questões relacionadas com o mar, os dois lados devem respeitar os acordos e o entendimento comum alcançado por seus líderes de alto nível e aderir aos princípios e no espírito da 'Declaração Sobre a Conduta das Parte no Mar do Sul da China.'”18. Em 2013, durante uma visita oficial ao Vietnã, o premier chinês Li Keqiang disse que "como vizinhos e parceiros, a China e o Vietnã são importantes um para o outro e ambos os países são economicamente complementares com amplo espaço para cooperação prática" ${ }^{19}$. Na época, a mídia vietnamita reportou que os dois lados se comprometeriam a utilizar todos os mecanismos governamentais para resolver disputas territoriais, concordando em estabelecer um grupo de trabalho sobre cooperação marítima dentro dessa perspectiva ${ }^{20}$. Em 2015, o presidente da China, Xi Jinping, em visita ao Vietnã, após encontrar com diversos membros do alto escalão do estado e do Partido Comunista do Vietnã (PCV) na assembleia nacional, declarou que os dois países, ambos aderentes à liderança de partidos

\footnotetext{
17 Ver detalhes no site do Departamento de Defesa dos EUA disponível em: https://www.defense.gov/News/ Article/Article/779762/lifting-embargo-allows-closer-us-vietnam-cooperation-obama-carter-say/

18 Ver http://www.mofa.gov.vn/en/nr040807104143/ns111013131225

19 Ver http://www.china.org.cn/china/2013-06/20/content_29184811.htm

20 Ver http://english.vietnamnet.vn/fms/government/86738/chinese-premier-li-keqiang-visits-vietnam.html
} 
comunistas, firmes no caminho socialista e no aprofundamento compreensivo da reforma, precisam colocar suas relações bilaterais em um patamar de destaque e se esforçar para cimentar uma parceria estratégica ${ }^{21}$. Em janeiro de 2017, em visita do secretário-geral do PCV, Nguyen Phu Trong, a China demonstrou a importância dada à reaproximação entre os dois países comunistas através da assinatura de um novo comunicado conjunto, onde as partes reafirmam os compromissos estabelecidos nos últimos anos²2.

No âmbito social há um profundo descontentamento com a China entre os vietnamitas. As tensões escalaram em 2014, quando a China resolveu instalar uma plataforma de petróleo em área disputada pelos dois países. Houve uma forte reação do povo vietnamita e uma onda de protestos irrompeu, com depredação de instalações físicas de empresas chinesas no Vietnã e ataque aos cidadãos chineses vivendo no país ${ }^{23}$. A imagem da China entre os vietnamitas tem assumido cada vez mais um aspecto negativo. Em 2015, uma pesquisa realizada pelo Pew Research Center em 40 países, com 45.435 respondentes, quando perguntados quais são as maiores ameaças no mundo atualmente, $60 \%$ dos respondentes vietnamitas optaram pelas disputas territoriais com a China. O Vietnã foi o único país do mundo onde essa opção ganhou ${ }^{24}$.

Portanto, as relações sino-vietnamitas sempre foram marcadas pelas vicissitudes geopolíticas e por seu passado, passando ora por fases de intensa cooperação e ora por fases de grande animosidade. Assim, as disputas em torno do Mar do Sul da China também têm influência na política interna e nos padrões de amizade sino-vietnamitas. Em uma carta publicada pelo Journal of Democracy — periódico acadêmico de cunho liberal - , datada de 28 de julho de 2014, 61 membros do Partido Comunista do Vietnã (PCV) - em desacordo com a linha central do Partido - denunciam que:

Por muitos anos, o Partido Comunista do Vietnã liderou a nação na direção errada de construir o socialismo no estilo soviético, baseado no chamado marxismo-leninismo. A política Doi Moi que começou há trinta anos tentou

21 Ver http://news.xinhuanet.com/english/2015-11/06/c_134791569.htm

22 Ver http://hanoitimes.com.vn/news/2017/01/81E0ADEB/full-text-of-vietnam-china-joint-communique/

23 Desde então, diversos incidentes vêm ocorrendo: restaurantes no Vietnã se recusando a atender clientes chineses e um oficial de imigração do Vietnã supostamente escreveu "fuck you" no passaporte de uma chinesa, em cima do mapa onde retrata os territórios disputados como parte da China. Ver informação complementar: http://world.huanqiu.com/exclusive/2016-08/9249497.html

24 Ver: http://www.pewglobal.org/2015/07/14/climate-change-seen-as-top-global-threat/ 
corrigir os erros na política econômica, mas não foi radical o suficiente pois manteve o regime totalitário que restringe a liberdade e a democracia e mantém o nosso povo dividido. ${ }^{25}$

Além da conclamação pelo fim da experiência socialista vietnamita, o documento é dedicado a criticar a postura expansionista chinesa e parte da liderança simpática à China. Há também uma denúncia pela publicação dos detalhes do Acordo de Chengdu, de 1990, onde supostamente a liderança vietnamita fez fortes concessões à RPC. O surgimento desse documento veio no bojo das turbulências enfrentadas devido à instalação de uma plataforma de petróleo chinesa em uma área disputada pelos dois países. A carta revela a existência concreta desses grupos de interesse que terminaram por se manifestar na disputa pelo poder no $12^{\circ}$ Congresso do Partido Comunista do Vietnã, realizado em 2016. De um lado, o primeiro-ministro Nguyen Tan Dung, considerado como grande proponente da economia de mercado dentro do PCV, ganhou notoriedade durante a crise da plataforma de petróleo chinesa em 2014 ao aumentar o tom contra a China ${ }^{26}$. É um dos grandes defensores da aproximação do Vietnã com os Estados Unidos. Do outro lado, o secretário-geral do PCV Nguyen Phu Trong, educado na União Soviética, é considerado um dos grandes ideólogos do partido, busca realinhar a organização com seus princípios fundadores e enxerga na China um aliado ideológico e estratégico. (LE, 2017, p. 78-83).

A contenda deve ser interpretada para além da disputa pelo cargo de secretáriogeral vencida por Nguyen Phu Trong, reeleito para o cargo após uma concessão do partido em estender seus direitos políticos para além da idade máxima para a aposentadoria compulsória. A diferença entre os dois candidatos está no que Tuong Vu, cientista político na Universidade de Oregon, em entrevista ao New York Times, ressaltou: "todas as facções concordam com a necessidade de investimentos e comércio, mas a facção de Trong resistirá a quaisquer concessões, enquanto a facção de Dung tentaria assinalar reformas para manter o dinheiro entrando" 27. Para além dessas diferenças, a disputa política influi na inserção internacional do Vietnã, mais ou menos alinhada com China e/ou Estados Unidos e na direção dos conflitos no Mar do Sul.

\footnotetext{
25 Ver: http://journalofdemocracy.org/sites/default/files/custom_search/Letter \%20from \%2061 \% 20Vietnamese \% 20 Party \% 20members.pdf

26 Ver: https://www.nytimes.com/2014/05/12/world/asia/vietnam.html

27 Ver: https://www.nytimes.com/2016/01/28/world/asia/vietnam-communist-party-nguyen-phu-trong.html?_r=0
} 
Em suma, no curto prazo pelo menos, a política externa do Vietnã continua sendo marcada pela independência, autossuficiência e busca por diversificação e multilateralização das relações internacionais. A posição geográfica e a história do Vietnã empurram o país nessa direção. No entanto, a busca pela reaproximação com os EUA, para contrabalancear a assertividade da China, não esvazia o conteúdo nacional e seus compromissos ideológicos. A pareceria com a China tampouco tem como objetivo uma aliança cega baseada em concessões ilimitadas. O desafio está posto.

\section{Para além das disputas sino-vietnamitas no Mar do Sul}

É possível que os EUA tenham influenciado a demanda filipina junto ao Tribunal de Haia para fomentar o litígio e a consequente construção de alianças antichinesas na região. Não se deve esquecer os laços que os unem, dado que os EUA concederam a independência das Filipinas condicionada ao estabelecimento de suas bases militares (LOSURDO, 2016, p. 247). Mas, de acordo com Viktor Sumsky ${ }^{28}$, diretor do Centro da ASEAN na Universidade de Relações Internacionais de Moscou, o encaminhamento ao tribunal tende a produzir um resultado contraproducente e potencializar o conflito, uma vez que o direito internacional existe para resolver pacificamente as situações de conflito, sobretudo porque a iniciação do processo de arbitragem exige a concordância de ambos os lados.

Os EUA, em conjunto com seus aliados, anteciparam-se em criticar a China pela decisão de não respeitar a decisão da corte. Cabe destacar que os próprios Estados Unidos, em 1986, ignoraram uma arbitragem do Tribunal de Haia, que declarou suas atividades na Nicarágua ilegais. Além disso, não consta que os membros permanentes do Conselho de Segurança da ONU sejam notórios aplicadores das normas internacionais que eles julguem que possam infringir suas soberanias e interesses nacionais. A decisão unilateral dos EUA de invadirem o Iraque e a anexação da Crimeia pela Rússia são dois exemplos dessa tendência. Não obstante a postura estadunidense, fica a dúvida acerca do comportamento que a China irá adotar para dirimir esse conflito sem replicar as práticas das potências tradicionais — inclusive em razão da importância logística do Mar do Sul (Figura 1).

28 Em declaração dada à Sputnik Brasil, disponível em: http://br.sputniknews.com/mundo/20160708/5511304/ haia-china-filipinas.html 
Figura 1 - As redes de transporte terrestres e marítimas ${ }^{29}$.

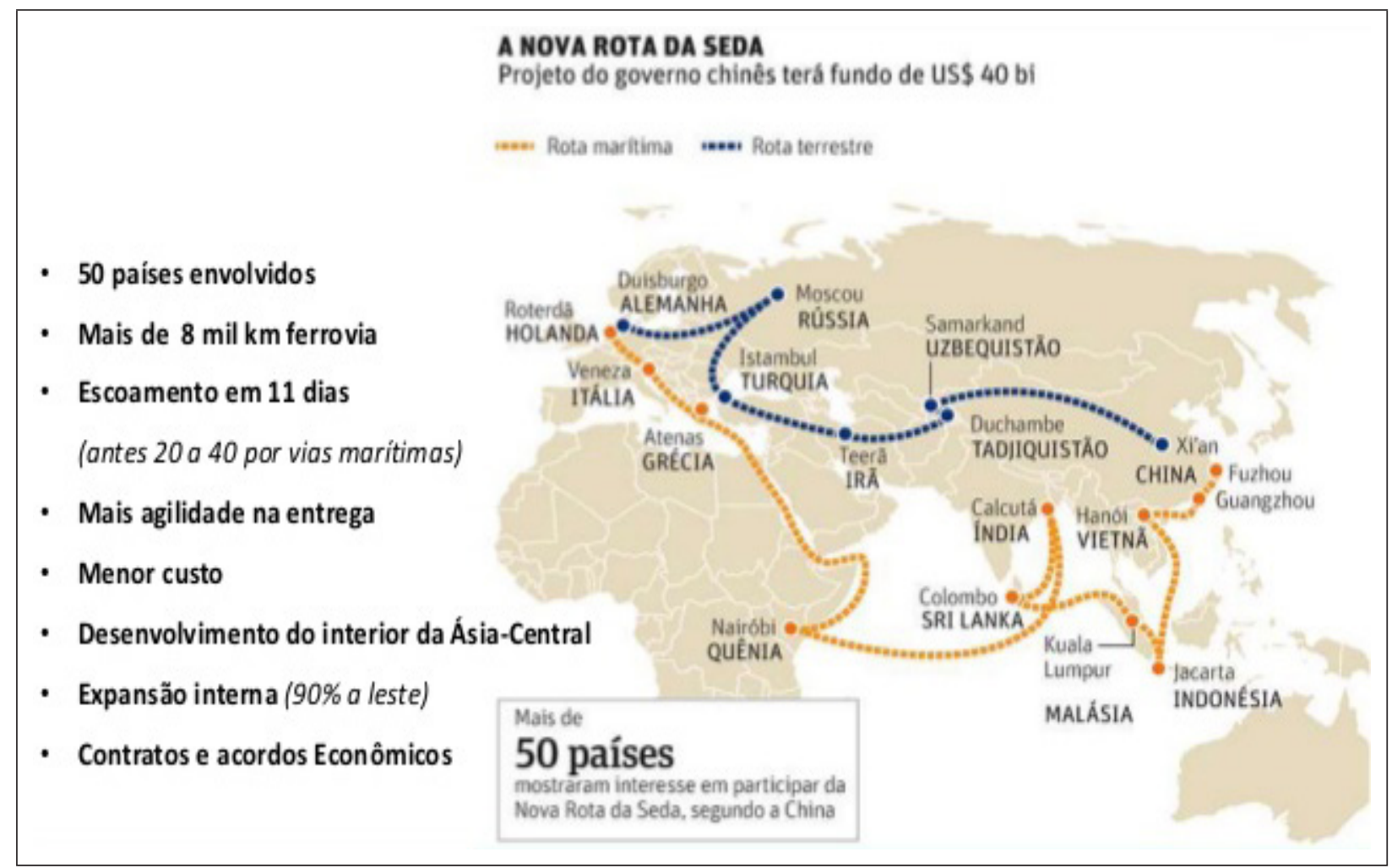

Fonte: FSP. Disponível em: http://www1.folha.uol.com.br/mercado/2015/10/1695869-politica-externa-chinesa-buscacriar-uma-nova-estrada-da-seda.shtml.

Embora haja legítimas disputas territoriais por essa região, é importante reconhecer que as raízes são mais profundas. A começar pelo fato de que os EUA não são signatários da Convenção das Nações Unidas sobre o Direito do Mar documento no âmbito do direito internacional que dispõe sobre os conceitos relacionados ao mar territorial - e tampouco fazem parte da região. Ou, como destaca Losurdo (2016, p. 238), os EUA são reincidentes em desconsiderar os organismos internacionais, como foi o caso da condenação em 1986 do Tribunal de Haia pelas agressões contra a Nicarágua sandinista ou mesmo a rejeição à Corte Penal Internacional.

Nesse sentido, para os interesses estratégicos dos EUA, as disputas no Mar do Sul da China se prestam a muitos objetivos regionais. Primeiro, fortalecer a narrativa da "ameaça chinesa", a partir de seu militarismo e expansionismo. Segundo, ampliar sua presença militar na região como forma de resguardar seus parceiros. Terceiro, fomentar padrões de inimizade para fragilizar a liderança da China na região. Quarto, gerar dissensos para fragilizar as iniciativas de integração

29 Há outras versões desse mapa Disponível em: Maps of China - http://english.igsnrr.cas.cn/eocg/moc/. O IGSNRR é o Instituto de Geografia e Ciências Naturais diretamente ligado à Academia Chinesa de Ciências. 
regionais conduzidas pelos chineses, tanto relacionadas à ASEAN quanto à Rota da Seda Marítima. Quinto, tentar engolfar a China num conflito regional que seria o "seu Vietnã". Cabe destacar que os EUA usam o controle sobre o Estreito de Malaca, o cerco militar e a chantagem nuclear como uma ameaça permanente à China (KAPLAN, 2015).

A ascensão da China, até o presente momento, foi um processo pacífico e relativamente suave, onde a ordem internacional - não sem atritos - abriu espaço para acomodar a nova potência econômica. O país asiático foi sagaz ao buscar oportunidades em regiões esquecidas pelo eixo euro-estadunidense. No entanto, à medida que a influência e o poderio chinês crescem, também crescem suas responsabilidades diplomáticas internacionais. A estratégia adotada de não intervenção e neutralidade, que garantiu poucos desgastes para a China, já não comporta mais os desafios e barreiras do quadro atual enfrentado pela crescente assertividade do país asiático.

É evidente que os EUA vão explorar os conflitos na Ásia-Pacífico para criar entraves à liderança chinesa. Kissinger foi explicito, por exemplo, em indicar que o Japão deve redefinir seu papel na ordem mundial e se tornar um "país normal" (KISSINGER, 2011, p. 193). Para os EUA, não interessa apenas que o Japão seja um aliado militarmente capaz e assertivo, mas também justificar a forte presença dos EUA na península coreana (face à Coreia do Norte) e no Mar do Sul. Não é por acaso que a presença militar dos EUA, com exercícios e manobras, tem ocorrido com regularidade. Por exemplo, em junho de 2016, os dois maiores porta-aviões estadunidenses, os USS John C. Stennis e USS Ronald Reagan, participaram de exercícios militares no Mar das Filipinas, com mais de 12 mil marinheiros, 140 aeronaves e 6 navios de guerra ${ }^{30}$. A desproporção de forças combinado ao evidente e histórico "poder de polícia internacional" autoconferido aos EUA são razões suficientes para as preocupações chinesas e para o risco de uma escalada militar.

O jornalista e especialista na questão, Bill Hayton, assinalou corretamente que dois imperativos estratégicos e diversos interesses regionais colidem no Mar do Sul da China. A disputa é perigosa pois cristaliza, de certa forma, a imagem que as duas nações conferem a si próprias. De um lado, está a China que, através do Partido Comunista da China, busca o rejuvenescimento da nação chinesa e a recuperação dos territórios e dignidade perdidos no chamado Século das Humilhações, de outro, estão os Estados Unidos e seu destino manifesto de líder

30 Ver informações na Sputnik Brasil, disponível em: http://br.sputniknews.com/mundo/20160622/5228728/ rivalidade-pequim-washington.html 
global, protetor do "mundo livre" e guardião da ordem internacional. Hayton sustenta que o Mar do Sul da China é o primeiro lugar onde as normas e regras desse sistema internacional estão sendo desafiadas pela China, pois se os EUA perdem o controle sobre as navegações pela região, perderão sua predominância global e se tornarão apenas mais uma potência. Caso isso ocorra, o "choque seria profundo e as consequências para a identidade, prosperidade e segurança estadunidenses, devastadoras" (HAYTON, 2014, p. 208).

Em suma, essas demonstrações de força revelam que os EUA estão cada vez menos dispostos a assistir à ascensão chinesa. Com efeito, a questão do Mar do Sul da China é mais uma das formas de tentar contê-la, tal como foi feito com a URSS durante a Guerra Fria. A isso se somam os intentos estadunidenses para desagregar a China através de movimentos separatistas no Tibete e no Xingjian (BANDEIRA, 2013, p. 119). Há inclusive de se considerar o paralelo existente entre o conflito da Ucrânia e os litígios no Mar do Sul. Em ambos os casos, tem se tentado engolfar as potências desafiantes - China e Rússia - em conflitos regionais. A partir disso, é possível "vilanizar" os países em questão e criar enormes desafios às suas iniciativas internacionais. É inegável, por fim, que a questão do Mar do Sul certamente será um marco divisor na atuação internacional da China.

\section{Conclusões}

O litígio no Mar do Sul da China é, sem dúvida, um dos temas mais importantes das relações internacionais contemporâneas. Trata-se de uma questão complexa pois envolve i) diversos contendores regionais e ainda o protagonismo da superpotência (EUA) extrarregional; ii) a superposição de dinâmicas de integração com o recrudescimento da competição; e iii) entrelaçamento de padrões de relacionamento histórico (sinocêntrico) com a sobreposição dos conceitos centrais ao moderno sistema de governança mundial (HADDICK, 2014).

A política estadunidense é de contenção da China, se possível eliminando as peças (aliados) do seu oponente, quiçá numa vitória total. Ao invés do xadrez, a China prefere uma política de campanha prolongada, movendo-se pelos espaços "vazios", mitigando o potencial estratégico do oponente de maneira flexível, onde os elementos políticos e psicológicos são tão importantes como os militares (Tzu). O conflito no Mar do Sul tem claramente elementos dessa cosmologia, sem deixar de ter agregado novas concepções e meios. 
A China, como potência da região, tem percorrido o caminho sinuoso de, a um só tempo, preservar sua segurança e liderar os processos de integração regionais, mas sem replicar um padrão expansionista que legitime a estratégia estadunidense. A China busca a recriação do sistema sinocêntrico a partir de iniciativas para liderar a integração regional (ASEAN + 6 e Organização para a Cooperação de Xangai), amarrado na Nova Rota da Seda Continental e Marítima (One Belt, One Road) e no Banco Asiático de Investimento em Infraestrutura. Não resta dúvidas que a Iniciativa OBOR provoca novas demandas e desafios geopolíticos e geoeconômicos para a China, ao passo que atesta a necessidade de compatibilizar as relações “win-win” com a atuação assertiva de sua diplomacia (PAUTASSO, UNGARETTI, 2017). Se houver sentido na hipótese de que a Nova Rota da Seda é um projeto chinês de globalização, esse só será viável com a viabilização da integração regional e, com efeito, dependeria de um padrão de relacionamento estável na região e o equacionamento - ou pelo menos o gerenciamento - dos litígios no Mar do Sul da China.

Mas o Vietnã tem uma estratégia de hedging baseada no reforço e diversificação das suas relações externas diante da assertividade regional da China (TRAN; VIEIRA; FERREIRA-PEREIRA, 2013). Aliás, os países da região buscam a um só tempo fazer parte dessa janela de oportunidade ligada à Iniciativa OBOR e preservar a autonomia diante do gigante asiático. Para tanto, mantêm equilíbrio delicado entre China e EUA, numa nítida política de barganha. Resta saber se os choques de objetivos, de temporalidades e de cosmologias poderão ser administrados.

\section{Referências}

BANDEIRA, Luiz. Segunda Guerra Fria. Rio de Janeiro: Civilização Brasileira, 2013. BUZAN, Barry; HANSEN, Lene. A evolução dos Estudos de Segurança Internacional. São Paulo: UNESP, 2012.

BUSZYNSKI, Leszek. The South China Sea: Oil, Maritime Claims, and U.S.-China Strategic Rivalry. The Washington Quarterly. Vol. 35, n 2, 2012, pp. 139-156. Disponível em: http://www.tandfonline.com/doi/abs/10.1080/0163660X.2012.666495.

CÁCERES, Sigfrido Burgos. China's Strategic Interests in the South China Sea: Power and resources. New York: Routledge, 2014.

DAI, Bingguo. Speech by Dai Bingguo at China-US Dialogue on South China Sea Between Chinese and US Think Tanks. Ministry of Foreign Affairs of the People's Republic of China. 07 05, 2016. http://www.fmprc.gov.cn/mfa_eng/zxxx_662805/t1377747.shtml (accessed 07 15, 2016). 
DENG, Xiaoping. Selected Works of Deng Xiaoping Volume III. Vol. III. III vols. Beijing: Foreign Language Press, 1994.

FRAVEL, M. Taylor. China’s Strategy in the South China Sea. Contemporary Southeast Asia, vol. 33, no. 3, 2011,p. 292-319. Disponível em: https://taylorfravel.com/documents/ research/fravel.2011.CSA.china.strategy.scs.pdf.

GABINETE DE IMPRENSA DO CONSELHO DE ESTADO DA CHINA. A China persiste em resolver através de negociações as disputas com as Filipinas no Mar do Sul da China. Rádio Internacional da China. 07 13, 2016. http://portuguese.cri.cn/1721/ 2016/07/13/1s218533.htm (accessed 07 18, 2016).

GILL, Bates. Rising Star: China's New Security Diplomacy. Wahington: Brooking Instituto Press, 2007.

GLOBAL TIMES. China's reaction to arbitration depends on provocation. 07 12, 2016. http://www.globaltimes.cn/content/993655.shtml (accessed 07 15, 2016).

GUAN, Ang Cheng. Vietnam-China Relations since the End of the Cold War. Asian Survey (University of California Press) Vol. 38, no. 12, 1998, p. 1122-1141.

Haddick, Robert. Fire on the Water: China, America, and the Future of the Pacific. New York: Naval Institute Press, 2014.

HAYTON, Bill. The South China Sea: The Struggle for Power in Asia. New Haven: Yale University Press, 2014.

HAROLD, Scott. Why Obama Lifted de Arms Sales Ban on Vietnam? 2016. https://www. rand.org/blog/2016/05/why-has-obama-lifted-the-arms-sales-ban-on-vietnam.html. Acesso 10/03/2017.

IMF. World Economic Outlook. 2017. Disponível em: http://www.imf.org/en/publications/weo. KANG, David. Hierarchy and stability in Asian international relations. In: IKENBERRY, John; MASTANDUNO, Michael. International Relations Theory and the Asia-Pacific. New York: Columbia, 2003, pp. 163-189.

Kaplan, Robert D. Asia's Cauldron: The South China Sea and the End of a Stable Pacific. New York: Random House Trade Paperbacks, 2015.

Kissinger, Henry. Sobre a China. Rio de Janeiro: Objetiva, 2011.

LE, Hong Riep. Living Next to the Giant: The Political Economy of Vietnam's Relations with China Under Doi Moi. Singapore: ISEAS Publishing, 2017.

Li, Jingzhi, and Ping Pu. The Choice of China: Peaceful Development and Construction of a Harmonious World. Beijing: Renmin University Press, 2012.

LI, Xue. 薛力: 南海问题上中美都应有所反思. 共识网. 06 29, 2016. http://www.21ccom. net/html/2016/zlwj_0629/5358.html (accessed 07 19, 2016).

LIU, Zhenmin. China Remains Committed to Peaceful Settlement of Disputes in the South China Sea through Negotiations and Consultations. Ministry of Foreign Affairs of the People's Republic of China. 03 25, 2016. http://www.fmprc.gov.cn/mfa_eng/wjbxw/ t1350776.shtml (accessed 07 18, 2016).

LOSURDO, Domenico. A esquerda Ausente. São Paulo: Anita Garibaldi, 2016. 
MINISTÉRIO DAS RELAÇÕES EXTERIORES DA REPÚBLICA POPULAR DA CHINA. Declaração do Ministério das Relações Exteriores da China sobre o veredicto do Tribunal Arbitral na Arbitragem do Mar do Sul da China. 07 12, 2016. http://portuguese.cri. cn/1721/2016/07/12/1s218493.htm (accessed 07 18, 2016).

MINISTRY OF FOREIGN AFFAIRS OF THE PEOPLE'S REPUBLIC OF CHINA. China's Position Paper on the New Security Concept (July 31, 2002). Ministry of Foreign Affairs of the People's Republic of China. 08 06, 2002. http://www.fmprc.gov.cn/mfa_eng/ wjb_663304/zzjg_663340/gjs_665170/gjzzyhy_665174/2612_665212/2614_665216/ t15319.shtml (accessed 07 17, 2016).

PAUTASSO, Diego; UNGARETTI, Renato. A Nova Rota da Seda e a recriação do sistema sinocêntrico. Estudos Internacionais. Vol. 4, n ${ }^{\circ}$ 3, 2016, p. 25-44. Disponível em: http://periodicos.pucminas.br/index.php/estudosinternacionais/article/view/13874 PEREIRA, Analúcia D.; MEDEIROS, Klei. O Prelúdio da Cooperação Sul-Sul: da Conferência de Bandung à Conferência de Buenos Aires (1955-1978). I Seminário Internacional de Ciência Política Universidade Federal do Rio Grande do Sul, Porto Alegre, Set. 2015. QIANG, Zhai. China and the Vietnam Wars, 1950-1975. The University of North Carolina Press, Chapel Hil, 2005.

SHARROCK, Peter D.; LIEN, Vu Hong. Descending Dragon, Rising Tiger: A History of Vietnam. London: Reaktion Books, 2014.

SHICUN, Wu, ed. What one needs to know about the South Sea. Beijing: Current Affairs Press, 2015.

TALMON, Stefan; BING, Bingjia. The South China Sea Arbitration: A Chinese Perspective. Oxford: Hart Publishing, 2014.

TRAN, Phuc Thi; VIEIRA, Alena; FERREIRA-PEREIRA, Laura, Vietnam's strategic hedging vis-à-vis China: the roles of the European Union and Russia. Revista Brasileira de Política Internacional. Vol. 56, $\mathrm{n}^{\circ}$. 1, 2013, p. 163-182. Disponível em: http://www. scielo.br/scielo.php?script = sci_arttext\&pid = S0034-73292013000100009

VISENTINI, Paulo. As Relações Diplomáticas da Ásia. Belo Horizonte: Fino Traço, 2012. Zhang, Haiwen, ed. The South China See and its Island. Beijing: China Intercontinental Press, 2014.

ZHENG, Bijian. China's Peaceful Rise: Speeches of Zheng Bijian 1997. Washington: Brookings Institution Press, 2005. 


\title{
O papel do Brasil na evolução das Operações de Paz ${ }^{1}$ Brazilian contribution in the peace operations' evolution
}

\author{
DOI: $10.21530 /$ ci.v12n3.2017.667
}

Anselmo de Oliveira Rodrigues ${ }^{2}$

Eduardo Xavier Ferreira Glaser Migon ${ }^{3}$

\section{Resumo}

O presente artigo tem como objetivo revisar a evolução conceitual das operações de paz sob a égide da Organização das Nações Unidas (ONU), destacando a contribuição brasileira no contexto dessas. Para isso, inicialmente, é apresentada a preocupação da sociedade com as questões associadas à paz e à guerra, apresentando a criação da ONU nesse cenário. Ainda na primeira seção, é definida a taxonomia do artigo e seus principais aspectos. Nesse enfoque, o presente trabalho tomou, como base de estudo, as operações de paz ocorridas no período compreendido entre o término da $2^{\text {a }}$ Guerra Mundial e o ano de 2016. Nas quatro seções seguintes, são analisadas as gerações de operações de paz, destacando suas principais características e o papel do Brasil nessa dinâmica, ressaltando os aspectos qualitativos e quantitativos da contribuição brasileira. Na última seção, é realizada uma análise da evolução das missões de paz e a contribuição brasileira nesse processo.

Palavras-chave: Brasil, ONU, missões de paz, segurança internacional.

\section{Abstract}

This article aims to review the conceptual evolution of peace operations under the aegis of the United Nations (UN), highlighting the Brazilian contribution in this context. To this, initially, is presented the society's concern with issues related to peace and war, presenting the creation of the UN in this scenario. Still in the first section, the taxonomy of the article is defined and its main aspects. In this approach, the present study took as a base of study

1 A pesquisa associada ao presente artigo foi conduzida no âmbito do projeto A importância da África para a Segurança e Defesa do Brasil, desenvolvido sob fomento do Programa Álvaro Alberto de Indução à Pesquisa em Segurança Internacional e Defesa Nacional (Pró-Pandiá), iniciativa conjunta CAPES — Ministério da Defesa. Após o encerramento desse, foi finalizada no âmbito do projeto A importância da África para a Segurança \& Defesa do Brasil: passado, presente e futuro das Operações de Paz no continente africano.

2 Programa de Pós-Graduação em Ciências Militares do Instituto Meira Mattos, da Escola de Comando e Estado-Maior do Exército (ECEME), Rio de Janeiro/RJ, Brasil. E-mail: capanselmo98@ig.com.br

3 Programa de Pós-Graduação em Ciências Militares do Instituto Meira Mattos, da Escola de Comando e Estado-Maior do Exército (ECEME), Rio de Janeiro/RJ, Brasil. E-mail: eduardomigon@gmail.com

Artigo submetido em 18/04/2017 e aprovado em 11/12/2017. 
the peace operations that occurred between the end of the Second World War and the year 2016. In the following four sections, the generations of peace operations are analyzed, highlighting their main characteristics and the role of Brazil in this dynamic, highlighting the qualitative and quantitative aspects of the Brazilian contribution. In the last section, an analysis is made of the evolution of mission operations and the Brazilian contribution in this process.

Keywords: Brazil, UN, peace missions, international security.

\section{Introdução}

As questões associadas à dicotomia entre a guerra e a paz vêm sendo estudadas por diferentes áreas do conhecimento, a exemplo da filosofia, ciência política, direito, ciências militares e relações internacionais. Também por diferentes campos de estudos, a exemplo dos estudos de defesa, estudos estratégicos e estudos de área. Desde Hugo Grotius até Norberto Bobbio (MIGON, 2012), passando por Clausewitz (HOWARD, 2002), alargado rol de pensadores e perspectivas tem sido trazido a lume.

Com igual sentido, percebe-se, desde o início do século XX, a contínua preocupação internacional em estruturar e manter uma organização supranacional capaz de cooperar com a busca e fortalecimento da paz internacional. Sob tal razão foi constituída a Liga das Nações (1919), organização internacional no âmbito da qual o Brasil prontamente se fez presente (PINHEIRO DA CUNHA; MIGON; VAZ, 2014) e cujas ações podem ser conhecidas tanto a partir da obra clássica de Howard-Ellis (1928) quanto na análise contemporânea de Pedersen (2015). Sob os mesmos ideais, e poucos anos depois, a Liga das Nações foi substituída pela Organização das Nações Unidas (ONU), organismo internacional que contemporaneamente se dedica, dentre outras, às questões da segurança internacional.

Assim, em 16 de junho de 1945, firmou-se a Carta das Nações Unidas na Conferência de São Francisco. Esse documento conferiu ao Conselho de Segurança das Nações Unidas (CSNU) a responsabilidade pela preservação da paz e da segurança internacionais. Nesse escopo, mesmo não tendo sido prevista na Carta de São Francisco, as operações de paz (OPs) foram idealizadas pela ONU e se tornaram o principal instrumento da organização para a manutenção da paz internacional (REZENDE; AZEVEDO, 2011). 
As missões onusianas tiveram seu início com o término da $2^{\text {a }}$ Guerra Mundial (GM), particularmente no ano de 1948, e se estendem até os dias atuais. Nesse período, a doutrina dessas operações evoluiu de acordo com o ambiente internacional existente em cada época, vindo a sofrer uma série de transformações desde a forma como foi concebida em 1948 até a maneira como está sendo utilizada nos dias atuais (BELLAMY, 2004).

Um dos principais fatores que motivaram a transformação das missões de paz foi a preocupação, crescente, com a proteção das pessoas. Isso fez com que as OPs evoluíssem para uma melhor gestão dos conflitos, e não mais para a simples resolução dos mesmos. $\mathrm{O}$ aspecto humanitário das missões de paz tornou-se central, balizando a concepção de emprego dos profissionais da ONU (KENKEL, 2013).

Em termos metodológicos, e considerando que essa possivelmente seja a parte mais importante de todo o estudo e, portanto, precisa ser apresentada de maneira clara e específica (CRESWELL, 2010), destaca-se o objetivo dessa comunicação de pesquisa, que é o de revisar a evolução conceitual das OPs, destacando a contribuição brasileira no contexto dessas. O Brasil foi escolhido como o caso a ser estudado pela preocupação que o país tem demonstrado, nos últimos anos, em participar efetivamente da agenda de segurança internacional, e a colaboração nas OPs foi uma maneira que o país encontrou para se inserir nessa agenda (AGUILAR, 2015).

Para isso, adotou-se como recorte temporal as missões ocorridas entre o final da $2^{\text {a }}$ GM e o ano de 2016, inclusive. E, como recorte institucional, foram investigadas exclusivamente as missões conduzidas pela ONU, excluindo-se as operaç̃oes sob a égide de outros organismos internacionais.

Assim, a análise foi realizada verificando todas as contribuições em pessoal realizadas pelo Brasil em OPs, abrangendo as participações com grandes efetivos e as participações realizadas sob a forma de Token Troop Contributions. Coleman entende que as Token Troop Contributions podem ser feitas sob três formas: 1) contribuições com pessoal para cargos seniores nas OPs, 2) contribuições com pessoal para cargos de observadores militares nas OPs e 3) contribuições com pessoal em tropas formadas por contingentes de diversos países (COLEMAN, 2013).

A fim de propor uma sistematização e enquadramento conceitual ao estudo das missões de paz, este artigo está estruturado da seguinte forma: inicialmente é apresentada a preocupação da sociedade com as questões associadas à paz e à guerra, destacando a criação da ONU. Na primeira seção ainda são definidos o objetivo e os limites de investigação desse estudo. Nas quatro seções seguintes, 
são analisadas as gerações de OPs, destacando suas principais características e o papel do Brasil nessa dinâmica, ressaltando os aspectos qualitativos e quantitativos da contribuição brasileira. Na última seção, é realizada uma análise da evolução das missões de paz e o papel do país nesse processo.

\section{A $1^{\text {a }}$ Geração das operações de paz}

Logo após a $2^{\text {a }} \mathrm{GM}$, o mundo sentiu a necessidade de criar uma entidade internacional que fosse capaz de estabelecer parâmetros aceitáveis para que a paz pudesse prevalecer entre as nações, ou pelo menos para que os conflitos não atingissem níveis alarmantes (PENNA FILHO, 2004).

Porém, a realidade mundial nessa época freou o ímpeto da ONU, com a Guerra Fria dividindo o mundo em dois blocos antagônicos e travando o processo decisório do Conselho de Segurança das Nações Unidas (CSNU), pois o emprego de força estava condicionado à unanimidade dos cinco membros permanentes: Estados Unidos da América (EUA), ex-União das Repúblicas Socialistas Soviéticas (URSS), China, França e Grã-Bretanha (BOUTROS-GHALI, 1993). Diante dessa realidade, a ONU não conseguiu colocar em prática o que havia idealizado inicialmente para as OPs.

Foi nesse ambiente que surgiu a $1^{\text {a }}$ Geração, em 1948, dividida entre a manutenção de paz mundial e a realidade imposta pelo confronto bipolar no seio da ONU. Assim, o período que engloba o término da $2^{\text {a }} \mathrm{GM}$ e o final da Guerra Fria compreende o surgimento de todas as OPs que atuaram sob o escopo da $1^{\text {a }}$ Geração das operações de paz e que ainda estão em curso atualmente.

O traço marcante na concepção de emprego das OPs estava baseado em não empregar a força nas operações, estando apenas autorizado o uso da força em legítima defesa das tropas da ONU (BRAGA, 2012). Miall alimenta a discussão ao acrescentar que as missões onusianas ocorridas nessa época exerciam a função de monitorar as fronteiras, estabelecendo zonas tampão, depois de ter conseguido o acordo de cessar fogo entre os beligerantes (MIALL, 1999).

Já Kenkel assinala que a principal característica das missões de paz dessa geração estava na implantação de uma força de interposição na linha de frente entre os contendores, reduzindo o contato entre opositores e diminuindo a probabilidade de escalada da crise (KENKEL, 2013). 
Em vista disso, depreende-se que as OPs possuíam três atores basicamente: dois Beligerantes e uma Força de Interposição. Ainda que enquadrados num cenário belicoso, um traço importante se baseava na convergência dos três atores para um mesmo objetivo, que era pôr fim ao conflito por meio de uma resolução política (BELLAMY; WILLIAMS, 2009).

A ONU reforça o conceito anterior ao assinalar que essas missões possuíam objetivo limitado a, tão somente, estabilizar a situação em campo para que houvesse um espaço político no qual fosse possível resolver o conflito por meios pacíficos (DPKO/DFS, 2008). Em vista disso, Cepik e Kuele destacam que as três principais características das missões de paz dessa época são as seguintes: 1) consenso entre as partes envolvidas no conflito, 2) imparcialidade e 3) não uso da força (CEPIK; KUELE, 2015). O gráfico 1 apresenta as missões de $1^{\text {a }}$ Geração:

\section{Gráfico 1: OPs de $1^{\text {a }}$ Geração}

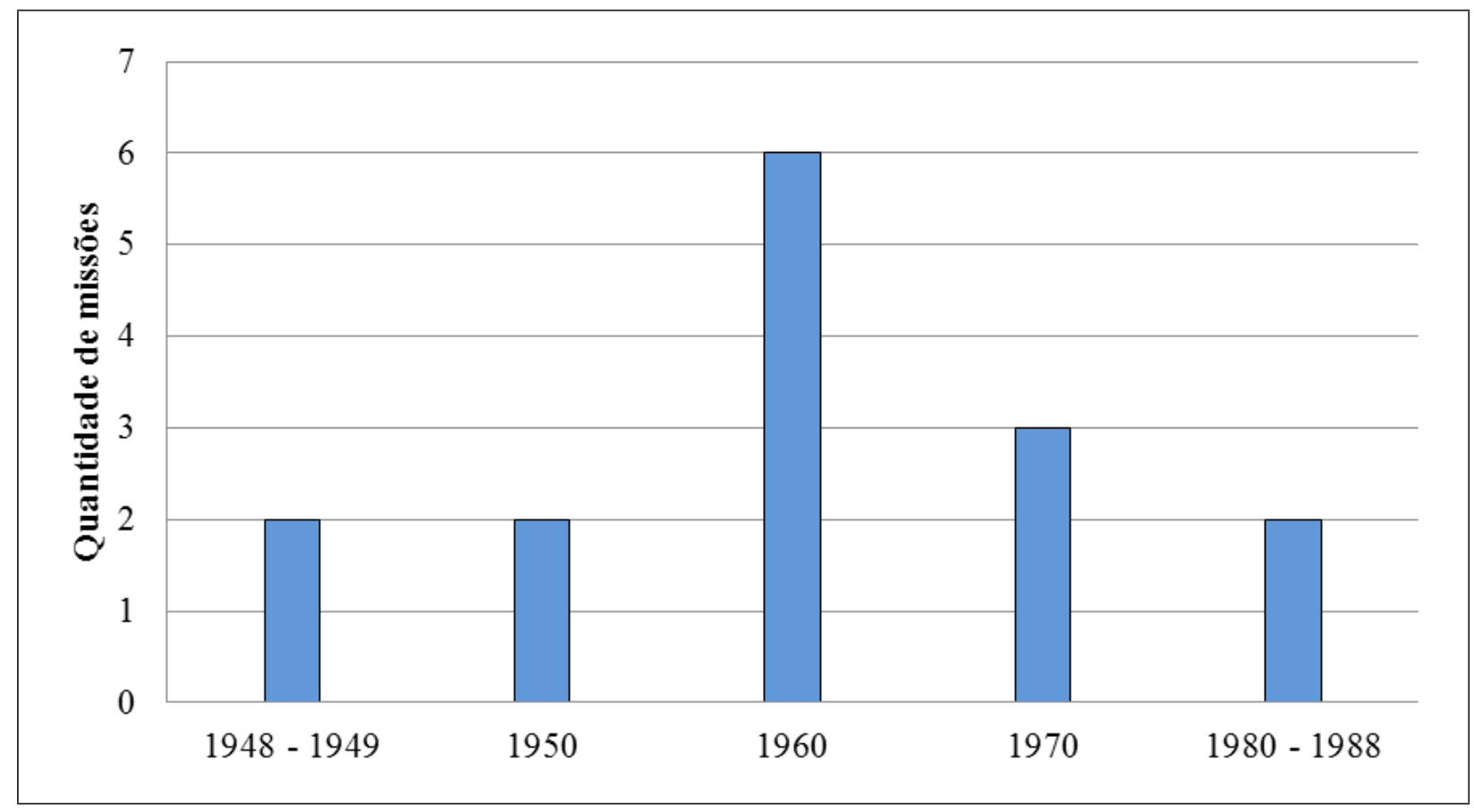

Fonte: elaboração própria, com dados do Departament of Peacekeeping Operations, 2017

Há 15 missões nesse período, sendo 6 na década de 1960. Dessas 15, 5 estão em curso atualmente: 1) UNTSO (United Nations Truce Supervision Organization), 2) UNMOGIP (United Nations Military Observer Group in India and Pakistan), 3) UNFICYP (United Nations Peacekeeping Force in Cyprus), 4) UNDOF (United Nations Disangagement Observer Force) e 5) UNIFIL (United Nations Interim Force in Lebanon). O gráfico 2 esclarece a participação brasileira no período: 


\section{Gráfico 2: Participação brasileira nas OPs de $1^{\text {a }}$ Geração}

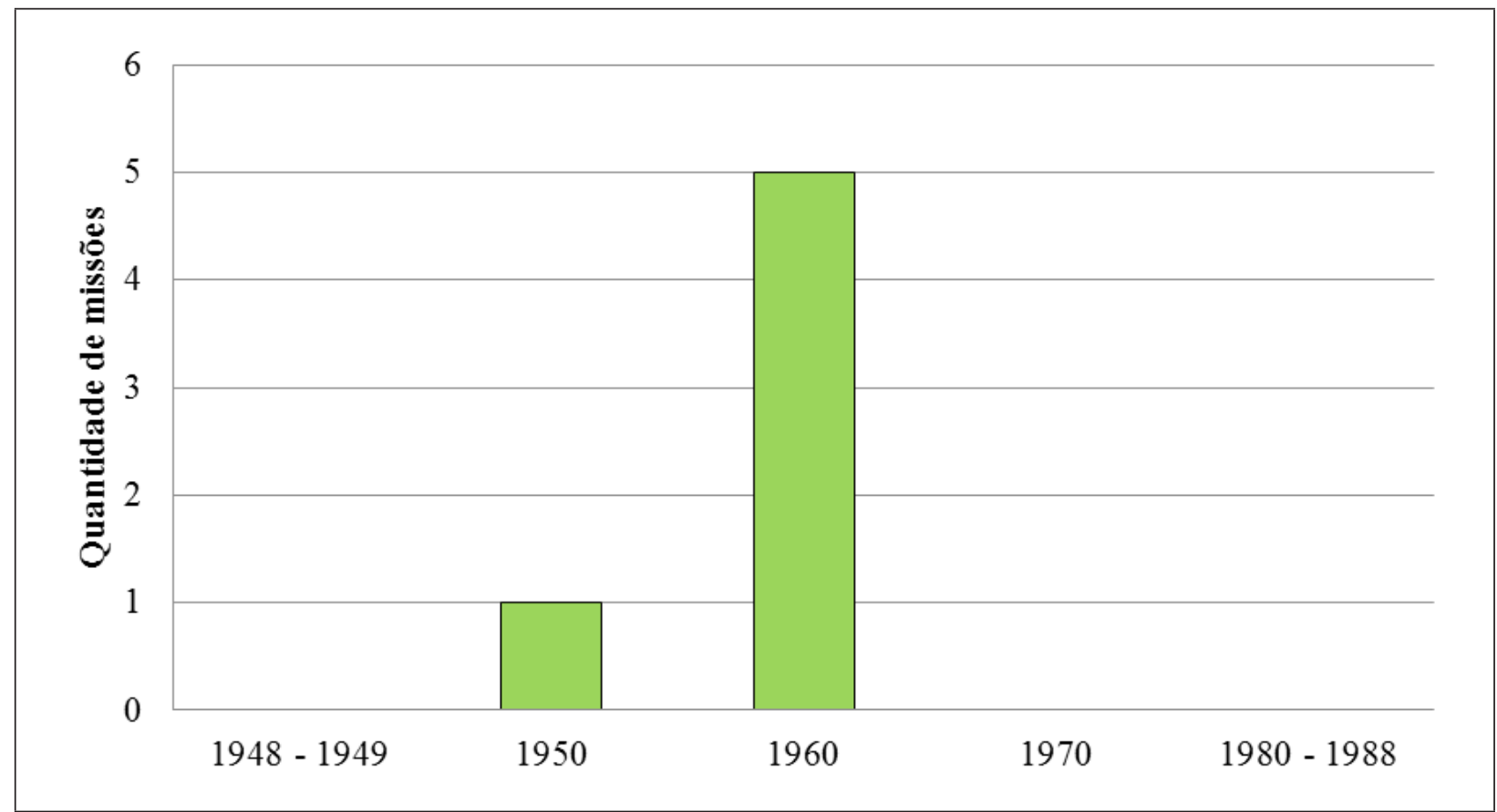

Fonte: elaboração própria, com dados do Departament of Peacekeeping Operations, 2017

Observa-se a participação brasileira em 6 missões nesse período, com 5 delas iniciando-se na década de 1960 e uma em 1956, quando houve o primeiro envio de tropas brasileiras para a região do Sinai, integrando a UNEF I (United Nations Emergency Force), a qual tinha o propósito de manter o cessar-fogo entre os egípcios e os israelenses nessa região (AGUILAR, 2005; FONTOURA, 1999).

A partir de 1967, a contribuição brasileira sofreu uma paralisia, não registrando novas participações nas décadas seguintes. Para que se tenha uma ideia mais detalhada da participação brasileira no período, cabe observar o quadro 1: 
Quadro 1: Participação brasileira em OPs de $1^{\text {a }}$ Geração

\begin{tabular}{|c|c|c|c|c|}
\hline Missão & Localização & Militares & Civis & Período \\
\hline UNEF I & Sinai e Faixa de Gaza & 6.300 & - & $1957-1967$ \\
ONUC $^{4}$ & Congo & 179 & - & $1960-1964$ \\
UNSF5 $^{5}$ & Nova Guiné Ocidental & 2 & - & 1962 \\
DOMREP $^{6}$ & República Dominicana & 1 & - & $1965-1966$ \\
UNIPOM$^{7}$ & Índia/Paquistão & 10 & - & $1965-1966$ \\
UNFICYP & Chipre & 30 & 1 & $1964-$ dias atuais \\
\hline \multicolumn{2}{|c|}{ TOTAL (brasileiros) } & $\mathbf{6 5 2 2}$ & $\mathbf{1}$ & $\mathbf{6 . 5 2 3}$ \\
\hline
\end{tabular}

Fonte: SEITENFUS, 2008; DPKO (Departament of Peacekeeping Operations), 2017.

O destaque fica por conta da UNEF I, missão de paz que mais contou com o envio de brasileiros nesse período. Sobre essa missão, Aguilar assinala que, durante um período de dez anos, o Brasil foi o único país sul-americano que manteve sua contribuição ao longo de toda a missão, enviando anualmente um batalhão de infantaria (batalhão Suez), composto por cerca de 600 homens, perfazendo um total de 6.300 militares que integraram a UNEF I (AGUILAR, 2005). Cumpre destacar também a participação do país no Congo, no âmbito da ONUC.

A participação brasileira não ficou restrita somente aos números - o país teve grande responsabilidade na evolução qualitativa nas missões de paz. Exemplo disso foi a participação do país na ONUC, quando houve o início de um caráter mais humanitário para a dinâmica das OPs, ocasião em que o contingente brasileiro exerceu inúmeras atividades, dentre as quais destacam-se o transporte de gêneros, a atividade de suprimento e até de medicamentos para a população congolesa (NASSER, 2012).

Dando mais ingredientes ao papel do Brasil para a evolução qualitativa das OPs, Kenkel assevera que o país foi o primeiro a enviar um contingente totalmente armado nas missões onusianas. Essa inovação se deu no contexto da UNEF I, marcando uma ruptura com o que estava sendo praticado até então pela ONU. Ou seja, as missões de paz até então se caracterizavam pelo emprego de pequenos grupos de observadores desarmados para monitorar o cessar-fogo entre os beligerantes (KENKEL, 2013).

4 ONUC - United Nations Operation in the Congo.

5 UNSF - United Nations Security Force in West New Guinea.

6 DOMREP - Mission of the Representative of the Secretary-General in the Dominican Republic.

7 UNIPOM - United Nations India-Pakistan Observation Mission. 
O papel do Brasil é ressaltado também por outros autores. Hillen esclarece que, ao enviar tropas armadas para a região do Sinai, o país realizou uma contribuição valiosa para a evolução doutrinária das missões de paz, iniciando uma nova forma de pensar as mesmas (HILLEN, 1998). Assim, confirma-se o caráter inovador ao empregar tropas armadas, o que definiu precedente importante e serviu de base para a evolução das futuras missões (HILLEN, 1998; BELLAMY, 2010; RIKHYE, 1974).

A par dessas contribuições, Kenkel também entende que as missões de

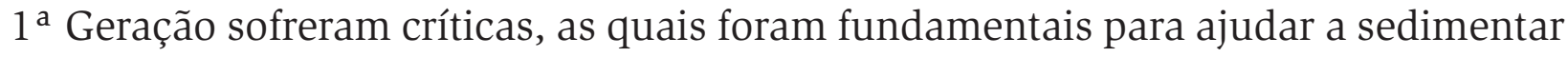
o início da nova geração de missões de paz. A principal crítica está apoiada na natureza passiva e na base rígida na solução pacífica dos conflitos dessas missões, as quais nem sempre atingiram o estado final desejado (KENKEL, 2013).

Diante desse cenário e com o término da Guerra Fria, a ONU voltou a ganhar força nas suas ações, provocando o que muitos chamaram de descongelamento das ações da ONU no sistema internacional. Esse fato fez com que as OPs voltassem a ganhar impulso, desenvolvendo novas formas e novos contornos, aplicando os ensinamentos colhidos nas missões anteriores e proporcionando uma mudança na concepção de emprego dos chamados "capacetes azuis" - as tropas das Nações Unidas. Esse ambiente proporcionou as condições favoráveis para o surgimento da chamada $2^{\text {a }}$ Geração das operações de paz.

\section{A $2^{\mathrm{a}}$ Geração das operações de paz}

O cenário internacional após a Guerra Fria gerou condições para o surgimento de conflitos que não expressavam mais uma rivalidade entre Estados, mas sim uma fricção no ambiente interno estatal, quer seja nas etnias, nas facções e até em grupos de pessoas que não aceitavam mais viver juntos (LA MAISONNEUVE, 1998).

No ambiente internacional, Hillen entende que o término da Guerra Fria gerou um reaquecimento das atividades da ONU, pois o mecanismo de vetos utilizado pelos EUA e pela ex-URSS no contexto bipolar deixou de ser adotado ao término desse período, levando a um aumento da oferta das missões de paz da ONU (HILLEN, 1998).

Diehl concorda com Hillen e nos assevera que essas transformações no mundo resultaram num aumento do emprego de OPs por parte da ONU, com profundas 
mudanças na natureza e na extensão das missões de paz (DIEHL, 2008). Foi nesse sentido que as missões onusianas ganharam um novo impulso e se tornaram a principal ferramenta da ONU para garantir a segurança ao redor do planeta, dando início à $2^{\text {a }}$ Geração das operações de paz, que teve início após a queda do muro de Berlim e se estende até os dias atuais.

Foi nessa atmosfera que o CSNU passou a autorizar missões cada vez mais complexas, abarcando várias funções e atividades e assim surgiram as OPs chamadas de $2^{\text {a }}$ Geração ${ }^{8}$, com mandatos orientados à prestação de ajuda humanitária, verificação da situação dos direitos humanos, policiamento ostensivo, supervisão de eleições, auxílio à administração pública, restauração da infraestrutura e do setor econômico, além dos objetivos tradicionais (BIGATÃO, 2007).

No que concerne às tarefas realizadas por essas missões, Fountoura nos ensina que as missões de $2^{\text {a }}$ Geração tinham como foco a resolução do conflito e a reconstrução do país hospedeiro, incorporando tarefas realizadas por civis e por militares, atuando na reconstrução do país em áreas e setores como eleições, direitos humanos, administração pública, gerenciamento econômico, assistência humanitária, atividades policiais e militares (FONTOURA, 2005).

Posicionando-se oficialmente, a ONU assinala que as missões de paz de

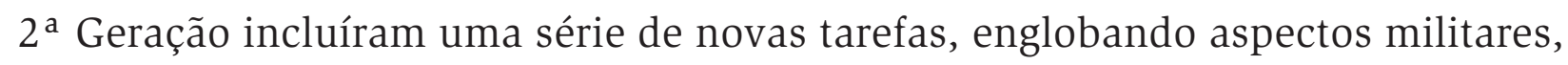
aspectos políticos, preocupação humanitária e com o desenvolvimento do país hospedeiro. A busca por uma paz duradoura, querendo evitar os erros verificados nas OPs de $1^{\text {a }}$ Geração, nortearam as ações da ONU nessa época (DPKO/DFS, 2008).

Em meio a essas mudanças no cenário internacional, o secretário-geral da ONU Boutros Boutros-Ghali elaborou um documento chamado Agenda para a Paz, o qual ampliou as missões de paz sob o ponto de vista conceitual, passando a incluir atividades como a diplomacia preventiva, a imposição da paz e a construção da paz (BOUTROS-GHALI, 1992).

Silva nos assevera que um dos problemas decorrentes do alargamento das tarefas relacionadas ao mandato foi o surgimento de uma lacuna entre os objetivos a serem atingidos pela missão e aquilo que, efetivamente, as operações de paz poderiam executar na prática, tanto em termos legais como materiais (SILVA, 2012).

Sob outra perspectiva, Kenkel observa que as missões de paz nesse período foram quase sempre implementadas sob os auspícios do capítulo VI da Carta das Nações Unidas, ou seja, não foram realizadas mudanças operacionais nas regras

8 As OPs de $2^{\text {a }}$ Geração também são chamadas de operações multidisciplinares, multidimensionais ou multifuncionais. 
de engajamento dos militares para atender o alargamento das atividades assumidas pelo contingente da ONU (KENKEL, 2013).

Diante dessa realidade, alguns estudiosos entendem que o sucesso dessas missões dependeria ora da boa vontade das partes em conflito, ora do peso da persuasão moral da ONU. Com isso, verificou-se que nem todas as missões nesse período lograram o êxito esperado, pelo contrário, algumas obtiveram grande fracasso e serviram de base para o emolduramento das gerações de missões futuras.

Bigatão põe ingredientes nessa discussão ao inferir que muitos analistas entenderam que a ONU atingiu resultados satisfatórios em algumas áreas, mas que não foi capaz de obter êxito na execução completa dos mandatos das missões multidisciplinares, conforme ocorrido na Namíbia, em Moçambique, em Angola e no Camboja (BIGATÃO, 2007).

Assim, Kenkel aponta o esgotamento do aparato onusiano, tanto no campo operacional quanto financeiro e institucional, fazendo com que a ONU registrasse três grandes fracassos em OPs na década de 1990: 1) o despreparo da ONU em prevenir ou limitar o genocídio de Ruanda em 1994; 2) a ineficácia da ONU na concretização de um acordo político, juntamente com as perdas militares, relativamente pesadas, na Somália; e 3) a incapacidade da ONU em proteger os civis na Bósnia, simbolizado pelo massacre de Srebrenica de 1995 (KENKEL, 2013).

Sob essa ótica de erros e acertos - ou fracassos e êxitos - é que se desenvolveram as missões de paz da $2^{\text {a }}$ Geração. Destacam-se ainda o descongelamento das ações da ONU e uma preocupação cada vez maior dessa instituição e da sociedade com a segurança do ser humano nos mais variados níveis.

Outra característica importante desse período se apoia no aumento das tarefas e atividades da ONU no país hospedeiro, sem recebimento do devido apoio estrutural, jurídico e financeiro por parte do CSNU para dar cabo dessas múltiplas demandas. O gráfico 3 apresenta as OPs de $2^{\text {a }}$ Geração: 
Gráfico 3: OPs de $2^{\mathrm{a}}$ Geração

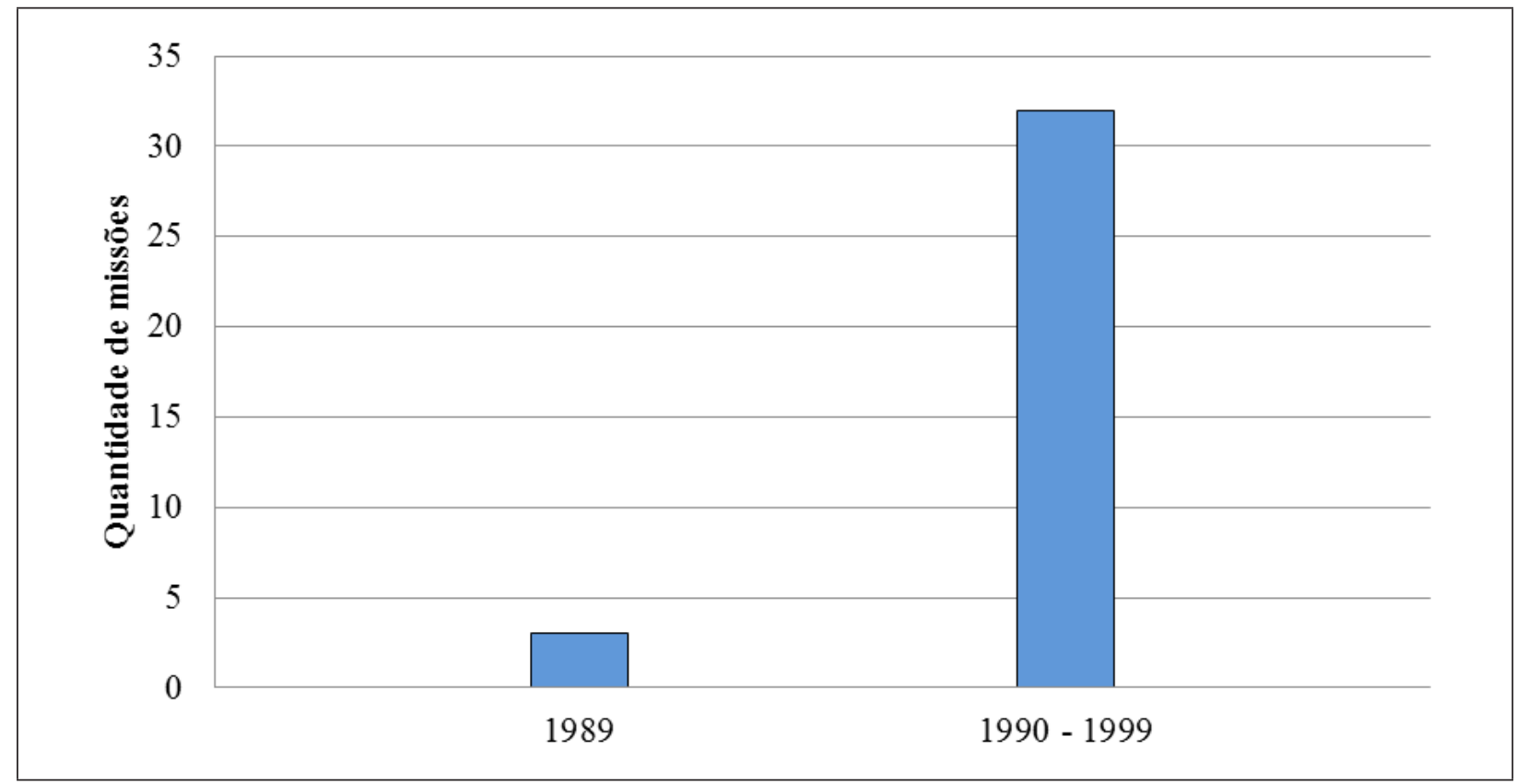

Fonte: elaboração própria, com dados do Departament of Peacekeeping Operations, 2017.

Observa-se que o número de missões de paz aumentou potencialmente, registrando 35 missões em pouco mais de 10 anos. Desse total, cabe destacar que existe uma missão de $2^{\text {a }}$ Geração ainda em curso: MINURSO (United Nations Mission for the Referendum in Western Sahara).

Dissecando ainda mais esses números, três missões da $2^{\text {a }}$ Geração tiveram início em 1989: UNAVEM I (United Nations Angola Verification Mission I), ONUCA (United Nations Observer Group in Central America) e UNTAG (United Nations Transition Assistance Group). E as outras 32 se iniciaram na década de 1990.

Ademais, ressalta-se que há três missões que se iniciaram na década de 1990 e que não foram classificadas como de $2^{\text {a }}$ Geração, pois não apresentaram características para tal: UNMIK (United Nations Interim Administration Mission in Kosovo), UNTAET (United Nations Transitional Administration in East Timor) e MONUC (United Nations Organization Mission in the Democratic Republic of the Congo).

O término da Guerra Fria e o descongelamento das ações da ONU não só aumentaram a participação da instituição no sistema internacional, como fizeram com que o Brasil acompanhasse tal tendência, à época.

Sendo assim, a participação brasileira nesse período também seguiu a tendência de alta da ONU, fazendo com que a década de 1990 presenciasse um crescimento robusto do Brasil nas OPs. O gráfico 4 apresenta a participação brasileira nas missões de paz de $2^{\text {a }}$ Geração: 


\section{Gráfico 4: Participação brasileira em OPs de $2^{a}$ Geração}

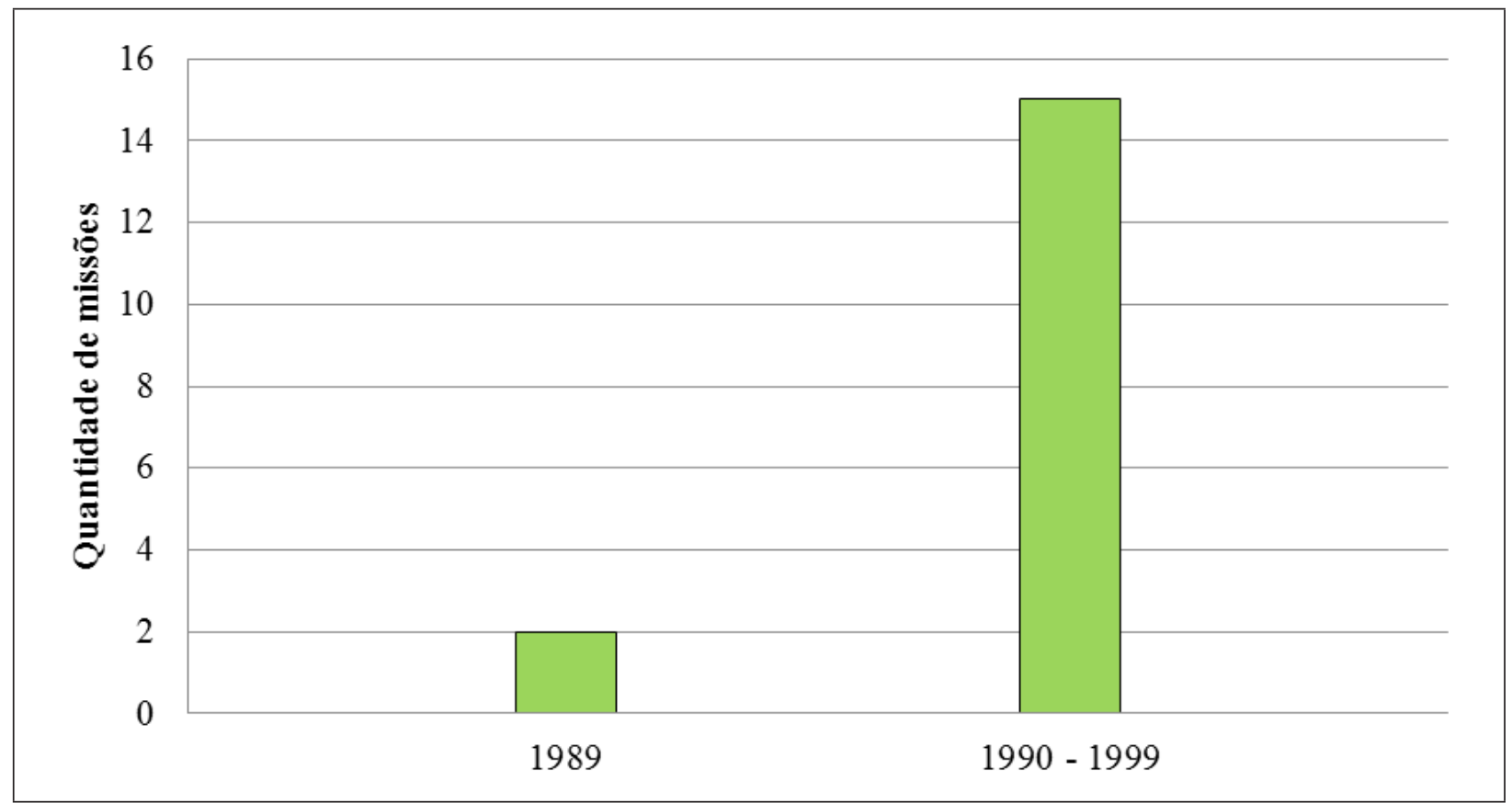

Fonte: elaboração própria, com dados do Departament of Peacekeeping Operations, 2017.

Nota-se que o Brasil participou de 17 missões num período de pouco mais de 10 anos. Ao comparar a participação brasileira nas missões de $1^{\mathrm{a}}$ e $2^{\mathrm{a}}$ gerações, verifica-se um aumento de quase 200\%. Ressalta-se que o crescimento da participação do país em missões de paz é bem superior ao crescimento obtido pela ONU em realização de missões de paz, que foi de quase 100\% . Como nas missões de $1^{\text {a }}$ Geração, o Brasil continuou em destaque. Confirmando a contribuição brasileira em termos qualitativos para as missões de paz, Castelo Branco aponta que o relatório final realizado pelo representante especial do secretário-geral da ONU, o italiano Aldo Ajello, mostra que o mandato da ONUMOZ (United Nations Operation in Mozambique) foi exitoso, destacando o papel dos capacetes azuis na aplicação do acordo geral de paz, assinado em 04 de outubro de 1992, na realização de assistência humanitária, na assistência técnica e culminando no apoio à realização das eleições livres no país (CASTELO BRANCO, 2003).

Colares acrescenta elementos adicionais ao tema, lembrando que a ONUMOZ foi importante para o Brasil, pois foi nessa missão que o país voltou a empregar suas tropas em OPs, inclusive designando um brasileiro para o cargo de Force Comander na ONUMOZ, função exercida pelo general Lélio Rodrigues da Silva entre fevereiro de 1993 e fevereiro de 1994 (COLARES, 2014). Para que se tenha uma ideia mais pormenorizada da participação brasileira nas OPs de $2^{\text {a }}$ Geração, apresenta-se o quadro 2: 
Quadro 2: Participação brasileira em OPs de $2^{\mathrm{a}}$ Geração

\begin{tabular}{|c|c|c|c|c|c|}
\hline Missão & Localização & Militares & Policiais & Civis & Período \\
\hline UNAVEM I & Angola & 24 & - & - & $1989-1991$ \\
\hline ONUCA & América Central & 47 & - & - & $1989-1992$ \\
\hline UNAVEM II ${ }^{9}$ & Angola & 104 & 50 & 14 & $1991-1995$ \\
\hline ONUSAL ${ }^{10}$ & El Salvador & 54 & 17 & - & $1991-1995$ \\
\hline MINURSO & Saara Ocidental & 92 & - & - & 1991 - dias atuais \\
\hline ONUMOZ & Moçambique & 225 & 65 & 16 & $1992-1994$ \\
\hline UNTAC 11 & Camboja & - & - & 19 & $1992-1993$ \\
\hline UNOMSA $^{12}$ & África do Sul & - & - & 12 & $1992-1994$ \\
\hline UNPROFOR ${ }^{13}$ & Ex-Iugoslávia & 82 & 16 & - & $1992-1995$ \\
\hline UNOMUR ${ }^{14}$ & Ruanda/Uganda & 23 & - & - & $1993-1994$ \\
\hline UNOMIL 15 & Libéria & 3 & - & - & $1993-1997$ \\
\hline $\mathrm{UNCRO}^{16}$ & Croácia & 14 & 2 & - & $1995-1996$ \\
\hline UNAVEM III'17 & Angola & 4.174 & 48 & - & $1995-1997$ \\
\hline UNPREDEP18 & Macedônia & 7 & - & - & $1995-1999$ \\
\hline UNTAES 19 & Eslovênia/Oriental & 12 & 2 & - & $1996-1998$ \\
\hline UNMOP20 & Pevlalka & 6 & - & - & $1996-2002$ \\
\hline MINUGUA 21 & Guatemala & 18 & 13 & - & 1997 \\
\hline MONUA'22 & Angola & 15 & 33 & - & $1997-1999$ \\
\hline \multicolumn{2}{|c|}{ TOTAL } & 4.920 & 286 & 61 & 5267 \\
\hline
\end{tabular}

Fonte: elaboração própria, com dados do Departament of Peacekeeping Operations, 2017.

Percebe-se a maior participação de policiais e civis brasileiros nas missões onusianas, confirmando a preocupação da ONU com a paz duradoura, com foco na gestão do conflito e não mais na simples resolução do mesmo. Com um

\footnotetext{
9 UNAVEM II - United Nations Angola Verification Mission II.

10 ONUSAL - United Nations Observer Mission in El Salvador.

11 UNTAC - United Nations Transitional Authority in Cambodia.

12 UNOMSA - United Nations Observer Mission in South Africa.

13 UNPROFOR - United Nations Protection Force.

14 UNOMUR - United Nations Observer Mission Uganda-Rwanda.

15 UNOMIL - United Nations Observer Mission in Liberia.

16 UNCRO - United Nations Confidence Restoration Operation in Croatia.

17 UNAVEM III - United Nations Angola Verification Mission III.

18 UNPREDEP - United Nations Preventive Deployment Force.

19 UNTAES - United Nations Transitional Administration for Eastern Slavonia, Baranja and Western Sirmium.

20 UNMOP - United Nations Mission of Observers in Prevlaka.

21 MINUGUA - United Nations Verification Mission in Guatemala. Período de janeiro à maio de 1997.

22 MONUA - United Nations Observer Mission in Angola.
} 
efetivo de 286 policiais e de 61 civis brasileiros, o país seguiu essa tendência e se adequou ao alargamento do rol de tarefas requeridas pela ONU para a restauração da paz nos locais em conflito. Verifica-se, também, o papel de destaque exercido pelo Brasil na UNAVEM III, ocorrida em Angola, envolvendo 4.174 militares e 48 policiais brasileiros entre 1995 e 1997. A designação do general Lélio Rodrigues da Silva como Force Comander na ONUMOZ descortina outros tipos de contribuição brasileira às OPs, as chamadas Token Troop Contributions.

A $2^{\text {a }}$ Geração das OPs proporcionou ensinamentos para as futuras gerações, seguindo uma tendência verificada já na $1^{\text {a }}$ Geração. Nesse contexto, Kenkel nos assevera que cada uma das missões ocorridas nesse período foi capaz de gerar ensinamentos nos princípios da manutenção da paz, levando ao surgimento de uma $3^{\text {a }}$ Geração de operações de paz (KENKEL, 2013). Sendo assim, pode-se inferir que as missões de $3^{\text {a }}$ Geração surgem da evolução natural da $2^{\text {a }}$ Geração, refletindo novamente o ambiente internacional de sua época e seus reflexos para a evolução das OPs.

\section{A $3^{\mathrm{a}}$ Geração das operações de paz}

Os fracassos da ONU em Ruanda, na Somália e na Bósnia chamaram a atenção da comunidade internacional, fazendo com que a mesma se debruçasse sobre o tema com o objetivo de encontrar respostas para o ocorrido. Bigatão assinala que o fracasso em tais operações fez com que o Secretário-Geral da ONU, Kofi Annan, solicitasse a um grupo de estudiosos internacionais uma revisão dos temas relativos às missões de paz, cujos resultados foram concentrados num documento chamado de Relatório Brahimi (BIGATÃO, 2007).

Esse documento foi o motor necessário para que a $3^{\text {a }}$ Geração ganhasse forma e contorno e se distinguisse da $2^{\text {a }}$ Geração das operações de paz. Nesse sentido, o Relatório Brahimi se tornou um documento fundamental para a compreensão da natureza e do funcionamento das OPs da atualidade. Williams destaca o papel exercido pelo Relatório Brahimi ao assinalar que, após os fracassos da ONU na Somália e em Serra Leoa, as missões de paz teriam que ser suficientemente fortes para impedir que os oponentes atacassem os integrantes da ONU, além de garantir a segurança dos civis na região (WILLIAMS, 2010).

Foi nesse contexto que surgiram as OPs de $3^{\mathrm{a}}$ Geração, as quais tiveram início no final da década de 1990 e se estendem até os dias atuais. A diferença mais flagrante das OPs de $3^{\text {a }}$ Geração para as missões de $2^{\text {a }}$ Geração é a autorização 
do uso da força pelas tropas da ONU. Nessa linha de pensamento, Osman destaca que essas missões foram caracterizadas pelo aumento do uso da força para atingir os objetivos propostos pelo mandato da ONU (OSMAN, 2002).

Aguilar também assevera que os mandatos da organização supranacional passaram a utilizar maior uso da força pelo componente militar e insere ingredientes ao inferir que as OPs de $3^{\text {a }}$ Geração demandavam um emprego cada vez maior do componente civil da ONU na região do conflito (AGUILAR, 2015). O gráfico 5 apresenta o número total de OPs de $3^{\text {a }}$ Geração:

\section{Gráfico 5: OPs de $3^{\mathrm{a}}$ Geração}

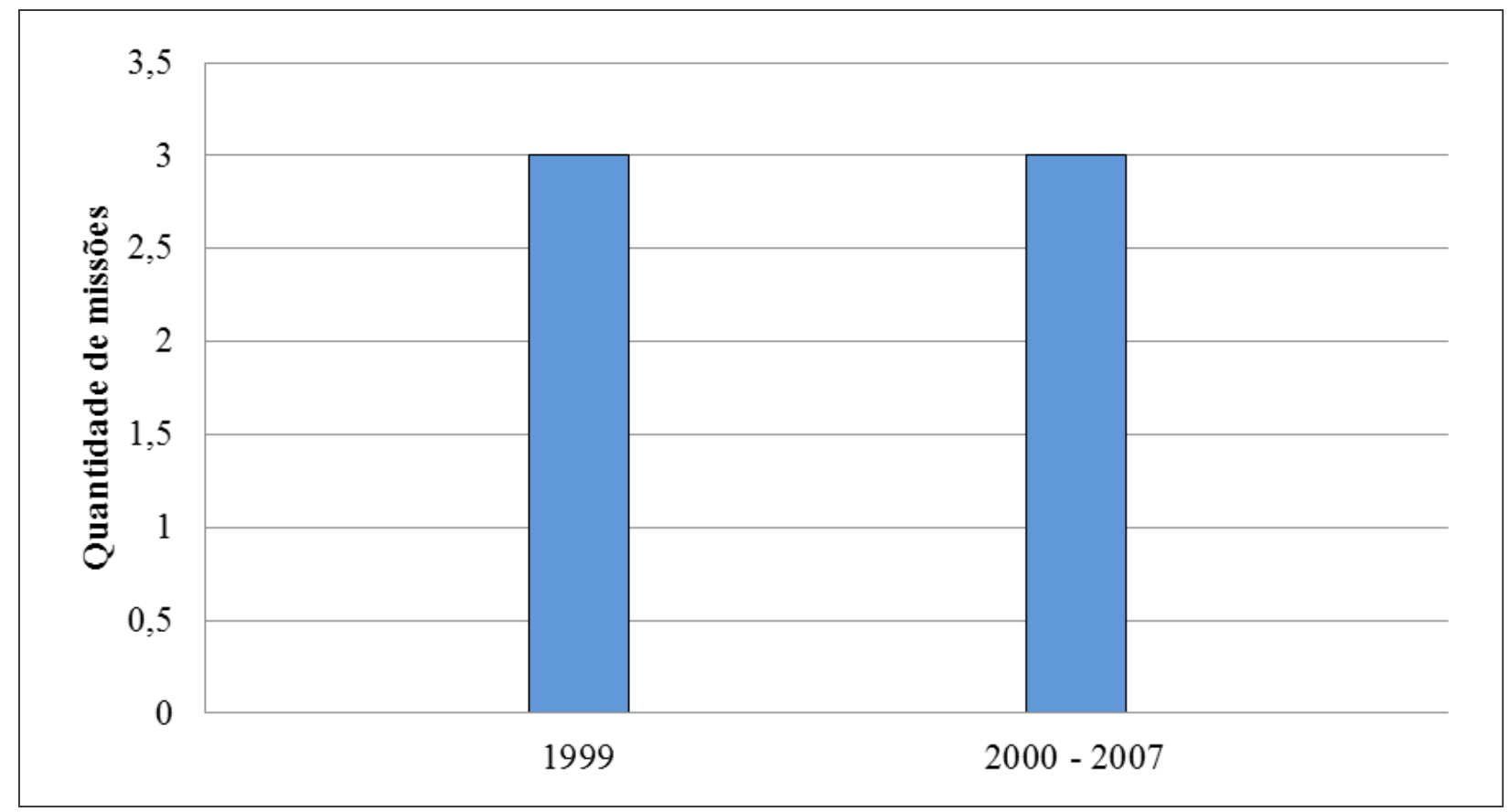

Fonte: elaboração própria, com dados do Departament of Peacekeeping Operations, 2017.

De acordo com o gráfico, há seis missões de paz de $3^{\text {a }}$ Geração. Das seis, uma não se iniciou nesse período: a UNIFIL, que teve início em 1978 e que, até 2006, era uma missão de $1^{\text {a }}$ Geração - com a resolução $n^{0}$ 1701, de 2006, do CSNU, essa missão passou a integrar a $3^{\text {a }}$ Geração de operações de paz, pelo mandato mais robusto a que foi submetida.

As demais missões são as seguintes: 1) UNMIK (United Nations Interim Administration Mission in Kosovo), 2) UNTAET (United Nations Transitional Administration in East Timor), 3) MONUC (United Nations Organization Mission in the Democratic Republic of the Congo), 4) UNMISET (United Nations Mission of Support in East Timor) e 5) MINURCAT (United Nations Mission in the Central African Republic and Chad). 
Gráfico 6: Participação brasileira em OPs de $3^{\text {a }}$ Geração

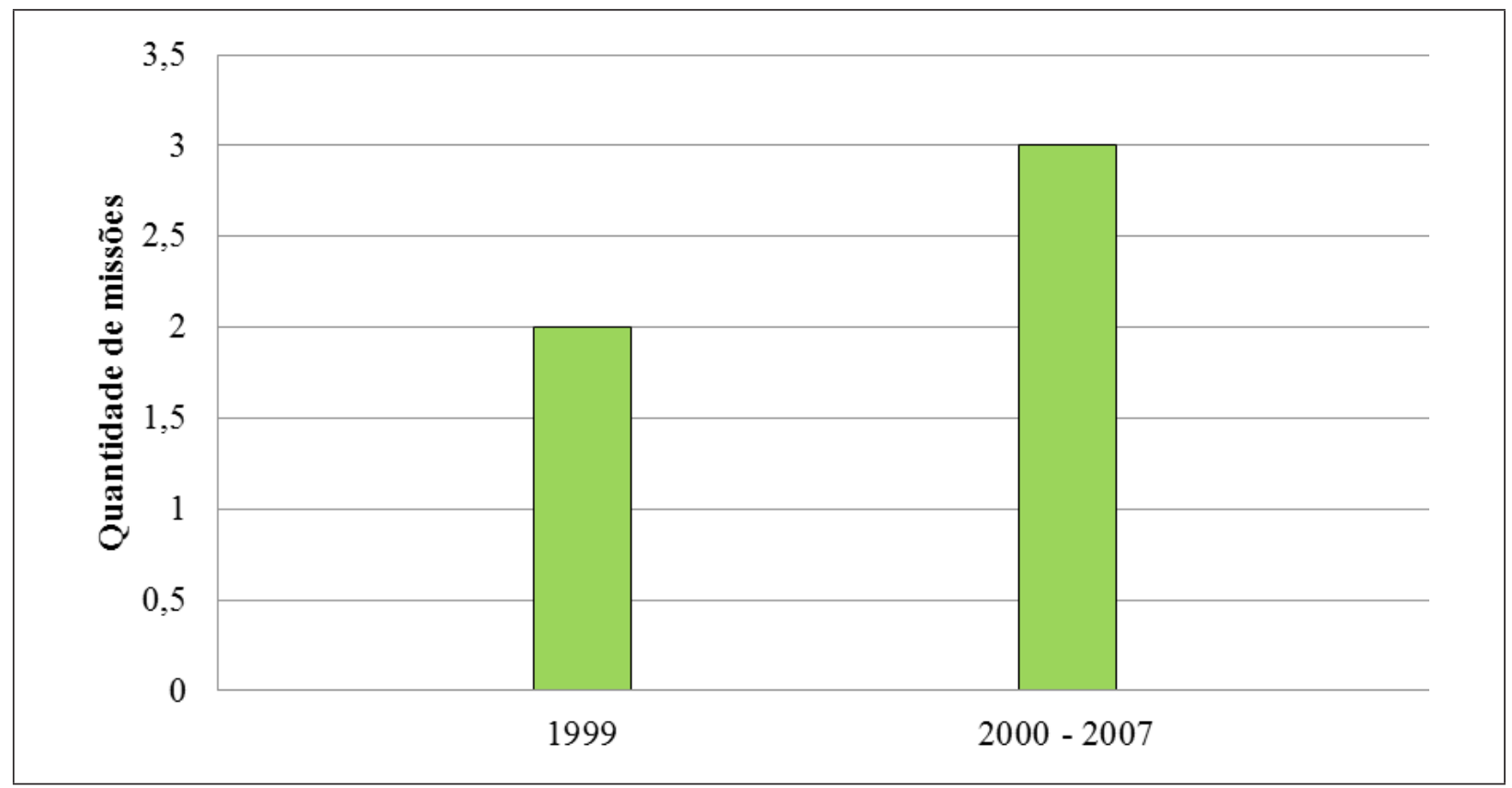

Fonte: elaboração própria, com dados do Departament of Peacekeeping Operations, 2017.

Complementando as informações do gráfico, o quadro 3 detalha a participação brasileira nas OPs de $3^{\text {a }}$ Geração:

Quadro 3: Participação brasileira em OPs de $3^{\text {a }}$ Geração

\begin{tabular}{|c|c|c|c|c|c|}
\hline Missão & Localização & Militares & Policiais & Civis & Período \\
\hline UNTAET & Timor Leste & 174 & 25 & - & $1999-2002$ \\
UNMIK & Kosovo & - & 15 & - & $1999-$ dias atuais \\
UNMISET & Timor Leste & 274 & 17 & 19 & $2002-2005$ \\
& África Central e & 06 & - & - & $2007-2010$ \\
MINURCAT & República do Chade & 1496 & - & - & $1978-$ dias atuais \\
UNIFIL & Líbano & $\mathbf{1 9 5 0}$ & $\mathbf{5 7}$ & $\mathbf{1 9}$ & $\mathbf{2 0 2 6}$ \\
\hline \multicolumn{2}{|c|}{ TOTAL (brasileiros) }
\end{tabular}

Fonte: elaboração própria, com dados do Departament of Peacekeeping Operations, 2017.

O quadro 4 evidencia a importância da UNIFIL para o Brasil, pois contou com a participação de 1496 militares brasileiros, sendo a maioria pertencente à Marinha. E o destaque não reside somente nesses números. Abdenur ressalta a liderança exercida pela Marinha do Brasil na força-tarefa marítima no Líbano. Esse fato fez com que o Brasil se tornasse o primeiro país não membro da OTAN a comandar uma força-tarefa marítima em operações de paz sob a égide da ONU. Assim, nos dias atuais, o Brasil comanda uma esquadra no Líbano composta por 
sete navios: dois de Bangladesh, um da Grécia, um da Indonésia, um da Alemanha, um da Turquia e a nau capitânia brasileira, com substituição a cada seis meses do efetivo empregado pelo Brasil na UNIFIL (ABDENUR, 2016).

Já Penna ressalta a contribuição brasileira na UNTAET, onde o brasileiro Sérgio Vieira de Mello foi nomeado, pela resolução 1272 da ONU, para exercer a autoridade transitória no Timor Leste, com domínio sobre os poderes executivo, legislativo e de segurança do país (PENNA, 2009). Seitenfus também enaltece a contribuição brasileira no Timor Leste, reforçando que a contribuição brasileira englobou vários campos do poder: 1) a presença de militares no campo tático, 2) a liderança política brasileira exercida por Sérgio Vieira de Mello, no contexto da UNTAET (Administração Transitória das Nações Unidas para o Timor Leste) e 3) a contribuição do Brasil no campo social, envolvendo as áreas da saúde, da educação, da agricultura e da justiça, confirmando o caráter multidimensional e o sucesso alcançado (SEITENFUS, 2008).

Sendo assim, pode-se compreender que a combinação do uso elevado da força, caracterizado pela inclusão de uma força-tarefa marítima no Líbano, bem como o aumento nas tarefas civis nos mandatos transitórios, emolduraram a base necessária para o surgimento da $4^{a}$ Geração das operações de paz.

\section{A $4^{\mathrm{a}}$ Geração das operações de paz}

Para Bellamy, a $4^{\text {a }}$ Geração das OPs consiste na consolidação robusta das OPs de $3^{\text {a }}$ Geração, ao combinar a permissão para usar a força com a autorização para exercer tarefas civis complexas, proporcionando condições satisfatórias para a efetiva reconstrução do país hospedeiro (BELLAMY et al., 2010). Sendo assim, conclui-se que a $4^{\text {a }}$ Geração das OPs nasceu, praticamente, do aperfeiçoamento da geração anterior.

E, nesse aspecto, destaca-se o papel do Brasil nessa geração de OPs. Motivada por algumas intervenções externas que agravaram ainda mais a sensação de insegurança em países hospedeiros, a presidente Dilma Rousseff fez uma proposta, em 2011, na sede da ONU, provocando os países a refletirem e discutirem sobre o conceito de responsabilidade "ao" proteger, fruto da evolução do conceito anterior existente que era de responsabilidade "de" proteger.

Barnett relata que a origem doutrinária da $4^{\text {a }}$ Geração das OPs teve sua semente plantada em 1994, quando o secretário-geral da ONU, Boutros Boutros-Ghali, se 
pronunciou publicamente definindo o conceito de peacebuilding ${ }^{23}$ pós-conflito em um suplemento da agenda para a paz (BARNETT; ZURCHER, 2009). Na visão do então secretário-geral da ONU, a construção ou reconstrução de determinadas estruturas fortaleceriam o processo de paz no país hospedeiro e evitariam uma recaída durante tal processo. Assim, a $4^{\text {a }}$ Geração passou a ser conhecida como OPs de construção da paz.

Richmond entende que essas missões se caracterizam, na sua essência, em prevenir formas de violência direta ou indireta por meio da reconstrução ou construção de determinadas estruturas no país hospedeiro, as quais fortalecerão o processo de paz (RICHMOND, 2004). Mas entender as OPs de $4^{\text {a }}$ Geração não é tarefa simples. Para Barnett, há três dimensões de peacebuilding pós-conflito: 1) criação de estabilidade; 2 ) restauração de instituições estatais; e 3) direcionamento das dimensões socioeconômicas do conflito (BARNETT; ZURCHER, 2009).

Christie assevera que essas missões marcaram uma mudança significativa nas metas de intervenção internacional, pois as mesmas preconizam a reestruturação dos sistemas político e econômico do país hospedeiro, de tal forma que as mesmas promovam a satisfação equitativa e sustentável das necessidades humanas (CHRISTIE, 2006). Diante desse alargado rol de tarefas e definições, será mostrado o gráfico 7 , com o número total de OPs de $4^{\text {a }}$ Geração:

\section{Gráfico 7: OPs de $4^{\mathrm{a}}$ Geração}

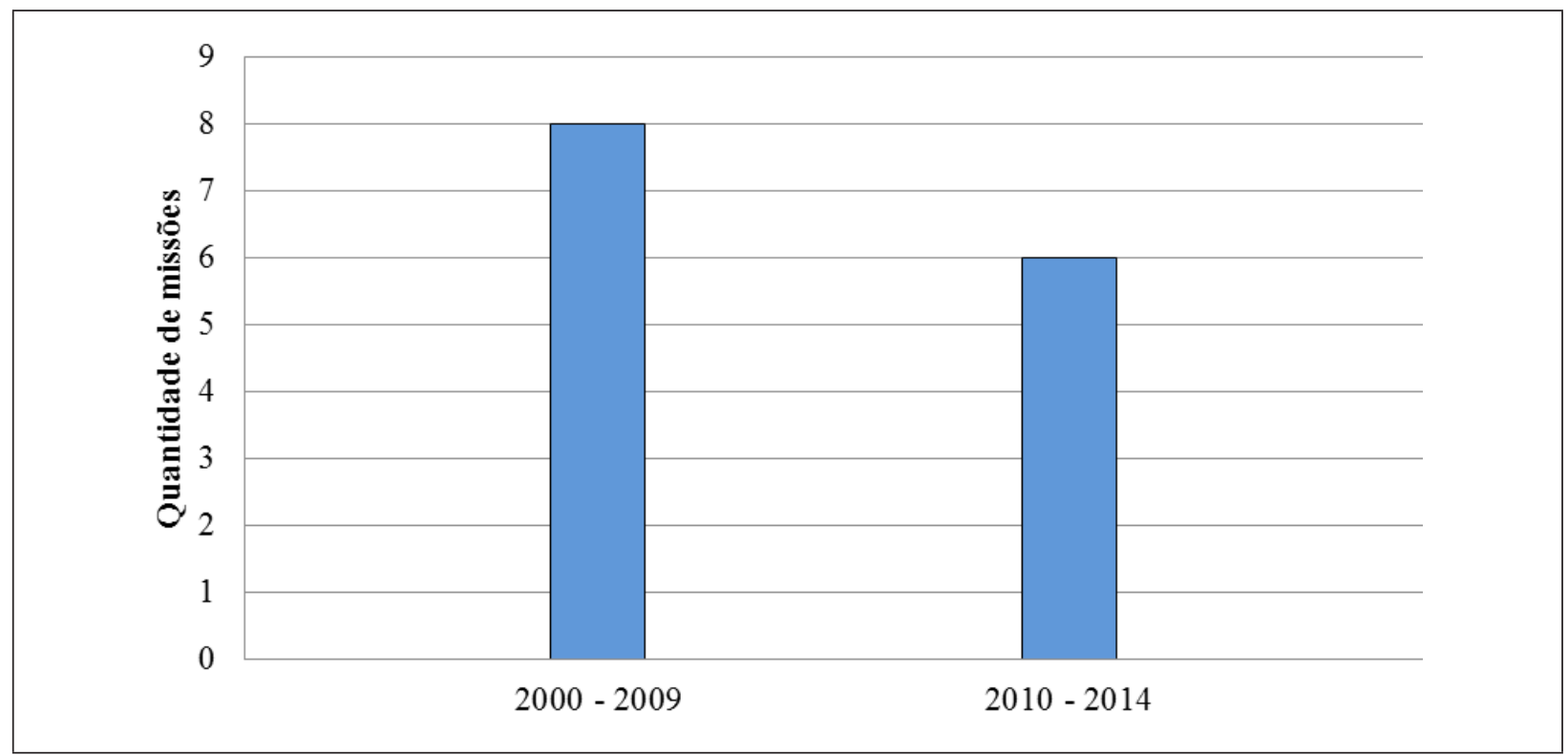

Fonte: elaboração própria, com dados do Departament of Peacekeeping Operations, 2017.

23 Peacebuilding - conceito definido pela Agenda Para a Paz, em 1992: Tradução própria — "uma ação para identificar e suportar estruturas que tendem a fortalecer e solidificar a ordem de paz para evitar uma recaída no conflito" (UN, 1992). Do original em inglês - "an action to identify and support structures whichtend to strenghten and solidify peacein order to avoid a relapse into conflict" (UN, 1992). 
O gráfico revela que há 14 missões na $4^{\text {a }}$ Geração das operações de paz. Dessas, 6 já terminaram suas atividades e 8 ainda estão em andamento. No que concerne ao papel do Brasil nesse período, o gráfico a seguir apresenta a participação brasileira:

Gráfico 8: Participação brasileira em OPs de $4^{\text {a }}$ Geração

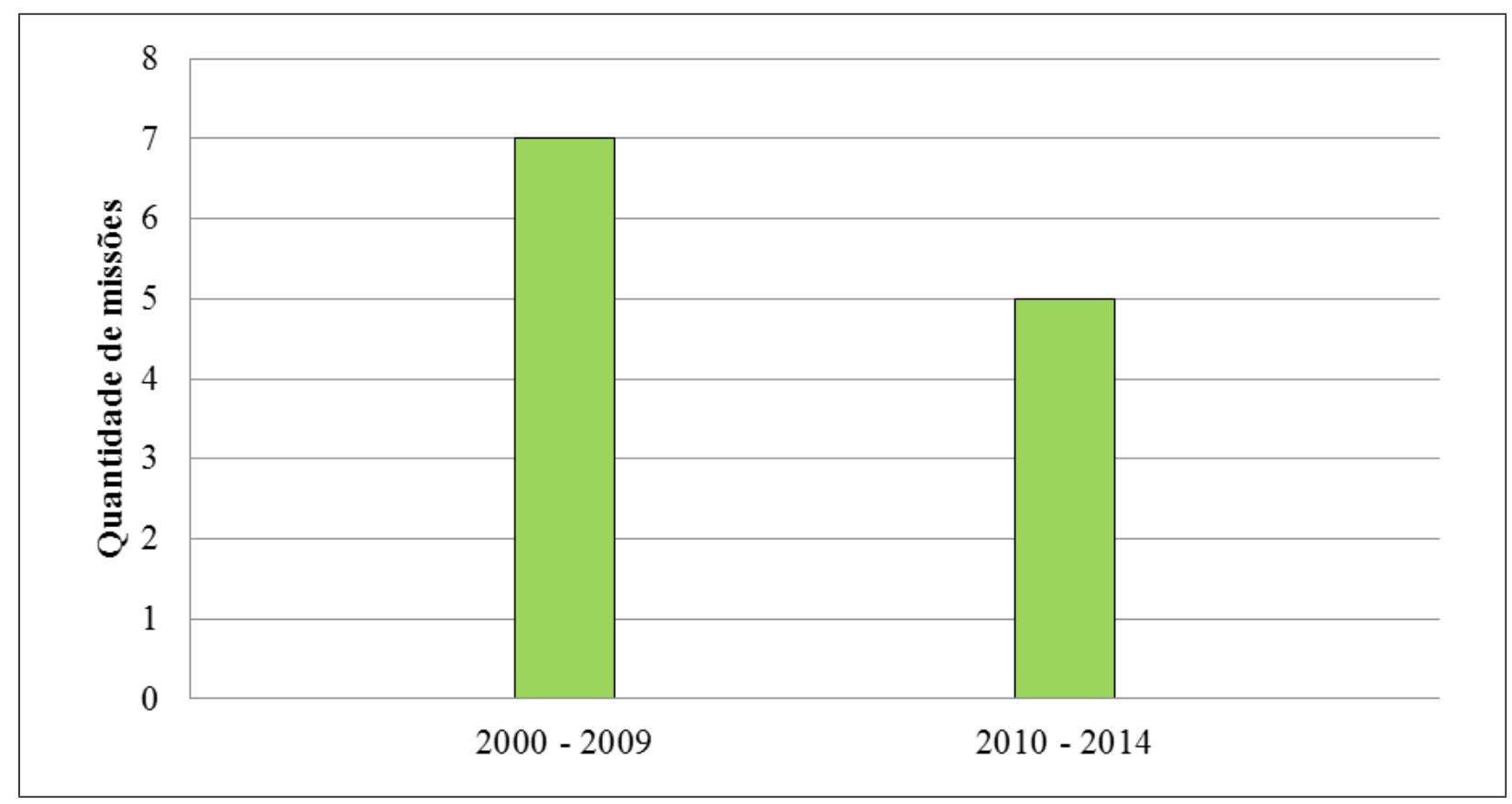

Fonte: elaboração própria, com dados do Departament of Peacekeeping Operations, 2017.

Registra-se a participação do país em 12 OPs de $4^{\mathrm{a}}$ Geração, o que reflete um expressivo aumento em comparação com a participação brasileira na geração anterior. Porém, não foi só quantitativa a contribuição brasileira nesse período.

O papel do Brasil na crise haitiana não ficou limitado somente ao envio de forças militares e no protagonismo do comando da MINUSTAH. Segundo Nasser, o país destinou recursos para a reconstrução do Haiti e ajudou na realização de eleições presidenciais e outras tarefas adicionais, evidenciando a preocupação brasileira na reorganização das instituições democráticas haitianas (NASSER, 2012). Além disso, a MINUSTAH demonstrou a excelente cooperação e harmonia das forças armadas sul-americanas em operações militares combinadas. Esse trabalho em conjunto possibilitou que a expressão militar da missão pudesse ajudar o Brasil no projeto político brasileiro de melhor conformar sua área de influência e consolidar sua liderança regional (PACHECO; MIGON, 2013). Para que se tenha uma ideia mais detalhada do papel do Brasil na $4^{\text {a }}$ Geração das OPs, será mostrado o quadro 4: 


\section{Quadro 4: Participação brasileira em OPs de $4^{\mathrm{a}}$ Geração}

\begin{tabular}{|c|c|c|c|c|}
\hline Missão & Localização & Militares & Policiais & Período \\
\hline UNMEE $^{24}$ & Etiópia e Eritréia & 12 & - & $2000-2008$ \\
\hline UNMIL 25 & Libéria & 38 & - & 2003 - dias atuais \\
\hline UNOCI 26 & Costa do Marfim & 73 & - & 2004 - dias atuais \\
\hline MINUSTAH & Haiti & 18.422 & 96 & 2004 - dias atuais \\
\hline UNMIS27 & Sudão & 141 & 16 & $2005-2011$ \\
\hline UNMIT28 & Timor Leste & 30 & 61 & $2005-2012$ \\
\hline UNMIN29 & Nepal & 33 & - & $2007-2011$ \\
\hline MONUSCO 30 & Congo & 13 & - & 2010 - dias atuais \\
\hline UNISFA $^{31}$ & Abyel & 15 & - & 2011 - dias atuais \\
\hline UNMISS 32 & Sudão do Sul & 53 & 16 & 2011 - dias atuais \\
\hline UNSMIS 33 & Síria & 1 & - & $2012-2012$ \\
\hline MINUSCA 34 & África Central & 20 & - & 2014 - dias atuais \\
\hline \multicolumn{2}{|c|}{ TOTAL (brasileiros) } & 16.859 & 169 & 17.028 \\
\hline
\end{tabular}

Fonte: elaboração própria, com dados do Departament of Peacekeeping Operations, 2017.

Nota-se que o Haiti registra o maior contingente brasileiro em missões de paz de toda história. Contando com 18.422 militares e 96 policiais, a MINUSTAH é a maior contribuição brasileira em operações de paz. Aguilar relaciona o protagonismo brasileiro no Haiti à ação da diplomacia solidária brasileira, na qual o Brasil soube estimular a atuação de outros Estados em território haitiano, todos movidos pelo "dever de consciência” (AGUILAR, 2015).

Outra participação brasileira que merece destaque é a acontecida no Congo. A designação do general Santos Cruz para chefiar a MONUSCO foi feita diretamente pelo secretário-geral da ONU, Ban Ki-moon, numa tentativa de superar os desafios de desmoralização da instituição no Congo (DE SOUZA, 2015).

\footnotetext{
24 UNMEE - United Nations Mission in Ethiopia and Eritrea.

25 UNMIL - United Nations Mission in Liberia.

26 UNOCI - United Nations Operation in Côte d'Ivorie.

27 UNMIS - United Nations Mission in the Sudan.

28 UNMIT - United Nations Integrated Mission in Timor-Leste.

29 UNMIN - United Nations Mission in Nepal.

30 MONUSCO - United Nations Organization Stabilization Mission in the Democratic Republic of the Congo.

31 UNISFA - United Nations Interim Security Force for Abyei.

32 UNMISS - United Nations Mission in the Republic of South Sudan.

33 UNSMIS - United Nations Supervision Mission in Syria.

34 MINUSCA - United Nations Multidimensional Integrated Stabilization Mission in the Central African Republic.
} 
Assim como na MINUSTAH, De Souza salienta ainda que o general brasileiro também se destacou na MONUSCO, pois o mesmo conseguiu neutralizar os principais grupos armados e garantiu maior proteção aos civis na região do conflito (DE SOUZA, 2015). Pelo que foi exposto, conclui-se que o Brasil prestou importante colaboração para as OPs de $4^{\text {a }}$ Geração, tanto em termos qualitativos como quantitativos.

\section{Conclusões}

Inicia-se esta seção relembrando a evolução das missões de paz. Para tanto, será apresentada a Figura 1, que resume o processo de evolução das OPs da ONU:

Figura 1: As quatro gerações de OPs da ONU

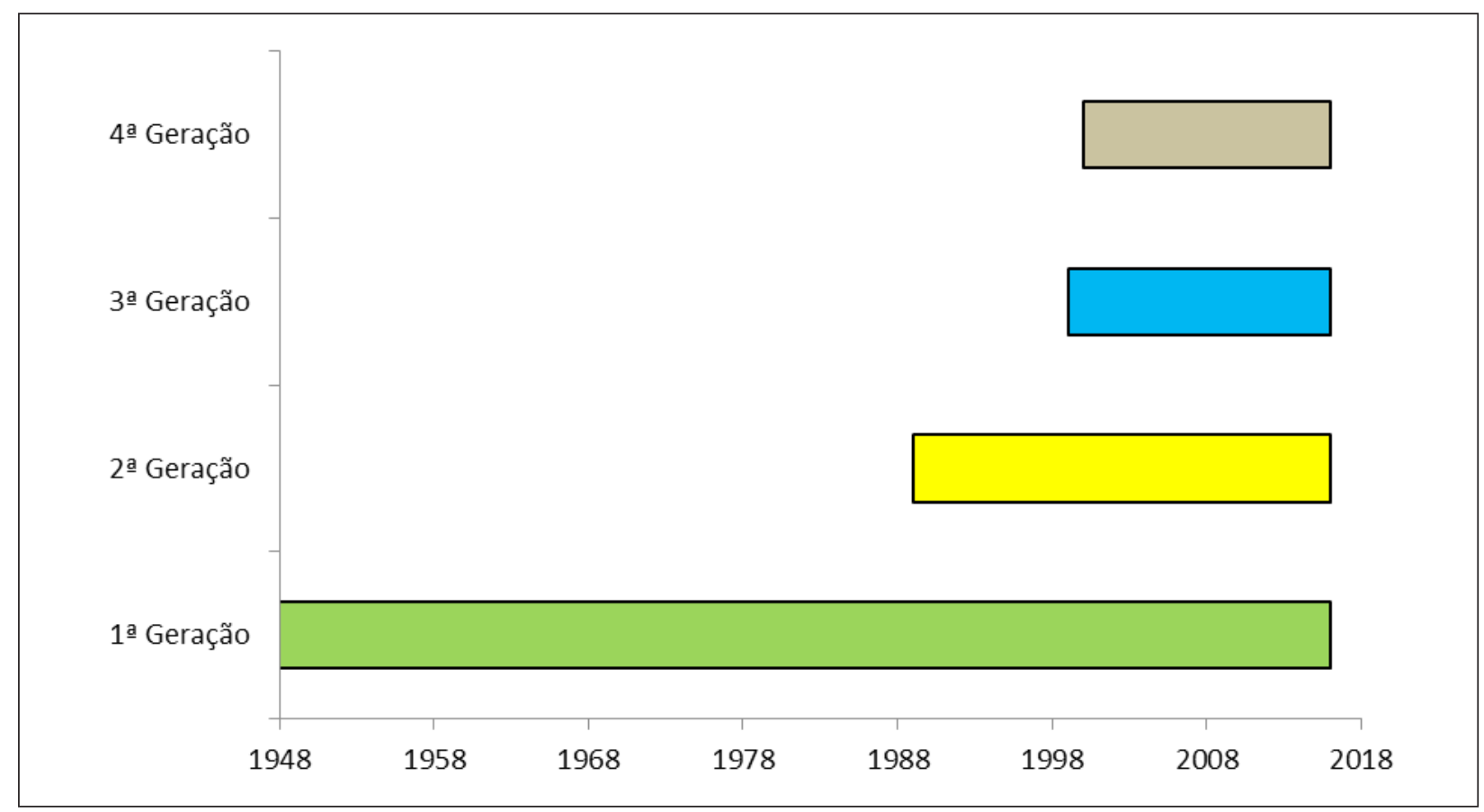

Fonte: elaboração própria, com dados do Departament of Peacekeeping Operations, 2017.

A $1^{\text {a }}$ Geração se iniciou com a UNTSO em 1948 e ainda permanece atualmente com quatro missões em curso: 1) UNTSO, 2) UNMOGIP, 3) UNFICYP e 4) UNDOF. O detalhe fica por conta da UNIFIL, que em 1978 atuava sob o escopo de $1^{\text {a }}$ Geração e, com o mandato alterado em 2007, passou a integrar a $3^{\text {a }}$ Geração das OPs.

Passando para a $2^{\text {a }}$ Geração, verifica-se que ela teve início com a UNAVEM I em 1989, registrando um total de 35 OPs em todo o seu histórico. Da mesma forma que a $1^{\text {a }}$ Geração, a $2^{\text {a }}$ Geração está presente nos dias atuais e conta com apenas uma operação de paz ocorrendo nos dias de hoje: MINURSO. 


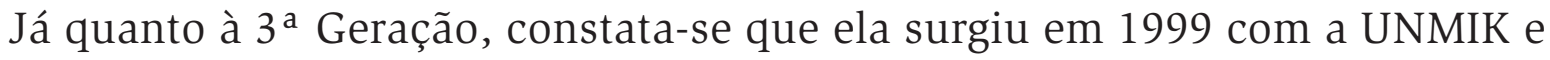
permanece nos dias atuais também, registrando seis OPs em toda a sua história. O aspecto inovador nessa geração de OPs ficou por conta da UNIFIL, missão de paz que teve início em 1978, estando enquadrada na $1^{\text {a }}$ Geração de operações de paz até 2006. Porém, a resolução ${ }^{\circ} 1701$, de 2006, do CSNU, mudou o mandato da UNIFIL, alargando o rol de atribuições e tarefas da mesma, fazendo com que essa passasse a ser caracterizada como uma missão de paz típica de $3^{\text {a }}$ Geração. Atualmente, a $3^{a}$ Geração de OPs conta com apenas duas missões em curso: 1) UNMIK e 2) UNIFIL.

A $4^{\text {a }}$ Geração se iniciou no ano de 2000 com a UNMEE e ainda está presente nos dias atuais, assinalando 14 missões em seu histórico. Das 14, seis já se encerraram e 8 continuam suas atividades: 1) UNMIL, 2) UNOCI, 3) MINUSTAH, 4) MONUSCO, 5) UNISFA, 6) UNMISS, 7) MINUSCA e 8) MINUSMA (United Nations Multidimensional Integrated Stabilization Mission in the Central African Republic).

Sendo assim, conclui-se que atualmente a ONU desenvolve 16 OPs ao redor do mundo, assim classificadas: 4 missões de $1^{a}$ Geração, 1 missão de $2^{a}$ Geração, 2 missões de $3^{a}$ Geração, 8 missões de $4^{a}$ Geração e 1 missão que pode vir a ser o início da $5^{a}$ Geração de OPs (UNAMID).

Com relação à contribuição brasileira para as OPs, ficou constatado, ao longo do trabalho, que o país se engajou nesse tema e deu significativa contribuição no decorrer dos anos. Para que se possa ter uma real compreensão disso, o gráfico 9 faz uma comparação da participação brasileira nas gerações de OPs:

\section{Gráfico 9: Participação brasileira nas gerações de OPs}

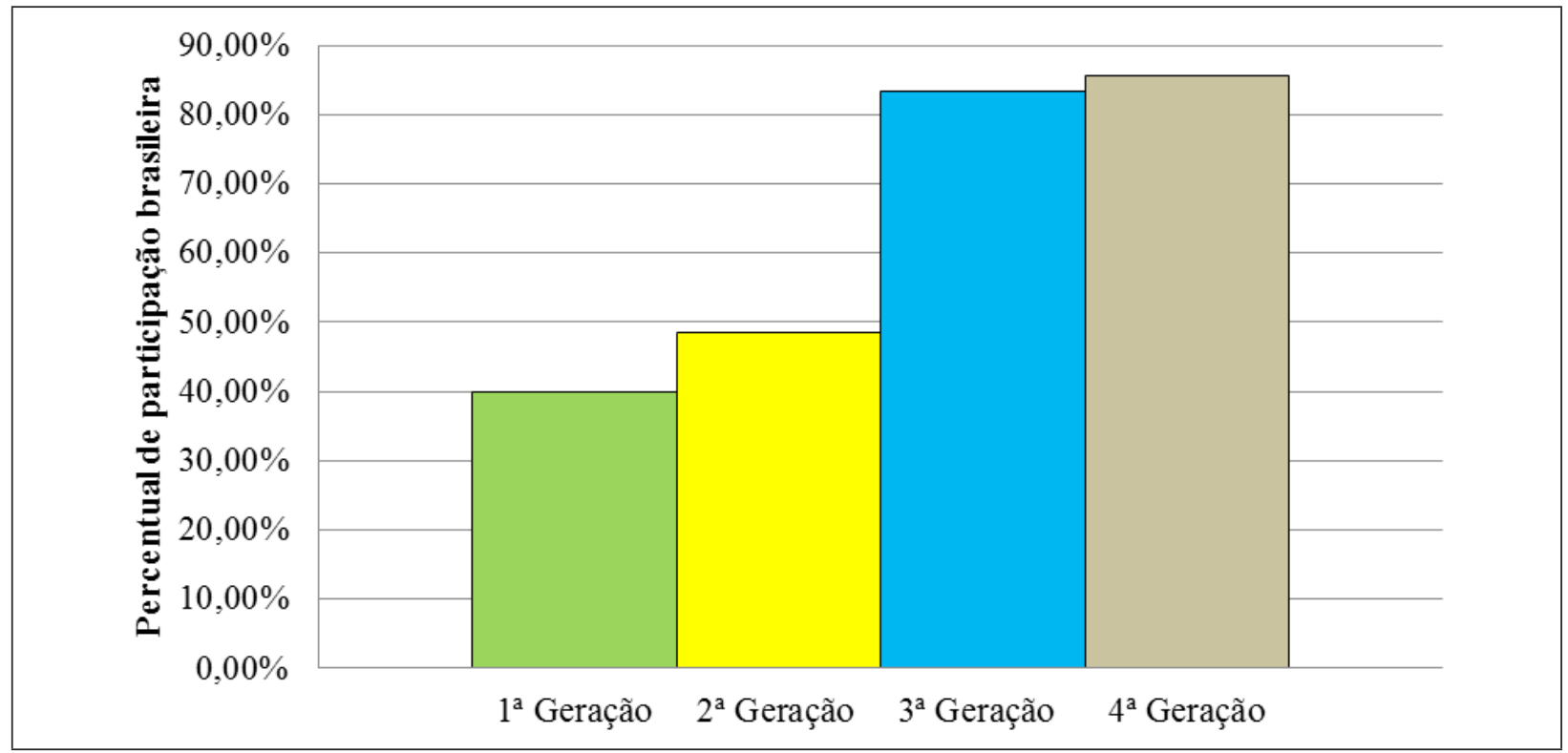

Fonte: elaboração própria, com dados do Departament of Peacekeeping Operations, 2017. 
Analisando o gráfico 9, pode-se inferir que o país aumentou gradativamente a sua participação nas missões conduzidas pela ONU, iniciando com uma atuação de $40 \%$ nas OPs de $1^{a}$ Geração, e passando para uma participação de 48,57\% nas OPs de $2^{a}$ Geração. Confirmando a trajetória ascendente da atuação brasileira em missões de paz, o país alcança 83,33\% nas OPs de $3^{a}$ Geração e chega atualmente com 85,71\% de participação nas OPs de $4^{a}$ Geração.

A trajetória ascendente da participação brasileira em OPs ao longo dos anos demonstra maior envolvimento do governo brasileiro com as missões onusianas, bem como denota um crescimento da inserção do país em assuntos de segurança e defesa no cenário internacional.

Além desses números, cabe destacar o papel do país na evolução doutrinária das missões de paz e em algumas Token Troop Contributions, citadas na sequência. No âmbito da UNEF I, o destaque fica por conta do pioneirismo brasileiro, por ter sido o primeiro país a enviar um contingente armado em OPs. A ONUMOZ representa o retorno do Brasil no envio de tropas em missões onusianas, tendo o singular destaque do general brasileiro Lélio Rodrigues da Silva, que exerceu por algum tempo o cargo de Force Comander na missão. Na UNAVEM III, sublinham-se o efetivo expressivo e o comando militar da operação de paz. Na UNTAET, ressalta-se a liderança brasileira exercida no nível político por Sérgio Vieira de Melo. Na MONUSCO, evidencia-se a liderança do contingente militar exercida pelo general Santos Cruz e o respectivo sucesso alcançado. Na UNIFIL, cumpre ressaltar o feito alcançado pelo Brasil ao se tornar o primeiro país fora da OTAN a comandar uma força-tarefa marítima em OPs. E na MINUSTAH, os destaques ficam por conta de o comando militar (Force Comander) ter permanecido exclusivamente com o Brasil em todo o período de duração e do papel multidimensional exercido pelo país em vários campos do poder.

Por fim, cabe ressaltar que a participação ativa do país em questões relativas à segurança e defesa internacional, com seus nacionais integrando diversas missões de paz e, sobretudo, com soluções brasileiras inéditas para os problemas que surgem ou surgiram no decorrer das missões, evidenciam o papel protagonista do Brasil na contribuição à evolução doutrinária das OPs sob a égide da ONU.

\section{Referências}

ABDENUR, Adriana Erthal. Rising Powers in Stormy Seas: Brazil and the UNIFIL Maritime Task Force. International Peacekeeping. Vol. 23, nº 3, 2016, p. 389-415. Disponível em: http://www.tandfonline.com/toc/finp20/23/3?nav = tocList. Acesso em: 13 abr. 2017. 
AGUILAR, Sérgio Luiz Cruz. Brasil em Missões de Paz. São Paulo: Editora Usina do Livro, 2005.

AGUILAR, Sérgio Luiz Cruz. A Participação do Brasil nas Operações de Paz: passado, presente e futuro. Brasiliana - Journal for Brazilian Studies. Vol. 3, $\mathrm{n}^{\mathrm{o}}$ 2, 2015, p. 113-141. Disponível em: http://www.ojs.statsbiblioteket.dk/index.php/bras/issue/ view/2733/showToc. Acesso em: 10 mar. 2017.

BARNETT, Michael; ZURCHER, Cristoph. The Peacebuiler's Contract: How External Statebuilding Reinforces Weak Statehood. In: PARIS, Roland; SISK, Thimothy (Orgs). The Dilemas of Statebuilding: Confronting the Contradictions of Postwar Peace Operations. Abingdton, London: Routledge, 2009, p. 23-52.

BELLAMY, Alex J. The 'Next Stage' in Peace Operations Theory? International Peacekeeping. Vol. 11, $\mathrm{n}^{\mathrm{o}}$ 1, 2004, p. 17-38. Disponível em: http://www.tandfonline.com/toc/ finp20/11/1?nav = tocList. Acesso em: 13 fev. 2017.

BELlamY, Alex J; WILliams, Paul D. The West and Contemporany Peace Operations. Journal of Peace Research. Vol. 46, n 1, 2009, p. 39-57. Disponível em: http://www. journals.sageup. com/toc/jpra/46/1. Acesso em: 11 dez. 2016.

BELLAMY, Alex J; WILLIAMS, Paul D; GRIFFIN, Stuart. Understanding Peacekeeping. $2^{\text {a }}$ edição, Malden: Polity Press, 2010.

BIGATÃo, Juliana de Paula. As Operações de Manutenção da Paz das Nações Unidas no pós-Guerra Fria: o desafio dos conflitos armados intra-estatais. In: I Encontro Nacional da Associação Brasileira de Assuntos de Defesa-ABED, 2007, São Carlos, SP. Anais Eletrônicos. Disponível em: http://www.abedef.org/conteudo/view?ID_ CONTEUDO = 74. Acesso em: 11 fev. 2017.

BOUTROS-GHALI, Boutros. An Agenda for Peace: Preventive Diplomacy, Peacemaking and Peace-keeping. (Report oh the secretary-general pursuant to the statement adopted by the summit meeting of the Security Council on 31 january 1992). 1992. Disponível em: http://www.un.org/docs/SG/agpeace.html. Acesso em: 15 mar. 2017.

BOUTROS-GHALI, Boutros. UN Peace-Keeping in a New Era: A New Chance for Peace. The World Today. Vol. 49, nº 4, 1993, p. 66-69. Disponível em: http://www.jstor.org/stab le $/ 40396494$ ? Search $=$ yes \&resultItemClick $=$ true\&searchText $=$ Boutros-Ghali\&searchU ri $=\%$ 2Faction \% 2FdoBasicSearch \% 3Fquery \% 3Dboutros-Ghali \% 26amp \% 3Bsd \% 3D \% 26amp \% 38page \% 3D2 \% 26amp \% 3Bed \% 3D \% 26amp \% 3bfilter \% 3Djid \% 253A10.230 $7 \% 252 \mathrm{Fj} 500000631 \&$ seq = 1\#page_scan_tab_contents. Acesso em: 10 fev. 2017.

BRAGA, Carlos Chagas Vianna. Uso da Força nas Operações de Paz: Solução ou Problema? In: KENKEL, Kai Michael; MORAES, Rodrigo Fracalossi de. O Brasil e as Operações de Paz em um mundo globalizado. Entre a tradição e a inovação. Brasília: IPEA, 2012. Cap. 2, p. 49-68. 
CASTELO BRANCO, Luís. As missões da ONU na África Austral: Sucessos e Fracassos. Nação

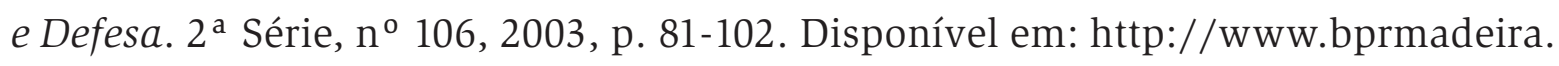
org/imagens/documentos/File/bprdigital/revistas/nacaodefesa/PP43_2003.pdf. Acesso em: 13 mar. 2017.

CEPIK, Marco Aurélio Chaves; KUELE, Giovanna Marques. Inteligência em operações de Paz da ONU (1945-2000). Revista Carta Internacional, Vol. 10, nº 1, 2015, p. 21-38. Disponível em: http://www.cartainternacional.abri.org.br/Carta/article/view/178. Acesso em: 15 abr. 2017.

CHRISTIE, Daniel J. What is Peace Psychology the Psychology of? Journal of Social Issues, Vol. 62, nº 1, 2006, p. 1-17. Disponível em: http://www.onlinelibrary.wiley. com Acesso em: 15 dez. 2016.

COLARES, Luciano da S. O Brasil e as Operações de Paz da ONU: projeção de poder pela via multilateral. In: ARTURI, Carlos S. Políticas de Defesa, Inteligência e Segurança. Porto Alegre: Editora da UFRGS, 2014, p. 147-167.

COLEMAN, Katharina P. Token Troop Contributions to United Nations Peacekeeping Operations. In: BELLAMY, Alex J; WILliAMS, Paul D. Providing Peacekeepers: The Politics, Challenges, and Future of United Nations Contributions. Oxford: Oxford University Press, 2013, p. 47-70.

CRESWELL, John W. Projeto de Pesquisa: métodos qualitativo, quantitativo e misto. $3^{\mathrm{a}}$ Edição, Porto Alegre: Artmed, 2010.

DE SOUZA, Graziene Carneiro. MONUSCO: a atuação brasileira em operações de paz robustas. Brasiliana - Journal for Brazilian Studies. Vol. 3, no 2, 2015, p. 169-196. Disponível em: http://www.ojs.statsbiblioteket.dk/index.php/bras/issue/view/2733/ show Toc. Acesso em: 10 mar. 2017.

DIEHL, Paul. Peace Operations. Malden: Polity Press, 2008.

ELLIS, Charles Howard. The origin, structure \& working of the League of nations. London: G. Allen \& Unwin, 1928.

FONTOURA, Paulo Roberto Campos Tarisse da. O Brasil e as Operações de Paz das Nações Unidas. Brasília: IRBr/FUNAG, 1999.

FONTOURA, Paulo Roberto Campos Tarisse da. O Brasil e as Operações de Manutenção da Paz das Nações Unidas. Brasília: IRBr/FUNAG, 2005.

HILLEN, Jhon. Blue Helmets: The Strategy of UN Military Operations. Dulles: Brasseys, 1998. HOWARD, Michael. Clasewitz: A Very Short Introduction. New York: Oxford University Press, 2002.

KENKEL, Kai Michael. Cinco Gerações de Operações de Paz: de "tênue linha azul" a "pintar um país de azul". Revista Brasileira de Política Internacional, Vol. 56, $\mathrm{n}^{\circ} 1$, 2013. Disponível em: http://www.scielo.br/scielo.php?script = sci_arttext\&pid = S003473292013000100007\&Ing = en\&nrm = iso\&tlng = en. Acesso em: 11 nov. 2016. 
LA MAISONNEUVE, Eric. Metamorfosis de La Violencia. Ensayos sobre La Guerra Moderna. Buenos Aires: Fundación BankBoston: Grupo Editor Latinoamericano, 1998.

MIALL, Andrew D. In defense of Facies Classifications and Models. Journal of Sedimentary Research, Vol. 69, n 1, 1999, p. 2-5. Disponível em: http://www.jsedres. Sepmonline. org/content/69/1/2.full.pdf + html? sid = 79931900-5c8a-45da-b388-dedbed828dea. Acesso em: 12 dez. 2016.

MIGON, Eduardo Xavier Ferreira Glaser. Estudos da Paz e da Guerra: síntese da contribuição de Grotius e Bobbio. Coleção Meira Mattos - Revista das Ciências Militares, v. 2, p. 53-62, 2012.

NASSER, Filipe. Pax Brasiliensis: Projeção de poder e solidariedade na estratégia diplomática de participação brasileira em Operações de paz da Organização das Nações Unidas. In: KENKEL, Kai Michael; MORAES, Rodrigo Fracalossi de. O Brasil e as Operações de Paz em um mundo globalizado. Entre a tradição e a inovação. Brasília: IPEA, 2012. Cap. 8, p. 213-242.

OSMAN, Mohamed Awad. The United Nations and Peace Enforcement: Wars, Terrorism and Democracy. Burlington: Ashgate, 2002.

PACHECO, Fabio Cordeiro; MIGON, Eduardo Xavier Ferreira Glaser. O Brasil na MINUSTAH influenciando o Brasil no Cone Sul: evidências preliminares da contribuição da diplomacia militar à inserção soberana. Coleção Meira Mattos - Revista das Ciências Militares, v. 7, p. 131-137, 2013.

PEDERSEN, Susan. The Guardians: The League of Nations and the Crisis of Empire. Oxford: OUP, 2015.

PENNA, Rodrigo Moreira. Brahimi + 10: an approaching decade of political challenges and the echoing lessons from the UN Transitional Administration of East Timor. Revista Carta Internacional, Vol. 4, nº 1, 2009, p. 46-51.

PENNA FILHO, Pio. Segurança seletiva no pós-Guerra Fria: uma análise da política e dos instrumentos de segurança das nações Unidas para os países periféricos - o caso africano. Revista Brasileira de Política Internacional, Vol. 47, n 1, 2004.

PINHEIRO DA CUNHA, Rafael Soares; MIGON, Eduardo Xavier Ferreira Glaser; VAZ, Carlos Alberto Moutinho. A Liga das Nações: considerações sobre a participação brasileira, êxitos e óbices da predecessora da Organização das Nações Unidas. Revista de Ciências Militares, v. 2, p. 317-336, 2014.

REZENDE, Lucas Pereira; AZEVEDO, César Augusto Lambert de. Sobre o Sistema de Segurança Coletiva e a Legitimidade das Operações de Paz da ONU. Revista Carta Internacional, Vol. 6, $\mathrm{n}^{\circ}$ 1, 2011, p. 23-38. Disponível em:. Acesso em: 15 abr. 2017. RICHMOND, Oliver. United Nations Peace Operations and the Dilemmas of the Peacebuiding Consensus. International Peacekeeping, Vol. 1, n ${ }^{\circ}$ 1, 2004, p. 83-101. 
RIKHYE, Indar Jit; HARBOTTLE, Michael; EGGE, Bjoern. The Thin Blue Line: International Peacekeeping and its future. New Haven: Yale University Press, 1974.

SEITENFUS, Ricardo. De Suez ao Haiti: a participação brasileira nas Operações de Paz. In: AMORIM, Celso. O Brasil e a ONU. Brasília: FUNAG, 2008. Cap 2, p. 39-58.

SILVA, Francine Rossone. A Paz Liberal nas Operações de Peacebuilding - O 'local' e os limites da crítica. 98 fl. Dissertação (Mestrado em Relações Internacionais), Pontifícia Universidade Católica do Rio de Janeiro, Rio de Janeiro, 2012.

UNITED NATIONS. An Agenda for Peace: preventive diplomacy, peacemaking peacekeeping, 17 jun 1992. Disponível em: http://www.un.org/Docs/SG/agpeace.html. Acesso em: 12 abr 2017.

UNITED NATIONS. Department of Peacekeeping Operations. United Nations Peacekeeping Operations: Principles and Guidelines, 2008. New York: Disponível em: http://www. peacekeepingbestpractices.unlb.org/pbps/pbps/library/capstone doctrine eng.pdf. Acesso em: 01 abr 2017.

UNITED NATIONS. Department of Peacekeeping Operations. United Nations Peacekeeping Operations. Disponível em: http://www.un.org/en/peacekeeping/documents/ operations/l ist.pdf. Acesso em: 01 abr 2017.

UNITED NATIONS. Department of Peacekeeping Operations. United Nations Peacekeeping Operations. Disponível em: http://www.un.org/en/peacekeeping/documents/ operations/current.shtml. Acesso em: 01 abr 2017.

UNITED NATIONS. Department of Peacekeeping Operations. United Nations Peacekeeping Operations. Disponível em: http://www.un.org/en/peacekeeping/resources/statistics/ contributors.shtml. Acesso em: 01 abr 2017.

UNITED NATIONS. Report of the Panel on United Nations Peace Operations. Disponível em: < http://www.un.org/peace/reports/peace_operations > Acesso em: 25 mar 2017.

WILLIAMS, Paul. Lições aprendidas com as operações de paz em África. Centro de Estudos Estratégicos de África. n 3, 2010. Disponível em: http://www.africacenter. org. Acesso em: 12 fev. 2017. 


\title{
O histórico da segurança humana e o (des)encontro das agendas de desenvolvimento \\ e segurança
}

\section{The history of human security and the (mis) match of the development and security agendas}

\author{
DOI: $10.21530 /$ ci.v12n3.2017.676
}

Raquel Maria de Almeida Rocha ${ }^{1}$

\section{Resumo}

O presente artigo busca reconstruir a trajetória da segurança humana no Relatório de Desenvolvimento Humano (RDH) do Programa de Desenvolvimento das Nações Unidas (PNUD) de 1994 e no Relatório da Comissão Internacional sobre Intervenção e Soberania Estatal (CIISE) de 2001. Pretendemos com isso demonstrar que existe pouco diálogo e contribuição do primeiro com o segundo. Para tanto, traçaremos o histórico do conceito de segurança humana, focando nos relatórios mencionados, a fim de evidenciar a forma pela qual as agendas de desenvolvimento e de segurança possuem baixo nível de debate, diálogo e contribuição entre si. Nossa metodologia inclui revisão bibliográfica e entrevistas, além de análise de documentos e relatórios do sistema ONU e do CIISE para construção de process tracing.

Palavras-chave: Segurança humana; Desenvolvimento; Relatório de Desenvolvimento Humano (RDH); Relatório da Comissão Internacional sobre Intervenção e Soberania Estatal (CIISE).

\begin{abstract}
The article seeks to reconstruct the trajectory of human security on the Human Development Report (HDR) from the United Nations Development Program (UNDP) of 1994 and on the International Commission on Intervention and State Sovereignty (ICISS) Report of 2001. We intent to demonstrate that there is little dialogue and contribution between the two. For that, we trace the history of the concept of human security, focusing on the mentioned reports,

1 Departamento de Relações Internacionais da Escola Superior de Propaganda e Marketing, São Paulo/SP, Brasil. E-mail: raquel.maria.rocha@espm.br

Artigo submetido em 27/05/2017 e aprovado em 03/11/2017.
\end{abstract}


seeking to evidence the way by which the agendas of development and security have a low level of debate, dialogue and contribution amongst them. Out methodology includes literature review, interviews and analyses of documents and reports of the UN system and the ICISS for process tracing.

Keywords: Human security; Development; Human Development Report; International Commission on Intervention and State Sovereignty (ICISS).

\section{Introdução}

A segurança humana, mesmo que controversa, foi incorporada por Estados, organizações internacionais, regionais e não governamentais. O debate em relação a sua relevância, significado e definição é constante, mas já está incorporado nos círculos acadêmicos e políticos ${ }^{2}$. Os valores e ideais embutidos nele estão presentes na carta constitutiva das Nações Unidas de 1945 e nos demais instrumentos do direito internacional que se preocupam com uma concepção da segurança focada nas pessoas 3 . No entanto, a expressão “segurança humana” surge apenas no início dos anos de 1990 como um dispositivo intelectual e instrumento de advocacy nas relações internacionais, unindo preocupações sobre proteção, direitos e bem-estar individual. A segurança humana engloba a ideia de que a segurança vai além do simples conceito da garantia da segurança física, no sentido tradicional, ao incorporar que as pessoas também devem ter garantida uma "segurança social”. Além de buscar identificar ameaças, evitá-las e mitigar seus efeitos sempre que possível, como as demais concepções de segurança.

Tadjbakhsh e Chenoy (2007, p. 27) fazem uma divisão cronológica de três grandes estágios para a construção do conceito de segurança humana4. Primeiramente, o termo foi utilizado no Relatório de Desenvolvimento Humano (RDH) do Programa das Nações Unidas para o Desenvolvimento (PNUD) ${ }^{5}$, no

2 Ver, e.g, PARIS, 2001; MCRAE, HUBERT, 2001; HAMPSON et al, 2002; BUZAN, 2004; MACFARLANE, KHONG, 2006; OWEN, 2008; KRAUSE, 2014; MARTIN; OWEN, 2015.

3 Como por exemplo a Declaração Universal de Direitos Humanos de 1948 e as convenções associadas de 1966, Convenção para a Prevenção e a Repressão do Crime de Genocídio de 1948, Convenção relativa ao Estatuto do Refugiado de 1951, Convenção sobre a Eliminação de todas as formas de Discriminação contra a Mulher de 1979, Convenção sobre os Direitos da Criança de 1989, dentre outros.

4 Martin e Owen (2010) falam em duas gerações, pois unificam os dois primeiros "estágios”.

5 Embora a expressão seja mencionada anteriormente por Boutros-Ghali no relatório Uma Agenda para a Paz, em 1992, e posteriormente seja citada cinco vezes no relatório de 1993 para expressar o "desenvolvimento centrado nas pessoas”, é somente no RDH de 1994 que ela vai ser formalmente definida. 
qual a segurança humana foi descrita como liberdade do medo (freedom from fear) e liberdade de necessidades (freedom from want). A definição conta com a contribuição de Estados-membros, órgãos e agências internas, e também de figuras políticas e acadêmicas na liderança e modelagem da discussão. O relatório tentou aproveitar as reflexões do pós-Guerra Fria, juntamente com novos temas e atores que emergiam do período. É necessário lembrar que, nesse período, os temas de segurança eram restritos e enquadrados em um debate Leste-Oeste. Enquanto a questão do desenvolvimento era Norte-Sul.

Nef (1999) ressalta que, nesse período, a segurança e o desenvolvimento não mais eram vistos através de perspectivas de soma zero, mas sim como ganho e perda quando colocados em conjunto, principalmente quando pensamos nas ameaças transfronteiriças como pobreza ou epidemias, por exemplo. Logo, altos níveis de segurança levam ao desenvolvimento econômico, o que promove segurança e, por conseguinte, altos níveis de desenvolvimento, o que gera segurança e promove desenvolvimento, e assim em diante. A segurança humana é fundamentada no desenvolvimento humano. Porém, o RDH foi recebido com ceticismo pelo G77, pois os Estados temiam que o conceito levaria a violações da soberania estatal, o que fez com que a segurança humana não fosse adotada durante a Cúpula Mundial para o Desenvolvimento Social de Copenhague em 1995.

Mesmo assim, a Rede de Segurança Humana (RSH) formada por uma coalizão de 13 países $^{6}$, liderados pelo Canadá, uniu esforços para campanhas de advocacy que levaram à assinatura da Convenção de Ottawa em 1997 e do Estatuto de Roma em 1998. A RSH se organiza em torno da temática da Convenção de Ottawa que se formaliza em 1999. Além disso, a RSH liderou encontros ministeriais que discutiam questões como direitos humanos, prevenção de conflitos e HIV/AIDS. Em 2000, é criado - por iniciativa japonesa - o Fundo das Nações Unidas para a Segurança Humana (FNUSH), a fim de concretizar e operacionalizar o conceito, ao financiar projetos relacionados à construção da paz, à restauração pós-conflito, às abordagens da pobreza crônica, à redução de risco de desastre, ao tráfico humano e à segurança alimentar, buscando traduzi-lo em atividades operacionais que proporcionem benefícios sustentáveis às pessoas e comunidades que tenham sua sobrevivência, dignidade e sustento ameaçados; além de empoderar os indivíduos

6 Áustria, Canadá, Chile, Costa Rica, Grécia, Irlanda, Jordânia, Mali, Holanda, Noruega, Suíça, Eslovênia e Tailândia, além da África do Sul como observador. O Japão foi convidado para participar desde o início da rede, mas declinou em duas ocasiões devido à ênfase na intervenção humanitária e à reserva fundamental japonesa em usar a força sem a autorização do Conselho de Segurança da ONU (TAKASU, 2015: p. 245). 
para aumentar sua resiliência. O primeiro estágio é um período de aplicação prática da segurança humana.

O segundo estágio ocorreu entre 2001 e 2003. O conceito é recuperado no debate sobre a "Responsabilidade de Proteger” dentro do Relatório da Comissão Internacional sobre Intervenção e Soberania Estatal (CIISE), liderada e patrocinada pelo governo canadense, e também nas discussões sobre a "responsabilidade por desenvolvimento" iniciadas pelo governo japonês na Comissão de Segurança Humana (CSH). Aqui, o conceito aparece embebido em preocupações da agenda estatal e da agenda da segurança tradicional, principalmente da leitura realizada pelo governo canadense do que seria a segurança humana - focada largamente na segurança física das pessoas. O CIISE conta com a participação de acadêmicos e Estados patrocinadores. Já o terceiro estágio vai dos anos de 2004 a 2005, quando a segurança humana passa a ser o tema de agendas de reforma no sistema das Nações Unidas e em organismos regionais como a União Europeia.

Grande parte da literatura de relações internacionais situa segurança humana no debate de ampliação dos estudos de segurança internacional. Contudo, sua origem é decorrente de debates dos economistas desenvolvimentistas ${ }^{7}$ sobre como humanizar a economia e lidar com as novas ameaças ao indivíduo, especificamente no RDH do PNUD de 1994. A princípio, a ideia da segurança humana encontrou resistência por parte de acadêmicos de segurança e de alguns Estados e foi somente em 2001, no Relatório do CIISE, que a primeira “contraproposta” ou redefinição da segurança humana ocorreu, na forma da responsabilidade de proteger, reforçando ainda mais os receios sobre violações da soberania estatal. Enquanto na dimensão do desenvolvimento temos o RDH como marco inicial para definir a segurança humana, é possível argumentar que o marco inicial desse debate no âmbito da agenda de segurança é o CIISE. Até a aprovação do relatório que propõe o conceito de Responsabilidade de Proteger, existiam somente algumas

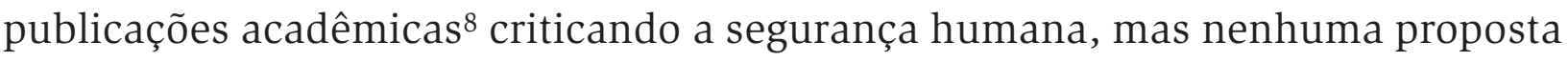
ou aplicação concreta da abordagem.

Este artigo pretende demonstrar que há pouco diálogo entre o RDH do PNUD de 1994 e o CIISE de 2001 no que tange a construção da abordagem da segurança humana, o que gera impactos tanto em termos de reflexão quanto na aplicabilidade

7 Economistas desenvolvimentistas são aqueles que não se contentam em definir desenvolvimento em termos de crescimento e medições de agregação nacional, e passam a focar na mensuração do bem-estar humano e nas formas através das quais se afeririam melhoras de bem-estar na vida das pessoas.

8 Ver e.g. (MCRAE, HUBERT, 2001). 
do conceito. Para tanto, traçaremos o histórico do conceito de segurança humana, buscando evidenciar o nível baixo de debate, diálogo e contribuição entre as agendas de desenvolvimento e de segurança. Nossa metodologia inclui revisão bibliográfica e entrevistas com funcionários do PNUD, além da análise de documentos e relatórios do sistema ONU e do CIISE para elaboração de process tracing 9 . Vale notar que o artigo não está baseado em uma hipótese, utilizamos como recurso a hermenêutica ao invés do positivismo cientifico. A intenção aqui não é confirmar ou falsear uma suposição, mas sim reconstruir a trajetória de uma ideia à fim de lançar luz em uma intersecção pouco explorada, que gera consequências para os rumos tanto da agenda de segurança quanto da de desenvolvimento. Para isso, este trabalho está estruturado em quatro partes: introdução, apresentação da construção do Relatório do PNUD, apresentação da construção do Relatório do CIISE e conclusões.

\section{A segurança humana nos anos de 1990}

Conforme apontado na introdução, a segurança humana é definida de forma contundente no RDH de 1994 do PNUD. O PNUD é um programa do sistema ONU, criado em 1965 para realizar atividades em países em desenvolvimento por meio da cooperação técnica multilateral e nasce da fusão do Programa Ampliado de Assistência Técnica das Nações Unidas de 1949 e do Fundo Especial das Nações Unidas de 1959. Suas atividades buscam o desenvolvimento tanto nos setores econômicos quanto nos sociais e desenvolvem projetos com os setores público e privado ao incentivar uma gestão responsável em todos os níveis da sociedade, buscando conquistar o desenvolvimento humano sustentável (UNIC, 2009).

Alocado no PNUD, está o Escritório do Relatório do Desenvolvimento Humano (ERDH), sediado em Nova Iorque. Possui a missão de avançar o desenvolvimento humano e o objetivo de contribuir a favor da expansão das oportunidades, escolhas e liberdades (UNDP, 2015). O escritório busca promover novas ideias, mudanças práticas de política e desafiar de forma construtiva políticas que dificultem o desenvolvimento humano. Para isso, o Escritório publica, desde 1990 e 1992 respectivamente, o Relatório do Desenvolvimento Humano e os Relatórios Nacionais

9 Entendemos process tracing como uma ferramenta qualitativa de análise interna de um caso que visa explanar um fenômeno social ao buscar identificar padrões e sequências através da reconstrução do processo de construção do fenômeno. 
e Regionais do Desenvolvimento Humano. O primeiro monitora o "progresso da humanidade” através de classificações de países, de acordo com o Índice de Desenvolvimento Humano (IDH), dentre outros (UL HAQ, 1995), enquanto o segundo é uma "caixa de ferramentas" (UNDP, 2015) que propõe ações passo a passo para que um país conquiste o desenvolvimento humano. Como seu foco é na pesquisa e publicação, possui autonomia, conforme explanaremos abaixo.

O primeiro RDH, lançado em 24 de maio de 1990, explora a relação entre crescimento econômico e desenvolvimento humano e tem o foco de aumentar as opções disponíveis para as pessoas ao invés de focar somente em quanto a nação está produzindo, segundo Ul Haq (1995). O texto estabelece que as pessoas são a real riqueza de uma nação, premissa que passa a guiar os demais relatórios. A parceria de Ul Haq com Sem fez com que o conceito do desenvolvimento humano ganhasse maior robustez teórica ${ }^{10}$, além de contar com diversidade de dados empíricos e uma abordagem inovadora para medir desenvolvimento. Dessa forma, o RDH acarretou largo impacto no pensamento sobre desenvolvimento ao redor do globo.

O desenvolvimento humano, para Amartya Sen (1999), pode ser visto como um processo de expansão das reais liberdades que os indivíduos gozam e afirma que focar nas liberdades do ser humano contrasta com visões mais restritas do desenvolvimento, como identificar desenvolvimento através desenvolvimento através da mensuração do crescimento do produto interno bruto (PIB) ou com aumento de rendas pessoais, industrialização, avanço tecnológico, industrialização ou modernização social. Aumentos de renda ou PIB podem ser meios significativos para que indivíduos expandam as suas liberdades enquanto membros da sociedade, mas existem outros determinantes destas liberdades como arranjos econômicos — tais como acesso à educação e saúde - bem como direitos políticos e civis por exemplo, ter a liberdade para participar em discussões públicas. Da mesma forma, o progresso tecnológico, industrial ou modernização social podem contribuir substancialmente na expansão da liberdade humana, mas estes também podem sofrer influências. Ver desenvolvimento em termos de expansão de liberdades substantivas direciona atenção para os fins que fazem o desenvolvimento importante, ao invés de alguns meios terem meramente um papel proeminente no processo (SEN, 1999).

10 Sen redigiu em co-autoria com Sudhir Anand o Human Development Index: Methodology and Measurement, em 1992, como background paper e, em 1993,o texto entra como parte do RDH (UL HAQ 1995). 
Em termos institucionais, o PNUD, dentre outras organizações, exerceu um papel significativo neste processo de reconceptualização, especialmente no desenvolvimento de medidas de desenvolvimento humano e taxa de desempenho, encorajando recipientes de assistência de desenvolvimento a focar na distribuição de renda, qualidade de vida e conquista de necessidades básicas, o que também possuiu um efeito de transbordo uma vez que influencia políticas e práticas de agências e seus maiores doadores. O RDH seria, então, o produto anual de um esforço coletivo do ERDH, sob a orientação do diretor e através de pesquisa, dados estatísticos, comunicação, equipe de publicação e um time de apoio responsável pelo Relatório Nacional e Regional. A pesquisa e redação do mesmo é então um trabalho conjunto do time administrativo do ERDH, do grupo de conselheiros eminentes e do diretor do ERDH, além de contar com contribuições de especialistas externos (UNDP, 2011), todos identificados no início de cada um dos relatórios na seção dos agradecimentos.

Os background papers são documentos produzidos pelos assessores do ERDH, com cerca de 5 a 10 páginas, contendo uma primeira proposta do que seria um dos capítulos do RDH (JAHAN, 2016), através de argumentos baseados em pesquisa, evidências e dados que devem respeitar um padrão de qualidade em termos de comparações globais ou regionais e da cobertura em termos de países, população global coberta etc. Já o Painel de Assessores Externos é composto por especialistas e pioneiros em desenvolvimento humano, buscando equilíbrio geográfico e de gênero, indicados pela diretoria do ERDH para o administrador do PNUD, que detém a última palavra (MUKHOPADHYAY, 2016).

A estrutura tem sido razoavelmente a mesma ao longo dos anos, variando em tamanho e composição, de acordo com as necessidades para a temática e os recursos disponíveis no escritório para determinado ano. Tal multidisciplinaridade permite que o time tenha diferentes compreensões sobre prioridades de políticas específicas. Assim, seu objetivo, de forma mais ampla, é desenvolver análises e opções de posições de políticas que sejam mais consistentes com a abordagem das capacidades do desenvolvimento humano. Todos os RDH tentam realizar inovações/ recomendações analíticas, empíricas e de políticas que possam enriquecer o debate para além do foco do tema anual.

Jahan (2016) ainda afirma que existe um processo de consultas com diversos stakeholders como o Conselho Executivo, o Painel de Assessores, acadêmicos e pesquisadores, bem como outras agências do sistema ONU, mas, que mesmo ao realizar tais consultas com grupos diversos, existe independência editorial - 
garantida pela Assembleia-Geral ${ }^{11}$ e pelo Conselho Executivo do PNUD. Dessa forma, pode ou não serem incluídas sugestões colocadas por tais representações, pois não é necessária autorização para a publicação do conteúdo e nenhuma das partes consultadas participa do processo de redação do relatório (JAHAN, 2016). Assim, as análises e recomendações de políticas estabelecidas nos RDHs não necessariamente refletem as visões oficiais do PNUD, de seu Conselho Executivo ou do sistema ONU como um todo.

É relevante compreender o processo de elaboração do RDH para que fique clara a origem desse discurso inicial da segurança humana, pois toda discussão subsequente sobre o termo tem tal ponto de origem. E também porque a literatura das relações internacionais acaba por fazer uma leitura de que essa foi uma contribuição praticamente exclusiva do sistema ONU, ao afirmar que a organização serviu de incubadora para aspectos chave do pensamento da segurança humana (MACFARLANE; KHONG, 2006; MARTIN; OWEN, 2010).

Contudo, é possível afirmar que a variável determinante para a definição inicial do termo foi a parceria com acadêmicos - há um esforço de pesquisa acadêmica, de investigação e compilação de dados, revisão de pares e propostas de políticas para os Estados-membros. Isso fica evidenciado na liberdade editorial que é concedida ao Relatório, na composição do corpo de funcionários e autonomia do ERDH com relação à estrutura do PNUD, órgão que o abriga (além do sistema como um todo), desde os primórdios da publicação.

Por mais que o sistema ONU possa ser considerado um ambiente propício para o surgimento de novos termos, onde atores diversos se unem para buscar soluções para ameaças à paz e segurança internacional, o Relatório é uma atividade majoritariamente analítica e não possui envolvimento algum por parte dos Estadosmembros, ao menos em nível institucional. O atual diretor do ERDH, Selim Jaham (2016), afirma que os temas são definidos pela equipe e somente depois ocorrem as consultas entre as agências do próprio sistema e Estados-membros na busca de opiniões e sugestões.

O Relatório de 1994 é o primeiro onde a segurança humana é definida, conforme previamente citado, e é o que populariza a abordagem, pois essa

11 Sua autonomia editorial é garantida através de uma resolução especial da AGNU — A/RES/57/264 —, que reconhece o RDH como um exercício intelectual independente e importante ferramenta em trazer atenção sobre desenvolvimento humano ao redor do globo (UN, 2003). Ademais, Haq ressalta em seu livro Reflections on Human Development que a independência intelectual e integridade profissional inicial dos relatórios somente ocorreram porque William H. Draper III, diretor Administrativo do PNUD (1986-93) acreditou no projeto e resistiu à pressão internacional(UL HAQ 1995). 
segue sendo a definição mais citada (PARIS, 2001; MACFARLANE; KHONG, 2006; NEWMAN, 2010). Ele possui 226 páginas e foi realizado com o objetivo de influenciar o diálogo de cooperação para o desenvolvimento entre Estados-membros e agências e programas do sistema ONU. Busca tratar do que chama de "crise silenciosa”, uma crise de subdesenvolvimento, pobreza, pressão e degradação do meio ambiente (UNDP, 1994: p. iii). Além disso, propôs uma agenda para a Cúpula Mundial para Desenvolvimento Social, que ocorreu em Copenhague em 1995, reconhecendo que a solução para tal crise deveria partir de um significativo investimento no desenvolvimento humano e que os papeis das Nações Unidas e do próprio PNUD deveriam ser fortalecidos nesse processo, ao invés de continuar focando em políticas intervencionistas e auxílio emergencial.

Levando isso em consideração, fica mais evidente que o RDH de 1994 reflete não apenas uma alteração do que é segurança, mas também da compreensão do que é desenvolvimento dentro deste primeiro estágio, como classificam Tadjbakhsh e Chenoy (2007). O Relatório possuía como tema central o desenvolvimento humano sustentável, ao afirmar que esse é o desenvolvimento que prioriza a população pobre ao ampliar suas escolhas e oportunidades enquanto empodera pessoas. A segurança humana foi vista como parte da busca pelo desenvolvimento humano, uma vez que o desenvolvimento centrado nas pessoas é necessário para conquistar a paz, direitos humanos, proteção ambiental e integração social, estabelecendo que “[s]em paz, pode não existir desenvolvimento. Mas sem desenvolvimento, a paz é ameaçada12" (UNDP, 1994: p. iii). Além disso, propunha descobertas de sinais de alerta precoce que poderiam ser utilizados como diplomacia preventiva - essa foi uma alteração solicitada pelo Secretário-Geral Kofi Annan, quando abordou as causas de conflitos e promoção da paz durável - e em prol do desenvolvimento para evitar uma eventual crise.

Dessa forma, a agenda de desenvolvimento propôs tal abordagem para as novas ameaças que surgiam com a nova ordem internacional; dentro de uma lógica das Nações Unidas, isso era pensar em diplomacia preventiva como forma de atuação nos anos 1990. Pode-se notar, no Relatório, que diversos analistas haviam tentado estabelecer definições rigorosas para a segurança humana, mas, assim como outros conceitos fundamentais, essa é mais facilmente identificada pela ausência do que pela sua presença e a maior parte das pessoas compreende segurança de forma instintiva, ou seja, um sentimento inerente. Existe, inclusive,

12 “Without peace, there may be no development. But without development, peace is threatened." (UNDP, 1994: p. iii) 
no RDH, uma seção dedicada para "Segurança humana - como as pessoas a veem $^{13}$ ”, onde são incorporadas citações de indivíduos de diversas nacionalidades definindo segurança, e.g, aluna da quarta série de Gana: “Eu me sentirei segura quando eu souber que eu posso andar nas ruas à noite sem ser estuprada14" (UNDP, 1994: p. 22). O Relatório afirma que:

[s] egurança humana deve ter dois aspectos principais. Isso quer dizer, primeiro, segurança de ameaças crônicas como fome, doença e repressão. E segundo, quer dizer proteção de distúrbios abruptos e danosos da vida diária - seja na casa, no emprego ou em comunidades. Tais ameaças podem existir em todos os níveis de renda e desenvolvimento. ${ }^{15}$ (UNDP, 1994: p. 23)

Ademais, devem sempre existir dois componentes: (i) liberdade de ameaças que prejudicam direitos, segurança à vida das pessoas, estabelecendo a necessidade de ser livre do medo da violência física, do indivíduo ser livre do medo (freedom from fear), de crimes e guerras e (ii) liberdade de necessidades (freedom from want), de acesso à saúde, de acesso econômico e à ambiente estável.

Além disso, o Relatório define sete aspectos como basilares para a abordagem: (1) segurança econômica - renda oriunda de emprego ou assistência social que garanta sobrevivência da pessoa e sua família; (2) segurança alimentar acesso (econômico e físico) a comida básica capaz de garantir o consumo de nutrientes necessário; (3) direito à saúde - ambiente sem propagação de doenças crônicas e com disponibilidade de cuidados médicos; (4) segurança ambiental - ausência de ameaças ambientais e garantias de água potável, ar fresco etc.; (5) segurança pessoal - ausência de violência e ameaças físicas, sejam elas política, de guerra, étnica, de rua, doméstica ou de gênero, abuso de menor ou suicídio; (6) segurança comunitária - segurança dada à pessoa por pertencer a um grupo, e.g., comunidade ou grupo étnico; e (7) segurança política - gozo de direitos humanos básicos, e.g., direito de ir e vir(UNDP 1994).

Por conseguinte, é possível argumentar que existe um esforço pelas “(...) agências da ONU em 'humanizar' o desenvolvimento ao encorajar a mudança dos

13 "Human security - as people see it" (UNDP, 1994: p. 22)

14 "I shall feel secure when 1 know that I can walk the streets at night without being raped." (UNDP, 1994: p. 22)

15 "Human security can be said to have two main aspects. It means, first, safety from such chronic threats as hunger, disease and repression. And second, it means protection from sudden and hurtful disruptions in the patterns of daily life-whether in homes, in jobs or in communities. Such threats can exist at all levels of national income and development." (UNDP, 1994: p. 23) 
agregados nacionais para o foco nas necessidades individuais e empoderamento 16 " (MACFARLANE, KHONG, 2006: p. 139), um processo que ocorre desde a incorporação do conceito de desenvolvimento de Amartya Sen e se acentua a partir do momento em que a abordagem de segurança humana emergiu da agenda do desenvolvimento do PNUD. Tudo isso ocorre em um ambiente pós-Guerra Fria e com o declínio de conflitos entre Estados, no qual florescia o debate sobre a relação entre segurança e novos temas, como privação econômica e qualidade de vida como fontes de instabilidade. Possibilitando a compreensão de que uma ameaça a um indivíduo ou grupo pode ser vista como uma ameaça à segurança internacional.

Cabe destacar que a "concorrência econômica-tecnológica, os desequilíbrios ambientais, a explosão populacional, as migrações internacionais e o narcotráfico" (VILLA, 1999: p. 99) também ocupavam espaço na agenda de segurança no pósGuerra Fria. Outro aspecto fundamental do debate dizia respeito ao tema da saúde, sobretudo em virtude da epidemia de HIV/AIDS na época - a emergência de uma epidemia local pode resultar em um contágio global, através dos sistemas de transportes modernos. Assim, é possível notar que a desterritorialização de transações econômicas e culturais passaram a impactar na autonomia dos Estados e da sociedade internacional, evidenciando a necessidade de atuar de forma cooperativa, conforme ressalta o RDH.

O "empoderamento" era a inclusão mais recente no que se compreendia como desenvolvimento humano; tal inclusão foi feita no RDH de 1993 e prossegue até hoje, corroborando que o empoderamento é essencial dentro do Estado e em mercados não somente devido à melhora da participação popular, mas porque desenvolvimento também quer dizer ajudar e amparar as pessoas para que elas sejam capazes de controlar as suas vidas. Isso foi estendido para a realidade da segurança, como já se afirmava no Relatório do PNUD de 1993:

[o] conceito de segurança deve mudar - de um foco exclusivo em segurança nacional para maior ênfase à segurança das pessoas, da segurança através dos armamentos para segurança para desenvolvimento humano, de segurança territorial para comida, emprego, e segurança ambiental. ${ }^{17}$ (UNDP, 1993: p. 1-2)

16 "UN agencies in "humanizing" development by encouraging the shift from national aggregates to a focus on individual needs and empowerment.” (MACFARLANE, KHONG, 2006: p. 139)

17 "The concept of security must change from an exclusive stress on national security to a much greater stress on people's security, from security through armaments to security through human development, from territorial security to food, employment and environmental security." (UNDP, 1993: p. 1-2) 
O impacto do Relatório de 1994 para o debate sobre desenvolvimento e sobre segurança deve-se ao fato de que, pela primeira vez, segurança foi explicitamente ligada a políticas de desenvolvimento dentro do sistema ONU. Ele recomenda uma transição conceitual profunda de distanciamento da segurança militar ou nuclear e de aproximação entre os dois temas, especialmente ao passo que certos conflitos intraestatais estavam crescendo e que suas origens eram largamente baseadas em disparidades econômicas e privações.

Como qualquer outra concepção de segurança, a segurança humana trata da capacidade de identificar ameaças, de evitá-las sempre que possível e mitigar seus efeitos quando ocorrem. No entanto, seu sentido específico engloba a ideia de que a segurança vai além do mero conceito de segurança física no sentido tradicional, e incorpora a perspectiva de que a vida das pessoas deve ser garantida através de "segurança social" contra distúrbios repentinos (TADJBAKHSH, 2005). Neste mesmo sentido, a teórica Mary Kaldor (2007) define então segurança humana como a defesa dos indivíduos e de suas comunidades ao invés de segurança dos Estados e dos princípios que esclarecem as diferenças relativas às abordagens convencionais da segurança e do desenvolvimento, ressaltando então a primazia dos direitos humanos, autoridade política legítima, multilateralismo e abordagem bottom up e regional. Deve-se ressaltar, entretanto, que não existe uma definição única para segurança humana ${ }^{18}$ e o termo vem sendo referenciado na academia das relações internacionais e de desenvolvimento como ponto de partida de análise, visão de mundo, agenda política ou estrutura política.

De tal modo, é possível argumentar que a ideia de segurança humana é composta de duas partes entendidas como indissociáveis: desenvolvimento e proteção. A primeira reconhece a relevância do desenvolvimento humano e de fontes econômicas para evitar conflitos enquanto a segunda reconhece proteção física como prioridade. Prover segurança humana se traduz em iniciativas para construir um ambiente seguro para o desenvolvimento humano em uma relação de mútua influência. Existe uma aparente disputa entre campos da comunidade da segurança humana que argumentam por ou "primeiro desenvolvimento" ou "primeiro segurança”; no entanto, na perspectiva da segurança humana, as duas posições não são mutuamente exclusivas, segundo MacFarlane e Khong (2006, p. 201).

18 Para maiores discussões sobre a definição da segurança humana, ver, e.g. Security Dialogue. What is Human Security. vol. 35, no. 3, September, 2004. Special Section. Edição especial com a pergunta "O que é segurança humana?”. Para marcar os dez anos da segurança humana, reuniu os 21 acadêmicos que mais haviam expressado sua opinião sobre o termo, que até hoje facilita a localização dos teóricos no debate entre amplo e restrito. 
É necessária cautela para distinguir de forma adequada segurança humana, desenvolvimento humano e direitos humanos, uma vez que todos estão entrelaçados na preocupação direta com a melhoria da natureza das vidas humanas, mas os conceitos possuem distinções entre si. É possível observar que a ideia de segurança humana suplementa a perspectiva expansionista de desenvolvimento humano, que se preocupa diretamente com as pessoas, suas capacidades e oportunidades ao invés de somente com a forma pela qual as mesmas contribuem para o crescimento econômico do Estado.

Deve-se atentar ao que muitas vezes são chamados de "riscos descendentes", por Sen et al.(2003), ou seja, as inseguranças que ameaçam a sobrevivência humana ou sua segurança do cotidiano. São aqueles fatores que colocam em perigo a dignidade natural dos indivíduos, expõem o ser humano à incerteza de doenças e pestes ou sujeitam pessoas vulneráveis a penúrias abruptas relacionadas a quedas econômicas que demandam atenção especial aos perigos da privação repentina de segurança humana - é necessária, então, não somente a proteção em relação a tais perigos, mas também o empoderamento das pessoas para que estas consigam lidar com e, quando possível, superar tais ameaças.

Não existe contradição entre o foco da segurança humana e o objeto da abordagem do desenvolvimento humano, mas a ênfase e as prioridades são distintas. A segurança humana não se preocupa em compreender as capacidades e oportunidades do indivíduo, mas sim se eles estão livres de ameaças e se sua vida está sendo garantida com dignidade, por consequência. O desenvolvimento humano busca o crescimento com igualdade, mas, ao mesmo tempo, não se preocupa com aquele trabalhador deslocado ou o desempregado perene e o que ele pode gerar em termos de ameaças à segurança dele mesmo e da sociedade em que convive, aspecto com o qual a segurança humana se preocupa. Até hoje, o paradigma mais importante para o PNUD é o de desenvolvimento humano.

Tal relação complementar com os direitos humanos é ainda mais nítida. Conforme Sen et al (2003) argumenta, o último conceito é invocado frequentemente em debates políticos contemporâneos e possui uma atratividade profunda na ideia de que toda pessoa, em qualquer lugar do mundo, independente de cidadania ou localização, possui alguns direitos básicos que devem ser respeitados. O que é notório é que segurança é um direito humano em si, conforme previsto no artigo 3 da Declaração Universal dos Direitos Humanos (DUDH): “[t]odas as pessoas têm direito à vida, à liberdade e à segurança pessoal” (OHCHR, 1948) e tal direito é visto como uma obrigação do Estado. Tadjbakshsh, Chenoy (2007, p. 74) ainda 
afirmam que segurança, além de ser um direito fundamental, é um “grau 0” dos direitos humanos, que vem antes mesmo das três diferentes gerações de direitos (direitos políticos; direitos sociais e econômicos e direitos de diferença).

Dessa forma, o comprometimento com direitos humanos demanda que certas liberdades básicas dos indivíduos sejam respeitadas, auxiliadas e melhoradas. Assim, a natureza normativa do conceito dos direitos humanos o deixa em aberto a questões sobre quais liberdades especificamente são cruciais ou mesmo se existe uma hierarquia entre elas sob as quais a sociedade deveria reconhecer, salvaguardar e promover. Nesse sentido, quando liberdades e inseguranças se relacionam e se suplementam existe diálogo entre segurança humana e direitos humanos, uma vez que essa perspectiva de segurança busca libertar indivíduos de inseguranças - liberdade de necessidades (freedom from want), liberdade do medo (freedom from fear) e liberdade para agir por si. Não obstante, é necessário evidenciar que a compreensão do papel do Estado é configurada de forma distinta para ambas as abordagens, uma vez que os direitos humanos outorgam ao Estado o papel de responsável primário ou garantidor dos direitos fundamentais do indivíduo, mantendo uma visão estadocêntrica, até pelo seu caráter normativo; enquanto a segurança humana desconfia do mesmo, vendo-o como uma possível fonte de ameaças.

É possível afirmar, então, que a segurança humana complementa a segurança estatal, aprimora os direitos humanos e fortalece o desenvolvimento humano, conforme faz o relatório da CSH (SEN et al, 2003). Não existem contradições entre segurança humana, desenvolvimento humano e direitos humanos e, sim, complementariedades. Cada conceito foca em aspectos distintos do bem-estar diário do ser humano na busca para que ele tenha direitos fundamentais, seja capaz e livre de ameaças para exercer tais direitos de forma econômica, social e política. Contudo, a definição do RDH para segurança humana é ampla e atores fazem interpretações bastante distintas da mesma, conforme poderemos ver no relatório que será discutido a seguir.

\section{Segurança humana sob o olhar do novo milênio}

Como afirmamos anteriormente, a RSH foi criada para promover o conceito de segurança humana como política e seu objetivo era influenciar a agenda de segurança internacional em 1999. A iniciativa partiu dos governos do Canadá e 
da Noruega (MACFARLANE, KHONG, 2006), sendo composta por ministros das relações exteriores de 13 países que, com encontros anuais, concordaram em buscar iniciativas coordenadas, formais e informais. No primeiro encontro, em Lysøen, o foco da visão da segurança humana era tanto sobre o indivíduo livre do medo (freedom from fear) quanto sobre o indivíduo livre de necessidades (freedom from want), mas os encontros subsequentes ampliaram ou desdobraram a lista de políticas ou objetivos programáticos focalizados na compreensão da segurança humana somente como liberdade do medo (freedom from fear).

É possível notar que a RSH funciona como uma facilitadora. Krause (2014) afirma que ela é uma formadora de agenda na área de proliferação e mau uso de armas leves, bens de conflito e crianças-soldado, sendo vista como uma extensão do grupo informal dos Estados que haviam trabalhado juntos com sucesso no processo de Ottawa sobre minas terrestres antipessoais (KRAUSE, 2014). Desta forma, a RSH abriu espaço para outras iniciativas em termos de formação de rede entre Estados dispostos a defender uma agenda específica, principalmente para a CIISE. Mesmo que não exista uma relação institucional entre ambas, o protagonismo do governo canadense nas duas iniciativas e sua leitura restrita do que era segurança humana são claras. A publicação final é realizada pelo Centro Internacional de Desenvolvimento de Pesquisa ${ }^{19}$, braço do governo canadense que financia pesquisa. Assim, o governo canadense cunha a Responsabilidade de Proteger em 2001, através da discussão da relação entre soberania estatal, intervenção e direito internacional. A Comissão possui como objetivo final produzir um Relatório que busca responder "se e quando é apropriado para estados tomarem ações coercitivas - e particularmente militares - contra outro estado pelo propósito de proteger pessoas em risco neste outro estado"20 (ICISS, 2001: p. vii).

Enquanto na dimensão de desenvolvimento temos o RDH como marco inicial para definir a abordagem, é possível argumentar que o marco inicial da agenda de segurança é o Relatório da CIISE. A Comissão é a reposta da comunidade internacional para as falhas e inações dos anos de 1990 em termos de intervenções humanitárias, ou seja, é a agenda de segurança focando na liberdade do medo (freedom from fear) e buscando compreender de que forma podemos falar do foco no indivíduo em termos de segurança sem ferir a soberania do Estado,

19 Ver https://www.idrc.ca/

20 “ (...) the question of when, if ever, it is appropriate for states to take coercive - and in particular military — action, against another state for the purpose of protecting people at risk in that other state." (ICISS, 2001: p. vii) 
bem como compreender qual é a responsabilidade da comunidade internacional para com esses indivíduos, uma vez que os próprios Estados não estão sendo capazes de suprir suas necessidades básicas e estão eles próprios, muitas vezes, violando direitos.

Contudo, o Relatório olha para a segurança humana através de uma percepção restrita, a da segurança do indivíduo de ameaças físicas somente, e essa é a primeira "definição" ou "contraproposta" que a agenda de segurança faz à definição do RDH. É possível argumentar que a conjuntura histórica dos anos de 1990, aliada à liderança canadense, induziu a discussão focada nas questões da soberania e intervenção humanitária, não permitindo que questões como desenvolvimento, saneamento básico ou empoderamento fossem incorporadas na compreensão de segurança do relatório. A CIISE é criada em setembro de 2000, pelo primeiroministro canadense do período, Jean Chrétien, com um mandato para construir uma compreensão mais ampla do problema de reconciliar intervenção com fins de proteção humana e soberania (ICISS, 2001), focando no desenvolvimento de políticas que buscassem tirar o sistema internacional, principalmente a ONU, da paralisia e erros dos anos de 1990 , a ser debatida e comunicada na $56^{a}$ sessão da AGNU. A Comissão contava também com o apoio de fundações dos EUA (MACFARLANE; KHONG, 2006).

Chefiada por Gareth Evans e Mohamed Sahnoun, a CIISE foi composta por outros 10 acadêmicos, diplomatas e políticos de diversas nacionalidades ${ }^{21}$, que redigiram o relatório de forma unânime. Cabe notar que a própria publicação ressalta que alguns membros gostariam de ter criado critérios mais amplos ou mais específicos e com maior ou menor flexibilidade para intervenção militar fora do escopo do Conselho de Segurança. Como reflexo de tal descompasso, foram constituídos um Conselho Consultivo, um Time de Suporte e um Time de Pesquisa. Além da composição da Comissão, para detalhar a elaboração do Relatório, existe, inclusive, um volume suplementar chamado "Pesquisa, Bibliografia e Background" (ICISS, 2001b), no qual 114 páginas detalham a bibliografia utilizada como base para o relatório como um todo, que contou com o auxílio do professor Neil MacFarlane da Universidade de Oxford, mais uma vez evidenciando que esse é

21 Mohamed Sahnoun (diplomata algeriano) e Gareth Evans (acadêmico e político australiano) são co-presidentes, acompanhados de: Gisèle Côté-Harper (advogada e acadêmica canadense), Lee Hamilton (político norteamericano), Michael Ignatieff (acadêmico e político canadense), Vladimir Lukin (ativista político russo), Klaus Naumann (ex-militar alemão), Cyril Ramaphosa (político, empresário e ativista sul-africano), Fidel Ramos (expresidente filipino), Cornelio Sommaruga (diplomata e advogado suíço), Eduardo Stein (diplomata e político guatemalteco) e Ramesh Thakur (acadêmico indiano). 
um esforço majoritariamente acadêmico, mas, no caso, ao contrário do RDH, com financiamento e suporte estatais 22 .

O Conselho Consultivo é presidido pelo ministro canadense Lloyd Axworthy e composto por personalidades políticas, acadêmicas e diplomáticas de diversas nacionalidades. Ele tinha a função de auxiliar a comissão a embasar o relatório em realidades políticas correntes e assistir na constituição de engajamento necessário para dar seguimento às recomendações do mesmo. O conselho se encontrou presencialmente com a comissão em junho de 2001, enquanto a comissão realizou cinco encontros entre 2000 e 2001 (Ottawa, em novembro de 2000; Maputo, em março de 2001; Nova Deli, em junho de 2001; Wakefield, em agosto de 2001; e Bruxelas, em setembro de 2001). Também existiu um encontro informal da comissão em Genebra em fevereiro de 2001, contando com membros presentes e via conference call, além de múltiplos encontros em pequenos grupos dos membros da comissão, mesas-redondas e consultas (ICISS, 2001).

Buscando enriquecer o conteúdo que deveria compor o relatório e garantir que a comissão ouvisse uma ampla variedade de visões ao longo de seu mandato, aconteceram onze mesas-redondas regionais e consultas nacionais ao redor do mundo, conduzidas entre janeiro e julho de 2001. Pelo menos um dos presidentes da comissão estava sempre presente nessas consultas. Outros membros da comissão incluíam atores governamentais, não governamentais e sociedade civil; universidades, instituições de pesquisa e think tanks. Antes de cada consulta, compartilhou-se entre esses participantes um documento com as principais questões sob a perspectiva da comissão para estimular o debate e participantes específicos foram convidados a preparar contribuições e apresentá-las para que a comissão pudesse utilizar a posteriori esse novo material produzido. Outro participante, em cada uma das mesas-redondas, foi selecionado para produzir um relatório resumido dos procedimentos e resultados de cada mesa.

A mesa-redonda de Santiago, por exemplo, foi presidida por Francisco Rojas Aravena da Faculdad Latinamericana de Ciencias Sociales do Chile e a fala inicial, feita pela ministra das Relações Exteriores do Chile, Maria Soledad Alvear, se referiu a intervenções como questões de vida ou morte, questões estas que as organizações internacionais não estavam sendo capazes de responder de forma apropriada, uma vez que violações e massacres continuavam ocorrendo. Ela

22 Foi financiada por organizações internacionais como Carnegie Corporation of New York, William and Flora Hewlett Foundation e a Simons Foundantion, além de pelo governo canadense, que doou um milhão de dólares e também recebeu contribuições do Reino Unido e Suíça. 
enfatizou, ainda, que a história da América Latina e do Caribe possui uma estrutura doutrinal que se opõe a intervenções unilaterais e favorece o respeito à soberania dos Estados. Por mais que a região confie na Carta da ONU, as decisões do CSNU podem ser bloqueadas pelos interesses de seus membros e assim não responder com a rapidez necessária às situações que demandam intervenção internacional e então ela sugeriu que como salvar vidas deve sempre ser o interesse maior, devemos ser capazes de criar mecanismos novos e originais (ICISS, 2001: p. 370). O documento inicial propunha a ideia de "multilateralismo cooperativo" como base para construir consenso e processo decisório nas questões centrais do sistema internacional, incluindo intervenção humanitária. Tal abordagem seria positiva, prática e baseada em ideais como paz e prosperidade, além de adotar um conceito de segurança mais holístico.

Tal proposta foi bem aceita pelos presentes, que concordaram na necessidade da revisão do conceito de segurança. Porém, não houve consenso sobre qual conceito deveria ser utilizado. O próprio suplemento do relatório afirma: “devido à falta de ferramentas teóricas compreensivas para explicar os fenômenos mais recentes dentro da arena internacional, novos nomes, como 'segurança ambiental', 'segurança cidadã', e 'segurança humana', têm aparecido” (ICISS, 2001: p. 371)23, enquanto outros preferem ampliar o conceito de segurança para incluir novas ameaças, atores e relações de poder. Além disso, sugeriu-se que a própria globalização tornara o conceito de soberania obsoleto, uma vez que as ameaças atuais, novas ou antigas, são de natureza transnacional e, dessa forma, ignoram fronteiras territoriais. Outros pontos discutidos na mesa-redonda foram: (i) quando a intervenção militar externa deve ser considerada e por que, inclusive considerando as prioridades e limiares; (ii) quando não intervir e por que; (iii) o impacto de intervenções militares externas da perspectiva política, econômica e social; e (iv) intervenção “para democracia”.

Briefings regulares também eram realizados nas capitais governamentais, bem como nas missões diplomáticas em Ottawa, Genebra e Nova Iorque em junho de 2001, nas quais representantes da comissão se encontravam com representantes de diversas missões permanentes, bem como com o Secretário-Geral Kofi Annan e os principais membros do secretariado da ONU (ICISS, 2001). Paralelamente

23 "Because of a lack of comprehensive theoretical tools to explain the most recent phenomena within the international arena, new tag names, such as "environmental security," "citizen security," and "human security," have appeared. Others have preferred to broaden the traditional concept of international security to include new threats, actors, and power relationships." (ICISS, 2001: p. 371) 
às consultas, montou-se um programa de pesquisa extensivo para sustentar o trabalho da comissão e complementar os esforços também das mesas-redondas e das discussões que ocorreram na ONU, em níveis regionais e em demais fóruns. Assim, foi criado um time de pesquisa internacional, chefiado pelo americano Thomas Weiss ${ }^{24}$ e o zimbabuense Stanlak e Samkange 25 (ICISS, 2001). Weiss e seu consultor de pesquisa canadense, Don Hubert, assumiram a responsabilidade primária de produzir artigos de pesquisa para o volume suplementar, enquanto Samkange era o rapporteur e assistia a comissão na redação dos esboços do seu relatório. O objetivo por trás dessa iniciativa foi disseminar o conceito criado pelo relatório.

A Responsabilidade de Proteger é o conceito criado pelo relatório ao comparar intervenção humanitária com segurança humana, mas sua ênfase reside na primeira. Ele consiste basicamente na noção de que o Estado possui a responsabilidade de proteger a sua própria população de riscos de conflitos e repressão estatal ou colapso, enquanto a comunidade internacional possui a responsabilidade de intervir quando Estados são incapazes ou não querem assegurar seus nacionais e assegurar a liberdade do medo (freedom from fear) (ICISS, 2001;ALMQVIST, 2005).O conceito vem da mesma linha de pensamento da segurança humana ao referir-se aos direitos fundamentais do ser humano. Em gerenciamento de conflito, esses dois conceitos enfatizam a necessidade de focar novamente no indivíduo quando compreendemos segurança internacional e suas ameaças pela comunidade internacional. É importante mencionar que a comissão, ao longo do relatório, afirma, repetidamente, que acredita que intervenções devem ocorrer, mas somente em caso de violações massivas de direitos humanos, que sejam derivadas de conflitos internos, insurgência, repressão ou fraqueza do Estado ou quando o Estado é incapaz ou relutante por algum motivo em solucionar o problema. Contudo, a Responsabilidade de Proteger não abarca somente intervenção, uma vez que a comissão estabelece que a responsabilidade da comunidade internacional frente às questões humanitárias está dividida em três etapas: responsabilidade de prevenir, responsabilidade de reagir e responsabilidade de reconstruir (ICISS, 2001).

A compreensão da responsabilidade de prevenir é um desdobramento de algo que já vinha ocorrendo dentro das próprias Nações Unidas, cujas resoluções já tomavam uma posição de prevenção de conflitos. O relatório, então, enfatiza

24 É professor da City University of New York e também co-diretor do Projeto de História Intelectual da ONU.

25 Advogado e ex-redator de discursos do Secretário-Geral Boutros Boutros-Ghali. 
que para uma base sólida para prevenção de conflitos é necessário um forte comprometimento estatal a fim de assegurar o bem-estar dos cidadãos e a boa governança. Os avisos antecipados dos governos nacionais à ONU são tidos como soluções pelo documento, buscando deixar clara a situação do país.

De todo modo, a própria publicação já previa dificuldades, uma vez que o próprio Estado poderia não ser claro com tais dados, levantando uma questão de credibilidade. Ainda dependemos de organizações não governamentais como Anistia Internacional, Human Rights Watch, agências especializadas da ONU e outras que tem presença em campo para divulgação de dados de violações de direitos humanos para trabalhar na prevenção e aviso antecipados. Em convergência com a segurança humana, o relatório faz menção à perda de vidas de forma direta e arraigada. Perdas de vida de forma direta seriam por questões envolvendo liberdade do medo (freedom from fear) e as arraigadas envolvendo questões referentes à liberdade de necessidades (freedom from want), tais como pobreza, distribuição desigual de recursos e repressão política. A prevenção pode ser realizada através de fortalecimento institucional, podendo envolver inclusive o Secretário-Geral na busca de maior estabilidade econômica por meio da mediação de escritórios internacionais, por exemplo.

Já a responsabilidade de reagir entra em ação quando a prevenção falha e o Estado não é capaz ou se ausenta, pelos motivos mais variados, a acabar com as violações massivas aos direitos humanos. As medidas de reação, intervenção ou coerção podem ser econômicas, políticas ou jurídicas e, como último recurso ou casos extremos, a ação militar é considerada. Assim, o próprio relatório afirma que a intervenção militar a favor dos direitos humanos é uma medida extraordinária e excepcional e, sendo assim, ela deve respeitar os seguintes requisitos: causa justa $^{26}$, intenção correta, último recurso, medidas proporcionais e perspectivas razoáveis (ICISS, 2001).

O Relatório também discute os desdobramentos que vão além da prevenção e reação propriamente ditas, trazendo a questão da responsabilidade de reconstruir. Então, se ocorrer intervenção militar e houver incapacidade do Estado em prover mínima proteção aos seus nacionais, é necessário que exista um comprometimento da comunidade internacional na reconstrução das estruturas, incluindo meios de

26 Quando existe intenção ou perda de vida em grande escala, seja com intenções genocidas ou não, podendo partir do Estado como uma ação deliberada ou não, ou de sua incapacidade, negligência ou fragilidade; ou quando existe intenção ou "limpeza étnica" em larga escala, através de expulsão forçada, assassinato, atos de terror ou estupro (ICISS, 2001: p. 32). 
promover uma paz duradoura a partir da boa governança e do desenvolvimento sustentável (ICISS, 2001). Isso retoma a lógica da liberdade de necessidades (freedom from want) da segurança humana, uma vez que aqui a preocupação não é somente a segurança física do cidadão, mas seu bem-estar como um todo. O documento reconhece que, historicamente, a questão da responsabilidade da reconstrução não recebia o devido foco e era mal administrada, uma vez que a saída das forças que intervinham não era planejada e sim descompromissada. Além disso, existe um componente importante na construção da paz que consiste em colocar antigos oponentes lado a lado, para trabalhar na construção da paz e reconstruir seu país, buscando criar emprego, moradia e novas condições de vida, o que muitas vezes depende de um mediador internacional. Em suma, o relatório enfatiza três áreas onde a reconstrução deve focar: segurança, justiça e desenvolvimento econômico.

Na elaboração desse relatório, também é possível observar uma participação significativa de pesquisadores e debate acadêmico na construção do que seria a segurança humana ou mesmo da forma pela qual a intervenção humanitária seria "reinterpretada" aos olhos da segurança humana, o que resultou na Responsabilidade de Proteger. A participação e envolvimento dos Estados, organizações internacionais e atores da sociedade civil acontecem de maneira mais contundente, em uma verdadeira tentativa de construir uma rede de advocacy transnacional. Mesmo assim, é possível notar que a interpretação do governo canadense do que é segurança humana, restrita e focada na ausência de ameaças física (freedom from fear), acaba por influenciar o conteúdo final do mesmo de forma latente - por mais que exista um notável esforço na composição da variedade de nacionalidades entre os especialistas envolvidos no processo.

A primeira "contraproposta" da agenda da segurança ao conceito de segurança humana surge então ainda influenciada de forma significativa pela segurança tradicional, com foco no Estado como provedor de segurança e nas ameaças físicas somente, praticamente ignorando a ampliação dos temas de segurança que vinha ocorrendo desde o final da Guerra Fria. Como consequência, discutem somente quando e como atores internacionais devem intervir para proteger indivíduos em casos nos quais seus governos são incapazes de oferecer proteção ou são os próprios violadores de direitos. É possível argumentar que o segundo estágio da segurança humana perde o foco do conceito e retorna para a concepção tradicional da segurança. 


\section{Conclusões}

Neste artigo, analisamos o percurso da segurança humana a partir do RDH, em 1994,para o seu segundo estágio de construção, quando foi reavivado em uma interpretação distinta no relatório da CIISE. O primeiro surge de uma perspectiva mais holística de segurança humana, que incluía a percepção que o indivíduo deveria estar livre de necessidades (freedom from want) e livre do medo (freedom from fear) de forma indivisível e indissociável para que a segurança fosse conquistada. Já o segundo se ocupa quase exclusivamente da visão do indivíduo livre do medo (freedom from fear), ou seja, de ameaças à sua integridade física. Tal fato dissocia termos que deveriam ser, teoricamente, indissociáveis - o desenvolvimento e a proteção. Essa dissociação ocorre através de temas mais tradicionais da agenda de segurança, ao travar o debate de intervenção humanitária com segurança humana no relatório do CIISE, fazendo com que a relevância seja a ação militar e não o empoderamento e o foco no indivíduo. Além do gap temporal significativo entre os dois relatórios (1994 e 2001), cada um assume um compromisso e uma pretensão de responder aos mesmos desafios, mas focando ou compreendendo as ameaças de forma distintas.

É relevante notar que ambos são resultados de esforços de atores governamentais e não governamentais, mas que contam também com uma significativa participação de pesquisas acadêmicas e que a estrutura de confecção desses documentos possui funcionamento, objetivo e desenho bastante semelhantes às pesquisas acadêmicas, mesmo que tenham suas estruturas alocadas dentro de organismos internacionais. Os dois documentos são exemplos do esforço em aproximar a teoria da prática, para que seja possível responder às oscilações constantes da dinâmica política internacional de forma razoavelmente contundente e embasada.

Contudo, a partir da grande diferença temporal e da falta de debate entre a primeira definição de segurança humana no RDH e a definição proposta pelos acadêmicos e Estados patrocinadores do relatório CIISE, houve uma divisão da agenda do conceito de segurança humana em duas vertentes: (1) uma visão mais ampla de segurança e desenvolvimento e (2) uma visão vinculada à proteção de civis em conflitos armados. Essa dicotomia, inclusive, fica clara na apropriação feita pelos Estados quando aplicam a segurança humana: enquanto o Japão tem a sua visão de segurança humana focada na primeira vertente, o Canadá tem a sua focada na segunda. Assim, na agenda de desenvolvimento, temos o RDH como marco inicial para definir a abordagem, porém o marco inicial da agenda de 
segurança, no que tange uma proposta ou mesmo resposta ao primeiro relatório, é o CIISE. A partir desses elementos, foi possível notar baixa convergência entre ambos relatórios com relação à construção da segurança humana, o que acaba comprometendo sua aplicabilidade prática - conforme exemplo dos países citados acima. Tal divisão faz com que a segurança humana permaneça sem definição clara, uma vez que cada ator escolhe a vertente que melhor se encaixa às suas necessidades e interesses.

\section{Referências}

ALMQVIST, Jessica. Building a New Role for the United Nations: the Responsibility to Protect. A Roundtable Discussion on the Recommendations on UN Reform Madrid: FRIDE, 2005.

BUZAN, Barry. A Reductionist, Idealistic Notion that Adds Little Analytical Value. Security Dialogue, Vol 35, Issue 3, 2004: 369-370. Disponível em: http://journals.sagepub. com/doi/abs/10.1177/096701060403500326. Último Acesso em: nov. 2016.

BURGESS, Peter; et al. What is Human Security. Security Dialogue. vol. 35, no. 3, September, 2004. Disponível em: http://journals.sagepub.com/toc/sdib/35/3 Último Acesso em: nov. 2016.

HAMPSON, Fen Osler; et al. Madness in the Multitude: Human Security and World Disorder. Ottawa: Oxford University Press, 2002.

HSU. "HS Handbook.” HS Handbook. 2009. http://www.un.org/humansecurity/sites/ www.un.org.humansecurity/files/human_security_in_theory_and_practice_english.pdf. Último Acesso em: nov. 2016.

ICISS. The Responsibility to Protect. Ottawa: International Development Research Centre, 2001. ICISSb. The Responsability to Protect - Research, Bibliography, Background. Ottawa: International Development Research Centre, 2001.

JAHAN, Selim. Entrevista: Selim Jahan. Diretor do Escritório do Relatório do Desenvolvimento Humano, jun. 2016. Entrevista concedida a Raquel Maria de Almeida Rocha.

KALDOR, Mary. Human Security. Cambridge: Polity, 2007.

KRAUSE. Critical perspectives on human security. In MARTIN, Mary; OWEN, Taylor (edits.) Routledge Handbook on Human Security, New York: Routledge, 2014, p. 76-93. MACFARLANE, Neil; KHONG, Yuen. Human Security and the UN A Critical History. Bloomington: Indiana University Press, 2006.

MARTIN, Mary; OWEN, Taylor. Routledge Handbook on Human Security,. Oxford: Routledge, 2015. 
MARTIN, Mary; OWEN, Taylor. The second generation of human security: lessons from the UN and EU experience. International Affairs. Volume 86, Issue 1, January 2010: p. 211-224. Disponível em: http://onlinelibrary.wiley.com/doi/10.1111/j.14682346.2010.00876.x/abstract Último Acesso em: nov. 2016.

MCRAE, Rob; HUBERT, Don. Human Security and the New Diplomacy: Protecting People, Promoting Peace. Montreal: McGill-Queen's University Press, 2001.

MUKHOPADHYAY, Tanni. Entrevista: Tanni Mukhopadhyay. Senior Researcher and Policy Specialist, jun. 2016. Entrevista concedida a Raquel Maria de Almeida Rocha.

NEF, Jorge. Human Security and Mutual Vulnerability The Global Economy of Development and Underdevelopment. Ottawa: International Development Research Centre, 1999. NEWMAN, Edward. Critical human security studies. Review of International Studies. Volume 36 Issue 1, 2010: p. 77-94. Disponível em: https://www.cambridge.org/core/ journals/review-of-international-studies/article/critical-human-security-studies/5F 1FD24C399B41FC77A5A1E677365AE5 Último acesso em: mai. 2016

OHCHR. Convention on the Rights of the Child. 1989. Disponível em: http://www.ohchr. org/Documents/ProfessionalInterest/crc.pdf Último Acesso em: jan. 2016.

OHCHR. Convention on the Elimination of All Forms of Discrimination against Women. 1979. Disponível em: http://www.ohchr.org/Documents/ProfessionalInterest/cedaw. pdf Último Acesso em: jan. 2016.

OHCHR. Declaração Universal dos Direitos Humanos. 1948. Disponível em: http://www. ohchr.org/EN/UDHR/Documents/UDHR_Translations/por.pdf Último Acesso em: nov. 2016.

OWEN, Taylor. The Critique That Doesn't Bite: A Response to David Chandler's 'Human Security: The Dog that Didn't Bark'. Security Dialogue. Vol 39, Issue 4, 2008: p. 445. Disponível em: http://journals.sagepub.com/doi/abs/10.1177/0967010608094038?j ournalCode = sdib Último Acesso em: dez. 2016.

PARIS, R. Human Security: Paradigm Shift or Hot Air? International Security, vol. 26, n.2, 2001, p. 87-102. Disponível em: http://aix1.uottawa.ca/ rparis/Paris.2001. IS.Human\%20Security.pdf Último Acesso em: dez. 2016.

ROTBERG, Robert. "Failed States, Collapsed States, Weak States: Causes and Indicators.” In State Failure and State Weakness in a Time of Terror, by R ROTBERG, 1-25. Whashington: Brookings Institution Press, 2003.

SEN, Amartya; et al. Human Security Now. Comission on Human Security Report. New York: Comission on Human Security, 2003.

SEN, Amartya. Development as freedom. 1st ed. New York: Oxford University Press, 1999. TADJBAKHSH, Shahrbanou; CHENOY, Anuradha. Human Security Concepts and Implications. Abingdon: Routledge, 2007. 
TADJBAKHSH, Shahrbanou. "Human Security: Concepts and Implications with an application to Post-Intervention Challenges in Afghanistan.”Lés Études du CERI No 117-118, 2005. Disponível em: http://www.sciencespo.fr/ceri/sites/sciencespo. fr.ceri/files/etude117_118.pdf Último acesso em: nov. 2015.

UL HAQ, Mahbub. Reflections on Human Development. New York: Oxford University Press, 1995.

UN. A more secure world: our shared responsibility. 2004. Disponível em: http://www. un.org/en/peacebuilding/pdf/historical/hlp_more_secure_world.pdf Último Acesso em: 08/2016.

UN. General Assembly. A/RES/57/264. 30 January 2003. Disponível em: https://documentsdds-ny.un.org/doc/UNDOC/GEN/N02/556/72/PDF/N0255672.pdf?OpenElement Último acesso em: 01/2016.

UN. Comission on Human Security. Human Security Now. New York: 2003. Disponível em: http://www.un.org/humansecurity/sites/www.un.org.humansecurity/files/ chs_final_report_-_english.pdf. Último Acesso em: ago. 2016.

UN. Supplement to An Agenda for Peace. 1995.

UN. The responsibility of the Security Council in the maintenance of international peace and security. New York: UN, 1992.

UN. Convention on the Prevention and Punishment of the Crime of Genocide. 1948. Disponível em: https://treaties.un.org/doc/publication/unts/volume\% 2078/volume78-i-1021-english.pdf Último acesso em: jan. 2016.

UNCHR. The State of The World's Refugees 1997: A Humanitarian Agenda. Disponível em: http://www.unhcr.org/publications/sowr/4a4c72719/state-worlds-refugees1997-humanitarian-agenda.html Último acesso em: ago. 2016.

UNCHR. Convention and Protocol Relating to the Status of Refugees. 1951. Disponível em: http://www.unhcr.org/3b66c2aa10.pdf Último acesso em: jan. 2016.

UNDP. The Human Development Report. The Human Development Reports Office.New York: UN, 2015.

UNDP. Human Development Report 2014 Sustaining Human Progress: Reducing Vulnerabilities and Building Resilience. New York: PBM Graphics, 2014.

UNDP. Human Development Report.The Human Development Reports Office.New York: UN, 2011.

UNDP. Human Development Report. The Human Development Reports Office.New New York: UN, 2006.

UNDP. Human Development Report. An Agenda for the Social Summit. Oxford: Oxford University Press. 1994. Disponível em: http://hdr.undp. org/en/media/hdr_1994_ en_overview.pdf. Último Acesso em: mar. 2016. 
UNDP. Human Development Report 1993: People's participation. New York, 1993.

UNIC. ABC das Nações Unidas. Rio de Janeiro: UNIC RIO, 2009.

UNOCHA. Human Security at the UN - Human Security Unit. [s/d]. Disponível em: http://unocha.org/humansecurity/about-human-security/human-security-un Último Acesso em: ago. 2016.

VILLA, R. “A segurança global multidimensional.” Lua Nova, 1999: 99-119.

WILLIAMS, Paul. Security Studies: An introduction. New York: Routledge, 2008. 


\title{
“Ganhei na loteria! Mas e o prêmio?”: a mobilização sócio-legal do direito internacional dos direitos humanos no caso da guerrilha do Araguaia ${ }^{1}$
}

\author{
"I have won the lottery! What about the prize?": \\ the socio-legal mobilization of the international \\ human rights law in the case of the Araguaia
} guerrilla movement

DOI: $10.21530 /$ ci.v12n3.2017.687

Bruno Boti Bernardi²

\section{Resumo}

Tendo como base as perspectivas de usuários do sistema interamericano de direitos humanos no caso Gomes Lund (guerrilha do Araguaia), o objetivo deste artigo é discutir as potencialidades e eventuais limites da mobilização sócio-legal do direito internacional dos direitos humanos. Utilizando o marco teórico da literatura sobre disputas jurídico-legais dos movimentos sociais nos planos doméstico e transnacional, argumenta-se que o litígio produziu experiência empoderadora no plano ideacional-simbólico, impactando a agenda política nacional e fortalecendo tanto a mobilização social quanto o potencial de contestação jurídico-legal nos tribunais nacionais, muito embora o cumprimento do Estado com a sentença seja baixo em termos de decisões judiciais e mudanças de políticas públicas. Porém, devem ser levados em conta efeitos potencialmente limitadores da mobilização do direito sobre a prática política de atores e movimentos sociais. A natureza normatizada, burocrático-legal e altamente complexa do direito internacional dos direitos humanos pode impor constrangimentos à linguagem e às estratégias contestatórias de atores societais.

Palavras-chave: Brasil; mobilização sócio-legal; sistema interamericano de direitos humanos; guerrilha do Araguaia; atores societais.

1 Pesquisa realizada com ajuda financeira da Fundação de Amparo à Pesquisa do Estado de São Paulo (Fapesp) (processo 2011/50059-6) e do programa Capes-Proex do Departamento de Ciência Política da USP. O autor agradece aos pareceristas anônimos da Carta Internacional e às pessoas entrevistadas durante a pesquisa, com destaque para as familiares de mortos e desaparecidos políticos no Araguaia.

2 Faculdade de Direito e Relações Internacionais na Universidade Federal da Grande Dourados (UFGD), Dourados/MS, Brasil. E-mail: brunoboti@gmail.com

Artigo submetido em 03/07/2017 e aprovado em 11/12/2017. 


\section{Abstract}

Based on the perspectives of the users of the Inter-American Human Rights System in the Gomes Lund (Araguaia guerrilla movement) case, the aim of this article is to discuss the potentialities and limitations of socio-legal mobilization in the international human rights law field. Using the theoretical framework of the literature on legal disputes envolving social movements at the domestic and transnational levels, it is argued that although the state's compliance with the ruling is low in terms of judicial decisions and changes in policies, the litigation process has produced an empowering experience in ideational and symbolic terms, impacting the national political agenda and strengthening both the social mobilization and the challenging legal tactics in the national courts. However, potentially limiting effects of the mobilization of law on the political practice of social actors and movements must be taken into account. The normatized, bureaucratic-legal, and highly complex nature of international human rights law may constrain the language and contentious strategies of societal actors.

Keywords: Brazil; socio-legal mobilization; Inter-American Human Rights System; Araguaia guerrilla movement; societal actors.

\section{Introdução}

Durante a ditadura militar brasileira, milhares de graves violações de direitos humanos foram perpetradas por agentes do Estado, configurando um padrão sistemático de abusos. Na área limítrofe entre os Estados do Pará, Tocantins e Maranhão, entre 1972 e 1975, ao longo de três investidas militares contra a guerrilha do Araguaia, o regime militar foi responsável pela detenção arbitrária, tortura e desaparecimento forçado de ao menos setenta pessoas, entre camponeses e militantes do Partido Comunista do Brasil (PCdoB).

Em 1995, duas décadas após o fim da guerrilha, e em resposta à falta de resultados de uma ação interna na justiça brasileira iniciada em 1982 que buscava elucidar o incidente, familiares das vítimas, agrupados na Comissão de Familiares de Mortos e Desaparecidos Políticos (CFMDP) e no Grupo Tortura Nunca Mais do Rio de Janeiro (GTNM-RJ), enviaram o caso para a Comissão Interamericana de Direitos Humanos (CIDH) com a ajuda do então escritório conjunto do CEJIL (Center for Justice and International Law) e Human Rights Watch/Americas do Rio de Janeiro. Quinze anos depois, em 2010, a Corte Interamericana de Direitos Humanos (CoIDH) condenou o Brasil no caso Gomes Lund (guerrilha do Araguaia), invalidando a Lei de Anistia 6.683 de 1979 (COIDH, 2010). Para a CoIDH, a lei garante a impunidade dos agentes estatais envolvidos em graves violações de 
direitos humanos e, por conta disso, não deve ser aplicada, uma vez que desrespeita a obrigação de investigar, processar e punir decorrente da Convenção Americana de Direitos Humanos, aderida pelo Brasil em 19923.

Em abril de 2010, sete meses antes da emissão dessa sentença, e já tendo em vista o provável conteúdo da decisão da CoIDH, o Supremo Tribunal Federal (STF) decidiu preventivamente em favor da constitucionalidade da Lei de Anistia no julgamento da arguição de descumprimento de preceito fundamental ADPF 153. O objetivo era neutralizar a eventual condenação e salvaguardar a controversa interpretação judicial hegemônica segundo a qual os crimes comuns praticados pelos agentes do Estado teriam sido anistiados por tratarem-se de crimes conexos aos crimes políticos previstos pela legislação.

Entretanto, apesar dessa e de outras seguidas derrotas nos tribunais nacionais, a condenação do Brasil impulsionou uma alteração na postura da cúpula do Ministério Público Federal (MPF) em favor da posição defendida por um grupo minoritário de procuradores mais progressistas e abertos ao direito internacional dos direitos humanos, os quais ajuizaram 27 ações penais sobre violações da ditadura até o início de 2017 (BRASIL, 2017). Assim, os esforços em favor da persecução criminal individual seguem em curso, ancorados na sentença da CoIDH, a mais importante ferramenta jurídico-legal disponível para confrontar a decisão do STF na ADPF 153.

De modo geral, porém, no que tange à implementação e cumprimento global dos pontos resolutivos da sentença, o Brasil pouco avançou. Na resolução de supervisão de cumprimento da sentença de 2014, a CoIDH faz uma avaliação ainda válida: excetuando medidas indenizatórias e a criação da Comissão Nacional da Verdade, a situação é de ausência de resultados na responsabilização penal dos perpetradores das violações; na localização das vítimas desaparecidas; na

3 No tocante à hierarquia das normas internacionais de direitos humanos dentro do ordenamento jurídico brasileiro, desde a incorporação do parágrafo $3^{\circ}$ ao artigo $5^{\circ}$ da Constituição Federal por meio da Emenda Constitucional (EC) n. 45/2004, os tratados e convenções internacionais sobre direitos humanos que forem aprovados, em cada Casa do Congresso Nacional, em dois turnos, por três quintos dos votos dos respectivos membros, terão status constitucional. Já os tratados posteriores à EC 45/2004 que não sejam aprovados por maioria qualificada, isto é, por três quintos dos votos, em dois turnos, pela Câmara dos Deputados e Senado, receberão apenas status infraconstitucional, de legislação ordinária. Em 2008, o Supremo Tribunal Federal decidiu em favor da tese da supralegalidade para os tratados de direitos humanos incorporados ao direito brasileiro antes da EC 45/2004, como a Convenção Americana de Direitos Humanos. Nesses casos, o status dos tratados situa-se acima de todas as leis ordinárias do país, mas abaixo da Constituição (cf. Ramanzini, 2014). Por sua vez, no que diz respeito à relação do Brasil com o sistema interamericano de direitos humanos, os pronunciamentos da Comissão Interamericana de Direitos Humanos têm caráter de recomendações, enquanto os julgamentos da Corte Interamericana de Direitos Humanos constituem sentenças de natureza vinculante. 
publicação dos arquivos militares sobre a guerrilha e na implantação de programa permanente e obrigatório de direitos humanos para todos os membros das Forças Armadas (COIDH, 2014, p. 41-42).

Frente a esse panorama, tendo como base as perspectivas de usuários do sistema interamericano de direitos humanos (SIDH) no caso Gomes Lund, o objetivo deste artigo é discutir as potencialidades e eventuais limites da mobilização sócio-legal do direito internacional dos direitos humanos. A partir da análise de entrevistas qualitativas semiestruturadas realizadas com familiares de mortos e desaparecidos políticos na guerrilha do Araguaia ${ }^{4}$, argumenta-se que, embora o cumprimento do Estado com a sentença seja baixo em termos de decisões judiciais e mudanças de políticas públicas, o litígio produziu experiência empoderadora no plano ideacional-simbólico, impactando a agenda política nacional e fortalecendo tanto a mobilização social quanto o potencial de contestação jurídico-legal nos tribunais nacionais. Em outras palavras, ainda que a implementação da decisão pelo Estado seja escassa, a sentença produziu impactos significativos.

A fim de avaliar tal proposição, faz-se referência, na primeira seção do texto, à literatura sobre a mobilização do direito. Destacam-se tanto as contribuições focadas na dimensão nacional das disputas jurídico-legais dos movimentos sociais (MCCANN, 1994; 1998; 2006; 2010) quanto os trabalhos sobre o transnacionalismo legal (KAY, 2011) e as consequências domésticas dos compromissos internacionais de direitos humanos (SIMMONS, 2009). Em seguida, outras duas seções do texto analisam, respectivamente, as potencialidades e entraves gerados pela mobilização sócio-legal transnacional no caso Gomes Lund. Por fim, nas conclusões, apresenta-se um balanço do caso da guerrilha do Araguaia, salientando a necessidade de que a literatura se atente mais para efeitos potencialmente limitadores da mobilização do direito internacional para a prática política de atores e movimentos sociais.

4 Para estabelecer a lista dos parentes das vítimas mais ativos em relação à promoção do caso no SIDH, procedeu-se ao cruzamento de referências e nomes a partir do contato com familiares de São Paulo e diferentes advogadas do CEJIL que litigaram o caso, o que produziu uma relação de pessoas a entrevistar, posteriormente checada com familiares do Rio de Janeiro. No total, sete pessoas da CFMDP e do GTNM-RJ foram entrevistadas consensualmente em 2014, pessoalmente ou via Skype. A relação completa das entrevistas encontra-se no apêndice. 


\section{A mobilização sócio-legal do direito internacional dos direitos humanos como recurso de interação política, jurídica e social}

\section{A dimensão ideacional e simbólica: enquadramentos interpretativos e consciência de direitos}

Durante o processo de formação organizacional, estabelecimento da agenda e construção dos movimentos, ativistas sociais e grupos marginalizados podem capitalizar as percepções, associadas às normas legais, de que são portadores de direitos, para iniciar e nutrir a mobilização política, o que fomenta a criação de uma consciência de direitos (MCCANN, 1998, p. 83; 2006, p. 25-6). Segundo McCann, os ativistas podem usar as normas para nomear, desafiar, explicar e enquadrar interpretativamente (frame) os problemas e injustiças sociais existentes; para definir as aspirações e objetivos coletivos do grupo; e para construir uma identidade comum entre os membros do movimento (ibidem). Desse modo, normas e mecanismos legais fornecem um enquadramento interpretativo para as demandas dos movimentos, permitindo-lhes articular uma histórica causal mais ampla sobre as relações sociais existentes, que sinaliza os culpados pelos problemas bem como as melhores vias para solucioná-los (idem, 1998, p. 84).

De modo similar, Simmons (2009) argumenta que os tratados internacionais de direitos humanos e suas normas influenciam positivamente a probabilidade de que ativistas se mobilizem para reivindicar os direitos contidos nos acordos. Do ponto de vista ideacional, os tratados disseminam novas informações e ideias persuasivas a potenciais demandantes, fazendo não só com que eles se imaginem como portadores de direitos, mas também os encorajando a valorizar o conteúdo substantivo das normas, de modo a afetar a forma como indivíduos e grupos concebem sua identidade e definem seus interesses (SIMMONS, 2009, p. 139-40). Assim, os padrões legais internacionais sugerem aos indivíduos novas maneiras possíveis de entender a sua relação com o Estado, despertando a consciência dos direitos e fornecendo enquadramentos alternativos por meio dos quais grupos e setores oprimidos podem adquirir um novo sentido de identidade política e legitimidade (ibidem, p. 141).

Por fim, Kay (2011) também salienta que as normas internacionais podem fazer mais do que permitir e tornar possível a formulação de reivindicações de direitos pelos ativistas, uma vez que elas também teriam impacto sobre o processo de formação de identidades coletivas e interesses transnacionais, afetando, por 
conseguinte, a forma como os ativistas se veem em relação aos Estados e outros atores. Segundo a autora, a mobilização do direito "pode ajudar a catalisar movimentos, recrutar membros, promover consciência de direitos e fomentar a solidariedade entre ativistas do movimento" (KAY, 2011, p. 421), facilitando assim a construção de interesses comuns e identidades coletivas coesas, elementos cruciais para o desenvolvimento dos movimentos sociais.

\section{A dimensão político-estratégica: potencial de surgimento e impacto da ação coletiva}

Uma segunda maneira por meio da qual as práticas legais podem contribuir para a emergência e posterior desenvolvimento dos movimentos sociais se dá por meio da reconstrução da estrutura de oportunidades políticas dentro da qual tais atores estão inseridos (MCCANN, 1998; 2006) ${ }^{5}$. A mobilização do direito e a advocacia legal de causas expõem vulnerabilidades das autoridades estatais e concedem saliência e legitimidade à reivindicação de direitos e de justiça dos ativistas, o que aumenta as chances de sucesso das suas estratégias de ação e pressão sobre o Estado. De acordo com McCann (1998), a transformação aqui envolve menos o esclarecimento de novos valores e entendimentos ou a revelação de injustiças e mais um reconhecimento de que aumentaram as chances de desafiar essas injustiças (MCCANN, 1998, p. 85).

De maneira correlata, Kay (2011) argumenta que normas e mecanismos legais favoráveis podem servir como importantes sinais aos movimentos sociais, encorajando-os não só a mobilizar o direito e táticas de litígio, mas também a utilizar outras estratégias que testem e tensionem os limites das fronteiras legais e das estruturas de oportunidades políticas estabelecidas. Assim, a autora afirma que, além de poder criar arenas jurídico-adjudicatórias internacionais que permitem o engajamento de ativistas de diversos países uns com os outros, "leis internacionais que definem e reconhecem direitos transnacionais podem facilitar a mobilização ao permitir que os ativistas façam reivindicações de direitos e ao legitimar o interesse coletivo dos ativistas de proteger seus direitos” (KAY, 2011, p. 424).

Nesse sentido, quando um tribunal ou mesmo um órgão semijudicial atuam - casos respectivamente da Corte e Comissão Interamericanas - , eles podem

5 De acordo com Sikkink (2005, p. 155), estruturas domésticas de oportunidades políticas referem-se a "quão abertas ou fechadas (...) as instituições domésticas estão perante a participação e pressões de redes e movimentos sociais”. 
aumentar a relevância da questão na agenda pública; privilegiar algumas partes que tenham demonstrado interesse na questão; criar novas oportunidades para essas partes se mobilizarem em torno da causa; e fornecer recursos simbólicos para esforços de mobilização em diversos campos. (MCCANN, 2010, p. 186)

Ademais, a facilitação da mobilização coletiva decorrente desses efeitos pode ainda incitar novos litígios e estimular outros tipos de ações e iniciativas políticas que não apenas aquelas restritas ao âmbito jurídico-legal, como táticas de lobby e campanhas midiáticas (ibidem). Assim, à medida que os ativistas utilizam essas novas oportunidades, eles adquirem maior confiança e sofisticação na sua capacidade de mobilizar normas e convenções legais para apontar problemas, indicar responsáveis e defender suas causas. Dessa maneira, gera-se um novo senso de eficácia: pessoas que antes se consideravam desamparadas passam a acreditar que têm capacidade para alterar sua sorte (MCCANN, 1998, p. 85).

A esse respeito, Simmons (2009) também ressalta que, para além da dimensão dos valores e das ideias, os tratados e normas internacionais influenciam ainda o componente mais estratégico do valor esperado da mobilização, afetando os recursos e estrutura de oportunidades políticas dos movimentos sociais. Segundo a autora, um tratado produz vários efeitos que aumentam as chances de mobilização bem-sucedida. Em primeiro lugar, ele compromete de antemão o governo a ser mais receptivo a demandas formuladas em termos dos direitos inscritos no acordo. Isso porque, depois da ratificação, fica mais difícil para o governo negar a importância da promoção dos direitos sem incorrer em acusações de inconsistência entre seus compromissos e suas práticas (SIMMONS, 2009, pp. 144-5).

Em segundo lugar, tratados de direitos humanos fornecem recursos intangíveis aos defensores de direitos, imbuindo suas queixas de legitimidade, já que eles sinalizam o acordo existente no plano interestatal sobre as melhores práticas disponíveis em termos de direitos. Dessa maneira, eles podem se converter em: pontos de referência, a partir dos quais grupos e indivíduos se asseguram de que suas exigências são razoáveis e legítimas; pontos focais em torno dos quais os demandantes podem coordenar e priorizar seus esforços; e modelos de legislação doméstica, os quais podem ser utilizados por ONGs e movimentos sociais (ibidem, p. 146-7).

Finalmente, a ratificação de um tratado e a emissão de uma decisão internacional de direitos humanos aumentam o conjunto de estratégias possíveis das quais um 
movimento social pode se valer para alcançar seus objetivos, incluindo formas de ação parcialmente institucionalizadas. Abre-se a oportunidade para utilizar leis, políticas e outras alavancas institucionais oficiais, exercendo uma espécie de resistência legal dentro dos marcos dos compromissos reconhecidos pelo Estado, resistência essa que não necessariamente se restringe apenas aos tribunais, como no caso dos litígios, e que pode, ademais, explorar as divisões dentro do Estado entre órgãos e burocracias mais ou menos inclinados à promoção dos direitos humanos (ibidem, pp. 147-8).

Além disso, Simmons (2009) aponta ainda um mecanismo adicional de ampliação da estrutura de oportunidades políticas, cujo impacto principal é sentido na agenda nacional de prioridades de políticas das elites político-institucionais, apesar de se fazer refletir também nas perspectivas de mobilização coletiva dos atores sociais, ao ampliar suas possibilidades discursivas. Normas internacionais de direitos humanos introduzem questões, conteúdos e enquadramentos normativos exógenos aos canais tradicionais de produção legislativa e de formulação de políticas de um país, alterando potencialmente os termos dos debates realizados até então (ibidem, pp. 127-9; 149). Direitos e temas de políticas estranhos, negligenciados ou não prioritários nas agendas nacionais, mas que foram negociados internacionalmente, são incorporados ao circuito político-institucional e passam a afetar o conjunto de opções legítimas de políticas dos governos, excluindo certas possibilidades antes existentes e recolocando as reformas pró-direitos em uma posição mais alta na agenda nacional (ibidem, p. 128). Isso pode, por um lado, legitimar e ampliar os frames dos ativistas e, por outro, fomentar e facilitar a mobilização coletiva de atores sociais demandantes nessas matérias.

Como resultado, mudanças legislativas e desenhos de políticas orientados para a questão dos direitos humanos, que anteriormente eram inexistentes ou impensáveis, podem ser impulsionados pela necessidade de levar em consideração a ratificação de um tratado ou uma decisão internacional condenatória. Cresce a probabilidade desse tipo de resposta porque o silêncio diante de um direito - que se tornou saliente por meio de negociações internacionais e que foi reconhecido formalmente pelo Estado - pode ser facilmente interpretado como uma postura de oposição ao tratado ou ao órgão internacional, o que pode comprometer a legitimidade e reputação do regime doméstico, retratado a partir de então como um violador de obrigações internacionais que estaria de fora do in-group da comunidade de nações democrático-liberais respeitadoras dos direitos humanos. 


\section{A dimensão instrumental das táticas legais e de litígio: ferramentas institucionalizadas de pressão nos tribunais e na implementação de políticas}

No plano da atuação societal, além de afetarem interesses, identidades coletivas e enquadramentos normativos, contribuindo ainda para a ampliação da estrutura de oportunidades políticas que favorece a emergência e reverberação da ação coletiva, normas, convenções e decisões legais também são recursos instrumentais usados por atores e movimentos sociais para a consecução de finalidades específicas e resultados práticos tangíveis. A esse respeito, McCann (2010) afirma que “O Direito (...) é uma linguagem, um conjunto de lógicas, valores e entendimentos que as pessoas conhecem, esperam, aspiram e se sentem portadoras. E o Direito também é um conhecimento instrumental sobre como agir para alcançar esses fins" (MCCANN, 2010, p. 189).

McCann (2006) assinala que o litígio e a advocacia legal oferecem aos ativistas sociais uma fonte de alavancagem institucional, simbólica e tática, contra seus oponentes e contra atores recalcitrantes ao processo de cumprimento e aplicação de suas reivindicações de direitos. Nesses casos, o uso dos mecanismos legais ocorre para atrair e "forçar a atenção para as demandas do movimento e para compelir pelo menos algumas concessões de políticas (...) de funcionários estatais ou outros atores poderosos" (MCCANN, 1998, p. 92). Desse modo, os ativistas utilizam táticas legais e o recurso ao litígio como uma estratégia de pressão, num esforço de gerar ação responsiva do Estado.

A alavancagem legal importa, ademais, durante a aplicação de políticas, quando os ativistas buscam fazer com que a aceitação formal de novos direitos e normas se traduza de fato em mudanças de práticas substantivas, pressionando o Estado a levar em conta as medidas preconizadas pelo processo jurídico-legal decorrente do litígio ao longo de processo de tomada de decisões e implementação de políticas. Nesse sentido, "táticas legais - e em especial litígio de fato ou a sua ameaça - podem ajudar os ativistas do movimento a ganhar voz, posição e influência no processo de reforma e implementação de políticas" (MCCANN, 2006, p. 32). Isso porque os movimentos utilizam tais ferramentas para obter acesso institucional formal às instâncias do Estado, na expectativa de que sua pressão e vigilância possam contribuir, entre outros objetivos, para formalizar e padronizar os processos de formulação e implementação de políticas em acordo com as normas 
que embasam suas demandas de direitos, opondo-se, portanto, dessa forma, a modos discricionários e insulares de tomada de decisão (ibidem, p. 33).

Kay (2011), por sua vez, argumenta também que leis e mecanismos adjudicatórios favoráveis abrem uma janela de oportunidade para que os ativistas invoquem proteções legais e reparações às suas queixas. Como consequência, eles podem se transformar em importantes sinais para os movimentos sociais, encorajandoos não só a mobilizar o direito e a utilizar estratégias de litígio, mas também a usar outras estratégias para impulsionar seus objetivos e aumentar as chances de sucesso de suas ações e táticas de mobilização. Segundo a autora, “Litígio bemsucedido pode fortalecer os movimentos ao aumentar seu moral, enfraquecer a oposição e conceder legitimidade às reivindicações de direitos” (KAY, 2011, p. 422), concedendo aos ativistas ferramentas de pressão mais institucionalizadas frente aos seus alvos, o que aumenta as chances de obtenção de mudanças de políticas e justifica o tempo e recursos gastos pelo movimento com as dispendiosas estratégias de mobilização do direito.

Por fim, Simmons também reconhece a importância da dimensão instrumental das táticas legais ao frisar que o regime e as normas internacionais de direitos humanos oferecem um espaço e recursos para que atores e grupos domésticos litiguem contra o seu próprio Estado no plano local, tendo por fundamento os direitos reconhecidos nos tratados (SIMMONS, 2009, p. 129-35; 150). As obrigações legais internacionais contraídas podem converter-se, desse modo, em um importante componente do direito doméstico, i.e., podem transformar-se em obrigações legais executáveis no plano interno, a partir das quais demandas de atores sociais e decisões judiciais podem se basear, o que oferece, portanto, por um lado, novas ferramentas de litígio para indivíduos e grupos nos tribunais locais, e, por outro, novos recursos jurídico-legais para que atores judiciais progressistas interessados na aplicação do direito internacional possam fortalecer sua posição institucional e superar as resistências encontradas ao avanço das suas agendas pró direitos humanos.

Todavia, o litígio é uma possível estratégia política aplicável não só a casos emblemáticos e representativos ou à construção de uma jurisprudência nacional pró-direitos humanos. Seus resultados judiciais podem também reverberar na revisão de regras e leis, além de dar visibilidade às ações e às causas antes invisibilizadas de ONGs e movimentos sociais (ibidem, p. 132). Ademais, o litígio contribui ainda para reenquadrar demandas políticas que, a princípio, 
são específicas e particulares dentro do marco mais universalista e legitimador oferecido pela linguagem dos direitos humanos, potencialmente alterando como as questões são concebidas, expressadas e discutidas (ibidem, p. 134).

\section{O balanço do caso da guerrilha do Araguaia}

\section{Reconhecimento da vitória}

Dentro do grupo de familiares mais ativos no acompanhamento do caso Gomes Lund, o balanço sobre o litígio no SIDH reflete, ao mesmo tempo, tanto o reconhecimento dos efeitos e da importância da sentença condenatória da CoIDH como avaliações críticas sobre as limitações dessa vitória, apontando assim para as potencialidades e entraves das decisões do SIDH, de modo geral. Apesar do grande valor atribuído a essa conquista, do papel que ela passa a ocupar como eixo central de reivindicação desse grupo e do seu claro impacto, não só para a agenda de demandas dos familiares, mas também para o sentimento de empoderamento pessoal desses militantes, prevalece a frustração com a falta de resultados da condenação internacional, que, aliás, reforça o histórico de atuação política dessa agrupação, já acostumada com a irresponsividade do Estado frente aos temas da verdade e justiça ${ }^{6}$. A respeito dessa ambivalência perante o SIDH, de maneira emblemática, Laura Petit da Silva afirma que "a gente tem a sentença, tipo assim, ganhou, mas não levou, porque até agora, sabe, você [diz] 'ah, ganhei na loteria! Mas e o prêmio?'” (Laura Petit da Silva, 2014).

De início, no que se refere às consequências e impactos positivos da sentença condenatória da CoIDH para o movimento de familiares de mortos e desaparecidos políticos da ditadura militar, a decisão é responsável por efeitos político-estratégicos, simbólico-subjetivos e tático-instrumentais, os quais fortalecem o grupo, suas reivindicações e seus membros. Em primeiro lugar, do ponto de vista das implicações macropolíticas, a decisão impulsiona respostas internas de atores como MPF, contrário à agenda da persecução penal individual até 2011, agregando novas fontes de apoio político e oferecendo novos recursos

\footnotetext{
6 Apesar do pagamento de reparações, o Estado se nega a revelar os arquivos e informações sobre as campanhas militares contra a guerrilha do Araguaia. Os familiares das vítimas ainda buscam os restos mortais dos mortos e desaparecidos políticos e nenhum agente estatal responsável pelos crimes cometidos contra a humanidade foi processado e punido penalmente.
} 
jurídico-legais a serem utilizados em litígios domésticos nos tribunais nacionais brasileiros em casos de processos criminais contra agentes estatais da ditadura militar. Dessa forma, tal como esperado pelas perspectivas sócio-legais sobre a mobilização do direito, não apenas a agenda nacional de políticas e as decisões legais domésticas são afetadas, mas também cresce a reverberação e chance de sucesso das demandas dos familiares. Frente à obrigação expressa de investigar, processar e punir do SIDH, uma minoria de procuradores federais progressistas do MPF tem encontrado na sentença Gomes Lund ferramentas que os legitimaram a reabrir o debate sobre a responsabilização penal, até então aparentemente interditado de maneira absoluta pela decisão do STF na ADPF 153.

Além disso, em segundo lugar, ainda do ponto de vista dos efeitos políticoestratégicos, a sentença da CoIDH faz também com que a agenda do grupo de familiares converta-se em determinação obrigatória de um tribunal internacional reconhecido pelo Estado, afastando as críticas de que se trataria apenas de um conjunto de reivindicações particulares, privadas e sectárias sobre militantes desaparecidos de classe média. Assim, por um lado, a sentença contribui para reconstruir e expandir a estrutura de oportunidades políticas dentro da qual os familiares estão inseridos, aumentando a relevância da questão no circuito políticoinstitucional doméstico e imbuindo suas queixas de legitimidade e visibilidade. Ao mesmo tempo, a sentença se converte simultaneamente não só em um ponto focal em torno do qual os familiares podem catapultar o alcance e impacto das suas reivindicações, mas também em um modelo claro, objetivo e indisputável que reúne as práticas e políticas a serem cumpridas pelo Estado, transformando-se, assim, em uma ferramenta altamente institucionalizada de pressão e resistência que ajuda a manter e fomentar a mobilização social em torno da causa.

Por outro lado, a decisão fornece ainda, em terceiro lugar, um novo enquadramento interpretativo para as demandas dos familiares. Abre-se a oportunidade de articular, por meio da mobilização do direito internacional, um retrato completo da política sistemática de violações da ditadura, assinalando suas causas e sinalizando claramente as responsabilidades do Estado e os caminhos a serem seguidos em termos de verdade, justiça e medidas de não repetição, o que abala profundamente o enquadramento jurídico prevalecente no Brasil sobre os efeitos e alcances da Lei de Anistia. Isso reposiciona o caso específico da guerrilha do Araguaia dentro de uma narrativa mais abrangente que condena, para além desse episódio, todas as violações de direitos humanos perpetradas pela ditadura, assinalando os abusos cometidos contra o conjunto da sociedade 
brasileira naquele período. Consequentemente, lança-se luz sobre a negligenciada agenda da justiça e se afasta a estigmatização histórica sofrida pelos familiares e vítimas, tradicionalmente representados como comunistas antipatrióticos. Logo, constrangem-se as possibilidades discursivas do Estado, com especial atenção para a reiterada noção da anistia eivada de impunidade como pacto fundacional da redemocratização e da retomada do Estado de Direito.

Na avaliação de Amélia Teles e Togo Meirelles, a sentença da Corte constitui uma grande vitória de enorme significação política, responsável pelo embasamento da atuação mais recente do MPF frente aos crimes do regime militar, impulsionando, dessa maneira, novas e inéditas respostas de atores internos. As tipificações, argumentos e categorias legais presentes na sentença, combinados com a pressão social do movimento de familiares, formariam, assim, nas suas leituras, a base que tem impulsionado as respostas domésticas de vários procuradores (Maria Amélia de Almeida Teles, 24 set. 2014; Togo Meirelles, 2014).

Ademais, ainda no tocante às consequências macropolíticas, a condenação serve ainda de ferramenta política a outros movimentos sociais que podem se valer não só dos dispositivos da sentença, mas também do exemplo e experiência acumulada dos familiares de mortos e desaparecidos políticos frente ao SIDH para confrontar as muitas arbitrariedades do Estado que ainda persistem impunemente. Na opinião de Criméia Schmidt de Almeida, a vitória no SIDH contribui para

as pessoas perceberem que elas têm direitos, não é? Então você pega, por exemplo, as mães de maio de 2006 [mães e familiares de centenas de jovens desaparecidos de maneira forçada e executados extrajudicialmente pela Polícia Militar do Estado de São Paulo em maio de 2006, em retaliação a ataques de uma organização criminosa, o Primeiro Comando da Capital], elas não levaram tanto tempo quanto a gente. Certo? Elas já encontraram um caminhozinho andado. Já encontraram, está certo, alguém que disse, “olha, por ali dá. Já trilharam aquele caminho". (Criméia Alice Schmidt de Almeida, 23 set. 2014)

Além disso, por mais que a sentença não seja cumprida, tanto o silêncio sobre o passado quanto o discurso oficial de que o Estado já tomou todas as medidas possíveis no tocante à justiça de transição foram irremediavelmente abalados. Novamente segundo Criméia, põe-se fim em definitivo à mitologia do acordo fundador da Nova República, supostamente celebrado por meio da Lei de Anistia, e "essa sentença vai pra história do Brasil. Então nós não vamos ter uma 
história tão bonitinha como se costuma contar a história, né? Nós não vamos ter lei áurea aqui, coisinhas do gênero" (Criméia Alice Schmidt de Almeida, 23 set. 2014). De igual maneira, as demandas dos familiares ganham a chancela da CoIDH e adquirem uma nova dimensão política e jurídica, impulsionando novas estratégias de resistência institucional. Nas palavras de Elizabeth Silveira, "Não sou eu mais que estou falando, agora quem está falando é a justiça internacional. O Brasil não é signatário, não assinou?” (Elizabeth Silveira, 2014).

Por sua vez, finalmente no que tange ao impacto da decisão da perspectiva mais subjetiva e simbólica das vítimas, é consensual entre os familiares o sentimento de empoderamento pessoal e político e a sensação de finalmente poder afastar os estigmas, preconceitos e ter os seus direitos reconhecidos, demonstrando assim a justeza da luta política empreendida há mais de quatro décadas. A sentença fortalece as reivindicações históricas do movimento e contribui para a construção social, política e simbólica dos familiares enquanto portadores legítimos de direitos que merecem reconhecimento público oficial. Para Amélia Teles, como resultado desse processo, "você cresce, você se sente orgulhosa, você é protagonista de uma história” (Maria Amélia de Almeida Teles, 24 set. 2014).

Para Lorena Moroni, a condenação proporciona um alívio, ao provar que os familiares sempre estiveram certos e que os militares violadores de direitos humanos nunca defenderam a pátria (Lorena Moroni, 2014). Ainda a esse respeito, Laura Petit oferece o relato mais bem-acabado de como o julgamento na CoIDH, por si só, representa uma forma de reparação moral e de reconhecimento:

Quando eu fui lá, eu pude contar toda minha história, foi assim, "pela primeira vez estou podendo falar e ser considerada uma cidadã que teve os seus direitos violados”, que meus irmãos só não eram vítimas, eu também fui considerada uma vítima, porque eu tive a minha família dizimada (...) Aqui no Brasil não me sentia uma cidadã. Lá eu me senti uma cidadã do mundo. (Laura Petit da Silva, 2014)

Assim, em suma, os familiares reconhecem a importância da condenação e a implementação da sentença passa a ocupar um papel central dentro das suas estratégias de atuação. Ao acolher todas as demandas históricas dos familiares, a decisão da CoIDH se transforma em um valioso instrumento de luta, cujo cumprimento permite não só sustentar e fortalecer a mobilização dos familiares dos guerrilheiros do Araguaia, mas também de outras vítimas do regime militar, já que a abrangência das suas determinações, referidas a todas as graves violações 
de direitos humanos da ditadura, abre considerável espaço para construir alianças com outros grupos afetados (Criméia Alice Schmidt de Almeida, 12 set. 2014), expandindo a estrutura de oportunidades políticas e a coalizão de atores prócumprimento. Dessa forma, a luta travada pelos parentes das vítimas da guerrilha do Araguaia repercute sobre todos os outros casos da ditadura, permitindo inclusive que o MPF, com base na sentença, tente reverter, na nova ADPF 3207, ainda em tramitação, a interpretação firmada na ADPF 153.

Nesse sentido, o impacto da sentença é tão relevante que até mesmo as palavras de ordem das militantes passam a fazer menção expressa à decisão da CoIDH e à necessidade imperiosa de seu cumprimento, revelando assim a centralidade adquirida por esse diploma legal como um dos novos eixos norteadores do movimento de familiares. Como resultado dessa conquista, Victoria Grabois relata ter passado por um processo de aprendizado e reavaliação a respeito das potencialidades da mobilização do direito. Se antes a via jurídico-legal era vista com desconfianças, após a condenação ela passou a compreender a possibilidade de explorar e aproveitar todas as pequenas brechas e interstícios existentes dentro dessa estrutura de sustentação do Estado burguês. A esse respeito, a militante frisa que

apesar que a OEA é um órgão do imperialismo e que sempre serviu ao capital, hoje em dia eu acho que a gente tem que usar todos os meios que a gente precisa. Naquela época [em 1995] eu não tinha essa visão (...) Então eu era contra isso [enviar o caso para a CIDH], porque eu era [radical]. Agora, depois que eles deram a sentença favorável, aí eu achei que tudo que foi feito foi correto, que a minha posição era uma posição sectária (...) o Direito foi feito para você consolidar o Estado burguês, o Estado capitalista. E tem brechas, né? Você sempre encontra uma brechinha no Direito. (Victoria Grabois, 2014)

\section{Frustração com os obstáculos e a falta de resultados}

Já no que tange às críticas dirigidas às limitações do SIDH, os familiares se queixam da legalização e judicialização excessivas do sistema ${ }^{8}$, as quais se

7 Apresentada ao STF pelo Partido Socialismo e Liberdade (PSOL), em maio de 2014, a ADPF 320 gira em torno da sentença condenatória da CoIDH e do descumprimento da Convenção Americana de Direitos Humanos pelo Brasil, requerendo que a Lei de Anistia deixe de ser utilizada como uma barreira face aos esforços de persecução penal.

8 O processo crescente de judicialização e legalização do SIDH nas últimas duas décadas se refere sobretudo às práticas e procedimentos da $\mathrm{CIDH}$, que tem progressivamente tratado as denúncias e queixas recebidas como um processo judicial cada vez mais exigente em termos de apresentação de evidências e argumentos jurídico-legais, “moldados no domínio de advogados que se especializam em litígio” (DULITZKY, 2011, p. 143). 
constituem em barreiras para a sua ativação, demandando assim a necessidade de intermediação e tradução por parte de uma organização não governamental (ONG) de direitos humanos especializada e com uma equipe de advogados altamente treinada. Ao considerar a trajetória do caso Gomes Lund, é consensual entre os familiares a importância do trabalho do CEJIL e a avaliação de que seu papel foi imprescindível para o andamento e conclusão bem-sucedida do litígio.

A impossibilidade de realizar um acompanhamento sistemático do caso, a falta de treinamento jurídico e de recursos para arcar com as despesas de deslocamento para as sessões da CIDH e CoIDH, bem como o desconhecimento a respeito das regras informais de funcionamento do SIDH, são frequentemente apontados pelos familiares como fatores que dificultam o acesso ao mecanismo regional de direitos humanos, tornando necessária a parceria com uma ONG litigante especializada e com um perfil especificamente voltado para a ativação do SIDH. Assim, Laura Petit afirma que “o CEJIL, ele está equipado, ele tem as ferramentas, tem o conhecimento do funcionamento do sistema interamericano, e ele foi quem possibilitou essa via de acesso também” (Laura Petit da Silva, 2014).

Refletindo mais detidamente sobre a questão dos custos e da necessidade de um conhecimento jurídico altamente especializado, capaz de compreender todos os intrincados caminhos de processamento dos casos, Elizabeth Silveira afirma que

como que a gente ia [acompanhar]? Porque é custoso, é caro (...) não é qualquer advogado, é um advogado que tenha esse perfil (...) Tem também a sua política interna que você tem que estar lá dentro pra saber, entender, movimentar, quem você vai falar, quem você procura, quem é o juiz que é assim, quem é o secretário (...) Se agora eu peço um relatório, se agora eu peço uma audiência, se eu não peço. (Elizabeth Silveira, 2014)

Por sua vez, para Amélia Teles, para além da questão dos altos custos e da falta de preparo, o problema é antes a necessidade de intermediação e tradução frente aos códigos e questões jurídicas manejados pelo SIDH, os quais constituem uma barreira intransponível para os familiares. Frente aos meandros legais, burocráticos e linguísticos do SIDH, torna-se indispensável a presença de um intérprete, como o CEJIL, a fim de que os trâmites e exigências para o andamento do caso sejam inteligíveis para os familiares. Para a militante,

[Sem o CEJIL] Não é possível, porque você tem que acompanhar aquilo todo dia. É igual a justiça. Ela é tão ruim, que se você não tiver um profissional intermediário, ela não funciona. Você não entende o que eles estão falando, 
eles estão em Washington, estão lá na Costa Rica, você não tem condição. Não tem nem saúde, porque tem horas que eles te perguntam coisas que pra você, na sua compreensão simples da coisa, você já respondeu desde o primeiro dia. (Maria Amélia de Almeida Teles, 29 ago. 2014)

De forma mais geral, a necessidade de tradução e acompanhamento pelo CEJIL reflete também outras limitações e aspectos criticáveis do sistema interamericano, os quais ajudam a compor o quadro de ambivalência dos familiares frente ao resultado do litígio. A despeito do reconhecimento do efeito de empoderamento pessoal e das dinâmicas político-jurídicas desatadas pela sentença, são comuns as críticas sobre a demora injustificável, dificuldade de acesso, altos custos, desgaste com as exigências burocrático-processuais e falta de meios para obrigar o Estado a cumprir as sentenças da CoIDH.

Sobre a demora do sistema interamericano, não só no que se refere ao trâmite do caso da guerrilha do Araguaia, mas também no que diz respeito à sua ausência e negligência durante a ditadura militar, Criméia considera que o SIDH é um instrumento útil de pressão, mas pouco ágil, tendo sido incapaz de garantir a defesa dos direitos humanos justamente quando, no auge do regime militar, mais se havia necessitado da atuação da CIDH. Desse modo, "se a gente entrou [com o caso] porque o Brasil não tinha vontade de fazer justiça, a Comissão [Interamericana] também não teve tanto empenho" (Criméia Alice Schmidt de Almeida, 12 set. 2014) ${ }^{9}$. Como resultado,

[o sistema interamericano] é uma ferramenta difícil de ser usada (...) Ah, por todo esse processo. Você tem que fazer uma ação aqui. É cheia de teretetê, né? Não é uma ferramenta ágil. Porque eu acho que a questão dos direitos humanos, você tem que defender no momento que ele está sendo desrespeitado. Se for defender direitos humanos de defunto há mais de quarenta anos atrás, é pouco. (Criméia Alice Schmidt de Almeida, 23 set. 2014)

No que tange à dificuldade de acesso e aos altos custos decorrentes da tramitação do caso, Criméia considera que "É difícil recorrer, porque envolve [deslocamento]. Só por correspondência você não resolve. Então envolve a ida física a esses lugares, isso é dispendioso, não é fácil. (...) Então eu acho que por isso não se recorre mais” (Criméia Alice Schmidt de Almeida, 23 set. 2014). A respeito da inexistência de mecanismos efetivos que forcem o Estado a

9 A petição foi apresentada em 1995 e somente em 2008, depois de ter admitido o caso em 2001, é que a CIDH emitiu um relatório de mérito e logo em seguida enviou o caso para a CoIDH. 
implementar a sentença, Elizabeth Silveira reconhece, quase que de maneira resignada, que “a Corte [Interamericana] (...) não tem poder de (...- sanção. Não existe nenhuma sanção para o país. Se ele [o país] não fizer, vai ficar feio [para o país]. Mas tipo, não fez. 'Ah, ficou feio’. Dou de ombro” (Elizabeth Silveira, 2014).

Em meio a esse cenário, no qual não se pode compelir o Estado a cumprir a decisão, à CoIDH não resta alternativa senão aguardar que as autoridades brasileiras honrem suas obrigações internacionais. Para Criméia, isso equivale ao ato pelo qual Pôncio Pilatos lavou suas mãos frente à crucificação de Jesus Cristo, uma vez que

estão investindo na morte dos réus, porque aí não precisa julgar (...) tanto a Corte aguarda, como o Estado brasileiro aguarda (...) dá uma de Pilatos (...) Porque senão seriam mais (...) enfáticos, e [haveria] mais coisa nos relatórios de cumprimento. (Criméia Alice Schmidt de Almeida, 23 set. 2014)

Por seu turno, para Amélia Teles, num processo já demasiadamente lento, longo e complexo, permeado por altos custos e incertezas quanto ao seu resultado final, o SIDH aloca uma carga desumana de exigências provatórias, burocráticas e processuais para as vítimas, as quais são expostas a um desgaste desnecessário que deveria ser, em sua opinião, de responsabilidade dos operadores da CIDH e da CoIDH e não daqueles que já sofreram violações de direitos humanos e se encontram muitas vezes em situação de vulnerabilidade. Nas suas palavras,

[O que] eles exigem das entidades, das pessoas é desumano. Eu acho desumano. Exigir aquelas perguntas e respostas [...] Eles podiam mandar um especialista vir [fazer] um resumo, relatório”. (Maria Amélia de Almeida Teles, 24 set. 2014)

Por fim, alguns familiares queixam-se de que, para serem ouvidos pelo SIDH e em outros espaços institucionais, domésticos e internacionais, tiveram de moderar o teor de suas críticas e adotar uma nova identidade de ativistas de direitos humanos, em detrimento da sua postura de militância política mais contestatória. Face ao predomínio crescente dos direitos humanos tanto sobre outras narrativas rivais de dissenso quanto sobre projetos e visões alternativos que buscam obter legitimidade política (BEITZ, 2009; HAFNER-BURTON; RON, 2009, p. 393), a adoção desse discurso se converteu em pré-requisito para que os familiares fossem ouvidos e pudessem vislumbrar alguma chance, ainda que mínima, de impacto na agenda pública, o que exerce, desse modo, um papel de constrangimento sobre a atuação e perfil das atividades desses grupos. 
A esse respeito, Victoria Grabois, presidente do GTNM-RJ, familiar de três desaparecidos da guerrilha do Araguaia e detentora de uma formação política comunista, demonstra em seu relato dificuldade para "digerir essa linguagem dos direitos humanos" (Victoria Grabois, 2014) que, na sua avaliação, teria sido imposta aos familiares como decorrência da sua própria luta política e do cálculo de que, para ter alguma influência, era preciso incorporar essa narrativa específica em detrimento de outras plataformas políticas. Nas suas palavras,

eu acho muito engraçado quando eu sou apresentada como uma defensora dos direitos humanos. Às vezes eu tenho vontade de rir (...) porque nos empurraram pra isso (...) isso [ser caracterizada como defensora dos direitos humanos] é contra, totalmente, os meus princípios. Mas essa luta me levou a [...] ser "defensora dos direitos humanos" (...) A gente é recebida porque a gente é “defensor dos direitos humanos”. O grupo Tortura Nunca Mais é "defensor dos direitos humanos”. (Victoria Grabois, 2014)

Essas críticas e considerações revelam assim um efeito potencialmente perverso não só do SIDH, mas de todo o regime internacional de direitos humanos. Para que suas causas e demandas ganhem visibilidade e legitimidade, vítimas e grupos vulneráveis precisam incorporar a linguagem, as categorias jurídico-legais e as normas e práticas institucionais de registro das violações e de produção de informações oriundas do regime internacional de direitos humanos, aceitas como "neutras", críveis, verificáveis e reproduzíveis pelas organizações intergovernamentais, grandes ONGs internacionais, audiências externas e organismos doadores. Por conseguinte, como resultado desses constrangimentos, são abandonadas as narrativas de dissenso mais totalizantes, radicais e contestatórias do passado, em favor de um marco mais liberal e minimalista atrelado à lógica de mudanças incrementais. Para que possam conquistar audiências domésticas e internacionais, movimentos políticos antes calcados em um tipo de ação política mais transformadora, contestatória, de resistência e de ruptura deslocam-se consequentemente para um lugar normatizado, marcado pelo ativismo profissional desapaixonado e de forte adesão ao universo jurídico-legal dos escritórios de advocacia. Mudanças substantivas e radicais das estruturas sociais não são o alvo prioritário dos direitos humanos, e embora seja clara a necessidade de instrumentalizar essa abordagem como uma ferramenta política, muitos familiares não se contentam apenas com essa linguagem, uma vez que se trata de "muito pouco para quem queria muito" (Elizabeth Silveira, 2014). 


\section{Concusões}

A mobilização dos recursos jurídico-legais da sentença da CoIDH no caso Gomes Lund como ferramenta política contestatória gerou um ponto focal em torno do qual familiares, CEJIL e MPF continuam a pressionar o Estado a despeito dos enormes obstáculos contrários à consecução da agenda de justiça de transição no Brasil. A despeito de todas as críticas realizadas pelos familiares dos mortos e desaparecidos políticos na guerrilha do Araguaia, as quais apontam para importantes limitações e problemas da atuação do SIDH, é inegável que a sentença condenatória da CoIDH se constitui em um dos poucos caminhos ainda abertos no Brasil para que inúmeras vítimas das atrocidades dos crimes de lesahumanidade possam confrontar o Estado e lutar em favor de verdade, justiça, reparações e medidas de não repetição, instrumentalizando assim a normatividade internacional para empoderar e fortalecer suas reivindicações de direitos diante de um contexto nacional cujas barreiras legais e políticas têm impedido qualquer forma de avanço das suas demandas.

Desse modo, de acordo com as perspectivas dos familiares mais envolvidos com o processo de litígio, e tal como teorizado pela literatura sócio-legal, os efeitos positivos da atuação do SIDH - empoderamento pessoal e político das vítimas; reconstrução e expansão da estrutura de oportunidades políticas dentro da qual os familiares das vítimas estão inseridos; criação de novos recursos de litígio contra o Estado; oferta de novos enquadramentos interpretativos para as queixas dos familiares; e canalização da sentença da CoIDH como ferramenta política para outros movimentos sociais - superam em muito os seus efeitos negativos ou aspectos criticáveis, tais como a legalização e judicialização excessivas, necessidade de intermediação e tradução por meio de ONGs especializadas, moderação do teor das demandas das vítimas, demora injustificável, dificuldade de acesso, altos custos, imposição de exigências burocrático-processuais às vítimas e falta de mecanismos de enforcement.

Ainda assim, vale ressaltar esses efeitos potencialmente limitadores da mobilização do direito sobre a prática política de atores e movimentos sociais. Embora eles não tenham superado os ganhos simbólico-ideacionais, políticoestratégicos e tático-legais no caso específico da mobilização legal referente ao caso da guerrilha do Araguaia, não necessariamente esse será o resultado em outros contextos de ativismo sociopolítico, uma vez que o discurso normativo-jurídico pode impor constrangimentos e gerar embaraços à linguagem e às estratégias 
contestatórias desses sujeitos políticos. Tal aspecto não tem recebido devida atenção nos trabalhos mais recentes sobre ativismo transnacional e impacto doméstico de normas internacionais de direitos humanos e merece análise mais cuidadosa.

Em outras palavras, a mobilização sócio-legal do direito internacional dos direitos humanos abre espaço para trazer à tona e legitimar interesses e reivindicações de grupos marginalizados, contribuindo para o processo de constituição desses atores políticos. Porém, os limites inerentes à linguagem incremental dos direitos humanos e à sua dimensão burocrático-legal - marcada pelo alto custo de entrada, complexidade e lenta temporalidade de cumprimento de ritos procedimentais - chocam-se com a urgência da dor e da perda, com o clamor de justiça e com a radicalidade das demandas das vítimas. As tensões entre essas duas almas da mobilização do direito, ora de voz pública ${ }^{10}$ e fomentadora da ação coletiva, ora de limitadora do ativismo político, não podem ser ignoradas. Elas se apresentarão empiricamente, em casos específicos, de maneiras diferentes, a depender de distintos circuitos possíveis de intermediação político-legal que conectam atores e movimentos sociais ao regime internacional de direitos humanos por meio de ONGs ou outros grupos. Falta-nos clareza sobre a topografia desses circuitos que podem fazer o pêndulo se orientar para uma mobilização sócio-legal mais tecnocrático-legalista ou transformadora e contestatória, o que exige uma agenda de pesquisa aprofundada para desvendar tais tensões.

\section{Referências}

BEITZ, Charles R. The Idea of Human Rights. Nova Iorque: Oxford University Press, 2009. BRASIL. Constituição da República Federativa do Brasil de 1988. Emenda Constitucional No. 45, de 30 de dezembro de 2004.

http://www.planalto.gov.br/ccivil_03/constituicao/Emendas/Emc/emc45.htm (Acesso em: 26 dez. 2017)

BRASIL. Ministério Público Federal. $2^{\text {a }}$. Câmara de Coordenação e Revisão. Crimes da ditadura militar: Relatório sobre as atividades de persecução penal desenvolvidas pelo MPF em matéria de graves violações a DH cometidas por agentes do Estado durante o regime de exceção. Brasília: MPF, 2017.

10 Para uma discussão relativa ao conceito de voz pública, aplicado à atuação do Alto Comissário das Nações Unidas para os Direitos Humanos, consultar Hernandez, 2015. 
COIDH (CORTE INTERAMERICANA DE DIREITOS HUMANOS). Caso Gomes Lund y otros (Guerrilha do Araguaia) vs. Brasil. Exceções preliminares, mérito, reparações e custos. Sentença de 24 nov., série C, n. 219, 2010.

COIDH (CORTE INTERAMERICANA DE DIREITOS HUMANOS). Resolución de la Corte Interamericana de Derechos Humanos de 17 de octubre de 2014. Caso Gomes Lund y otros ("Guerrilha do Araguaia”) vs. Brasil. Supervisión de Cumplimiento de Sentencia. DULITZKY, Ariel. The Inter-American Human Rights System Fifty Years Later: Time for Changes. Quebec Journal of International Law, Special Edition, 2011.

HAFNER-BURTON, Emilie; RON, James. Seeing double: human rights impact through qualitative and quantitative eyes. World Politics, vol. 61, n. 2, 2009. https://muse. jhu.edu/article/262181/pdf (acesso: 26 dez. 2017).

HERNANDEZ, Matheus de Carvalho. O Alto Comissário das Nações Unidas para os Direitos Humanos e seu Escritório: criação e desenvolvimento institucional (1994-2014). Tese (Doutorado em Ciência Política), Universidade de Campinas, Campinas, 2015. KAY, Tamara. Legal Transnationalism: The Relationship between Transnational Social Movement Building and International Law. Law \& Social Inquiry, vol. 36, n. 2, pp. 419-454, spring, 2011.http://scholar.harvard.edu/files/tamarakay/files/kay_ 1si_2011.pdf (acesso: 26 dez. 2017)

MCCANN, Michael. Rights at work: pay equity reform and the politics of legal mobilization. Chicago, University of Chicago Press, 1994.

MCCANN, Michael. How does Law Matter for social movements? In: GARTH, Bryant; SARAT, Austin t (eds.), How does Law Matter?. Illinois, Northwestern University Press, 1998.

MCCANN, Michael. Law and social movements: contemporary perspectives. Annual Review of Law and Social Science, vol. 2, p. 17-38, 2006. https://doi.org/10.1146/ annurev.lawsocsci.2.081805.105917 (acesso: 26 dez. 2017).

MCCANN, Michael. Poder Judiciário e mobilização do direito: uma perspectiva dos “usuários”. Anais do Seminário Nacional sobre Justiça Constitucional. Seção Especial da Revista Escola da Magistratura Regional Federal da 2a . Região/Emarf, pp. 175-196, 2010.

RAMANZINI, Isabela Gerbelli Garbin. Supremo Tribunal Federal: equilíbrio entre a Constituição e os Tratados Internacionais. Boletim Meridiano 47, vol. 15, n. 141, p. 44-50, jan.-fev., 2014. http://periodicos.unb.br/index.php/MED/article/view/ 9873/7623 (acesso: 26 dez. 2017).

SIKKINK, Kathryn. Patterns of Dynamic Multilevel Governance and the Insider-Outsider Coalition. In: DELLA PORTA, Donatella; TARROW, Sidney (eds.). Transnational Protest and Global Activism, New York: Rowman and Littlefield, pp. 151-173, 2005. SIMMONS, Beth A. Mobilizing for Human Rights: International Law in Domestic Politics. Nova Iorque: Cambridge University Press, 2009. 


\section{Entrevistas realizadas}

1) ALMEIDA, Criméia Alice Schmidt de. Entrevistas: Criméia Alice Schmidt de Almeida. Ex-guerrilheira, familiar de desaparecidos políticos na guerrilha do Araguaia e militante da CFMDP. Entrevistas concedidas a Bruno Boti Bernardi em São Paulo, em 12 de setembro de 2014 e 23 de setembro de 2014.

2) SILVEIRA, Elizabeth. Entrevista: Elizabeth Silveira. Militante do GTNM-RJ e irmã de desaparecido político na guerrilha do Araguaia. Entrevista concedida a Bruno Boti Bernardi no Rio de Janeiro, em 21 de outubro de 2014.

3) SILVA, Laura Petit da. Entrevista: Laura Petit da Silva. Familiar de desaparecidos políticos na guerrilha do Araguaia. Entrevista concedida a Bruno Boti Bernardi em São Paulo, em 30 de outubro de 2014.

4) MORONI, Lorena. Entrevista: Lorena Moroni. Familiar de desaparecida política na guerrilha do Araguaia. Entrevista concedida a Bruno Boti Bernardi no Rio de Janeiro, em 23 de outubro de 2014.

5) TELES, Maria Amélia de Almeida. Entrevistas: Maria Amélia de Almeida Teles. Ex-presa política e militante da CFMDP. Entrevistas concedidas a Bruno Boti Bernardi em São Paulo, em 29 de agosto de 2014 e 24 de setembro de 2014.

6) MEIRELLES, Togo. Entrevista: Togo Meirelles. Ex-vice-presidente do GTNM-RJ. Entrevista concedida a Bruno Boti Bernardi via Skype em 26 de setembro de 2014.

7) GRABOIS, Victoria. Entrevista: Victoria Grabois. Presidente do GTNM-RJ e familiar de desaparecidos políticos na guerrilha do Araguaia. Entrevista concedida a Bruno Boti Bernardi no Rio de Janeiro, em 23 de outubro de 2014. 


\title{
Temas de Relações Internacionais nos discursos de posse de presidentes e de chanceleres brasileiros $(1995-2017)^{1}$
}

\author{
Issues of International Relations in inauguration \\ speeches of brazilian presidents and chancellors \\ (1995-2017)
}

DOI: $10.21530 /$ ci.v12n3.2017.707

Felipe Ferreira de Oliveira Rocha²

\section{Resumo}

O artigo investiga as ênfases temáticas de presidentes e de chanceleres brasileiros durante os seus pronunciamentos de posse. O objetivo principal é saber se tais atores políticos tenderam a manter um padrão de continuidade no que tange à priorização de temas e categorias ou se os mesmos tendem a minimizar e maximizar citações de forma específica e particular. Para verificar isso, técnicas de análise de conteúdo e de mineração textual foram empregadas. Através delas, constatou-se a existência de uma continuidade, no sentido de que há categorias que são constantes na sua insignificância, independente do ator. Há também categorias que, via de regra, são mencionadas repetidamente em todos os pronunciamentos. Ademais, ao considerar medidas associativas e de distâncias de palavras, foi possível agrupar os atores em níveis de proximidade. Nesse aspecto, é visível um agrupamento muito coeso entre os chanceleres, ao passo que os presidentes tendem a se localizar de forma mais esparsa.

Palavras-chave: Agenda de Políticas; Diplomacia Presidencial; Ministro de Relações Exteriores, Política Externa Brasileira; Análise de Conteúdo.

\section{Abstract}

In this paper, I question the thematic emphasis of Brazilian Presidents and Chancellors during their inauguration speeches. The main objective is to know if the actors maintain a pattern of continuity when it comes to the prioritization of topics and categories or if they tend to

1 O presente trabalho foi realizado com apoio do CNPq, Conselho Nacional de Desenvolvimento Científico e Tecnológico - Brasil.

2 Programa de Pós-Graduação em Ciência Política pela Universidade Federal de Pernambuco (UFPE), em Recife/PE, Brasil. E-mail: rocha.felipeferreira@gmail.com

Artigo submetido em 12/09/2017 e aceito em 11/12/2017. 
minimize and to maximize mentions in a particular way. By means of Content Analysis and Text Mining, it was found a continuity in the sense that there are insignificant categories, regardless of the actor. There are also categories maintained repetitively important in every speech. Besides, when measures of associations and distance of words had been used, it was found clusters of actors in different levels of proximity. In this aspect, it is conspicuous the existence of a cohesive cluster between Chancellors, whereas Presidents tend to be in a sparser localization.

Keywords: Political Agenda; Presidential Diplomacy; Brazilian Chancellors, Brazilian Foreign Policy; Content Analysis.

\section{Introdução}

Durante muito tempo, a mudança em processos políticos foi debatida a partir de dois ângulos: o incremental e o racional. Enquanto o primeiro entende que as alterações de políticas públicas resultam de variações sobre o passado, no sentido em que há uma tendência de continuidade, de conservadorismo e de inércia em relação ao status quo, o segundo afirma que, a cada nova gestão, há novos contextos e novos cálculos decisórios que fazem com que as modificações sejam radicais (SOUZA, 2006; DYE, 2010).

Entretanto, True, Jones e Baumgartner (2006) sinalizaram uma terceira possibilidade, a do equilíbrio pontuado (punctuated-equilibrium), que trata da existência de alterações incrementais no subsistema como regra e a ocorrência de mudanças radicais que acontecem na macroestrutura de forma pontual, sorrateira e dependente da visibilidade que determinados eventos passam a ter em círculos políticos, midiáticos e sociais (BAUMGARTNER et al. 2009). A partir de então, monitorar a inclusão, a priorização, a redução e a eliminação de pautas temáticas na agenda de atores políticos se tornou essencial para explicar como questões transbordam de instâncias decisórias rotineiras para estruturas macropolíticas, a ponto de romper a inércia e provocar alterações radicais do status quo.

Essa tem sido uma corrente de pesquisa basilar para a compreensão de temas relacionados a políticas públicas. Apesar disso, estudos dessa natureza são raros na academia brasileira e se tornam ainda mais rarefeitos quando se trata da relação entre a agenda de políticas do presidente da República e a do seu ministro de Relações Exteriores (ou chanceler), já que, apenas recentemente, a política externa brasileira (PEB) passou a ser considerada analiticamente como política pública (MILANI, PINHEIRO, 2013; FARIAS, RAMANZINI JÚNIOR, 2015). 
Para minimizar tal lacuna, esse artigo faz uma comparação da agenda dos dois atores supramencionados em um momento temporal específico, o de posse dos mesmos. O que Fernando Henrique Cardoso, Luiz Inácio Lula da Silva, Dilma Rousseff e Michel Temer disseram ao serem empossados foi comparado com o que os seus respectivos chanceleres disseram também ao serem empossados.

Para estruturar isso, o restante do artigo está dividido em quatro partes. A primeira traz debates teóricos sobre o papel do presidente da República e do ministro de Relações Exteriores na formulação e implementação da política externa. Os tópicos de destaque serão o insulamento burocrático do Itamaraty, a pluralização e horizontalização da PEB, bem como as possíveis relações entre a diplomacia presidencial e a diplomacia tradicional. A segunda seção é de metodologia. Nela, estão presentes todos os componentes necessários para assegurar a replicabilidade dos resultados, que são apresentados na terceira parte; e, na quarta, são feitas as conclusões.

\section{A figura do presidente da República e do chanceler na PEB}

Por ser formulada domesticamente e implementada internacionalmente, a política externa levanta calorosos debates acerca da análise de suas especificidades, sendo que duas correntes prevalecem: a dos tradicionalistas e a dos pluralistas (FIGUEIRA, 2011; MILANI, PINHEIRO, 2013).

Para os primeiros, variáveis relacionadas a correlações de forças materiais são preponderantes para o padrão de inserção e de interação dos Estados no sistema internacional, já que a estrutura se regula por uma espécie de equilíbrio de poder que impõe limites para as manobras dos entes estatais (WALT, 1985). Assim, quanto mais centralizado for o núcleo decisório, quanto mais ele for baseado em critérios técnicos e isolado de fatores políticos domésticos, mais racional será a decisão tomada. Já que se acredita que agentes com objetivos individualistas estarão impedidos de influenciar o cálculo decisório (FIGUEIRA, 2011), a política externa é tida como uma política de Estado.

Os pluralistas pensam de forma oposta. Para eles, política externa é política pública e, portanto, a análise dos tradicionalistas é, por definição, incompleta, uma vez que retira ou minimiza o peso das variáveis domésticas. A tradição pluralista tende a enfatizar a lógica do jogo de dois níveis, em que os cenários internos e externos são mobilizados para entender a tomada de decisão. Através 
desse ângulo, se originaram trabalhos sobre o papel do Executivo, do Legislativo, do Judiciário, da sociedade civil e da opinião pública na definição da política externa (PUTNAM, 1988; HOUGHTON, 2007).

Nesse ínterim, faz sentido problematizar a figura do presidente da República e de seu chanceler em assuntos internacionais. Mas, para isso, é preciso distinguir as funções constitucionalmente definidas para ambos os atores daquelas historicamente desempenhadas pelos mesmos (SATO, 2015). Nesse caso, o artigo 84 da atual Constituição serve como ponto de partida:

Compete privativamente ao Presidente da República: VII — manter relações com Estados estrangeiros e acreditar seus representantes diplomáticos; VIII - celebrar tratados, convenções e atos internacionais, sujeitos a referendo do Congresso Nacional; XIX — declarar guerra, no caso de agressão estrangeira, autorizado pelo Congresso Nacional ou referendado por ele, quando ocorrida no intervalo das sessões legislativas, e, nas mesmas condições, decretar, total ou parcialmente, a mobilização nacional; XX — celebrar a paz, autorizado ou com o referendo do Congresso Nacional; XXII — permitir, nos casos previstos em lei complementar, que forças estrangeiras transitem pelo território nacional ou nele permaneçam temporariamente (BRASIL, 2003)

Ainda na seara legal, o chanceler é o substituto direto do presidente da República, devendo colaborar no processo de formulação e execução da política externa (FIGUEIRA, 2009). Entretanto, a análise fundamentada em critérios estritamente jurídicos transmite uma realidade distorcida do processo decisório em PEB (SATO, 2015). Por isso, é preciso discutir também tópicos referentes ao insulamento burocrático do Itamaraty e à diplomacia presidencial.

O papel dos diplomatas na formulação da PEB foi historicamente constituído em paralelo com a evolução do Itamaraty no cenário administrativo do Estado nacional. Quanto mais o Ministério de Relações Exteriores (MRE) se afastava do modelo patrimonialista e se aproximava do modelo weberiano burocráticoracional $^{3}$, mais insulado, isolado e centralizado, ele ia se tornando e mais rapidamente se conformava uma coesão identitária entre os diplomatas, ampliando

3 As discussões sobre modelos ideais para representar a evolução histórica, sociológica e organizacional do Itamaraty foram feitas por Zairo Cheibub. Para o autor, pode-se dividir a cronologia de tal instituição em alguns marcos temporais. O primeiro vai de 1822 até 1902. Nesse período, chamado de patrimonialista, prevalece uma noção distorcida entre o que pertence à esfera pública e à privada, predominando relações patrimoniais e mesmo clientelistas. O segundo período coincide com a gestão do Barão do Rio Branco, quando prevaleceu uma dominação carismática e eclodiram as primeiras mudanças em direção a um terceiro modelo, o modelo burocrático-racional. Nele, foram feitas reformas administrativas para tornar a instituição técnica, racional, profissional e de excelência, pouco havendo espaço para interesses políticos privados. 
o ensimesmamento dos mesmos e a crença de que eles seriam a classe melhor preparada para identificar e guardar o interesse da nação (CHEIBUB, 1989; MOURA, 2006; FIGUEIRA, 2010).

O Itamaraty se destacou como uma ilha de excelência em meio a um oceano administrativo confuso e clientelista e, portanto, um modelo a ser seguido e que deveria sofrer poucas alterações exógenas. Ademais, tal ministério se beneficiava do fato de que a política externa não exercia, via de regra, influência decisiva no eleitor mediano. Por consequência, congressistas e presidentes tenderam a delegar seus papéis de atuação para tal instituição a fim de dedicarem tempo e talento às questões mais sensíveis e salientes nas disputas políticas (FARIA, 2012).

A nomeação de chanceleres não provenientes da carreira diplomática se tornou um desvio à regra na história de nosso presidencialismo de coalizão (ONUKI, OLIVEIRA, 2006; DINIZ, RIBEIRO, 2008; DINIZ FILHO, 2013; LOPES, FARIA, 2014). Uma das provas empíricas é apresentada por Bersch, Praça e Taylor (2017) ao compararem agências federais brasileiras e demonstrarem que o MRE é um dos órgãos cujos níveis de capacidade e de autonomia permanecem dentre os mais elevados.

A relevância da burocracia diplomática fez possível emergir linhas mestras de pensamento que asseguraram um padrão de continuidade ${ }^{4}$ em períodos autoritários e democráticos e fez com que a PEB fosse vista como sendo puramente uma política de Estado, constante e técnica (BATISTA, 2010; MIYAMOTO, 2011).

Tal espécie de consenso em relação à produção da PEB foi se desfazendo com a queda do muro de Berlim e o final da Guerra Fria, com o início da liberalização comercial e a democratização do Estado brasileiro. A partir de então, os especialistas identificaram um processo de pluralização, de politização e de horizontalização ${ }^{5}$ sobre temas internacionais com vários atores demandando envolvimento, dentre

4 A questão da mudança e da continuidade em assuntos de Política Externa é discutida tanto por tradicionais quanto por pluralistas. Desse modo, dizer que uma política é pública não significa necessariamente que, a cada nova gestão, mudanças radicais ocorrerão. Na verdade, os países têm uma margem de manobra para atuação. A grande diferença entre as duas visões é que, para tradicionalistas, as mudanças são tão pontuais e tão técnicas que não refletem de um modo significativo - são ruídos que dificilmente alteram o status quo. Já para os pluralistas, ajustes ocorrem e são relevantes, mas dificilmente revolucionários (MIYAMATO, 2011).

5 Em geral, ao falarmos em termos de horizontalização, de pluralização, de descentralização, de desencapsulamento, de democratização ou de politização estamos nos referindo ao crescimento vertiginoso de agentes e instituições interessadas em se envolver com as etapas de formulação, implementação e/ou avaliação do ciclo da política externa brasileira. Assim, esses conceitos buscam refletir a transição entre um suposto período em que era de interesse de alguns poucos falar em temas internacionais e outro período mais recente em que vários atores passaram a inserir tais temáticas como pautas de suas agendas políticas. É também importante salientar que, embora aqui tais termos sejam usados de forma intercambiada, eles não são necessariamente sinônimos. Para quem deseja obter mais informações sobre a utilização de tais termos pela literatura, recomenda-se a leitura de Farias e Ramanzini Júnior (2015). 
os quais, empresários, organizações não governamentais, órgãos do Executivo, congressistas e o próprio presidente da República (CASON, POWER, 2009; LOPES, 2011; FARIA, 2012; DINIZ FILHO, 2013; FARIA, LOPES, CASARÕES, 2013; FARIAS, RAMANZINI JÚNIOR, 2015).

No que se refere a esse último ator, cabe enfatizar que, embora alguns presidentes tenham se envolvido na esfera internacional - como Getúlio Vargas, Juscelino Kubitschek e Ernesto Geisel - , a literatura considera que ninguém antes de Fernando Henrique Cardoso exerceu, de fato, uma influência tão sistemática a ponto de ser coerente falar em diplomacia presidencial. A razão disso é que tal conceito diz respeito ao envolvimento e à condução pessoal por parte do presidente da República em projetos de política externa, de modo a extrapolar as funções protocolares definidas constitucionalmente (PRETO, 2006; DANESE, 2009; BARNABÉ, 2010; NETO, 2011; SATO, 2015; BURGES, CHAGAS BASTOS, 2017).

O ponto da questão é que, com a entrada mais assertiva do presidente no cálculo decisório da PEB, fatores pertencentes ao domínio político-eleitoral de curto prazo passaram a ser variáveis relevantes na inserção internacional do Brasil, o que levou os especialistas a questionarem a natureza da relação entre a vertente tradicional da diplomacia e a recém vertente presidencial da mesma (CASON, POWER, 2009; DANESE, 2009; BURGES, 2010, 2013, 2014; FENWICK, BURGES, POWER, 2017).

Para Danese (2009), essa presença sistemática do presidente trouxe novos desafios, tensões e obstáculos. Para ele, é preciso evitar constrangimentos, no sentido de que o exercício presidencial da diplomacia deveria não apenas estar em sintonia com as diretrizes diplomáticas tradicionais, mas também seu emprego deve ser calibrado e dosado. Já Barnabé (2010) argumenta que:

não houve, em nenhum dos dois governos [FHC e Lula], atritos importantes entre o Ministério e os “Mandatários Diplomatas”. Isso se deve, por um lado, a uma abertura do próprio Itamaraty, que tem acompanhado com sabedoria as transformações mundiais das últimas décadas e, por outro lado, à clareza dos Presidentes no que diz respeito à manutenção da importância da Chancelaria e dos canais próprios do Ministério das Relações Exteriores, ou seja, da Diplomacia Tradicional, no complexo cenário internacional contemporâneo. (BARNABÉ, 2010, p. 44)

Para Cason e Power (2009), a ascensão presidencial na diplomacia pode levar a três efeitos perigosos. O primeiro é de que a política externa passe a ser cada vez mais submetida aos caprichos (the whims) dos presidentes. A segunda implicação é a de que o raciocínio estratégico em política exterior comece a 
buscar apenas resultados salientes e de curto prazo, permitindo, assim, que o líder presidencial faça uma boa propaganda política. Por fim, seria danosa para os interesses nacionais a percepção de que os presidentes passam a ter mais carisma e laços de amizade com alguns líderes em detrimento de outros.

Em sentido semelhante, Burges (2010) argumenta que a diplomacia presidencial pode acabar sendo demasiadamente instável, já que o líder não foi profissionalmente treinado para exercer ritos diplomáticos. Consequentemente, suas palavras podem ser escutadas de forma equivocada e ele também pode acabar interpretando erroneamente determinadas situações que precisam ser levadas com paciência e através de um procedimento diplomático.

Destarte, ao que parece, duas visões prevaleceram nos estudos existentes. A primeira é a que há, via de regra, consonância e convergência entre as pautas enfatizadas por diplomatas profissionais e pela diplomacia presidencial. A segunda é que há dissonância e divergência entre as agendas, já que os objetivos e os interesses entre diplomatas e políticos são diferentes.

Convém mencionar, entretanto, que há pouca literatura teórica e dados empíricos sobre o tema e que, portanto, esse artigo tenta preencher, com um instrumento necessário - mas insuficiente — , uma lacuna que, por si só, é enorme. Ou seja, estudos sobre o conceito de diplomacia presidencial e a natureza de suas interconexões com a vertente tradicional da diplomacia precisam aumentar em número e em qualidade. Para contribuir minimamente com a pluralização desse tema, o restante do artigo trata da metodologia utilizada no emprego dos dados, da apresentação dos resultados obtidos e da discussão acerca do potencial explicativo dos mesmos.

\section{Metodologia}

Os resultados a serem apresentados foram obtidos a partir de técnicas de análise de conteúdo e mineração textual. Elas são ferramentas para a redução ${ }^{6}$ e conversão de dados textuais em categorias quantitativas com o propósito de fazer inferências científicas acerca de atributos latentes nos discursos analisados (WEBER, 1990). Para isso, é necessário seguir um esquema pré-definido de análise para que níveis significativos de validade, de replicabilidade e falseabilidade dos resultados sejam

6 Por serem justamente técnicas de redução de dados, é visível que uma série de informações são perdidas em prol de descobrir determinados padrões de estrutura. Os seus resultados fornecem uma medida aproximada e, portanto, incompleta - da realidade do tecido textual. 
mantidos$^{7}$ (NEUENDORF, 2002). Nesse caso, primeiro, os objetivos da pesquisa foram definidos, depois o corpus foi coletado, os esquemas de codificação escolhidos, em seguida, os textos foram codificados e os resultados obtidos.

Como é de interesse comparar as prioridades do presidente da República com as do seu chanceler em temas ligados às RI durante a posse dos mesmos, o corpus coletado reuniu os discursos de ambos os atores desde o primeiro governo FHC quando se começou a falar em diplomacia presidencial - até a mais recente gestão de Temer. Só não foi possível encontrar o pronunciamento de Celso Amorim no segundo governo Lula, fato que pode subestimar os valores encontrados para tal ator.

Terminada a coleta dos pronunciamentos, iniciou-se a fase da escolha do esquema de codificação que melhor refletisse as necessidades da pesquisa. Para isso, primeiro, era necessário distinguir os temas de política doméstica dos de política externa nos pronunciamentos dos presidentes. A codificação proposta pelo Comparative Agendas Project ${ }^{8}$ foi adotada, por se tratar de um conjunto de códigos que foi aplicado em vários estudos ao redor do mundo e continuou com significativos níveis de validade, o que aumentou a sua confiabilidade (BATISTA, VIEIRA, 2016).

Ela conta com mais de 200 subcategorias predispostas em 21 categorias (BEVAN, 2015). Apenas as categorias foram utilizadas, já que foge ao escopo do artigo realizar uma comparação detalhista do discurso presidencial. A esse respeito, o quadro 1 apresenta esse esquema de codificação, responsável por indicar a tonalidade geral dos pronunciamentos presidenciais e separar temas domésticos de externos.

\section{Quadro 1 - Codificação do Comparative Agendas Project.}

\begin{tabular}{|c|c|c|c|c|}
\hline \multicolumn{5}{|c|}{ Categorias } \\
\hline Macroeconomia & Direitos Civis & Saúde & Agricultura & Trabalho \\
Educação & Meio Ambiente & Energia & Imigração & Transporte \\
Lei e Crime & Questões Sociais & Moradia & Comércio Interno & Defesa \\
Tecnologia & Comércio Exterior & Relações Internacionais & Operações Governamentais & Terras Públicas \\
\hline \multicolumn{2}{|c|}{ Cultura } & Outro \\
\hline
\end{tabular}

Fonte: Elaboração própria com base no Comparative Agendas Project Codebook: BEVAN (2015)

7 O grande desafio da análise de conteúdo é alocar textos em categorias, já que variáveis podem ser enviesadas pelo grau de ambiguidade das frases e por atributos do pesquisador, como processos cognitivos, percepções semânticas, entre outros. Desse modo, nessa pesquisa e em todas as que utilizam tal técnica, é provável a existência de erros. Em função disso, a replicabilidade é tão importante, já que quanto mais repetida uma pesquisa for, mais bem definido será o grau de confiabilidade de seus resultados. Por isso, todos os arquivos de textos, banco de dados e códigos utilizados estarão disponíveis no seguinte repositório: https://dataverse. harvard.edu/dataset.xhtml?persistentId = doi \% 3A10.7910\%2FDVN\%2FMQCASI

8 Para quem deseja obter maiores informações: http://www.comparativeagendas.net/pages/About. 
Originalmente, não existe a categoria “Outro”, mas sua inclusão foi necessária, devido à natureza dos pronunciamentos analisados. Nela, reuniram-se os agradecimentos, as frases cujo conteúdo se referiam à trajetória do emissor e os tópicos sobre a situação contextual da fala. Após ter codificado os discursos presidenciais, os trechos dos pronunciamentos que se ligam às categorias de relações internacionais e de comércio exterior foram separados e novamente categorizados junto aos discursos dos chanceleres, através de outro esquema codificador que se derivou da estrutura presente na página virtual do Itamaraty ${ }^{9}$. O quadro 2 informa tais categorias.

\section{Quadro 2 - Codificação da Página do Itamaraty.}

\begin{tabular}{|c|c|c|c|c|}
\hline \multicolumn{5}{|c|}{ Categorias } \\
\hline $\begin{array}{c}\text { Relações } \\
\text { Bilaterais }\end{array}$ & $\begin{array}{c}\text { Diplomacia econômica, } \\
\text { comercial e financeira }\end{array}$ & $\begin{array}{c}\text { Mecanismos } \\
\text { Inter-regionais }\end{array}$ & $\begin{array}{c}\text { Integração } \\
\text { Regional }\end{array}$ & Cooperação \\
\hline $\begin{array}{c}\text { Direitos humanos } \\
\text { e temas sociais }\end{array}$ & $\begin{array}{c}\text { Desenvolvimento sustentável } \\
\text { e meio ambiente }\end{array}$ & Energia & $\begin{array}{c}\text { Ciência, tecnologia } \\
\text { e inovação }\end{array}$ & $\begin{array}{c}\text { Diplomacia } \\
\text { cultural }\end{array}$ \\
\hline $\begin{array}{c}\text { Paz e segurança } \\
\text { internacionais }\end{array}$ & Brasileiros no exterior & $\begin{array}{c}\text { Atos } \\
\text { internacionais }\end{array}$ & \multicolumn{2}{|c|}{ Outros } \\
\hline
\end{tabular}

Fonte: elaboração própria com base na estrutura da página virtual do Itamaraty (2017)

Inicialmente, a categoria “Outros" foi pensada para reunir conteúdos relacionados a agradecimentos, referências a amigos e familiares e, também, para as frases cuja ambiguidade seria tão significativa a ponto de se tornar impossível alocar uma tonalidade predominante dentre as categorias dessa codificação. Entretanto, como mostrado mais à frente, tal grupo categórico foi um dos mais frequentes entre os pronunciamentos de posse. Por conseguinte, será mais bem examinado em outros gráficos feitos a partir do conteúdo semântico de suas frases.

Cada categoria foi alocada de acordo com a predominância da sua narrativa frasal, sendo, por conseguinte, essa a unidade de análise. Para tanto, optou-se por distinguir o início e o final de uma frase através do ponto final. Isso impõe vantagens e desvantagens.

Dentre os benefícios, destaca-se a utilização de um critério objetivo e automatizado de seleção e de estruturação do corpus. Quanto às desvantagens, as

9 O sistema de codificação apresentado foi baseado na aba "Política Externa” presente na página virtual do Itamaraty, assim como estava disponível no mês de agosto de 2017 (podendo ter havido alguma mudança com o decorrer do tempo). Optou-se por utilizar tal codificação em detrimento de outras, por se tratar de uma divisão endógena e institucionalmente oficial feita pelo próprio Itamaraty para representar os temas de política externa. Para quem deseja obter maiores informações: http://www.itamaraty.gov.br/pt-BR/ 
principais são: a) a possibilidade de que uma só sentença reúna, entre vírgulas, várias categorias; b) a possibilidade de que alguns discursos se tornem mais ou menos extensos apenas por causa de se ter adotado o ponto final como critério de seleção; e, por fim, c) algumas categorias podem ser subestimadas, enquanto outras sobrestimadas, por causa da opção do emissor — ou até mesmo do responsável pela transcrição textual do discurso - em pontuar mais ou menos as falas.

Para saber se as desvantagens da utilização do ponto final foram marginais ou sistemáticas, foram verificadas, cautelosamente, medidas de tendência central e de dispersão. Obtém-se, então, uma noção mais precisa acerca da variação de caracteres com espaço em cada linha de cada pronunciamento ${ }^{10}$. Chegou-se, então, à conclusão de que isso não criou diferenças sistemáticas, com exceção de alguns casos desviantes.

Em termos de formas de visualização, serão apresentados os seguintes tipos de gráficos. Os dois primeiros são gráficos de ponto que mostram o percentual de vezes em que cada ator político analisado citou determinada temática. Em seguida, há uma nuvem de palavras comparando os termos mais frequentes nos discursos de chanceleres e de presidentes. Nela, quanto maior o tamanho das palavras, maior o número de citações. Depois, um dendrograma agrupa os atores políticos de acordo com a distância euclidiana das palavras. Os dois últimos gráficos examinam mais profundamente as subcategorias dentro da categoria "Outros".

Por último, convém deixar claros os seguintes pontos. Primeiro, o potencial de generalização do artigo é baixo. O corpus não é apenas muito pequeno, mas também muito específico. Isso significa que os resultados podem ou não representar a prioridade geral dos atores, o trabalho não entra nesse mérito, já que para isso seria necessário um desenho de pesquisa bem mais robusto e com uma amostra bem maior e aleatória. Entretanto, espera-se com tal artigo que novas reflexões sobre o tema aconteçam e que novas pesquisas se desenhem, vindo a complementar os achados da área. Segundo, convém lembrar que diretriz retórica não necessariamente tem correlação com prática política. O artigo trata de expectativas discursivas, não de realizações materiais. Não obstante, ele pode servir, novamente, como unidade de comparação para pesquisas que desejem cruzar e comparar retórica com realidade. Terceiro, a dominância do método quantitativo impõe uma grande perda de informação sobre o material textual.

10 Um dos comandos de base do R para manipulação de variáveis textuais é o "nchar”. Com ele, foi possível obter a medida do tamanho de elementos contidos em cada frase textual. Vale salientar que esse comando contabilizou também espaços em branco. 
Portanto, sugere-se a ampliação de estudos que usem métodos diversos (qualitativos e quantitativos) para, assim, avançar ainda mais no tema.

\section{Resultados}

O gráfico 1 apresenta as ênfases temáticas nas posses presidenciais. A partir dele, é possível visualizar, através de um indicador quantitativo, o peso dado às RI durante esse rito protocolar dos atores políticos.

\section{Gráfico 1 - Percentuais das Ênfases Temáticas nas Posses dos Presidentes}

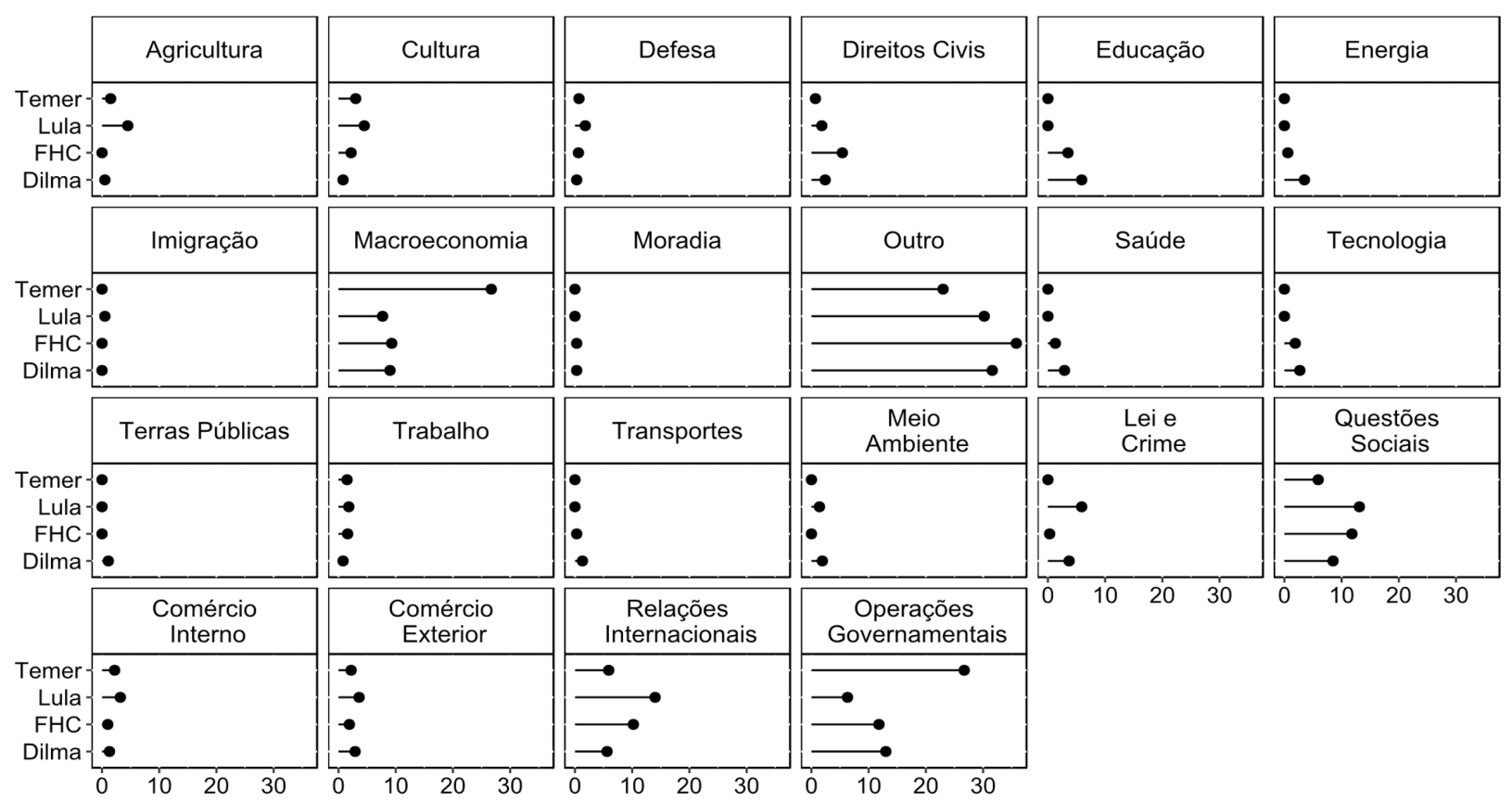

Fonte: Elaboração própria.

A categoria mais mencionada foi “Outro" (média de 30,1\%). Isso indica que, em média, a codificação empregada foi capaz de alocar e classificar o conteúdo de $70 \%$ dos pronunciamentos presidenciais. A considerar os propósitos do artigo, esse é um bom nível de proporção. Agregados, os temas voltados às RI e comércio exterior ocuparam, em média, 5,7\% dos discursos de posse. Os presidentes que menos e mais mencionaram tais tópicos foram Michel Temer (4\%) e Lula (8,8\%), respectivamente.

Nota-se que, em suas duas posses, FHC priorizou as categorias referentes às questões sociais $(11,8 \%)$, operações governamentais $(11,8 \%)$, RI $(10,2 \%)$ e macroeconomia (9,3\%). Em Lula, foram mais mencionadas: RI (14\%), questões sociais $(13,1 \%)$, macroeconomia $(7,7 \%)$ e operações governamentais $(6,3 \%)$. 
Dilma falou mais em termos de operações governamentais (13\%), macroeconomia (9\%), questões sociais e Temer pronunciou mais as categorias de macroeconomia $(26,7 \%)$ e operações governamentais $(26,7 \%)$. Com efeito, ele dedicou mais da metade de sua fala de posse a tais tópicos.

É perceptível a repetição das categorias cuja frequência nunca diminui drasticamente, como macroeconomia, operações governamentais e questões sociais, enquanto há outras cuja ênfase, dificilmente, foi ampliada de forma significativa, tais quais imigração, terras públicas, moradia e trabalho. Uma exceção é agricultura, cujos valores, via de regra, variaram entre 0 e 1,5\% no espaço de posse dos pronunciamentos, salvo em Lula, que dedicou 4,5\% para tal questão.

Tendo distinguido temas domésticos de externos, é possível verificar a frequência de citações às questões internacionais na posse dos presidentes e dos chanceleres, conforme mostrado no gráfico 2 .

\section{Gráfico 2 - Percentuais das Ênfases Temáticas dos Presidentes e dos Chanceleres}

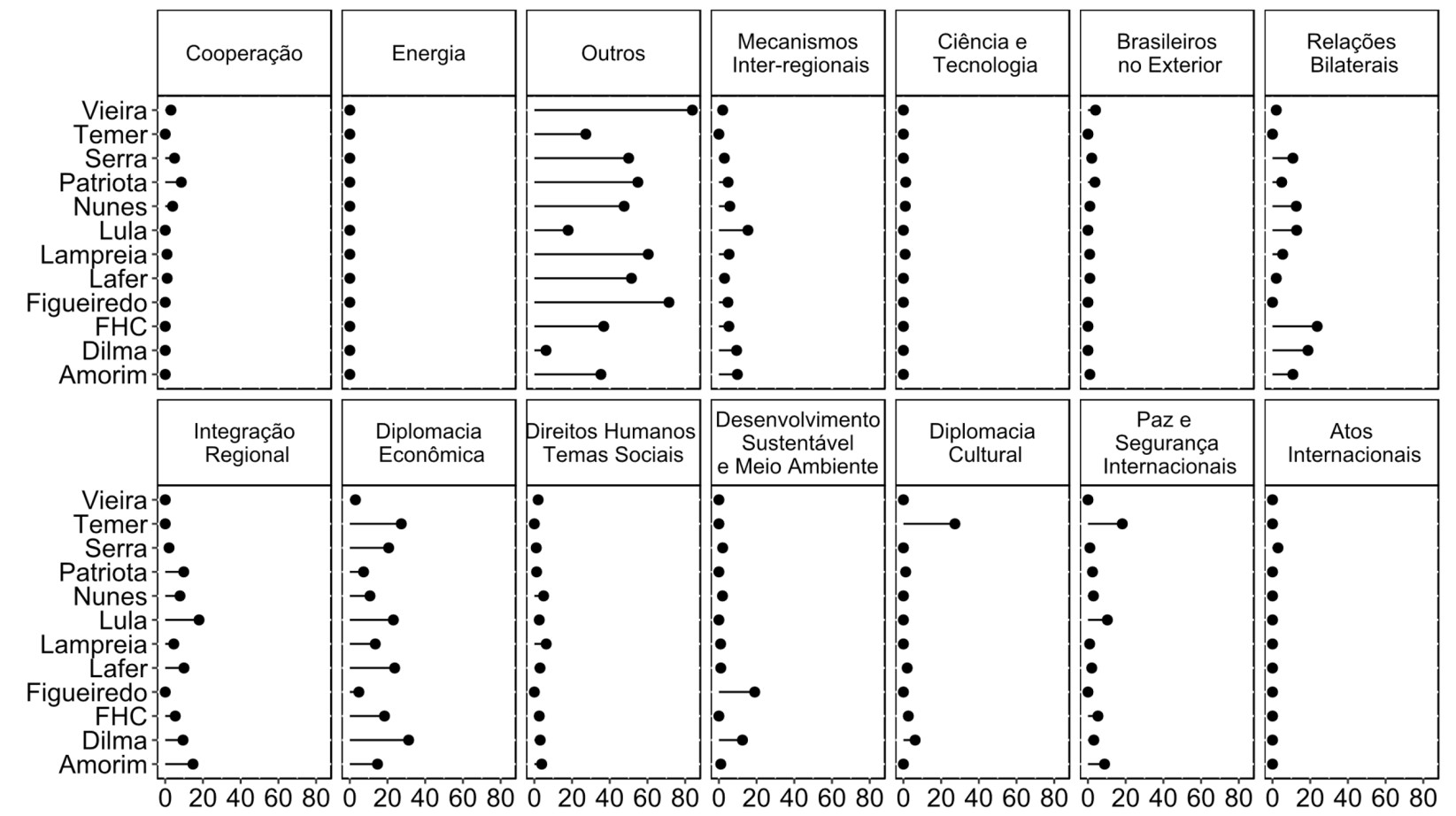

Fonte: Elaboração própria.

Energia, atos internacionais, brasileiros no exterior, ciência, tecnologia e cooperação possuíram um nível de citações constantemente baixo nas posses dos presidentes e dos chanceleres. Em razão disso, não há muito detalhe a sublinhar sobre os mesmos, já que eles estão mais próximos de constantes do que de variáveis, ao menos, no rito de posse. 
Quanto à categoria “Outros”, surpreendentemente, ela foi muito significativa. Em média, explica 45,2\% do conteúdo dos pronunciamentos. Esse número é maior para os chanceleres (média de $56,8 \%$ ) do que para os presidentes (média de $22 \%$ ), fato que indica que os primeiros tendem a ser mais gerais e menos adjacentes aos tópicos definidos na página virtual do Itamaraty do que os últimos. Ainda assim, isso indica a baixa qualidade da codificação construída e mostrada no gráfico 2 . Portanto, na última parte dessa seção, tal categoria será mais aprofundada.

Em suas cerimônias de posse, três categorias dominaram 47,4\% do discurso de FHC ao se referir a temas de RI e comércio exterior, sendo elas: relações bilaterais do país $(23,7 \%)$, diplomacia econômica $(18,4 \%)$ e paz e segurança internacionais (5,3\%). Luiz Felipe Lampreia, chanceler de 1995 a 2001, enfatizou temas ligados à diplomacia econômica, comercial e financeira $(13,5 \%)$, direitos humanos e temas sociais $(6,3 \%)$, relações bilaterais e mecanismos inter-regionais, ambos com $5,4 \%$. Ao que parece, não houve grandes assimetrias na priorização dada a esses tópicos entre ambos os atores. Com a aposentadoria de Lampreia, FHC escolheu Celso Lafer para ser seu chanceler entre 2001 e 2003. Por sua vez, Lafer enfatizou os temas de diplomacia econômica $(23,8 \%)$ e de integração regional $(9,9 \%)$.

Durante as posses de Lula, diplomacia econômica $(23,8 \%)$, integração regional $(17,9 \%)$, mecanismos inter-regionais $(15,4 \%)$ e relações bilaterais $(12,8 \%)$ receberam as maiores citações. De forma convergente, Celso Amorim - chanceler de 2003 a 2010 — priorizou temas referentes à integração regional, diplomacia econômica (ambos com 14,7\%) e relações bilaterais (10,8\%).

Em Dilma, as maiores menções se referem à diplomacia econômica $(31,2 \%)$, relações bilaterais $(18,8 \%)$ e desenvolvimento sustentável e meio ambiente $(12,5 \%)$. Antonio Patriota, chanceler da presidente de 2011 a 2013, não priorizou o espaço dos temas de desenvolvimento sustentável e meio ambiente ( 0 \%), mas mencionou tópicos de integração regional (9,8\%) e de diplomacia econômica (7,3\%). Já Luiz Alberto Figueiredo, chanceler de 2013 a 2015, optou por voltar a aumentar a visibilidade dos temas de desenvolvimento sustentável e meio ambiente (19\%) e enfatizar a diplomacia econômica e mecanismos inter-regionais, ambos ocupando 4,8\% de seu discurso. Por fim, Mauro Vieira, chanceler de 2015 a 2016, priorizou temas sobre brasileiros no exterior $(4 \%)$, cooperação e diplomacia econômica (ambos com 3\%).

Por último, Temer deu maior prioridade para tópicos de diplomacia econômica, diplomacia cultural (ambos com 27,3\%) e paz e segurança internacionais (18,2\%). O primeiro chanceler dele foi José Serra, entre 2016 e 2017, que enfatizou 
diplomacia econômica $(20,6 \%)$ e relações bilaterais (10,8\%). Já Aloysio Nunes, chanceler a partir de março de 2017, priorizou tópicos de relações bilaterais $(12,6 \%)$ e diplomacia econômica, comercial e financeira $(10,7 \%)$.

Com tais evidências, pode-se concluir que, ao menos em discursos de posse, tanto os presidentes quanto os seus chanceleres tenderam a manter um padrão de ênfase temática constante, sendo que mudanças ocorreram pontual e marginalmente. Tópicos relacionados à diplomacia econômica, relações bilaterais e integração regional, por exemplo, permaneceram priorizados ao longo do tempo. Por outro lado, energia, atos internacionais, brasileiros no exterior e ciência e tecnologia tenderam a um grau de saliência constante e insignificativo, quando não nulo.

Para construir uma noção mais precisa acerca de qual foi o nível de associação entre os presidentes e os chanceleres, é importante verificar os valores de correlação entre eles. Para tanto, utilizou-se os textos dos discursos voltados para RI e técnicas de mineração textual foram executadas nos mesmos. Ou seja, a partir de agora, ignora-se as categorias e considera-se, novamente, o conteúdo. A primeira forma de verificar semelhanças e diferenças é verificando os termos mais utilizados por presidentes e por chanceleres, isso pode ser visto a partir da figura 1 .

Figura 1 - Nuvens de Palavras Comparando Presidentes e Chanceleres

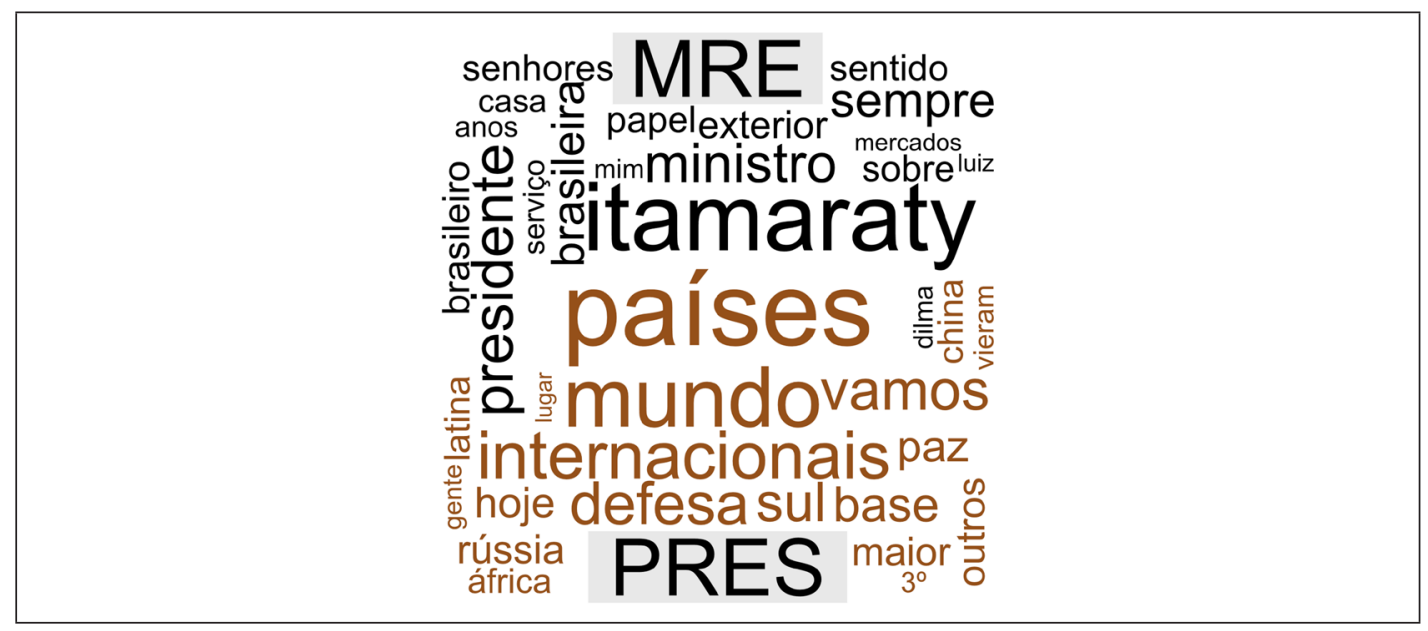

Fonte: Elaboração própria.

Chanceleres tendem a mencionar termos como Itamaraty, ministro, presidente, serviço, brasileiros. Presidentes, por sua vez, tendem a falar em "países", "mundo", “defesa”, "sul” etc. A partir dessa abordagem, é possível ir ainda além e calcular medidas de distância e de similaridade. A figura 2 traz um dendrograma que mostra como a distância euclidiana normalizada das palavras permite agrupar os atores aqui analisados em clusters. 


\section{Figura 2 - Dendrograma Agrupando Presidentes e Chanceleres}

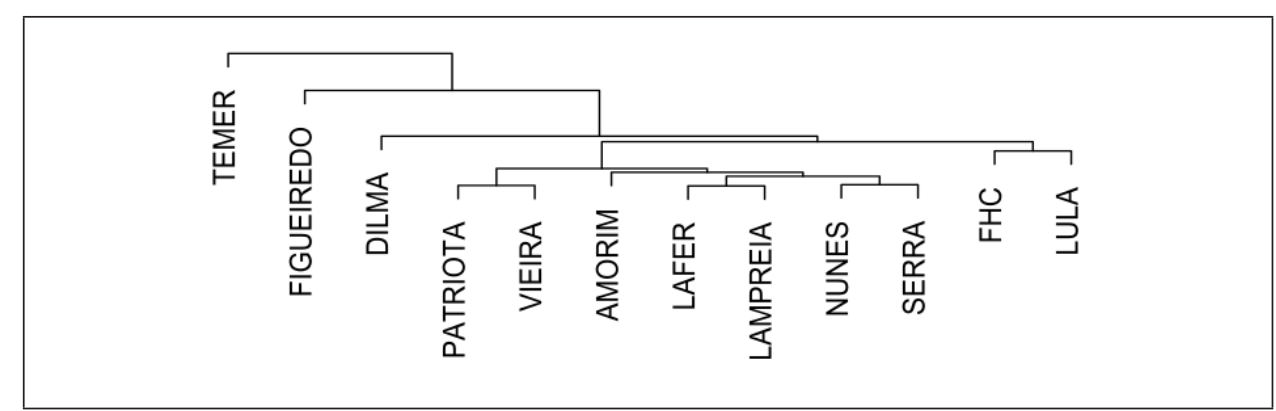

Fonte: Elaboração própria.

Os resultados são interessantes. Como se nota, o presidente Temer é o que mais se distância de todos os outros. Isso significa que o grau de associação de seu pronunciamento de posse é mais baixo em relação ao padrão dos outros. Em seguida, tem-se Figueiredo e depois Dilma. Ambos também possuem um nível considerável de distanciamento. A ligação entre FHC, Lula e os demais chanceleres já é maior. No caso de FHC e Lula, há um agrupamento entre ambos, o que, ao mesmo tempo, os torna mais distantes de Dilma. Curioso mesmo são os ramos do cluster que existe entre os chanceleres; todos - com exceção de Figueiredo - partilham proximidades. Alguns mais que outros. Por exemplo, Nunes e Serra estão muito mais próximos entre si; bem como Lampreia e Lafer e Vieira e Patriota.

Para finalizar, é necessário descrever detalhadamente a categoria “Outros”, pois ela ocupou, em média, 45,2\% de todos os pronunciamentos analisados. A fim de entender melhor o conteúdo latente de tal categoria, foi realizada uma análise qualitativa temática que buscou alocar todas as sentenças de acordo com a natureza de seu argumento retórico. O gráfico 3 apresenta alguns resultados.

\section{Gráfico 3 - Frequência e Conteúdo das Sentenças da CategorizOutros”}

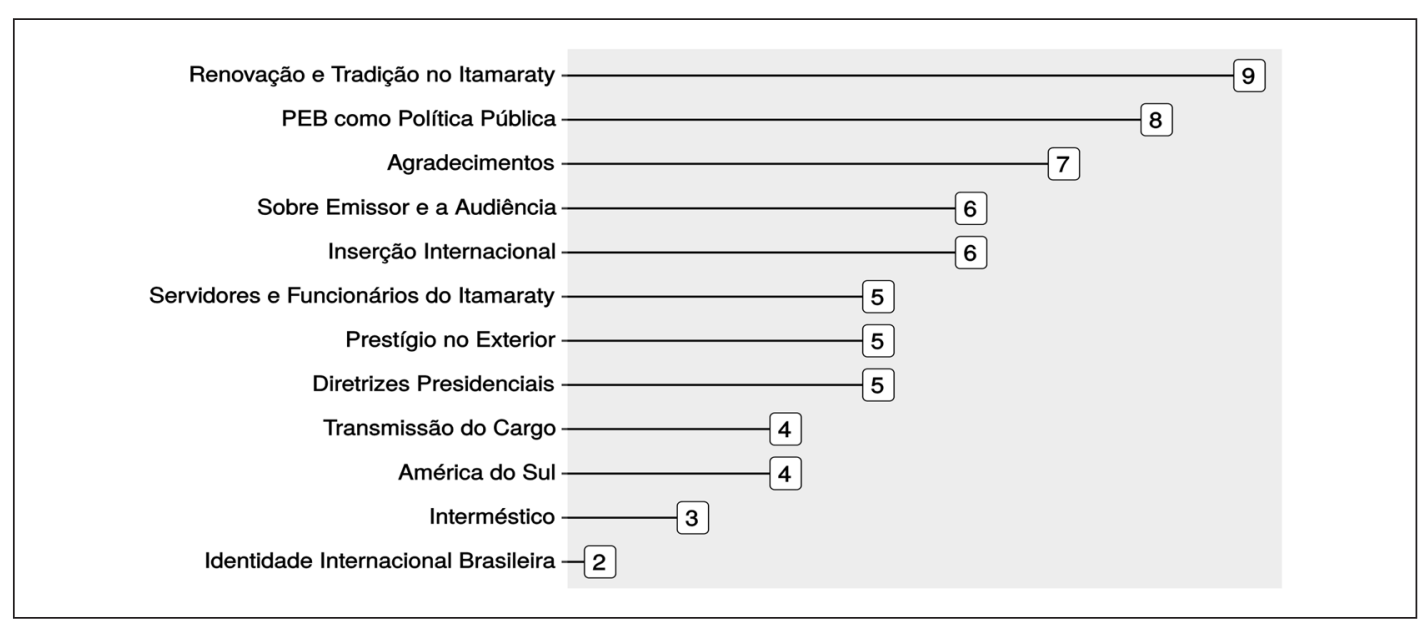

Fonte: Elaboração própria. 
O gráfico 3 mostra a contabilização do conteúdo e da frequência de cada sentença da categoria "Outros", o que permite saber quais delas foram predominantes nas falas de posse. Por exemplo, dos 14 discursos, 9 citaram sentenças relacionadas à necessidade de manutenção da tradição e da renovação no Itamaraty. Embora isso pareça contraditório, cabe lembrar que um dos grandes lemas de tal instituição é o de que a sua melhor tradição é saber se renovar (FARIA, LOPES e CASARÕES, 2013). Em seguida, o conteúdo mais citado dentre as sentenças alocadas na categoria "Outros" foi o que fez referência à PEB como sendo uma política pública, aparecendo em 8 dos 4 pronunciamentos.

A expectativa era que frases relacionadas a agradecimentos e ao contexto do emissor e da audiência fossem as mais frequentes. O que se percebe é que tais frases ficaram em terceira e quarta prioridades, já que, de um total de 14 discursos de posse, as mesmas foram citadas em apenas 7 e 6 pronunciamentos, respectivamente. Um ponto curioso é que, embora conteúdos que tentem equivaler a PEB à política pública estejam entre os mais citados, menções referentes ao nível "interméstico"11 estão entre as menos recorrentes, aparecendo em apenas 3 dos 14 pronunciamentos. Embora informativo, um dos limites do gráfico 4 é que ele não mostra quem falou mais ou menos o quê. Para descobrir isso, seguem os valores percentuais no gráfico 4 .

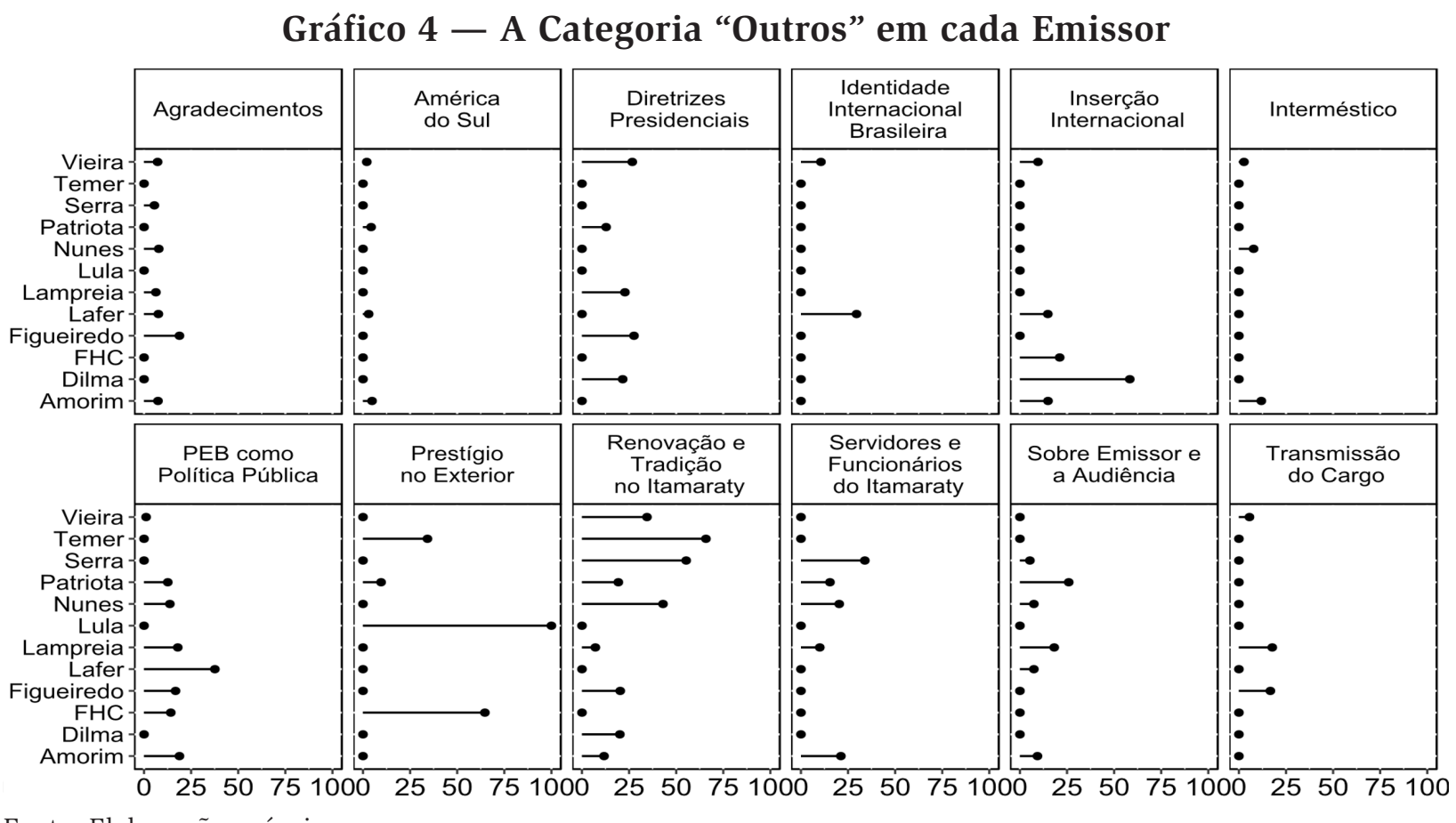

Fonte: Elaboração própria.

11 Segundo Figueira (2011), o neologismo ‘interméstico’ representa a junção das palavras internacional e doméstico e diz respeito à diluição desses dois níveis no cenário contemporâneo. Ou seja, a divisão entre assuntos internos, como sendo aqueles que surgem da fronteira nacional para "dentro", e assuntos externos, como estando da fronteira nacional para "fora”, perde em muito seu alcance explicativo. 
O gráfico 4 mostra que o discurso de identidade internacional do Brasil foi dominante nas posses de Vieira e Lafer. Esse último também foi quem mais falou na PEB em termos de política pública. Lula, por excelência, é que mais citou a questão do prestígio brasileiro no exterior, seguido por FHC. Dilma foi quem mais mencionou questões referentes à inserção internacional do Brasil e Temer foi quem mais citou o tema da renovação e tradição no Itamaraty.

Para finalizar a apresentação dos resultados, convém lembrar que os mesmos são de natureza mais indicativa e sugestiva do que conclusiva. Eles servem como um indicador necessário - mas insuficiente - de quais categorias foram mais ou menos mencionadas pelos presidentes e pelos chanceleres ao pronunciarem suas palavras durante o rito da posse. Ao se verificar o padrão encontrado, percebe-se a existência de uma continuidade, tanto na significância quanto na insignificância de certos temas.

\section{Conclusões}

Neste artigo, explorou-se a questão da necessidade de olhar a política externa como sendo política pública e, a partir disso, propor desenhos investigativos que verifiquem a plausibilidade de certos pressupostos existentes na literatura sobre a PEB. Aqui, a possibilidade problematizada foi a de haver uma agenda específica do presidente da República e do seu chanceler, na medida em que eles enfatizariam temas diferentes nos seus discursos de posse.

Inicialmente, discutiu-se a questão das rupturas e continuidades no padrão decisório da PEB. Nesse aspecto, foi mencionado o conceito de equilíbrio pontuado como sendo uma possibilidade analítica que harmoniza o melhor de ambas as tradições, a que vê a política externa como sendo política de Estado e a que a vê como sendo política pública governamental. O equilíbrio pontuado afirma que a continuidade é a tendência e as rupturas são desvios importantes que podem criar novas continuidades. A partir disso, monitorar como os atores políticos minimizam e maximizam a priorização de determinadas questões é essencial. Isso pode ser feito na dimensão política prática ou nas pautas retóricas das agendas.

Nesse artigo, o objetivo principal foi fixar-se nessa segunda dimensão e verificar a agenda de diretrizes dos presidentes e chanceleres brasileiros em um momento bastante específico, o de posse dos mesmos. Para tanto, foram empregadas técnicas de análise de conteúdo e de mineração textual. Através das mesmas, foi possível verificar que, independente do mandato presidencial, questões como imigração, 
terras públicas, moradia e trabalho são quantitativa e constantemente insignificante, ao passo que as categorias de macroeconomia, operações governamentais e questões sociais são mantidas com alta visibilidade repetitiva.

O mesmo padrão se repete quando se considera apenas a parcela dos discursos dos presidentes e os pronunciamentos dos chanceleres sobre temas de RI. Atos internacionais, ciência e tecnologia, cooperação, brasileiros no exterior e direitos humanos e temas sociais são invisíveis no momento de posse. Percebe-se, também, que os chanceleres - com exceção de Figueiredo - tendem a estar agrupados de um modo muito coeso, segundo indicam valores de distância textual (cosine similarity). Por fim, parte importante dos pronunciamentos fala em outras categorias, dentre as quais a questão da renovação e tradição no Itamaraty, a PEB como sendo política pública, inserção internacional e prestígio no exterior.

Algumas ressalvas aos limites dos achados aqui expostos devem ser refeitas. Primeiramente, é válido lembrar que os resultados só dizem respeito ao padrão retórico encontrado nos pronunciamentos de posse dos chanceleres e dos presidentes. Naturalmente, esse tipo de dado é necessário, mas insuficiente. Necessário, pois tais discursos podem ser pensados como sendo uma unidade primeira das principais diretrizes estabelecidas pelos atores. Ademais, eles servem como um ponto interessante de comparação, porque permitem o contraste das proposições iniciais com a ação e o discurso ao longo da gestão. Por outro lado, esse tipo de dado é por si só insuficiente, já que ele é demasiadamente limitado. Portanto, não é representativo da dimensão discursiva dos emissores como um todo.

Cabe também enfatizar a necessidade de trabalhos que busquem replicar a codificação utilizada aqui. Em análise de conteúdo, o padrão de ouro se alcança através da realização de testes que busquem reproduzir novamente os passos seguidos nos desenhos de pesquisas e, assim, realçar pontos convergentes e divergentes, erros e acertos. Apenas desse modo se faz possível ter uma certificação adequada acerca de sua confiabilidade. Por esse motivo, todos os materiais estão disponibilizados em repositório virtual, anteriormente indicado.

\section{Referências}

BARNABÉ, Israel Roberto. O Itamaraty e a Diplomacia Presidencial nos Governos FHC e Lula. Revista de Estudos Internacionais (REI), v. 1, n. 2, 2010, p. 29-45. Disponível em: http://www.revistadeestudosinternacionais.com/uepb/index.php/rei/article/ view/22/pdf. Acesso em: 31, ago. 2017. 
BATISTA, David do Nascimento. Habitus diplomático: um estudo do Itamaraty em tempos de regime militar (1964-1985). 2010. 218 f. Tese (Doutorado) - Curso de Sociologia, Programa de Pós-Graduação em Sociologia, Universidade Federal de Pernambuco, Recife, 2010. Disponível em: http://www.repositorio.ufpe.br/handle/123456789/9199. Acesso em: 30, ago. 2017.

BATISTA, Mariana; VIEIRA, Bhreno. Mensurando Saliência: Uma Medida com Base em Ênfases na Agenda Legislativa do Brasil (1995-2014). In: 10 Encontro da Associação Brasileira de Ciência Política, 2016, Belo Horizonte. Anais Eletrônicos. Disponível em: https://cienciapolitica.org.br/system/files/documentos/eventos/2017/04/ mensurando-saliencia-medida-com-base-enfases-agenda.pdf. Acesso em:31, ago. 2017.

BAUMGARTNER, Frank R et al. Lobbying and Policy Change: Who Wins, Who Loses and Why. Chicago: The University Of Chicago Press, 2009.

BERSCH, Katherine; PRAÇA, Sérgio; TAYLOR, Matthew M. State Capacity, Bureaucratic Politicization, and Corruption in the Brazilian State. Governance, v. 30, n. 1, 2017 , p. 105-124. Disponível em: 10.1111/gove.12196. Acesso em: 30, ago. 2017.

BEVAN, Shaun. General Comparative Agendas Project Coding Guidelines. Comparative Agendas Project, 2015. Disponível em: http://sbevan.com/cap-master-codebook. html. Acesso em: 31 Ago. 2017.

BRASIL. Constituição Federal: Promulgada em 5 de Outubro de 1988. Porto Alegre: Verbo Jurídico, 2003.

BURGES, Sean W; BASTOS, Fabrício H. Chagas. The Importance of Presidential Leadership for Brazilian Foreign Policy. Policy Studies, v. 38, n. 3, 2017, p. 277-290. Disponível em: https://doi.org/10.1080/01442872.2017.1290228. Acesso em: 30, ago. 2017

BURGES, Sean W. Desafio para o Itamaraty. Política Externa, v. 22, n. 4, 2014, p. 1-11. Disponível em: http://politicaexterna.com.br/2395/desafio-para-o-itamaraty/. Acesso em: 30, ago. 2017.

BURGES, Sean W. Seria o Itamaraty um Problema para a Política Externa Brasileira?. Política Externa, v. 21, n. 3, 2013, p. 133-148. Disponível em: http://politicaexterna. com.br/190/133-seria-itamaraty-problema-politica-externa-brasileira/. Acesso em: 31, ago. 2017.

BURGES, Sean W. The Possibilities and Perils of Presidential Diplomacy: Lessons from the Lula years in Brazil. In: ROLLAND, Dennis; LESSA, Antonio Carlos. Relations Internationales du Brésil: Les Chemins de la Puissance. Paris: L'Harmattan, 2010. Cap. 1, p. $1-11$.

CASON, Jeffrey W; POWER, Timothy J. Presidentialization, Pluralization, and the Rollback of Itamaraty: Explaining Change in Brazilian Foreign Policy Making in the Cardoso-Lula era. International Political Science Review, v. 30, n. 2, 2009, p. 117-140. Disponível em: https://www.jstor.org/stable/25652895. Acesso em: 31, ago. 2017. 
CHEIBUB, Zairo B. A Carreira Diplomática no Brasil: O Processo de Burocratização no Itamarati. Revista de Administração Pública, v. 23, n. 2, 1989, p. 97-128. Disponível em: http://bibliotecadigital.fgv.br/ojs/index.php/rap/article/view/9157/8261. Acesso em: 31, ago. 2017.

DANESE, Sérgio. A Escola da Liderança: Ensaios sobre a Política Externa e a Inserção Internacional do Brasil. Rio de Janeiro: Editora Record, 2009.

DINIZ, Simone; RIBEIRO, Cláudio Oliveira. The role of the Brazilian congress in Foreign Policy. Brazilian Political Science Review, v. 2, n. 2, 2008, p. 10-38. Disponível em: http://www.bpsr.org.br/index.php/bpsr/article/view/32. Acesso em: 30, ago. 2017.

DINIZ FILHO, Paulo Ricardo. Insulamento ou Isolamento? A articulação do Ministério das Relações Exteriores no âmbito do Governo Federal (2000-2011). Conjuntura Austral, v. 4, n. 15, 2013, p. 70-85. Disponível em: http://seer.ufrgs.br/index.php/ ConjunturaAustral/article/view/26870. Acesso em: 31, ago. 2017.

DYE, Thomas R. Mapeamento dos Modelos de Análise de Políticas Públicas. In: HEIDEMANN, F. G; SALM, J. F. Políticas Públicas e Desenvolvimento: Bases Epistemológicas e Modelos de Análise. Brasília: UnB, 2010. Cap. 3, pp. 98-129.

FARIA, Carlos Aurélio Pimenta de. O Itamaraty e a Política Externa Brasileira: Do Insulamento à Busca de Coordenação dos Atores Governamentais e de Cooperação com os Agentes. Revista Brasileira de Política Internacional, v. 34, n. 1, 2012, p. 311-355. DOI: http://dx.doi.org/10.1590/S0102-85292012000100009. Acesso em: 30, ago. 2017. FARIA, Carlos Aurélio Pimenta de; LOPES, Dawisson Belém; CASARÕES, Guilherme.. Itamaraty on the Move: Institutional and Political Change in Brazilian Foreign Service under Lula da Silva’s Presidency (2003-2010). Bulletin of Latin American Research, v. 32, n. 4, 2013, p. 468-482. DOI: 10.1111/blar.12067. Acesso em: 31, ago. 2017.

FARIAS, Rogério de Souza; RAMANZINI JÚNIOR, Haroldo. Revisando a Horizontalização: O Desafio da Análise da Política Externa Brasileira. Revista Brasileira de Política Internacional, v. 58, n. 2, 2015, p. 5-22. Disponível em: http://dx.doi.org/10.1590/00347329201500201. Acesso em: 30, ago. 2017.

FENWICK, Tracy B; BURGES, Sean W; POWER, Timothy J. Five Faces of Presidential Governance: Insights from Policy-Making in Democratic Brazil. Policy Studies, v. 38, n. 3, 2017, p. 205-215. Disponível em: https://doi.org/10.1080/01442872.2017.129 0232. Acesso em: 31, ago. 2017.

FIGUEIRA, Ariane Roder. Introdução à Análise de Política Externa. São Paulo: Saraiva, 2011. FIGUEIRA, Ariane Roder. Um Debate acerca do Padrão Decisório em Política Externa no Brasil. Carta Internacional, v. 5, n. 1, 2010, p. 38-52. Disponível em: https://www. cartainternacional.abri.org.br/Carta/article/view/528. Acesso em: 31, ago. 2017.

FIGUEIRA, Ariane Roder. Processo Decisório em Política Externa no Brasil. 2009. 255 f. Tese (Doutorado) - Curso de Ciência Política, Departamento de Ciência Política, Universidade de São Paulo, São Paulo, 2009. 
HOUGHTON, David. 2007. 'Reinvigorating the Study of Foreign Policy Decision Making: Toward a Constructivist Approach'. Foreign Policy Analysis, v. 3, n., 2007, p. 24-45. Disponível em: 10.1111/j.1743-8594.2007.00040.x. Acesso em: 31, ago. 2017.

LOPES, Dawisson Belém. A Política Externa Brasileira e a "Circunstância Democrática”: Do Silêncio Respeitoso à Politização Ruidosa. Revista Brasileira de Política Internacional, v. 54, n. 1, 2011, p. 67-86. Disponível em: http://dx.doi.org/10.1590/S003473292011000100005. Acesso em: 30, ago. 2017.

LOPES, Dawisson Belém; FARIA, Carlos Aurélio Pimenta de. Eleições Presidenciais e Política Externa Brasileira. Estudos Internacionais, v. 2, n. 2, 2014, p. 139-148. Disponível em: http://periodicos.pucminas.br/index.php/estudosinternacionais/ article/view/9751. Acesso em: 31, ago. 2017.

MILANI, Carlos; PINHEIRO, Leticia. Política Externa Brasileira: Os Desafios de sua Caracterização como Política Pública. Contexto Internacional, v. 35, n. 1, 2013, p. 11-41. Disponível em: http://dx.doi.org/10.1590/S0102-85292013000100001. Acesso em: 30, ago. 2017.

MIYAMOTO, Shiguenoli. As Grandes Linhas da Política Externa Brasileira. Brasília, DF: CEPAL Escritório no Brasil/IPEA, 2011.

MOURA, Cristina Patriota de. O Inglês, o Parentesco e o Elitismo na Casa de Rio Branco. Cena Internacional, $v$. 8, n. 1, 2006, p. 20-34. Disponível em: http://132.248.9.34/ hevila/CENAInternacional/2006/vol8/no1/2.pdf. Acesso em: 31, ago. 2017.

NETO, Octavio A. De Dutra a Lula: A Condução e os Determinantes da Política Externa Brasileira. Rio de Janeiro: Campus Elsevier, 2011.

NEUENDORF, Kimberley A. The Content Analysis Guidebook. London: SAGE, 2002.

ONUKI, Janina; OLIVEIRA, Amâncio Jorge de. Eleições, Política Externa e Integração Regional. Revista de Sociologia e Política, v. 27, n., 2006, p. 145-155. Disponível em: http://www.scielo.br/pdf/rsocp/n27/10.pdf. Acesso em: 31, ago. 2017.

PRETO, Alessandra Falcão. O Conceito de Diplomacia Presidencial: O Papel da Presidência da República na Formulação de Política Externa. 2006. 101 f. Dissertação (Mestrado) - Curso de Ciência Política, Departamento de Ciência Política, Universidade de São Paulo, São Paulo, 2006.

PUTNAM, Robert D. Diplomacy and Domestic Politics: The Logic of Two-level Games. International Organization, v. 42, n. 3, 1988, p. 427-460. Disponível em: http:// www.jstor.org/stable/2706785. Acesso em: 31, ago. 2017.

SATO, Eiiti. A Diplomacia Presidencial Brasileira e as Trasformações em Curso nas Relações Internacionais. In: PEIXOTO, João Paulo M. Presidencialismo no Brasil: História, Organização e Funcionamento. Brasília: Senado Federal, Coordenação de Edições Técnicas, 2015, Cap. 7, p. 255-293. 
SOUZA, Celina. Políticas Públicas: Uma Revisão da Literatura. Political Science, v. 8, n. 16, 2006, p. 20-45. Disponível em: http://dx.doi.org/10.1590/S1517-45222006000200003. Acesso em: 31, ago. 2017.

TRUE, James L; JONES, Bryan D; BAUMGARTNER, Frank R. Punctuated-equilibrium theory: Explaining Stability and Change in Public Policymaking. In: SABATIER, Paul. Theories of the Policy Process. Boulder, CO: Westview Press, 2006. Cap. 3, p. 59-105. WALT, Stephen M. Alliance Formation and the Balance of World Power. International Security, v. 9, n. 4, 1985, p. 3-43. Disponível em: http://www.jstor.org/stable/2538540. Acesso em: 31, ago. 2017.

WEBER, Robert P. Basic Content Analysis. London: Sage University Press, 1990. 


\title{
O diálogo entre saúde e política externa brasileira nos governos de Fernando Henrique Cardoso (1995-2002) e Luiz Inácio Lula da Silva (2003-2010)
}

\author{
The dialogue between health and the \\ brazilian foreign policy in the governments \\ of Fernando Henrique Cardoso (1995-2002) \\ and Luiz Inácio Lula da Silva (2003-2010)
}

DOI: $10.21530 /$ ci.v12n3.2017.630

Tayná Marques Torres Barboza ${ }^{1}$

Leticia Pinheiro ${ }^{2}$

Fernando Pires-Alves ${ }^{3}$

\section{Resumo}

O presente artigo busca verificar a instrumentalidade do tema da saúde para a participação ativa e propositiva do Brasil na política internacional entre 1995 e 2010. O tema provocava discussões complexas, constantes e marcantes em diversos fóruns globais nesse período, quando os governos de Fernando Henrique Cardoso e Luiz Inácio Lula da Silva buscavam uma atuação internacional relevante e influente. Seus governos divergiam sobre as responsabilidades e oportunidades do Brasil no sistema internacional, mas compartilhavam o objetivo de assumir posição de influência na política internacional. Na busca estratégica por credibilidade, no período FHC, e por autonomia, no período Lula da Silva, o país assumia uma espécie de dever global, que seria realizado por meio de diversas parcerias internacionais e pela participação em instituições globais de relevo. Nesse esforço, parecia necessário formalizar o tratamento do tema da saúde na agenda da política externa brasileira, o que ocorreria em um processo de institucionalização que implicou, entre 1995 e 2010, a adoção

1 Escola Nacional de Saúde Pública Sergio Arouca (ENSP) da Fundação Oswaldo Cruz (FIOCRUZ), Rio de Janeiro/RJ, Brasil. E-mail: taynamtb@gmail.com

2 Instituto de Estudos Sociais e Políticos (IESP) da Universidade do Estado do Rio de Janeiro (UERJ), Rio de Janeiro/RJ, Brasil. E-mail: pinheiro.leticia14@gmail.com

3 Casa de Oswaldo Cruz (COC) da Fundação Oswaldo Cruz (FIOCRUZ), Rio de Janeiro/RJ, Brasil. E-mail: fpiresalves@gmail.com

Artigo submetido em 12/02/2017 e aprovado em 02/06/2017. 
de mudanças no nível político-administrativo dos ministérios das Relações Exteriores e da Saúde e em menções crescentes ao tema da saúde nos discursos das autoridades brasileiras nos fóruns internacionais.

Palavras-chave: Política Externa Brasileira; Saúde Global; Diplomacia da Saúde.

\begin{abstract}
This article seeks to verify the instrumentality of Health for the active and purposeful participation of Brazil in international politics between 1995 and 2010. The theme provoked complex, constant and striking discussions in several global forums during this period, when the governments of Fernando Henrique Cardoso and Luiz Inácio Lula da Silva sought a relevant and influential international performance. Their governments differed on Brazil's responsibilities and opportunities in the international system, but they shared the goal of assuming a position of influence in international politics. In the strategic search for credibility during FHC mandates and for autonomy in Lula da Silva's period, the country assumed a kind of global duty, which would be carried out through various international partnerships and the participation in relevant global institutions. In this effort, it seemed important to formalize the treatment of Health on the agenda of Brazilian foreign policy. This would provoke a process of institutionalization that resulted in the adoption of changes in the political-administrative levels of the Ministry of Foreign Affairs and the Ministry of Health and in the increasing mention of Health in Brazilian authorities' speeches in international forums between 1995 and 2010.
\end{abstract}

Keywords: Brazilian Foreign Policy; Global Health; Health Diplomacy.

\title{
Introdução
}

O presente artigo objetiva sistematizar o diálogo ocorrido entre as áreas de política externa brasileira e saúde nos governos Fernando Henrique Cardoso (1995-2002) e Luiz Inácio Lula da Silva (2003-2010). Sua ênfase recai sobre a relação entre atuação internacional em saúde e a influência dessa na política internacional, bem como sobre a identificação das formas pelas quais teria ocorrido o processo de institucionalização ${ }^{4}$ do tema da saúde na agenda da política externa brasileira.

4 O termo "institucionalização" é, neste trabalho, entendido como o processo que torna formal a presença da saúde na agenda externa do Brasil. Ou seja, institucionalizar o tema da saúde significa torná-lo tema oficial dessa agenda política, e não um item temporário, informal, de baixa relevância política ou incapaz de mobilizar significativos esforços de implementação. Por meio da institucionalização, a saúde ultrapassa os limites dos "bastidores" da formulação da política externa e passa a ser um tema de caráter sólido, não necessariamente prioritário, mas dotado de atores políticos, mecanismos e espaços político-administrativos próprios. 
Neste trabalho, procuramos identificar o porquê desses governos considerarem importante formalizar o tratamento do tema da saúde na agenda da política externa brasileira. Nossa hipótese é que, em vista de um relativo consenso no plano internacional que ressaltava a importância do tema da saúde na condução das relações internacionais, formou-se a posição de que atuar nessa área ajudaria o Brasil a viabilizar um objetivo central da política externa desse período - fazer do país um ator relevante na política internacional.

A pesquisa que originou este trabalho empreendeu a identificação, reunião e análise qualitativa de materiais bibliográficos e documentais textuais, primários e secundários. Foram considerados materiais primários aqueles produzidos pelos atores no momento de sua presença e ação em uma dada circunstância histórica. Em grande medida, são partes integrantes dessas ações e de suas decorrências imediatas e, a partir deles, é possível estabelecer uma relação direta com os eventos a serem analisados. As fontes primárias utilizadas consistiram em discursos dos presidentes da República, de ministros da Saúde e de ministros das Relações Exteriores, programas de governo, acordos internacionais firmados pelo Brasil e relatórios dos Ministérios da Saúde e das Relações Exteriores, além de publicações da Agência Brasileira de Cooperação, da Assessoria de Assuntos Internacionais em Saúde, da Fundação Oswaldo Cruz e da Organização das Nações Unidas. Nos documentos da área de política externa, o estudo buscou identificar as ocorrências e o sentido atribuído às menções ao tema da saúde. Nos documentos provenientes das autoridades em saúde, por sua vez, foram observados o registro e o grau de relevância atribuídos às atividades internacionais. Buscou-se também identificar elementos que evidenciassem o processo de institucionalização da saúde como tema da política externa brasileira.

Como fontes secundárias, por sua vez, foram considerados os materiais que discorrem sobre os eventos e processos que estão sendo observados. Apresentam distanciamento temporal, tendendo mais fortemente à produção de narrativas e análises a posteriori, ou reúnem informações que já foram processadas por outros estudiosos e configuram parte de um acervo de conhecimentos acerca de um dado tema (Sá-Silva, Almeida, Guindani, 2009). A análise dos documentos oficiais foi realizada a partir das contribuições de literatura secundária especializada e variada no que concerne à emergência de questões como direitos humanos, meio ambiente e saúde, entre outros temas da política internacional; à análise de política externa e à evolução recente da diplomacia brasileira, assim como o lugar, nela atribuído, à saúde; e às transformações experimentadas por estruturas 
organizacionais relevantes para os objetivos propostos, como o Ministério das Relações Exteriores, o Ministério da Saúde e suas agências. Essas fontes incluíram a literatura referente à Relações Internacionais, Saúde Global, Diplomacia em Saúde e Política Externa Brasileira. Essas referências foram identificadas mediante levantamento não sistemático. São obras monográficas, capítulos de coletâneas e artigos publicados em periódicos internacionais e nacionais, como The Lancet, International Organization, Revista Eletrônica de Comunicação, Informação \& Inovação em Saúde, Cadernos de Saúde Pública, Revista Brasileira de Política Internacional e Contexto Internacional, além de obras de literatura clássica e recente, de autores como Cervo \& Bueno, Vigevani \& Cepaluni e David Fidler, entre outros.

Analisando o tratamento formal do tema da saúde na agenda de política externa brasileira, este artigo contribui para o conhecimento acerca do diálogo entre diplomacia e saúde no país, tema que, apesar do crescente interesse na área de Relações Internacionais e nos estudos multidisciplinares sobre saúde global e diplomacia em saúde, ainda conta com pouca atenção no meio acadêmico brasileiro.

\section{0 contexto internacional e o objetivo da política externa brasileira}

O fim da Guerra Fria e a intensificação da globalização marcam a configuração de uma nova realidade internacional. A influência da ideologia neoliberal, a formação de blocos econômicos, o crescimento das assimetrias entre o centro do capitalismo e sua periferia, o desenvolvimento de economias emergentes, o diversificado fluxo de informações, a intensificação das interações temporais e espaciais e o crescimento da sociedade civil organizada são algumas das mudanças que caracterizam esse cenário. Na década de 1990, a política externa brasileira buscava se adaptar a esse novo contexto. Novos temas, tais como meio ambiente, direitos humanos e saúde; e novos atores, como organizações não governamentais, assim como novos espaços de diálogo multilateral, influenciavam a condução da política internacional, exigindo do Brasil a atualização de sua atuação nesse cenário. Assim, a diplomacia brasileira passou a incentivar o diálogo entre desenvolvimento e temas globais, como demonstram as participações na Conferência sobre Meio Ambiente e Desenvolvimento (Rio-92), na Conferência Mundial sobre Direitos Humanos de Viena (1993) e nos debates da Organização Mundial do Comércio - OMC (Cervo, Bueno, 2011). 
A globalização reafirmou a articulação entre saúde e política externa de forma significativa, oferecendo novos atores, mecanismos e espaços de relacionamento. Permitiu o fortalecimento da percepção de que as questões de saúde exigiam iniciativas de escopo global, uma vez que esse era o caráter das ameaças às condições de saúde das populações. A partir desse reconhecimento, a saúde ganhou importância nos processos de formulação de políticas externas, sendo considerada um instrumento significativo para a promoção de interesses e princípios nacionais na política internacional. Essa nova articulação pode ser observada por meio de algumas constatações, entre outras: a) os acordos de governança adotados pela OMS, como o Regulamento Internacional em Saúde (2005) e a Convenção-Quadro de Controle do Tabaco (2003); b) os novos mecanismos, iniciativas e parcerias em saúde global, como o Fundo Global de Combate à aids, Tuberculose e Malária e a Aliança Global para Vacinas e Imunização (GAVI); c) a proliferação de atores atuantes nessa área, incluindo países emergentes e organizações governamentais e não governamentais importantes para as questões de saúde (Fidler, 2009). Entre 1995 e 2010, as condições de saúde no mundo eram inegavelmente desafiadoras e, apesar de alguns resultados positivos, as políticas em saúde ainda demandavam incontáveis esforços internacionais e engajamento nas questões de acesso a medicamentos e serviços, fortalecimento de sistemas de saúde e capacitação profissional em saúde, entre outras.

Nesse contexto, se dava a atuação internacional do Brasil em defesa da saúde. Discutir a saúde em fóruns globais, desenvolver e apoiar projetos duradouros na área, promover parcerias e contribuir para abordagens inovadoras no combate a doenças eram formas de tratar a saúde de maneira formal e estratégica, fortalecendo a sua presença na diplomacia brasileira que, dessa forma, tinha na saúde um instrumento valioso para o alcance de uma atuação internacional relevante e de destaque. Entre 1995 e 2010, a política externa brasileira lidou com a saúde como um direito humano absoluto, que renovava a agenda diplomática diante do novo cenário internacional do pós Guerra Fria e era fundamental para o discurso de progresso e equidade internacionais que se desenvolvia. As percepções dos governos de Fernando Henrique Cardoso (FHC) e Luiz Inácio Lula da Silva divergiam sobre as possibilidades do cenário internacional e a dimensão dos recursos de poder brasileiros, mas convergiam no objetivo de que o país tivesse uma atuação mais relevante na política internacional.

Em pesquisa realizada, em 2001, por Amaury de Souza, autoridades governamentais, líderes de organizações não governamentais, empresários, 
acadêmicos e jornalistas, num total de 149 entrevistados, defenderam o papel de liderança do Brasil no sistema internacional, o que seria respaldado pelo território de dimensões continentais e pela competência da sua diplomacia. Cerca de $90 \%$ dos participantes declararam que, nos dez anos seguintes, a influência internacional do país seria ainda maior, reafirmando essa aspiração (Souza, 2002)5. Entre 1995 e 2010, a atualização da agenda de política externa, o diálogo com parceiros diversificados, o fortalecimento da capacidade de negociação, as contribuições políticas para as discussões globais e a tendência a conciliar divergências internacionais reafirmavam o objetivo de ambos os governos de aumentar sua influência.

\section{Governo Fernando Henrique Cardoso: a participação como estratégia de política externa}

É possível pensar a política externa brasileira do governo FHC como um tipo de atualização do país frente aos regimes e normas internacionais vigentes, a partir da qual o país poderia vir a influenciar o debate global, desenvolvendo uma participação propositiva na política internacional e contribuindo para a formação e a regulamentação da nova ordem internacional. Esse governo considerava o Brasil como um país de poderes intermediários e que, por isso, não deveria assumir grandes responsabilidades ou riscos excessivos no cenário internacional, percebido como constrangedor e de significativas assimetrias de poder. A atuação deveria ser moderada, conciliatória, seguidora do Direito Internacional, ativa nos fóruns globais, defensora do multilateralismo e coerente com os regimes internacionais (Vigevani, Oliveira, 2003; Pinheiro, 2004). A orientação central era a de abrir o Brasil ao mundo, intensificando a integração regional, especialmente na América do Sul, diversificando parceiros nas relações bilaterais, sobretudo com os países desenvolvidos, e atuando nos espaços multilaterais, principalmente na OMC. Assim, buscava-se, segundo tal lógica, garantir autonomia nacional, respaldo para os interesses brasileiros, credibilidade e confiança no sistema internacional.

5 Segundo Lima (2005, p. 8), a aspiração brasileira por participação ativa na política internacional é constitutiva da própria identidade nacional, “já que a percepção que as elites têm da identidade nacional constitui o substrato conceitual de sua projeção externa, pautada principalmente no desejo de exercer um papel protagônico”. Tanto a percepção de identidade como a expectativa de liderança se desenvolvem a partir da consideração de que território continental, grande população, economia diversificada, dez vizinhos contíguos e uniformidade cultural e linguística fazem do Brasil um "grande país” com um "grande papel” a desempenhar no cenário internacional, sendo esse, portanto, o objetivo central de sua política externa. 
Nesse período, o cenário internacional era visto como um ambiente desfavorável, no qual a diplomacia brasileira deveria atuar a longo prazo, buscando adaptar-se às mudanças e fortalecendo o diálogo multilateral como padrão de ação coletiva (Vigevani, Oliveira, 2003). Em vista da alegada comunhão de valores entre o Brasil e o mainstream internacional, e apesar de possuir poderes apenas medianos, o país não poderia se eximir da participação nas discussões globais. Essa postura é interpretada por Vigevani \& Cepaluni (2007) como baseada numa lógica de “autonomia pela participação”, pela qual o Brasil desenvolveria uma agenda diplomática proativa, ampliando o controle sobre o seu destino, reafirmando o poder nacional e colaborando para a regulamentação das relações internacionais, nas mais diversas áreas. Assim, a inserção do Brasil no sistema internacional, como um ator confiável, estável, seguidor das regras e regimes internacionais e, ao mesmo tempo, influente na formulação dos princípios e normas da ordem internacional, consistiria no objetivo central da política externa.

Já de acordo com Cervo (2003), é possível identificar quatro grandes eixos na política externa brasileira do governo de FHC: a) o multilateralismo como a força capaz de fomentar a formulação mundial de regras justas, transparentes e respeitadas por todos, que estimulariam um comércio internacional sem barreiras, a proteção do meio ambiente aliada ao desenvolvimento e um regime de segurança regido pela Organização das Nações Unidas (ONU); b) o regionalismo, pelo qual o Brasil iria alcançar compensações econômicas e reforçar o seu poder político; c) a relação com os Estados Unidos, que ocorreria de forma ambígua, com a alternância entre certa subserviência na dimensão econômica e confronto na dimensão política; e d) o diálogo com a União Europeia, o qual, mesmo sem resultados concretos, buscaria uma zona de livre comércio a fim de equilibrar as relações com os Estados Unidos no que concerne à Área de Livre Comércio das Américas (ALCA), proposta pelo presidente Bill Clinton em 1994. Esses eixos teriam caracterizado a década de 1990 como a década das ilusões, uma vez que, na prática, ao invés de ampliar as margens de atuação do Brasil no mundo, as teria limitado.

\section{Governo Luiz Inácio Lula da Silva: a transformação como estratégia de política externa}

No contexto de uma nova fase da globalização, na qual a ideologia neoliberal perdia importância na periferia e os países emergentes fortaleciam seus mecanismos de articulação entre si (IBAS, G-20, BRICS), o governo do presidente Lula da 
Silva atualizava a agenda da política externa brasileira investindo na defesa da redistribuição do poder nas relações internacionais. O cenário internacional representava um espaço de oportunidades para o fortalecimento da capacidade negociadora do Brasil, para a diversificação de suas parcerias, a criação de fóruns internacionais, a mediação das relações entre países desenvolvidos e em desenvolvimento e a defesa de temas sociais nas discussões globais (Cervo, Bueno, 2011). A diretriz central era, portanto, aumentar o espaço de atuação do Brasil no mundo. $\mathrm{O}$ aprofundamento da integração sul-americana, o estreitamento das relações com a África e a defesa da reforma do Conselho de Segurança da ONU foram algumas das medidas que visavam a construção de uma ordem internacional mais igualitária e justa.

Cervo (2003) identifica quatro grandes linhas de força na condução da política externa brasileira no governo do presidente Lula da Silva: a) recuperação do universalismo e do bilateralismo, a partir de parcerias estratégicas com a África, a China, o Japão e a Rússia e da reivindicação de um assento permanente no Conselho de Segurança da ONU; b) relação com a América do Sul, considerada o espaço natural de afirmação dos interesses brasileiros, reforço das economias da região, autonomia na dimensão política e rejeição a intervenções externas em caso de problemas de segurança regional; c) fim de dependências estruturais e promoção de uma inserção interdependente, a fim de combater a vulnerabilidade externa e amenizar os efeitos negativos da globalização assimétrica sobre o Brasil e os países em desenvolvimento e; d) preservação do acumulado histórico da diplomacia brasileira, assegurando o respeito aos princípios de autodeterminação, não intervenção, pacifismo e desenvolvimento.

No mesmo sentido, Vigevani, Cepaluni (2007) identificam algumas diretrizes adotadas na condução da política externa do governo de Lula da Silva, como a busca por maior equilíbrio no sistema internacional, o fortalecimento do intercâmbio econômico, financeiro, tecnológico e cultural por meio da diplomacia e a participação influente do país em negociações multilaterais e bilaterais. Esses mesmos autores atribuem ao governo Lula da Silva a busca de "autonomia pela diversificação”, pela qual o governo procurava formas autônomas de relacionamento internacional, capazes de envolver diversos parceiros, especialmente os do Sul, em múltiplos arranjos, e de permitir distintas opções estratégicas para a diplomacia brasileira, o que aumentaria a sua capacidade negociadora, equilibraria as relações com o Norte e aumentaria o protagonismo internacional do país. 
A aspiração brasileira de democratizar as relações internacionais é discutida por Parola (2007, p. 30), que atribui à política externa do governo do presidente Lula da Silva a ideia de "pragmatismo democrático”, considerando-a uma "política que articula a promoção de valores inspirados pela própria cidadania com a capacidade de atuar de modo não dogmático em defesa dos interesses nacionais e da construção de uma ordem justa”. Nesse sentido, é possível dizer que a política externa brasileira desse governo era guiada por valores que consideravam o país como uma potência em construção e defendia uma perspectiva humanista sobre a ordem internacional, na qual os compromissos de justiça, igualdade e democracia deveriam ser buscados pelos países.

Apesar das diferenças de ênfase e mesmo de princípio na política externa dos governos de FHC e Lula da Silva, o Brasil desenvolveu, como veremos a seguir, uma diplomacia propositiva e influente no debate internacional em saúde, capaz de formular diretrizes para a regulação internacional, apresentar ao mundo as experiências nacionais e estabelecer escolhas que reforçavam seu papel de liderança no cenário internacional.

\section{A atuação internacional do Brasil em saúde}

De forma ainda incipiente e enfrentando as dificuldades de comunicação e troca de conhecimento, entre 1995 e 1999, o Brasil buscava parcerias com China, Índia e Rússia na área da saúde (Rubarth, 1999). Em 1995, o país participou, em Copenhague, do primeiro grande evento internacional sobre o tema do desenvolvimento social, a Cúpula Mundial sobre Desenvolvimento Social, que estabeleceu compromissos que envolviam a erradicação da pobreza, o respeito à dignidade humana e o acesso universal à educação e à saúde, entre outros. No mesmo ano, o país contribuiu para a discussão internacional em saúde ao participar da IV Conferência Mundial sobre a Mulher, em Pequim, na qual a extensa delegação brasileira foi composta por diplomatas e um representante do Ministério da Saúde, entre outros atores, que discutiram as desigualdades no acesso aos serviços de saúde e a violência contra a mulher (Alves, 2001). Ainda no âmbito da Organização das Nações Unidas, o lançamento dos Objetivos de Desenvolvimento do Milênio, em 2000, chancelados pelos 191 membros da Organização, também representou um momento importante para a discussão internacional em saúde e a política externa brasileira nessa área. Três dos oito 
objetivos referem-se explicitamente ao tema da saúde, na defesa da promoção da saúde das gestantes, da redução da mortalidade infantil e do combate à aids, malária e outras doenças (BRASIL, 2014).

A participação do Brasil nos grandes debates internacionais em saúde também aumentou de forma significativa, inclusive em fóruns como o da OMC. Em fevereiro de 2001, acusado pelos Estados Unidos de violar o Acordo TRIPS, o Brasil mobilizou uma série de atores internacionais em benefício das demandas dos países em desenvolvimento, enfatizando as necessidades social e econômica de se preservar a disponibilidade de medicamentos genéricos para o tratamento de pessoas com HIV/Aids nesses países e destacando os preços exorbitantes praticados pela indústria farmacêutica norte-americana. O país obteve o apoio de vários países; da opinião pública internacional; de importantes organizações não governamentais, como Médicos Sem Fronteiras e Oxfam Internacional; da ONU; e da OMS, todos em defesa do acesso a medicamentos (Ponte, 2012). Meses depois, em junho de 2001, os Estados Unidos retiraram sua queixa na OMC, em troca da garantia de que seriam notificados, com antecedência, caso qualquer produto patenteado ou licenciado por empresas norte-americanas fosse licenciado compulsoriamente pelo Brasil (Souza, 2011). O episódio conhecido como "contencioso das patentes farmacêuticas" ilustraria a forte influência brasileira no debate internacional em saúde, que mobilizava atores e estruturas de governança internacionais importantes (Cepaluni, 2005).

Em abril de 2001, foi aprovada, na Comissão de Direitos Humanos da ONU, a resolução "Acesso a Medicamentos no Contexto de Pandemias como HIV/Aids", que apresentava o acesso a medicamentos essenciais como um direito humano à saúde. Foi proposta pela delegação brasileira e aprovada por 52 países. Em seguida, na Assembleia Mundial da Saúde (AMS), em maio do mesmo ano, o país reafirmava a necessidade de redução dos custos dos medicamentos antirretrovirais, defendia a produção de genéricos em países pobres e a elaboração de um fundo internacional para o financiamento de projetos de combate à aids nesses países. A "Resposta Global ao HIV/Aids" e a "Estratégia de Medicamentos da OMS" foram duas resoluções que resultaram das propostas brasileiras (Souza, 2011). Em novembro de 2001, na IV Conferência Ministerial da OMC, em Doha, o Brasil liderou as críticas ao Acordo TRIPS, defendendo a flexibilização de alguns de seus termos e a proteção da saúde pública diante dos interesses econômicos dos grandes laboratórios. Novamente, em consonância com o debate internacional, o país contou com o apoio de ativistas de inúmeros países. Com a liderança 
brasileira, a Conferência produziu a “Declaração sobre o Acordo TRIPS e a Saúde Pública”, que formalizou a busca de mecanismos que protegessem a saúde pública, promovessem o acesso a medicamentos, reduzissem os efeitos negativos do Acordo TRIPS e colaborassem para a difusão de conhecimentos (Souza, 2011).

A participação do Brasil na elaboração da Convenção-Quadro de Controle do Tabaco é outro destaque de sua atuação internacional em saúde. Com início em 2000 e reunindo representantes dos Estados-membros da OMS, de organizações internacionais e de dezenas de organizações não governamentais, as reuniões do Órgão de Negociação Intergovernamental, responsável pela elaboração do texto da Convenção-Quadro, foram presididas pelos embaixadores brasileiros Celso Amorim e Luiz Felipe Correa durante todo o período de elaboração do texto. A aprovação oficial durante a AMS de 2003 dava origem ao primeiro tratado internacional de iniciativa da OMS com a missão de reduzir mortes e doenças ligadas ao tabaco em todo mundo (Toscano, 2006).

Seguindo as discussões sobre os preços de antirretrovirais patenteados, o presidente Lula da Silva promulgou, em 2003, o Decreto $n^{\circ} 4.830$, que permitia a importação de medicamentos genéricos de produtos licenciados compulsoriamente sempre que a produção doméstica fosse considerada inviável, obrigando o detentor da patente a apresentar toda a informação necessária para a produção. Por meio desse decreto, o poder de barganha brasileiro diante das grandes companhias farmacêuticas, como Merck, Roche, Abbott e Gilead, foi fortalecido, e significativas vitórias foram alcançadas no que concerne à compra de medicamentos (Souza, 2011).

Na 56 AMS, também em 2003, o Brasil defendeu a ideia de que a OMS deveria dispor de um mandato que lhe permitisse avaliar as implicações, para a saúde pública, da proteção dos direitos de propriedade intelectual, como acordados no Acordo TRIPS. Nesse contexto, o país votou a favor da Resolução N ${ }^{0} 56.27$, “Direitos de Propriedade Intelectual, Inovação e Saúde Pública”, que reivindicava que a OMS adotasse medidas para a redução dos efeitos negativos dos acordos internacionais de comércio (Souza, 2011). Já na 57 a AMS, em 2004, foi aprovada a Resolução $N^{\circ}$ 57.14, que reafirmou o direito dos países membros da OMS de utilizar as flexibilidades do TRIPS e de acordos de comércio regionais e bilaterais, destacando a urgência do acesso a medicamentos.

Expressão da crescente importância do tema na agenda diplomática do país, a assinatura, em julho de 2005, do Protocolo de Intenções entre o ministro das Relações Exteriores e o ministro da Saúde (BRASIL, 2005), instituindo coordenação 
entre os dois órgãos para o aperfeiçoamento da cooperação técnica em saúde prestada pelo Brasil a países em desenvolvimento, representou um marco para a relação entre os dois ministérios e para a atuação internacional do Brasil em saúde. A partir de 2005, a relação com os Países Africanos de Língua Oficial Portuguesa foi fortalecida e, em 2008 e 2009, ocorreram as Reuniões dos Ministros de Saúde da Comunidade de Países de Língua Portuguesa, que permitiram a formulação e a aprovação das parcerias em saúde, que previam a construção e o fortalecimento de iniciativas "estruturantes", o desenvolvimento de políticas de vigilância epidemiológica e o reforço dos sistemas de saúde desses países, entre outras atividades (Almeida et al., 2010). É válido ressaltar que, durante o governo do presidente Lula da Silva, a África apresentou o maior número de iniciativas em saúde, totalizando 53 atos bilaterais com 22 países (BRASIL, 2010a). Em 2006, o Brasil, ao lado de Chile, França, Noruega e Reino Unido, na Assembleia Geral da ONU, se tornava membro fundador da UNITAID, uma iniciativa global que arrecada recursos para o diagnóstico, a prevenção e a compra de medicamentos para o tratamento da aids, da malária e da tuberculose em países em desenvolvimento.

Outro documento de significativa relevância, nesse breve histórico de medidas brasileiras que promoveram sua participação no debate internacional em saúde, foi assinado na Noruega, em 2007, envolvendo, além do Brasil, os ministros de Relações Exteriores da França, Indonésia, Noruega, África do Sul, Tailândia e Senegal. Pela Declaração de Oslo, esses ministros defendem explicitamente a saúde como um tema de política externa e de importância fundamental para a agenda do desenvolvimento, clamando por uma ação global em benefício da saúde (Amorim et al., 2007).

Em março de 2007, o Ministério da Saúde criou o programa "Mais Saúde — Direito de Todos", para o período de 2008 a 2011. Um dos seus sete eixos de trabalho consiste na cooperação em saúde com outros países, a fim de fortalecer a atuação internacional do Brasil, especialmente nos programas da ONU, e estreitar o diálogo com o MRE, colaborando para o desenvolvimento dos sistemas de saúde dos países parceiros, apoiando, inclusive, o estabelecimento de uma rede pan-amazônica de cooperação em ciência, tecnologia e inovação e a formação profissional de técnicos em saúde. Um dos resultados desse programa consistiu no desenvolvimento - pela Rede Brasileira de Bancos de Leite Humano, coordenada pelo Ministério da Saúde - de iniciativas que proporcionaram a implantação de 21 bancos de leite humano em seis países, entre 2007 e 2009 (BRASIL, 2010b). 
A Resolução WHA60.30, "Saúde Pública, Inovação e Propriedade Intelectual”, aprovada na $60^{\mathrm{a}}$ AMS de 2007, resultou, em grande medida, dos esforços brasileiros para que a OMS assumisse o compromisso de apoiar tecnicamente os países que desejassem utilizar as flexibilidades do Acordo TRIPS (Souza, 2011). Nesse ano, o país também emitiu licença compulsória para o antirretroviral Efavirenz, da Merck, sendo o primeiro caso de licenciamento compulsório de um antirretroviral no continente americano.

Em 2008, na Cúpula da Costa do Sauípe, foi criado o Conselho Sul-Americano de Saúde, pelo qual a União das Nações Sul-Americanas expandia o programa de cooperação em saúde na região. Suas atividades previam o estabelecimento de um escudo epidemiológico nesses países, o desenvolvimento de sistemas de saúde universais, o acesso universal a medicamentos, a capacitação de recursos humanos, entre outras atividades (Almeida et al., 2010). No âmbito da Unasul, o país liderou o processo de decisão pela criação, em 2009, e pela instalação, no Rio de Janeiro, do Instituto Sul-Americano de Governo em Saúde (ISAGS), um centro de altos estudos e de debate dos temas da saúde sul-americana.

Seguindo na defesa do acesso a medicamentos, o Brasil, junto com os parceiros do IBAS e com o apoio de vários países em desenvolvimento, aprovou, em 2009, no Conselho de Direitos Humanos da ONU, a Resolução Nº 6/29, que reconhece o acesso a medicamentos como elemento fundamental para o alcance de altos padrões de saúde física e mental e destaca o papel dos Estados para a garantia da oferta de medicamentos (Souza, 2011).

O número e variedade dessas iniciativas, no período estudado, que transitam da disputa de contenciosos no terreno das patentes de medicamentos à oferta de cooperação técnica em um número expressivo de países, de pelo menos dois continentes, passando pela celebração de acordos, a presença ativa em fóruns internacionais e o eventual protagonismo na criação de algumas dessas instâncias, sinalizam para um contínuo aumento da importância do tema da saúde na agenda internacional do país. O presidente FHC, seguindo sua política de autonomia pela participação, fortaleceu uma política inovadora de acesso a medicamentos para a aids, o que influenciou países desenvolvidos e em desenvolvimento. Associando a saúde ao tema de direitos humanos, esse governo atualizava a diplomacia brasileira diante das mudanças do cenário internacional pós Guerra Fria, dirimindo divergências internacionais e influenciando o debate global em saúde. No governo de Lula da Silva, o país contribuiu para as discussões globais em saúde por meio de sua experiência na área e sua disposição para desenvolver e executar projetos 
internacionais relacionados, especialmente os que atendessem às necessidades das populações dos países em desenvolvimento. Nesse sentido, o presidente deu continuidade e promoveu a política externa para a aids, a defesa de acesso a medicamentos e redução de preços para o tratamento de doenças negligenciadas, como malária e tuberculose, e o discurso que aliava a saúde ao tema de direitos humanos. A saúde das populações era um dever global que o Brasil deveria cumprir por meio de diversas parcerias internacionais e pela participação nas instituições globais, como a Organização Mundial da Saúde e a OMC.

Tanto pela promoção do direito internacional e da participação brasileira nos regimes globais, como mostra o período de 1995 a 2002, quanto pelo fortalecimento do diálogo com os países em desenvolvimento e a reafirmação da liderança brasileira no Sul, como visto entre os anos de 2003 a 2010, os presidentes brasileiros seguiram uma linha de ação pela qual o país influenciou as discussões internacionais e apresentou ao mundo sua experiência, colaborando para a regulação internacional em saúde e a execução de projetos de cooperação nessa área.

Na literatura acadêmica, há autores que defendem que as mudanças entre as políticas externas dos presidentes FHC e Lula da Silva foram significativas (Cervo, Bueno, 2011; Parola, 2007). Do outro lado, estão aqueles que afirmam que o presidente petista apenas seguiu as linhas de atuação estabelecidas por seu antecessor (Pecequilo, 2008). Há ainda uma corrente em posição intermediária que atribui à gestão do presidente Lula da Silva ajustes, mudanças e continuidades (Vigevani, Cepaluni, 2007; Vaz, 2004; Saraiva, 2007). É possível afirmar que essas classificações variam de acordo com os momentos e objetos de análise. O tema da saúde, em específico, não só estava presente na agenda da política externa brasileira em ambos os governos, como também essa presença se desenvolveu em um processo crescente de institucionalização, tanto em termos político-administrativos, quanto no nível do discurso, o que oferece uma dimensão de continuidade entre eles, respeitando as diferenças, sem dúvida existentes, nos esforços diplomáticos e linhas de atuação de cada governo em uma outra ordem de iniciativas.

\section{A institucionalização da saúde na política externa brasileira}

Alcázar (2005) considera que a institucionalização do tema da saúde na agenda da política externa brasileira é resultado de vários fatores, como a implantação do Sistema Único de Saúde (SUS); o fortalecimento do Ministério da Saúde como ator político, que passou a participar dos encontros da OMC e da Assembleia 
Geral da ONU e de outros fóruns não relacionados diretamente à saúde, além das reuniões da OMS e da Organização Pan-Americana da Saúde (OPAS); as melhores disponibilidades orçamentárias para esse órgão; e a emergência dos temas sociais nas discussões internacionais.

Por outro lado, a intenção de participar do debate internacional em saúde também se materializou por meio de um processo de institucionalização no tratamento desse tema pela política externa brasileira, evidenciado pelas modificações no nível político-administrativo e no discurso oficial. Em favor do fortalecimento da atuação internacional do Brasil no campo da saúde e, portanto, de sua participação nos fóruns globais e de influência na formulação de políticas, foi necessário introduzir mudanças nas estruturas organizacionais do MRE e do Ministério da Saúde, em seus mecanismos de diálogo e atuação, além de ser indispensável que o país afirmasse seu compromisso internacional com o tema por meio de declarações oficiais das autoridades brasileiras.

Em 1995, o Ministério das Relações Exteriores criou o “Departamento de Direitos Humanos e Temas Sociais”, que seria responsável pela participação do Brasil nas conferências sociais internacionais da década de 1990. Alterava-se, assim, a estrutura da Subsecretaria Geral Política I desse ministério, que não mais trataria dos temas sociais apenas como parte subordinada das atribuições de uma divisão (Puntigliano, 2008). No mesmo sentido, uma década depois, a Agência Brasileira de Cooperação (ABC), vinculada ao MRE, e possuindo as funções principais de operacionalizar a política de cooperação técnica internacional do país e de elaborar e monitorar os projetos de cooperação prestados e recebidos pelo Brasil, passou a adotar, em 2006, uma divisão temática, não mais geográfica, para sua organização interna. Em 2007, seria instituída a Coordenação-Geral de Cooperação em Saúde, Desenvolvimento Social, Educação e Formação Profissional, que passaria a orientar as contribuições do MRE para os projetos internacionais do país em saúde (ABC, 2010).

Em relatório próprio, divulgado em 2009, a Assessoria de Assuntos Internacionais em Saúde (AISA), vinculada ao Ministério da Saúde, explicitou a necessidade de reorganização político-administrativa desse ministério em nome das contribuições à formulação de política externa na área da saúde. Nesse relatório, a assessoria declarou que as ações internacionais do Ministério da Saúde deveriam seguir os propósitos maiores da política externa brasileira, em diálogo estreito com os seus órgãos vinculados, como a Fiocruz e a Anvisa, e com o MRE. Como também defendido pela ABC, o diálogo entre os dois ministérios deveria incluir a troca de profissionais e a criação de mecanismos de articulação, 
em benefício do fortalecimento da atuação diplomática do Brasil no mundo, no qual as novas agendas diplomáticas requeriam a troca de expertise entre diversas áreas especializadas (BRASIL, 2009a).

O relatório também aponta que, pela resolução "Saúde e Relações Internacionais: vinculações com o desenvolvimento sanitário nacional do Comitê Executivo da Opas/OMS", assinada em junho de 2008, o país reafirmou a ideia de interação entre as "autoridades sanitárias" e as "autoridades encarregadas da política exterior", por meio do reforço dos mecanismos institucionais de diálogo e da inclusão tanto do tema da saúde na profissionalização dos diplomatas quanto dos temas de relações internacionais na formação das autoridades em saúde (BRASIL, 2009a, p. 5).

O mecanismo de transferência internacional de recursos, chamado Termo de Cooperação No 41 (TC-41), assinado em 2005 pelo Ministério da Saúde e a Opas/OMS, também estimulou a parceria entre o Ministério da Saúde e o MRE na elaboração das ações internacionais em saúde, na medida em que as partes signatárias reconheciam expressamente a necessidade de colaboração e articulação entre as duas pastas (BRASIL, 2006). Esse mecanismo pressupunha que o país se constituía em referência para a cooperação internacional na área da saúde e tinha como objetivo central promover a troca de experiências, tecnologias e conhecimentos pelas instituições brasileiras no âmbito da cooperação Sul-Sul. As atividades previstas incluíam pesquisa básica, ações em saúde coletiva, produção de insumos, análise de políticas públicas e história da saúde, entre outras (Pires-Alves; Paiva; Santana, 2012).

Se as informações acima apontam para os arranjos de natureza político-administrativa que foram ao mesmo tempo causa e efeito da relevância do tema da saúde na agenda da política externa brasileira, no nível do discurso oficial devem ser consideradas todas as referências a eventos internacionais em saúde disponibilizados pelos websites do Ministério das Relações Exteriores e do Ministério da Saúde. Os resultados mostram então a proeminência da participação dos presidentes FHC e Lula da Silva e dos responsáveis pelas pastas da saúde e das relações exteriores nos fóruns internacionais. Em todos os documentos, é possível observar a importância conferida, por essas autoridades, ao tema da saúde na diplomacia brasileira em sua busca pelo fortalecimento do país como ator político internacional relevante. Notou-se também o apoio à parceria entre o MRE e o Ministério da Saúde, mencionada como responsável por parte significativa do sucesso da atuação internacional do país em saúde. Já a variedade de fóruns em que os discursos foram proferidos pode ser atribuída ao reconhecimento, pelas 
autoridades brasileiras, do diálogo da saúde com outras dimensões da política externa, como segurança, desenvolvimento e direitos humanos.

Assim, nas Assembleias-Gerais das ONU, na Cúpula das Américas, nas Assembleias Mundiais da Saúde, na Cúpula África-América do Sul ou em colóquios e congressos internacionais sobre saúde desde 2001, o Brasil declarou o seu apoio a políticas de acesso a medicamentos e de tratamento de doenças negligenciadas, como malária e tuberculose; discorreu sobre sua experiência no tratamento da aids; reafirmou o seu compromisso com os países em desenvolvimento e o combate à pobreza; ressaltou a necessidade de expansão da produção de conhecimento; e defendeu a equidade, a melhoria dos sistemas de saúde ao redor do mundo e a capacitação dos profissionais dessa área. A seguir, apresentamos alguns trechos de discursos oficiais.

Nos dois primeiros, o presidente FHC, em tom conciliatório e de acordo com um estilo de política externa moderado, discorreu sobre a internacionalização da experiência brasileira no tratamento da aids e sobre a posição do país em defesa do acesso a medicamentos. A partir de ambos os exemplos, constata-se que o Brasil pretendia assumir um papel de ator influente no debate internacional sobre o tema da saúde.

Primeiramente, em abril de 2001, no Canadá, por ocasião da III Reunião de Cúpula das Américas, FHC declarou:

Pelo diálogo e pela cooperação poderemos responder a desafios contemporâneos, como o de assegurar aos que sofrem com a AIDS tratamento ao menor custo possível. Como demonstra o êxito do programa brasileiro nesse campo, já dispomos de meios para aumentar a esperança e melhorar a vida dos que têm o vírus HIV. Não podemos deixar de utilizá-los, e de utilizá-los em toda a escala, inclusive cooperando com outros países em desenvolvimento afetados por essa doença. (BRASIL, 2009b)

Em seguida, em novembro de 2001, na Abertura do Debate-Geral da 56 a Sessão da Assembleia-Geral das Nações Unidas, o presidente afirmou:

O Brasil, que vem liderando negociações para garantir maior acesso aos mercados e melhores condições humanitárias para o combate às doenças, buscará encontrar o ponto de equilíbrio entre a necessária preservação dos direitos de patente e o imperativo de atender aos mais pobres. Somos pelas leis de mercado e pela proteção à propriedade intelectual, mas não ao custo de vidas humanas [...] A vida há de prevalecer sobre os interesses materiais. (BRASIL, 2009b) 
No decorrer do processo de institucionalização do tema da saúde na agenda da política externa brasileira, o Brasil passaria a reconhecer o diálogo desse tema com outras dimensões da diplomacia. A consideração das epidemias como ameaças à segurança dos países pode ser observada na seguinte declaração do Ministro Celso Amorim.

Em outubro de 2003, na Cidade do México, no Debate-Geral da Conferência Especial de Segurança da Organização dos Estados Americanos sobre justiça social, o Ministro declarou:

Diretamente ou não, todas nossas sociedades sofrem os efeitos da criminalidade, da corrupção, da lavagem de dinheiro, do fácil acesso legal ou ilegal - às armas de fogo, do tráfico de menores, da delinquência pelas drogas, dos delitos ambientais, das epidemias de elevado impacto social, como a da AIDS, ela própria considerada uma ameaça à segurança internacional pelas Nações Unidas. (AMORIM, 2003)

O sentido de continuidade entre os governos de FHC e Lula da Silva, no que concerne a uma ativa atuação internacional em saúde, pode ser identificado nas ações de combate à aids. Nos dois fragmentos seguintes, o presidente Lula reafirmou o empenho internacional do Brasil no tratamento dessa doença e no compartilhamento da experiência nacional nessa área. Seguindo a defesa, iniciada nos anos de 1990, dos direitos humanos, Lula da Silva, como seu antecessor, mas em um contexto internacional diferente e formulando de forma distinta a política externa brasileira, enfrentou as ameaças das regulações de patente.

Em setembro de 2004, em Nova York, por ocasião da LIX Assembleia-Geral das Nações Unidas, o presidente Lula da Silva afirmou:

Acredito firmemente que o processo desencadeado ontem elevará o patamar da luta contra a pobreza no mundo. Na medida em que avançarmos nessa nova aliança, teremos melhores condições de cumprir as Metas do Milênio, sobretudo a erradicação da fome [...] Foi com esse espírito que África do Sul, Índia e Brasil estabeleceram, no ano passado, o fundo de solidariedade - IBAS. Nosso primeiro projeto, em Guiné-Bissau, será lançado amanhã. Também priorizamos o tema do HIV-AIDS, que tem perversa relação com a fome e a pobreza. Nosso programa de Cooperação Internacional no combate ao HIV-AIDS já opera em seis países em desenvolvimento e brevemente chegará a mais três. (BRASIL, 2008) 
Em julho de 2005, em Paris, na Abertura do Colóquio “Brasil: Ator Global” sobre o papel do Brasil no mundo globalizado, o presidente afirmou:

Um país como o Brasil não tem a opção de viver à margem dos processos globais. Dou um exemplo. Temos um programa de combate à AIDS que é mundialmente reconhecido como resposta a um dos piores dramas vividos pela humanidade em nossos dias. Realizamos, em ampla escala, a distribuição de remédios retrovirais. Mas, para que seja viável em um país com recursos escassos, esse programa depende de que os preços dos medicamentos não ultrapassem certos limites razoáveis. Torna-se essencial, portanto, estabelecer um equilíbrio entre o interesse legítimo das empresas farmacêuticas, que se beneficiam de patentes, e o interesse maior de salvar quantas vidas pudermos. (BRASIL, 2008)

O engajamento do Brasil no combate a doenças de escala global não se limitava à aids. Malária e tuberculose representavam outros desafios, citados abaixo por Celso Amorim. Independente da doença em discussão, o que predominava no discurso brasileiro era a disposição para o diálogo estreito com os países em desenvolvimento.

Em setembro de 2005, em Nova York, na LX Sessão da Assembleia-Geral das Nações Unidas, o ministro Celso Amorim declarou:

Enfrentamos, além dos desafios a que já me referi, duas crises com impacto global: a explosão pandêmica do HIV/AIDS; e as trágicas ameaças derivadas das mudanças climáticas. O Brasil continuará mobilizado para promover a implementação dos instrumentos multilaterais para combater esses flagelos [...] Ajudamos a combater a fome, a desenvolver a agricultura e, com grande empenho, a lutar contra o flagelo do HIV/AIDS em vários países irmãos do continente africano. (BRASIL, 2007)

Na busca de relevância política e participação ativa no cenário internacional, reafirmando o tema da saúde em suas posições oficiais e adaptando suas estruturas político-administrativas, o Brasil de FHC e Lula da Silva demonstrou considerar estratégico formalizar o tema da saúde em sua agenda diplomática, uma vez que isso representava a oportunidade de se tornar uma referência nas discussões globais em saúde e, consequentemente, o fortalecimento de sua presença internacional. 


\section{Conclusões}

Ao demonstrar os compromissos assumidos e as contribuições do Brasil ao debate internacional em saúde, este artigo confirmou as hipóteses de que: 1) o tema da saúde ganhou importância política na agenda da política externa brasileira a partir de 1995 e assim permaneceu até 2010 (marco temporal final desta investigação); e que 2) isso ocorreu em função do objetivo maior da diplomacia brasileira de alcançar posição de influência na política internacional. Os governos de FHC e Lula da Silva, mesmo que formuladores de distintas diretrizes de política externa, garantiram ao tema da saúde um espaço formal na agenda dessa política, entendendo que isso viabilizaria a aspiração de uma participação relevante no cenário internacional, uma vez que Estados, organizações internacionais governamentais e não governamentais de todo o mundo discutiam o tema, oferecendo um espaço amplo de atuação.

De acordo com os dados levantados, o país, nesse espaço, apresentou sua experiência no tratamento do HIV/Aids, contribuiu para a regulação internacional do consumo de tabaco, defendeu o acesso a medicamentos, atuou de modo a fortalecer os processos de formação de pessoal e da infraestrutura de saúde, em apoio aos sistemas de saúde dos países em desenvolvimento, e confirmou os esforços referentes aos Objetivos de Desenvolvimento do Milênio, aumentando sua influência no cenário internacional. Para tanto, mobilizou estruturas políticoadministrativas que possibilitariam participação ativa, constante e consistente no debate internacional, assumiu protagonismo e responsabilidades significativas em diversas ações de cooperação, assim como assumiu, em pronunciamentos oficiais nos fóruns multilaterais, o compromisso com a área da saúde. A presente pesquisa também observou que desenvolvimento, crescimento econômico, comércio, direitos humanos e ética internacional são algumas das áreas com as quais a saúde se relaciona na formulação de política externa desde o fim da Guerra Fria. Essa relação se desenvolve a partir do reconhecimento de que os problemas de saúde afetam, de alguma forma, mesmo que em graus diferentes, as funções centrais da diplomacia, como a busca de desenvolvimento econômico e de influência política, por exemplo.

O presente trabalho reúne e sistematiza informações que se encontram dispersas em documentos oficiais do Ministério da Saúde, do Ministério das Relações Exteriores e de suas respectivas agências. Dados - que nunca foram dispostos em um breve histórico ou relacionados entre si - formaram aqui os contextos 
nacional e internacional em que as áreas de saúde e política externa dialogaram durante os governos de FHC e Lula da Silva, indicando seus atores, interesses e mecanismos institucionais. Dessa forma, o trabalho reforça, para as literaturas dessas áreas, a possibilidade de interação entre elas e indica os níveis políticoadministrativo e de discurso oficial como ferramentas para o estudo dessa interação. Além disso, a pesquisa busca na literatura acadêmica as análises que ajudam a compreensão das iniciativas políticas tomadas por esses governos em saúde e política externa, corroborando a ideia de que esses temas não são exclusivos de grupos implementadores de políticas, mas também da academia, que ainda inicia sua produção nessa área em todo o mundo. Nesse sentido, o futuro da diplomacia em saúde do Brasil representa um tema amplo e importante de pesquisa.

Os resultados desse trabalho indicam como questões para estudo futuro aquelas referentes, principalmente, ao grau de institucionalização alcançado nesse processo, aos resultados efetivos das iniciativas internacionais em saúde do Brasil e à manutenção ou não da saúde como um instrumento para o alcance dos objetivos da política externa do país. São questões que requerem um refinamento das elaborações conceituais, infelizmente ainda escassas ou de pouca profundidade nesse momento; e a união de interesses, recursos de pesquisa e expertise de Relações Internacionais, Saúde Coletiva e demais Ciências da Saúde, Ciência Política e Economia, entre outras áreas, além de esforços de análise tanto da esfera acadêmica quanto da política. Dessa forma, o trabalho não se propõe a responder perguntas clássicas da literatura de política externa sobre os governos de FHC e Lula da Silva ou questões frequentes no debate em saúde, mas incentivar o diálogo entre essas duas áreas e indicar alguns temas pelos quais isso pode acontecer, apontando as dificuldades teóricas para tanto.

\section{Referências}

AGÊNCIA BRASILEIRA DE COOPERAÇÃO. Via ABC, Ministério das Relações Exteriores, 2010. Disponível em: < www.abc.gov.br/intranet/Sistemas_ABC/siteabc/documentos/ viaABC baixa.pdf $>$. Acesso em: 02 jan.2014.

ALCÁZAR, Santiago. A inserção da saúde na política exterior brasileira. Brasília: Instituto Rio Branco, Ministério das Relações Exteriores, Curso de Altos Estudos, p. 1-205, 2005. ALMEIDA, Celia et al. A concepção brasileira de "cooperação Sul-Sul estruturante em saúde”. Revista Eletrônica de Comunicação, Informação e Inovação em Saúde, v. 4, n. 1, p. 25-35, 2010. 
ALVES, J.A.Lindgren. Relações Internacionais e Temas Sociais: a década das conferências. Brasília: IBRI, 2001.

AMORIM, Celso. Discurso do Ministro das Relações Exteriores, Embaixador Celso Amorim, pronunciado, em 28 de outubro de 2003, no México, no debate geral da Conferência Especial de Segurança, no âmbito da OEA. Disponível em: < http://www.itamaraty. gov.br/pt-BR/discursos-artigos-e-entrevistas-categoria/7605-discurso-do-ministrodas-relacoes-exteriores-embaixador-celso-amorim-pronunciado-em-28-de-outubro-de2003-no-mexico-no-debate-geral-da-conferencia-especial-de-seguranca-no-ambitoda-oea > . Acesso em: 22 jan. 2015.

AMORIM, Celso et al. Oslo Ministerial Declaration - Global health: a pressing foreign policy issue of our time. The Lancet, v. 369, n. 9570, p. 1373-1378, 2007.

BRASIL. Extrato do $41^{\circ}$ Termo de Cooperação e Assistência Técnica ao ajuste complementar. Diário Oficial da República Federativa do Brasil, Seção 3, 10 jan. 2006.

BRASIL. Ministério das Relações Exteriores. Balanço da Política Externa 2003 -2010. Brasília, MRE, 2010a.

BRASIL. Ministério da Saúde. Participação do Ministério da Saúde no Cenário Internacional da Saúde: Ciclo de debates: Assessoria Internacional do Ministério da Saúde. Brasília: Ministério da Saúde, 2009a.

BRASIL. Ministério da Saúde. Secretaria-Executiva. Mais Saúde: Direito de Todos 2008-

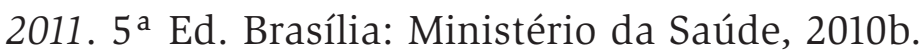

BRASIL. Ministério da Saúde. Ministério das Relações Exteriores. Protocolo de Intenções entre o Ministério das Relações Exteriores e Ministério da Saúde. Brasília: Ministério da Saúde, 2005.

BRASIL. Ministério da Saúde. O Brasil e os ODM, 2014. Disponível em: < http://www. odmbrasil.gov.br/o-brasil-e-os-odm > . Acesso em: 05 março 2014.

BRASIL. Presidente (1995-2003). Discursos selecionados do Presidente Fernando Henrique Cardoso. Brasília: Fundação Alexandre de Gusmão, 2009b. 92p.

BRASIL. Presidente (2003 - :Lula). Discursos selecionados do Presidente Luiz Inácio Lula da Silva. Brasília: Fundação Alexandre de Gusmão, 2008.

BRASIL. O Brasil nas Nações Unidas: 1946-2006: Luiz Felipe de Seixas Corrêa, organizador/ Brasília: Fundação Alexandre de Gusmão, 2007, 768p.

CEPALUNI, Gabriel. Regimes internacionais e o contencioso das patentes para medicamentos: estratégias para países em desenvolvimento. Contexto Internacional, v. 27, n. 1. Rio de Janeiro, 2005. Disponível em: < http://www.scielo.br/scielo.php?pid= S0102-85292005000100002\&script = sci_abstract\&tlng = pt > . Acesso em: 12 abril 2014 . CERVO, Amado. A política exterior: de Cardoso a Lula. Revista Brasileira de Política Internacional, v. 46, n. 1, 2003. Disponível em: < http://www.scielo.br/scielo.php? script = sci_arttext\&pid = S0034-73292003000100001 > . Acesso em: 02 fev. 2014 . 
CERVO, Amado; BUENO, Clodoaldo. História da Política Exterior do Brasil. Brasília: Editora UnB, 2011.

FIDLER, David. Health in foreign policy: An analytical overview. Canadian Foreign Policy Journal, v.15, n.3, 2009. Disponível em: < http://graduateinstitute.ch/files/live/sites/ iheid/files/sites/globalhealth/shared/Training/SEEHN_course/fidler \%20health \% 20 in \%20foreign \% 20policy \% 202011.pdf > . Acesso em: 01 dez. 2013.

LIMA, Maria Regina. Aspiração Internacional e Política Externa. Revista Brasileira de Comércio Exterior, n.82, ano XIX, 2005.Disponível em: < file://C:/Users/tmarques/ Downloads/LIMA_aspira \% C3\% A7 \% C3 \% A3o_internacional_pol\%C3\% ADtica_ externa.pdf > . Acesso em: 02 nov. 2013.

PAROLA, Alexandre. A ordem injusta. Brasília: FUNAG, 2007.

PECEQUILO, Cristina. A política externa do Brasil no século XXI: os eixos combinados de cooperação horizontal e vertical. Revista Brasileira de Política Internacional, v. 51, n. 2, 2008. Disponível em: < http://www.scielo.br/scielo.php?pid=S0034$73292008000200009 \&$ script $=$ sci_abstract\&tlng $=$ pt $>$. Acesso em: 20 jan. 2014.

PINHEIRO, Letícia. Política Externa Brasileira (1889-2002). Rio de Janeiro: Jorge Zahar Editora, 2004.

PIRES-ALVES, Fernando; PAIVA, Carlos; SANTANA, José. A internacionalização da saúde: elementos contextuais e marcos institucionais da cooperação brasileira. Rev. Panam Salud Publica, v. 32, n. 6, p. 444-50, 2012. Disponível em: < http://pesquisa.bvs. br/brasil/resource/pt/lil-662924 > . Acesso em: 03 fev. 2014.

PONTE, Carlos. Pesquisa versus Produção em Manguinhos: constrangimentos e perspectivas de desenvolvimento tecnológico em uma instituição pública. 2012. Tese (Doutorado em Políticas Públicas, Estratégias e Desenvolvimento) - Universidade Federal do Rio de Janeiro, Rio de Janeiro.

PUNTIGLIANO, Andrés. Tornando-se Global: Um estudo organizacional da política externa brasileira. Revista Brasileira de Política Internacional, v.51, n.1, p. 28-52, 2008. Disponível em: < http://www.scielo.br/scielo.php?pid = S0034-73292008000100002\&script = sci_ abstract\&tlng $=$ pt $>$. Acesso em: 03 jan. 2014.

RUBARTH, Ernesto. A Diplomacia Brasileira e os Temas Sociais: o caso da Saúde. Brasília: Instituto Rio Branco, Fundação Alexandre Gusmão, Centro de Estudos Estratégicos, 1999.

SARAIVA, Miriam. As estratégias de cooperação Sul-Sul nos marcos da política externa brasileira de 1993 a 2007. Revista Brasileira de Política Internacional, v. 50, n. 2, 2007. Disponível em: < http://www.scielo.br/scielo.php?pid = S0034-73292007000200004\& script $=$ sci_abstract\&tlng $=$ pt $>$. Acesso em: 01 março 2014 .

SÁ-SILVA, Jackson; ALMEIDA, Cristóvão; GUINDANI, Joel. Pesquisa documental: pistas teóricas e metodológicas. Revista Brasileira de História e Ciências Sociais, n. 1, p. 1-14, 2009. Disponível em: < https://www.rbhcs.com/rbhcs/article/view/6 > . Acesso em: 02 jan. 2014. 
SOUZA, Amaury. Agenda Internacional do Brasil: um Estudo sobre a Comunidade Brasileira de Política Externa. Rio de Janeiro: CEBRI, 2002.

SOUZA, André. Saúde pública, patentes e atores não estatais: a política externa do Brasil ante a epidemia de AIDS. In: Letícia Pinheiro e Carlos Milani (Org.), Política Externa Brasileira: A política das práticas e as práticas da política. Rio de Janeiro: FGV, 2011. TOSCANO, Marcela. A Formação do Regime Internacional de Controle do Tabaco: 1999 a 2005. 2006. Dissertação (Mestrado em Relações Internacionais) — Universidade de Brasília, Brasília.

VAZ, Alcides Costa. Brazilian foreign policy under Lula: Change or continuity? Friedrich Ebert Foundation. Briefing Paper, 2004.

VIGEVANI, Tullo; CEPALUNI, Gabriel. A Política Externa de Lula da Silva: a Estratégia da Autonomia pela Diversificação. Contexto Internacional, v. 29, n. 2, 2007. Disponível em: < http://www.scielo.br/scielo.php?script = sci_arttext\&pid = S0102-85292007000200002 > . Acesso em: 05 set. 2013.

VIGEVANI, Tullo; OLIVEIRA, Marcelo. A política externa brasileira na era FHC: um exercício de autonomia pela integração. Tempo Social, v. 15, n. 2, 2003. Disponível em: < https://periodicos.ufsc.br/index.php/interthesis/article/view/708 > . Acesso em: 05 nov. 2013. 


\title{
A condição semiperiférica do Brasil na economia-mundo capitalista: novas evidências ${ }^{1}$
}

\author{
The semiperipheral condition of Brazil in \\ the capitalist World-economy: further evidence
}

DOI: $10.21530 /$ ci.v12n3.2017.711

Helton Ricardo Ouriques²

Pedro Antonio Vieira ${ }^{3}$

\section{Resumo}

Sob vários indicadores econômicos e sociais, o Brasil ocupa uma posição considerada "intermediária” na economia-mundo capitalista. Dentro do marco teórico da análise dos sistemas-mundo, que fundamenta nossa investigação, o Brasil pode ser considerado um Estado semiperiférico. Essa conceituação foi criada originalmente por Immanuel Wallerstein nos anos de 1970, quando lançou sua principal obra (O moderno sistema-mundial). Posteriormente, o conceito de semiperiferia foi refinado e fundamentado em termos empíricos por Giovanni Arrighi e alguns colaboradores de pesquisa na segunda metade dos anos de 1980. O Brasil, nesses estudos, aparece em alguns períodos como periferia, em outros como semiperiferia. Do nosso ponto de vista, e com base em dados estatísticos e também na interpretação da conjuntura econômica, política e social das últimas duas décadas, é possível afirmar que o Brasil se tornou um importante membro da semiperiferia, embora essa posição possa estar ameaçada pela persistência de problemas estruturais que dificultam acompanhar as mudanças em ciência, tecnologia e inovação, em curso desde a década de 1970.

Palavras-chave: Brasil, semiperiferia, educação, tecnologia.

\begin{abstract}
Under various economic and social indicators, Brazil occupies a position that, in the capitalist world economy, is considered intermediate. For the Political Economy of the World-Systems, which is the framework of our investigation, Brazil can be considered a Semiperipheral

1 Os autores deixam registrado o agradecimento aos pareceristas e ao corpo editorial revisor da Carta Internacional, pelos comentários, críticas e sugestões que foram muito úteis para a melhoria da versão final deste artigo.

2 Departamento de Economia e Relações Internacionais e Programa de Pós-Graduação em Relações Internacionais da Universidade Federal de Santa Catarina (UFSC), em Florianópolis/SC, Brasil. E-mail: helton.ricardo@ufsc. br Membro do GPEPSM (Grupo de Pesquisas em Economia Política dos Sistemas-Mundo)

3 Programa de Pós-Graduação em Relações Internacionais da Universidade Federal de Santa Catarina (UFSC), em Florianópolis/SC, Brasil. E-mail: pavieira60@gmail.com. Coordenador do GPEPSM (Grupo de Pesquisas em Economia Política dos Sistemas-Mundo).

Artigo submetido em 18/09/2017 e aprovado em 19/12/2017.
\end{abstract}


State. The concept of Semiperiphery was first proposed by Immanuel Wallerstein in the 1970s, when he published the first volume of his opus magnus, The Modern World-System. In the second half of the 1980s, the concept was refined and explored in empirical studies by Giovanni Arrighi and others. In these studies, Brazil appears in some periods as periphery, in others as semiperiphery. Based on statistical data and on the interpretation of the economic, political and social conjuncture of the last two decades, we argue in this paperthat Brazil has become an important member of the semiperiphery, although this position has been threatened by the persistence of structural problems that make it difficult to keep up with the changes in Science, Technology, and Innovation that have been under way since the 1970s.

Keywords: Brazil, semiperiphery, education, technology.

\section{Introdução}

Motivada pelas angústias e dúvidas que os mais de dez anos de crise econômica lançavam sobre o futuro do país, no início da década de 1990, Lídia Goldstein questionou a suposta autonomia que muitos consideravam que o Brasil havia conquistado no período 1930-80 e que levava a considerar "estável nossa inserção internacional e [que] dependia de nós a escolha de como melhor usufruí-la." (Goldstein, 1994, p. 19). Retomando o tema da dependência, a autora levanta perguntas que merecem ser reproduzidas:

O que é centro e o que é periferia? Qual a relação do centro com a periferia? Qual o nível de endogeneidade possível no desenvolvimento capitalista periférico? Existe algum? Mudou o mundo ou nossa compreensão dele é que está falha? (GOLDSTEIN, 1994, p. 50)

Desde o ano de publicação do livro, o Brasil só veio conhecer um período de prosperidade e de otimismo no governo Lula (2003-2010), quando o país parecia estar se movendo para cima na hierarquia do poder e da riqueza mundiais. Essa prosperidade e otimismo cessaram em 2015, quando se instala uma brutal recessão e uma crise política igualmente alarmante. Neste contexto de dúvidas, frustração e desesperança, as perguntas levantadas por Goldenstein em 1994 continuam válidas, mas precisam ser formuladas dentro de um marco conceitual que evite a falha que a mesma autora suspeitava existir nas tentativas de compreensão do desenvolvimento capitalista brasileiro posterior a 1930.

Nossa proposta de marco conceitual adequado para reformular as indagações de Goldenstein é a economia política dos sistemas-mundo (EPSM), segundo 
a qual as posições que os países ocupam no sistema mundial é mutuamente determinada e, portanto, não pode ser alterada por iniciativa unilateral de nenhum deles. Ademais, essa mútua determinação vem se processando desde o começo desse sistema no século XVI, de modo a configurar uma hierarquia que pode ser segmentada em três blocos, em formato de pirâmide. No topo, um pequeno grupo de países que concentram grande poder e riqueza, o centro. Logo abaixo, um número maior de países de riqueza e poder medianos - a semiperiferia - e na base um grande número de países débeis econômica e politicamente, os quais conformam a periferia. Essa hierarquia é estável, como será detalhado mais adiante, e tem permanecido ao longo desses 500 anos de existência do sistema-mundo capitalista, embora alguns países tenham se movido para cima ou para baixo. Um desses países foi o Brasil, que no período 1930-1980 passou da periferia à semiperiferia, conforme será mais bem argumentado na próxima seção.

Contudo, assim como acontece com empresas e trabalhadores, a posição de um país não está garantida, pois o sistema capitalista está sempre em movimento e de tempos em tempos passa por transformações mais profundas - as chamadas revoluções tecnológicas ou as transições hegemônicas de Arrighi (1996) — que tendem a ameaçar as posições conquistadas. Por isso, do mesmo modo que empresas e trabalhadores precisam se ajustar às transformações, também os países são obrigados a atualizar seus sistemas de produção e suas instituições para poder acompanhar ou, se possível, liderar as mudanças sistêmicas. Essa última expressão merece atenção. Na perspectiva da EPSM é o sistema como um todo que se move, que se transforma, que se desenvolve. Estados, empresas, trabalhadores e outros agentes tomam medidas, mas não controlam seus resultados e consequências, as quais decorrem do funcionamento do sistema em cada momento.

Os meios (econômicos, políticos, militares e científico-tecnológicos) acumulados por cada Estado para responder, provocar mudanças ou ainda tirar vantagens da economia-mundo e assim manter ou melhorar sua posição futura estão relacionados ou dependem de sua posição atual na hierarquia acima referida ${ }^{4}$. Ademais, um país ou região pode ter desenvolvido capacidade para aproveitar determinada conjuntura da economia-mundo e logrado ascender na hierarquia da renda per capita, mas não para prosseguir nessa ascensão ou mesmo para manter a posição conquistada.

4 A essa altura, merece ser mencionada a importância da existência de forças políticas mais ou menos alinhadas com a conjuntura da economia-mundo e, por isso, mais capazes de tirar proveito dessa conjuntura. 
Seria esse o caso do Brasil, que foi capaz de aproveitar as conjunturas político-econômico-financeiras e tecnológicas da fase de expansão material do ciclo sistêmico de acumulação norte-americano (1930-75/80), mas parece não ter conseguido acompanhar as mudanças ocorridas na economia-mundo do final dos anos 1970 para cá, o que pode ameaçar inclusive sua posição semiperiférica?

Neste artigo, pretendemos oferecer argumentos e evidências que apontam para uma resposta positiva a essa pergunta. Merece ser notado que, ao constatar a existência dos três blocos de países e os casos de mobilidade intrablocos, Arrighi (1997) não chegou a estudar o que tornou possível tal mobilidade. Nesse sentido, ao estudarmos o caso do Brasil, estaremos contribuindo para preencher tal lacuna da literatura. Para tanto, na primeira seção faremos uma breve recuperação do conceito de semiperiferia, para comprovar que ele se aplica ao Brasil. Na segunda seção, mostraremos algumas evidências da posição intermediária do Brasil na economia-mundo capitalista, posição que está sob ameaças, pois há fortes indícios de que esse país não está acompanhando as mudanças científico-tecnológicas em curso desde o final dos anos de 1970.

\section{O conceito de semiperiferia: breve recapitulação e o caso brasileiro}

Embora importantíssimo para a economia política dos sistemas-mundo, com algumas exceções (KORZENIEWICZ, MORAN, 1997; PEACOCK et al, 1988; SHIE, WENG, 2011; PEINADO, 2014; TERLOUW, 1993; LIMA, 2007a e 2007b), o conceito de semiperiferia é pouco utilizado em estudos concretos e também pouco examinado teoricamente. O conceito de semiperiferia foi criado por Immanuel Wallerstein em 1974, no contexto de seu estudo abrangente sobre o moderno sistema mundial. Para ele, algumas regiões teriam um papel especial, que as caracterizaria como regiões semiperiféricas, e tal posição não seria exclusivamente econômica ou política, mas holística. A longa citação que apresentamos na sequência resume a percepção inicial do autor a respeito do assunto:

Existem também áreas semiperiféricas que se situam entre o centro e a periferia em uma série de dimensões, tais como a complexidade das atividades econômicas, a força do aparelho estatal, a integridade cultural, etc. Algumas dessas áreas eram áreas centrais em versões anteriores de uma certa economia-mundo. Outras eram áreas periféricas, promovidas mais tarde, por assim dizer, como resultado da 
mudança geopolítica de uma economia-mundo em expansão. A semiperiferia, no entanto, não é um artifício de pontos de corte estatísticos, nem é uma categoria residual. A semiperiferia é um elemento estrutural necessário em uma economiamundo. Essas áreas desempenham um papel paralelo ao representado, mutatis mutandis, pelos grupos mercantis intermediários em um império. São pontos de coleta de qualificações vitais, frequentemente politicamente impopulares. Essas áreas intermediárias (como os grupos intermediários em um império) desviam parcialmente as pressões que de outra maneira os grupos localizados nas áreas periféricas poderiam dirigir contra os estados centrais e os grupos que operam dentro deles e através de seus aparatos estatais. Por outro lado, os interesses situados principalmente na semiperiferia estão fora da arena política dos estados centrais e tem dificuldade em alcançar seus fins através de coalizões políticas que poderiam estar abertas para eles se estivessem na mesma arena política. (WALLERSTEIN 2011, 492-3) 5

É preciso recordar que o pano de fundo da análise de Wallerstein era a constatação de que tanto a teoria da modernização quanto as teorias da dependência 6 não davam conta de explicar um fenômeno que já se manifestava nos anos de 1970, a saber: a existência de Estados que estavam em posições intermediárias na economia mundial. Como se percebe, Wallerstein argumenta que a semiperiferia não era uma categoria estatisticamente artificial ou mesmo um resíduo transitório. O autor insistiu no caráter estrutural da situação semiperiférica.

5 “Existen también áreas semiperiféricas que están entre el centro y la periferia en una serie de dimensiones, tales como la complejidad de las actividades económicas, la fuerza del aparato de Estado, la integridad cultural, etc. Algunas de estas áreas eran áreas centrales en versiones anteriores de una cierta economía-mundo. Otras eran áreas periféricas, promocionadas más adelante, por así decirlo, como resultado de la geopolítica cambiante de una economía-mundo en expansión. La semiperiferia, no obstante, no es un artificio de puntos de corte estadísticos, ni tampoco una categoría residual. La semiperiferia es un elemento estructural necesario en una economíamundo. Estas áreas juegan un papel paralelo al representado, mutatis mutandis, por los grupos comerciantes intermedios en un imperio. Son puntos de recopilación de cualificaciones vitales, a menudo politicamente impopulares. Estas áreas intermedias (como los grupos intermedios en un imperio) desvián parcialmente las presiones políticas que los grupos localizados primariamente en las áreas periféricas podrían en otro caso dirigir contra los Estados del centro y los grupos que operan en el seno y a través de sus aparatos de Estado. Por otra parte, los intereses localizados primariamente en la semiperiferia se hallan en el exterior de la arena política de los Estados del centro, y encuentran difícil perseguir sus fines a través de coaliciones políticas que podrían estar abiertas para ellos si estuvieran en la misma arena política. (WALLERSTEIN 2011, 492-3)

6 As deficiências de ambas as teorias na análise da semiperiferia foram apontadas por Immanuel Wallerstein nos capítulos 4 e 5 do livro The Capitalist World-Economy, e por Giovanni Arrighi, nos capítulos 2 e 3 do livro A Ilusão do Desenvolvimento. 
Do ponto de vista econômico, esse caráter estrutural foi evidenciado por Giovanni Arrighi nos anos de $1980^{7}$. Usando o Produto Nacional Bruto ${ }^{8}$ per capita (PNB per capita), o autor percebeu a existência de uma divisão tripartite entre os Estados nacionais ao longo do período 1938-1985. É importante observar que nessa estrutura tripartite, a posição é exclusivamente "em relação à divisão mundial do trabalho e nunca [no] sistema inter-estados” (ARRIGHI,DRANGEL, 1997, p. 144). Com base nos dados, esses autores concluem que

95\% dos Estados para os quais havia dados disponíveis (e 94\% da população total) estavam, em 1975/83, nas ou no interior das fronteiras da zona na qual se encontravam em 1938/50. Considerando-se o período como um todo, a mobilidade para cima ou para baixo no sistema foi verdadeiramente excepcional. (idem, 173, grifos nossos)

Mesmo destacando a excepcionalidade da mobilidade, os autores afirmam ser possível um Estado periférico ou semiperiférico alcançar uma posição superior (ou seja, passar da periferia para a semiperiferia e da semiperiferia para o núcleo orgânico). Contudo, dado que a desigualdade e a polarização marcam a história da economia-mundo capitalista, o movimento de ascensão posicional ${ }^{9}$ de uma dada jurisdição impede outras de fazerem o mesmo.

Esses autores assinalam ainda que determinados Estados puderam e podem atuar sobre a estrutura tripartite da economia mundial, melhorando suas respectivas posições, como apontado acima. E de que forma podem fazer isso? Os Estados semiperiféricos individualmente,

buscando uma combinação particularmente inovadora de políticas econômicas e/ou abençoadas por uma conjuntura econômica mundial que lhes dá uma forte vantagem competitiva, possam [podem] melhorar sua combinação de atividades de núcleo orgânico e de periferia, até que se tornem Estados do núcleo orgânico. (idem, 159)

7 Através dos artigos A ascensão do Leste Asiático: um milagre ou muitos? (escrito em coautoria com Jessica Drangel) e A ascensão do Leste Asiático: aspectos regionais e sistêmicos mundiais. Ambos foram publicados no Brasil em 1997, reunidos no livro A ilusão do desenvolvimento. Quando for citado o primeiro artigo, usaremos Arrighi, Drangel (1997).

8 O PNB é uma medida de comando sobre fontes econômicas mundiais, pois mensura o controle que cidadãos de uma dada jurisdição possuem sobre recursos em sua própria jurisdição e também no exterior. Arrighi, Drangel consideraram que se tratava de um conceito operacional, capaz de mensurar, ao longo do tempo, as capacidades de comando dos Estados sobre as fontes de riqueza globais.

9 É preciso notar que não se trata apenas de desenvolvimento, no sentido de aumentar o PIB per capita, mas sim de alcançar os níveis do PIB per capita dos países do centro do sistema mundial. 
De acordo com Arrighi, dado que a mobilidade no sistema não está descartada (embora seja considera excepcional), é possível que um determinado Estado tenha sucesso na luta contra os processos de exclusão e exploração ${ }^{10}$. A luta contra a exclusão "é uma luta por um nicho comparativamente seguro na divisão mundial do trabalho” (ARRIGHI, 1997, p. 218) e implica

1) uma maior especialização das atividades nas quais o Estado semiperiférico tem ou pode obter algum tipo de vantagem competitiva, 2) um envolvimento ativo nas relações de troca desigual, nas quais o Estado semiperiférico fornece mercadorias que incorporam mão-de-obra mal remunerada para os Estados do núcleo orgânico em troca de mercadorias que incorporam mão-de-obra bem remunerada e 3) uma exclusão mais completa dos Estados periféricos das atividades nas quais o Estado semiperiférico busca maior especialização (idem, ibidem).

O Brasil, em especial depois da década de 1940, com a industrialização via substituição de importações, empreendeu a luta contra a exclusão, promovendo a industrialização via empresas nacionais - privadas e estatais - e empresas multinacionais, essas últimas atraídas pela força de trabalho barata e pelo mercado interno protegido. Subsidiariamente também foram fortalecidas as históricas condições para a exportação de produtos primários, como minério de ferro e café.

Se, por um lado, a decisiva participação de empresas e tecnologias estrangeiras possibilitou implantar a industrialização em uma economia e sociedade secularmente agrária, por outro impediu criar capacidades científico-técnicas próprias, o que por sua vez evitou mudanças profundas nas instituições e estruturas sociais e estatais. No decorrer dessa industrialização orientada pelo Estado, foram desenvolvidas capacidades educacionais, científicas e tecnológicas suficientes apenas para copiar e operar máquinas e processos importados do centro pelas empresas estrangeiras aqui instaladas, ou adquiridos pelas empresas nacionais, fossem elas estatais - como a Companhia Siderúrgica Nacional - ou privadas. O nível de capacidades científico-tecnológicas exigido para operar a tecnologia importada não impôs a criação de contingente massivo de força de trabalho qualificada, de

10 As lutas contra a exploração visam criar divisões do trabalho "tão autônomas quanto possível da divisão axial do trabalho na economia capitalista mundial” (idem, p. 219), o que implica: “1) o incumbir-se, por parte do Estado semiperiférico, de uma ampla gama de atividades, independente de vantagem comparativa, 2) a autoexclusão do Estado semiperiférico de relações de troca desigual com os Estados do núcleo orgânico e 3) um envolvimento ativo em relações de troca desigual, nas quais o Estado semiperiférico fornece mercadorias que incorporam mão-de-obra bem remunerada a Estados periféricos em troca de mercadorias que incorporam mãode-obra mal remunerada” (ARRIGHI, 1997, p. 217). 
técnicos, de engenheiros e também empresários capazes de tornar a inovação parte constitutiva do funcionamento das empresas e das instituições de ensino e dos órgãos governamentais.

Em todo caso, mesmo com avanços e recuos, através da industrialização substitutiva de importações, entre as décadas de 1930 e 1970 o país ascendeu da periferia para a semiperiferia (AREND, 2013) ${ }^{11}$. Contudo, isso ocorreu no contexto da fraqueza do Estado brasileiro, em comparação aos Estados do Leste Asiático, como mencionado por Fiori (1994). De fato, nesses países o Estado efetivamente conduziu o processo de industrialização. No Japão, Coréia do Sul, Taiwan e China, o Estado foi forte no sentido de formular diretrizes políticas independentemente de grupos particulares e de modificar a estrutura da sociedade (CUMINGS, 1984). Contudo, em marcante divergência com a experiência brasileira, além da força do Estado, no Leste Asiático a industrialização da primeira metade do século XX se baseou em empresas nacionais, que foram estimuladas a desenvolver tecnologias próprias, a educação primária foi universalizada e o ensino técnico desenvolvido. Além disso, no caso específico da Coreia do Sul, uma reforma agrária eliminou as forças reacionárias baseadas na posse da terra.

O fato é que há um contraste entre os países da industrialização tardia, como bem identificou Alice Amsden (2009, p. 46):

China, Índia, Coreia e Taiwan começaram a investir pesado em habilidades nacionais próprias, o que as ajudou a sustentar a propriedade nacional de empresas nas indústrias de média tecnologia e a invadir setores de alta tecnologia com base em "líderes nacionais". Em contraste, Argentina e México e, em menor medida, Brasil e Turquia aumentaram sua dependência do knowhow estrangeiro para o crescimento futuro. Nesses países, o investimento estrangeiro predominou, mas os gastos locais em ciência e tecnologia por parte de investidores estrangeiros foram praticamente nulos.

As características da industrialização brasileira - Estado fraco nos planos político, fiscal e financeiro; dependência de tecnologias importadas; ausência de empresas nacionais capazes de gerar soluções tecnológicas próprias - revelaram toda a sua força na década de 1980 quando, ao mesmo tempo que a industrialização

11 “Ao enveredar para a estratégia desenvolvimentista internacionalista desde meados da década de 1950, consolidou seu status semiperiférico no sistema interestatal, a partir da internacionalização de seu parque produtivo nacional via ingresso de empresas multinacionais (periferização de atividades industriais)” (Arend 2013, p. 165). 
substitutiva de importações tinha chegado a seu auge, reduziram-se os empréstimos externos e, na mesma proporção, a capacidade de financiamento do Estado brasileiro, que se viu impotente para fomentar a entrada na terceira revolução industrial de um parque que não tinha incorporado a inovação tecnológica ao seu modo normal de funcionamento:

É justamente no período posterior a 1970 que a inovação tecnológica passa a depender ainda mais da ciência e que se dá a interação entre as indústrias de telecomunicações, computadores e periféricos, nanotecnologia, engenharia genética e biotecnologia. As duas tendências se combinam para dificultar a diminuição do gap científico-tecnológico estruturalmente existente entre o centro e a semiperiferia/periferia da economia-mundo, pois os recursos financeiros, humanos e técnicos exigidos para gerar inovações estão muito além das capacidades acumuladas por Estados e capitais periféricos e semiperiféricos. (VIEIRA, FERREIRA, 2013, p. 268)

Nesse texto, no qual analisam a posição do Brasil na atual conjuntura científico-tecnológica da economia-mundo, os autores argumentam que, ao se basear na abundância de recursos naturais e humanos, a produção de bens primários para exportação gerou agentes econômicos e instituições refratários ao desenvolvimento da ciência, da tecnologia e da inovação.

A divergência de trajetória em relação ao Leste Asiático, nesse sentido, é marcante, pois aqueles países, entre os anos 1950 e 1970, prepararam as condições para acompanhar e mesmo liderar certos setores (como o automobilístico e o eletroeletrônico) e assim avançar para o centro, como foi o caso do Japão e da Coreia do Sul12.

No Brasil, país com mais de 200 milhões de habitantes e com ilhas de riqueza e prosperidade, a debilidade estrutural para o desenvolvimento socialmente significativo e impactante de inovação não impede a existência de casos de sucesso na ciência e na tecnologia. Entre outros casos exitosos, podem ser mencionados a Petrobras (empresa que, entre outras inovações, desenvolveu tecnologias para exploração de petróleo em águas profundas), o programa Proálcool³ ${ }^{13}$ a Embraer (Empresa Brasileira de Aeronáutica S.A.) e os aprimoramentos tecnológicos no

12 Para detalhes sobre a ascensão do Leste Asiático, ver Arrighi (1997) e Amsden (2009).

13 Pró-Álcool era o Programa Nacional do Álcool, um projeto do governo brasileiro que, no final dos anos de 1970 , desenvolveu tecnologias de utilização do álcool como combustível para veículos. 
agronegócio, em parte devidos às pesquisas realizadas nas últimas décadas pela Embrapa (Empresa Brasileira de Pesquisa Agropecuária). Deve ser observado que, em dois desses casos, foi acrescentada uma vantagem comparativa artificial - a inovação tecnológica - a uma vantagem comparativa natural, a abundância de recursos naturais. Já a Embraer, criada em 1970 - portanto, durante o regime militar - foi "concebida como uma estatal e como uma montadora final, que se dedicaria exclusivamente à montagem de aviões através da materializac , ão de um projeto aeronáutico endogenamente concebido" (BERNARDES, 2000, p. 7). Esse caso de sucesso na produção de um produto que incorpora tecnologia de ponta, com alta sensibilidade geopolítica, tem três aspectos que merecem ser destacados: 1) foi uma iniciativa do Estado; 2) não teve que enfrentar a resistência de empresas multinacionais instaladas no Brasil; e 3) destinava-se ao mercado mundial.

Sem embargo, por não ter avançado na criação das condições políticas, econômicas e sociais que permitiriam replicar o caso da Embraer para outros setores e produtos, o país parece estar estacionado na posição semiperiférica e ainda está longe, muito longe, dos padrões de riqueza do centro. A explicação teórica para tal situação relaciona-se com o fato de que os Estados semiperiféricos

podem, individualmente, conseguir e conseguem cruzar o golfo que separa a riqueza modesta da semiperiferia da riqueza oligárquica do núcleo orgânico, como ocorreu com o Japão recentemente e com alguns outros antes do Japão. (ARRIGHI, 1997, p. 219)

Contudo, o problema fundamental permanece o mesmo, pois, enquanto grupo, não é possível que todos os Estados semiperiféricos passem para a condição de núcleo orgânico, porque isso é incompatível com as tendências polarizadoras da economia mundial capitalista.

Como evidenciaremos na próxima seção, o Brasil pode ser enquadrado na situação semiperiférica, inclusive com base em outros indicadores, que não o PNB per capita. É importante frisar que a zona semiperiférica, de acordo com estudos posteriores (ARRIGHI et al, 1996 LIMA, 2007a) ${ }^{14}$, permanece estável ao

14 Esses dois estudos empíricos cobrem períodos de tempo posteriores aos analisados por Giovanni Arrighi nos dois artigos aqui citados (ou seja, o período 1938-1983). Em 1996, Arrighi et al., no texto Modeling zones of the World-Economy: a Polymonial Regression Analysis (1964-1994), apresentaram novos dados, que continuaram confirmando a existência de três zonas estruturais na economia mundial (abarcando um período de mais 10 anos posteriores à data final do estudo original de Arrighi e Drangel). E, mais recentemente, Lima (2007a), utilizando outra metodologia (usando o PIB per capita como base e não o PNB per capita), também percebeu a persistência da mesma situação para o período 1950-2003. 
longo do tempo, configurando-se, portanto, como um elemento constituinte e mesmo como uma estrutura da economia-mundo capitalista. Serão mostradas outras evidências para sustentar a hipótese de que o Brasil é de fato um membro importante da zona semiperiférica, embora essa condição pareça estar sendo ameaçada - o Brasil continua se mostrando incapaz de superar suas históricas carências em educação, ciência, tecnologia e inovação.

\section{O Brasil como semiperiferia: evidências iniciais}

Vários indicadores permitem sustentar a tese de que o Brasil se encontra em uma posição intermediária na economia-mundo capitalista. Dotado de abundância de recursos naturais, grande contingente populacional, diversificado parque industrial e, ainda, uma enorme desigualdade social e de renda, o país apresenta características de Estado semiperiférico, pois possui em seu território uma mescla de atividades de núcleo orgânico e de periferia. Além disso, como costumeiramente divulgado pela imprensa especializada, em vários indicadores o país se encontra em posição intermediária. Como exemplo, podemos mencionar a 79a posição do país no ranking do IDH (Índice de Desenvolvimento Humano). E, no próprio campo das relações internacionais, tal status aparece, quando o Brasil é descrito como "emergente" e/ou "potência média" (SENNES, 1998). Nesta seção, pretendemos apresentar outros indicadores que parecem confirmar tal percepção da posição semiperiférica do Brasil.

No estudo original de Arrighi e Drangel (1997), citado na seção anterior, o Brasil aparece em situação oscilante ao longo do período 1938-1983, ora como membro da periferia, ora como semiperiferia. Por esse motivo, não foi considerado pelos autores um membro “orgânico" da zona semiperiférica, mas foi incluído na lista de um possível representante desse estrato. Immanuel Wallerstein, por sua vez, desde o início da criação do conceito de semiperiferia, classificou o Brasil como um Estado membro desse grupo (WALLERSTEIN, 1979). 


\section{Gráfico 1 - Evolução do PIB per capita do Brasil e países selecionados em relação aos EUA (EUA $=100)$, entre 1950 e 2014}

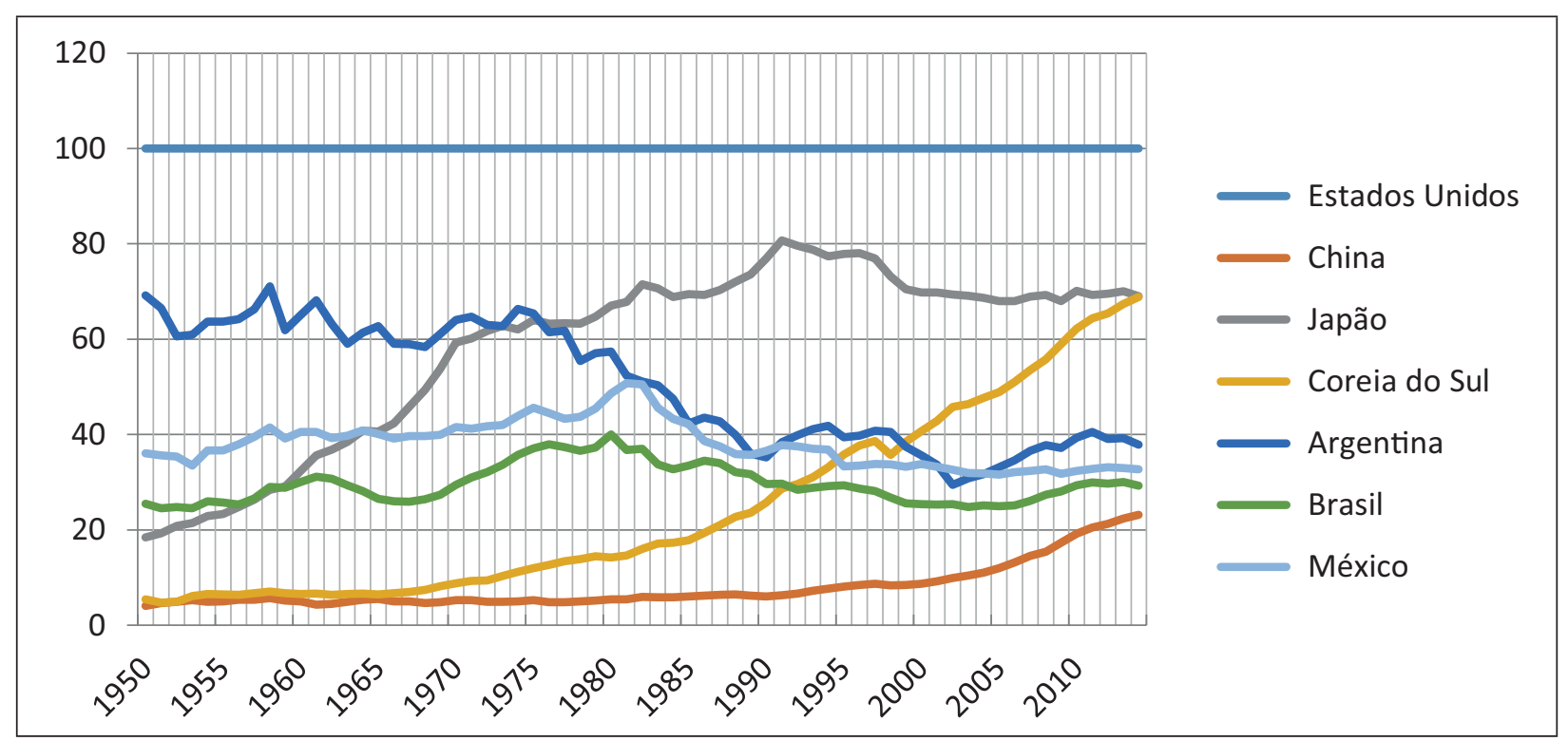

Fonte: BOLT; VAN ZOLDEN (2013), Maddison Project. Elaboração própria.

Nos termos acima apresentados, do mesmo modo que ao final dos anos de 1970, é possível ainda hoje classificar o Brasil como Estado semiperiférico, tal como argumentado por Arend (2013), citado anteriormente. Lima (2007b), com metodologia própria ${ }^{15}$, mostrou a evolução do Brasil em termos do percentual do PIB per capita dos EUA, para o período 1950-2003, e percebeu que o país se comportou como membro da zona semiperiférica ao longo desse horizonte temporal. Atualizando esses dados até o ano de 2014, portanto, cobrindo o período 1950-2014, evidencia-se a persistência do Brasil na condição semiperiférica, pois, ao longo desses 54 anos, o PIB per capital brasileiro oscilou entre $20 \%$ e $30 \%$ do PIB per capita dos EUA, conforme indicado no Gráfico 1.

Essa condição semiperiférica, entretanto, parece ser muito frágil, diante dos resultados obtidos em vários indicadores extraídos do documento The Global Competitiveness Report 2014-15, elaborado pelo World Economic Forum (Tabela 1). Mesmo sendo um retrato do período recente, esses dados ilustram o caráter intermediário da condição brasileira. No documento em questão, cada um dos indicadores é detalhado em vários quesitos. Assim, no indicador "Saúde e Educação Primária”, a posição do Brasil no ranking (para um total de 144 países) nos itens

15 Em seu estudo, Lima (2007a) comparou o PIB per capita dos países com o PIB per capita dos EUA, em paridade do poder de compra (estimada por Angus Maddison). A semiperiferia, na média do período 1950-2003, teve um PIB per capita oscilando entre $20 \%$ e $30 \%$ do PIB per capita dos EUA. Para detalhes sobre a metodologia, ver o trabalho mencionado. 
"expectativa de vida", "mortalidade infantil" e "qualidade da educação primária" é, respectivamente, a 78a a $65^{\mathrm{a}}$ e a $126^{\mathrm{a}}$. No indicador "Inovação”, a posição do Brasil nos itens "capacidade para inovação" e "disponibilidade de cientistas e engenheiros” é, respectivamente, a 44a e a 114a (WORLD ECONOMIC FORUM, 2015, p. 135). Além disso, o Coeficiente de Gini do país foi de 51,5 no período 2010-2015, evidenciando que o Brasil possui uma das piores distribuições de renda no mundo, apenas superado por outros nove países (HUMAN DEVELOPMENT REPORT, 2016) ${ }^{16}$.

\section{Tabela 1 - Índice de Competitividade Global do Brasil (2014-2015) entre 144 países analisados}

\begin{tabular}{lcc}
\hline \multicolumn{1}{c}{ Indicador } & Ranking & Score (1-7) \\
\hline Índice de Competitividade Global 2014-2015 & 57 & 4,3 \\
Índice de Competitividade Global 2013-2014 (de 148) & 56 & 4,3 \\
Índice de Competitividade Global 2012-2013 (de 144) & 48 & 4,4 \\
Índice de Competitividade Global 2011-2012 (de 142) & 53 & 4,3 \\
Requisitos Básicos & & \\
Instituições & 83 & 4,4 \\
Infraestrutura & 94 & 3,5 \\
Ambiente Macroeconômico & 76 & 4 \\
Saúde e Educação Primária & 85 & 4,5 \\
& 77 & 5,7 \\
Indicadores de Eficiência & & 4,5 \\
Educação Qualificada e Treinamento & 42 & 4,9 \\
Eficiência no Mercado de Bens & 41 & 3,8 \\
Eficiência no Mercado de Trabalho & 123 & 3,8 \\
Desenvolvimento do Mercado Financeiro & 103 & 4,3 \\
Agilidade Tecnológica & 53 & 4,2 \\
Tamanho do Mercado & 58 & 5,7 \\
Fatores de Inovação e Sofisticação & 9 & 3,3 \\
Sofisticação Empresarial & & 4,3 \\
Inovação & 56 & 37 \\
\hline
\end{tabular}

Fonte: World Economic Forum. The Global Competitiviness Report 2014-2015. Elaboração dos autores.

16 O Coeficiente de Gini é um indicador de desigualdade, variando de 0 a 100. Quanto mais próximo de 100, mais desigual é a distribuição de renda. Os países com Coeficiente de Gini mais elevado do que o do Brasil no período 2010-2015 eram África do Sul $(63,4)$, Botsuana $(60,5)$, Colômbia $(53,5)$, Haiti $(60,8)$, Lesoto $(54,2)$, Namíbia $(61,0)$, Paraguai $(51,7)$, República Centro Africana $(56,2)$ e Zâmbia $(55,6)$. A título de comparação, o Coeficiente de Gini da Noruega, primeiro colocado no ranking de desenvolvimento humano, foi de 25,9. (HUMAN DEVELOPMENT REPORT, 2016.) 
Com relação ao Índice de Desenvolvimento Humano (IDH) e alguns de seus componentes, a Tabela 2 evidencia um retrato da situação brasileira em 2015. Na 79ª posição no indicador do IDH, o Brasil está abaixo dos países selecionados da América Latina na expectativa de vida ao nascer, nos anos de escolaridade e no PNB per capita. Embora também seja apenas um retrato de período mais recente, evidencia a defasagem do Brasil em relação ao centro e mesmo em relação a outros países da América Latina.

\section{Tabela 2 - Índice de Desenvolvimento Humano (IDH) e alguns de seus componentes (2015)}

\begin{tabular}{lcccc}
\hline \multicolumn{1}{c}{ País } & $\begin{array}{c}\text { Ranking } \\
\text { IDH }\end{array}$ & $\begin{array}{c}\text { Expectativa de vida ao } \\
\text { nascer (em anos) }\end{array}$ & $\begin{array}{c}\text { Anos de } \\
\text { escolaridade }\end{array}$ & $\begin{array}{c}\text { PNB per capita } \\
\text { (U\$ PPP 2011) }\end{array}$ \\
\hline Noruega & 1 & 81,7 & 12,7 & 67.614 \\
Alemanha & 4 & 81,1 & 13,2 & 45.000 \\
EUA & 10 & 79,2 & 13,2 & 53.245 \\
Reino Unido & 16 & 80,8 & 13,3 & 37.931 \\
França & 21 & 82,4 & 11,6 & 38.085 \\
Japão & 17 & 83,7 & 12,5 & 37.268 \\
Coréia do Sul & 18 & 82,1 & 12,2 & 34.541 \\
Chile & 38 & 82 & 9,9 & 21.665 \\
Argentina & 45 & 76,5 & 9,9 & 20.945 \\
Uruguai & 54 & 77,4 & 8,6 & 19.148 \\
México & 77 & 77 & 8,6 & 16.383 \\
Brasil & 79 & 74,7 & 7,8 & 14.145 \\
Mundo & - & 71,6 & 8,3 & 14.447 \\
\hline
\end{tabular}

Fonte: Human Development Report, 2016. Elaborada pelos autores.

Com relação a indicadores educacionais, o estudo de Barbosa Filho \& Moura (2013), que compara países desenvolvidos e que tiveram sucesso em alcançar o desenvolvimento com países que não foram bem-sucedidos, é elucidativo a respeito da posição intermediária brasileira. Embora tenha efetivamente ocorrido uma melhoria nos indicadores nos últimos anos (como taxa de matrícula, anos médios de educação, grau de escolarização), em termos comparados o Brasil ainda está muito atrás de outros países, como mostram as Tabelas 3, 4 e 5 . 
Tabela 3 - Grau de escolarização (\%)

\begin{tabular}{lccccccc}
\hline & $\mathbf{1 9 5 0}$ & $\mathbf{1 9 6 0}$ & $\mathbf{1 9 7 0}$ & $\mathbf{1 9 8 0}$ & $\mathbf{1 9 9 0}$ & $\mathbf{2 0 0 0}$ & $\mathbf{2 0 1 0}$ \\
\hline França & 99,7 & 99,7 & 99,0 & 99,1 & 92,0 & 97,3 & 98,7 \\
Alemanha & 97,7 & 97,4 & 95,5 & 94,8 & 95,0 & 94,9 & 96,0 \\
Japão & 95,6 & 97,6 & 99,3 & 99,6 & 99,8 & 99,8 & 99,9 \\
EUA & 97,8 & 98,0 & 98,6 & 99,2 & 98,9 & 99,6 & 99,7 \\
Reino Unido & 97,2 & 97,8 & 98,0 & 97,0 & 96,8 & 96,6 & 96,7 \\
Países desenvolvidos & $\mathbf{9 7 , 6}$ & $\mathbf{9 8 , 1}$ & $\mathbf{9 8 , 1}$ & $\mathbf{9 7 , 9}$ & $\mathbf{9 6 , 5}$ & $\mathbf{9 7 , 6}$ & $\mathbf{9 8 , 2}$ \\
Hong Kong & 61,4 & $\mathbf{6 8 , 3}$ & 75,9 & 83,8 & 87,4 & 81,7 & 87,5 \\
Coreia do Sul & 72,2 & 57,4 & 75,7 & 86,9 & 88,6 & 94,1 & 96,4 \\
Cingapura & 38,9 & 50,6 & 65,7 & 70,2 & 89,8 & 90,9 & 91,8 \\
Taiwan & 58,3 & 66,5 & 76,4 & 84,3 & 90,5 & 95,1 & 97,6 \\
Países asiáticos* & $\mathbf{5 7 , 7}$ & $\mathbf{6 0 , 7}$ & $\mathbf{7 3 , 4}$ & $\mathbf{8 1 , 3}$ & $\mathbf{8 9 , 1}$ & $\mathbf{9 0 , 5}$ & $\mathbf{9 3 , 3}$ \\
Argentina & 85,9 & 89,8 & 93,0 & 95,1 & 95,2 & 96,5 & 97,6 \\
Chile & 78,9 & 82,5 & 90,3 & 93,2 & 95,4 & 95,8 & 96,8 \\
Colômbia & 59,8 & 68,3 & 76,6 & 83,2 & 88,1 & 90,4 & 95,0 \\
México & 54,6 & 59,9 & 68,2 & 72,5 & 83,4 & 89,7 & 94,0 \\
Venezuela & 50,6 & 59,0 & 66,8 & 82,0 & 81,9 & 85,5 & 88,7 \\
Países latino-americanos ${ }^{* *}$ & $\mathbf{6 6 , 0}$ & $\mathbf{7 1 , 9}$ & $\mathbf{7 9 , 0}$ & $\mathbf{8 5 , 2}$ & $\mathbf{8 8 , 8}$ & $\mathbf{9 1 , 6}$ & $\mathbf{9 4 , 4}$ \\
China & 30,2 & 41,7 & 58,1 & 72,9 & 77,8 & 89,0 & 93,5 \\
Brasil & 37,2 & 48,2 & 62,2 & 72,6 & 77,7 & 84,0 & 89,9 \\
\hline
\end{tabular}

Fonte: Barbosa Filho, Moura (2013). ( $\left.{ }^{*}\right)$ Média sem a China; $\left({ }^{* *}\right)$ Média sem o Brasil.

Tabela 4 - Anos médios de escolaridade

\begin{tabular}{lccccccc}
\hline & $\mathbf{1 9 5 0}$ & $\mathbf{1 9 6 0}$ & $\mathbf{1 9 7 0}$ & $\mathbf{1 9 8 0}$ & $\mathbf{1 9 9 0}$ & $\mathbf{2 0 0 0}$ & $\mathbf{2 0 1 0}$ \\
\hline França & 4,3 & 4,2 & 4,8 & 6,0 & 7,5 & 9,6 & 10,5 \\
Alemanha & 4,9 & 5,1 & 5,0 & 5,6 & 8,0 & 10,0 & 11,8 \\
Japão & $\mathbf{6 , 9}$ & 8,0 & 8,2 & 9,3 & 10,0 & 10,9 & 11,6 \\
EUA & 8,4 & 9,1 & 10,8 & 12,0 & 12,1 & 12,7 & 12,2 \\
Reino Unido & 5,9 & 6,3 & 7,3 & 7,7 & 8,1 & 8,8 & 9,6 \\
Países desenvolvidos & $\mathbf{6 , 1}$ & $\mathbf{6 , 6}$ & $\mathbf{7 , 2}$ & $\mathbf{8 , 1}$ & $\mathbf{9 , 2}$ & $\mathbf{1 0 , 4}$ & $\mathbf{1 1 , 1}$ \\
Hong Kong & 4,4 & 4,9 & 6,3 & 8,0 & 9,4 & 9,3 & 10,4 \\
Coreia do Sul & 4,5 & 4,3 & 6,3 & 8,3 & 9,3 & 11,1 & 11,8 \\
Cingapura & 2,7 & 3,7 & 5,2 & 5,2 & 6,6 & 8,1 & 9,1 \\
Taiwan & 4,3 & 5,0 & 6,1 & 7,6 & 8,7 & 10,1 & 11,3 \\
Países asiáticos* & $\mathbf{4 , 0}$ & $\mathbf{4 , 5}$ & $\mathbf{6 , 0}$ & 7,3 & $\mathbf{8 , 5}$ & $\mathbf{9 , 6}$ & $\mathbf{1 0 , 7}$ \\
Argentina & 4,8 & 5,7 & 6,3 & 7,3 & 8,3 & 8,7 & 9,3 \\
Chile & 4,8 & 5,2 & 6,1 & 7,0 & 8,4 & 9,1 & 10,2 \\
Colômbia & 2,3 & 3,1 & 3,9 & 4,9 & 6,0 & 6,9 & 7,7 \\
México & 2,4 & 2,8 & 3,6 & 4,9 & 6,4 & 7,6 & 9,1 \\
Venezuela & 2,2 & 3,1 & 4,0 & 5,6 & 5,1 & 5,9 & 7,0 \\
Países latino-americanos ${ }^{* *}$ & $\mathbf{3 , 3}$ & $\mathbf{4 , 0}$ & $\mathbf{4 , 8}$ & $\mathbf{5 , 9}$ & $\mathbf{6 , 8}$ & $\mathbf{7 , 6}$ & $\mathbf{8 , 7}$ \\
China & 1,5 & 2,3 & 3,4 & 4,7 & 5,6 & 7,1 & 8,2 \\
Brasil & 1,5 & 2,1 & 2,8 & 2,8 & 4,5 & 6,4 & 7,5 \\
\hline
\end{tabular}

Fonte: Barbosa Filho, Moura (2013). (*) Média sem a China; $\left({ }^{* *}\right)$ Média sem o Brasil 
Tabela 5 - Percentual da população acima de 15 anos com pelo menos o ensino secundário completo (\%)

\begin{tabular}{lccccccc}
\hline & $\mathbf{1 9 5 0}$ & $\mathbf{1 9 6 0}$ & $\mathbf{1 9 7 0}$ & $\mathbf{1 9 8 0}$ & $\mathbf{1 9 9 0}$ & $\mathbf{2 0 0 0}$ & $\mathbf{2 0 1 0}$ \\
\hline França & 3,9 & 5,1 & 7,9 & 16,9 & 33,8 & 52,1 & 62,5 \\
Alemanha & 6,5 & 9,0 & 10,0 & 15,8 & 35,9 & 52,9 & 68,8 \\
Japão & 21,9 & 32,5 & 33,2 & 44,5 & 50,7 & 60,5 & 67,0 \\
EUA & 36,5 & 45,3 & 63,0 & 78,9 & 77,8 & 78,7 & 82,3 \\
Reino Unido & 3,3 & 4,1 & 10,3 & 11,6 & 13,5 & 18,8 & 25,2 \\
Países desenvolvidos & $\mathbf{1 4 , 4}$ & $\mathbf{1 9 , 2}$ & $\mathbf{2 4 , 9}$ & $\mathbf{3 3 , 5}$ & $\mathbf{4 2 , 3}$ & $\mathbf{5 2 , 6}$ & $\mathbf{6 1 , 2}$ \\
Hong Kong & 13,2 & 14,6 & 21,4 & 31,0 & 41,6 & 44,9 & 55,4 \\
Coreia do Sul & 5,2 & 11,3 & 19,2 & 35,2 & 50,2 & 69,2 & 77,9 \\
Cingapura & 5,3 & 8,4 & 13,2 & 13,7 & 12,8 & 27,1 & 40,6 \\
Taiwan & 11,0 & 13,4 & 195 & 32,2 & 42,2 & 54,9 & 70,7 \\
Países asiáticos* & $\mathbf{8 , 7}$ & $\mathbf{1 1 , 9}$ & $\mathbf{1 8 , 3}$ & $\mathbf{2 8 , 0}$ & $\mathbf{3 6 , 7}$ & $\mathbf{4 9 , 0}$ & $\mathbf{6 1 , 2}$ \\
Argentina & 5,1 & 10,4 & 14,0 & 23,1 & 31,0 & 33,2 & 40,9 \\
Chile & 11,5 & 12,9 & 17,4 & 24,4 & 40,2 & 48,9 & 59,0 \\
Colômbia & 2,5 & 3,5 & 6,0 & 10,1 & 17,9 & 30,1 & 43,5 \\
México & 2,7 & 3,2 & 6,6 & 13,7 & 20,6 & 27,6 & 38,7 \\
Venezuela & 2,0 & 4,0 & 9,5 & 15,9 & 14,9 & 18,5 & 25,0 \\
Países latino-americanos** & $\mathbf{4 , 8}$ & $\mathbf{6 , 8}$ & $\mathbf{1 0 , 7}$ & $\mathbf{1 7 , 4}$ & $\mathbf{2 4 , 9}$ & $\mathbf{3 1 , 7}$ & $\mathbf{4 1 , 4}$ \\
China & 2,0 & 3,4 & 5,4 & 10,2 & 23,7 & 40,8 & 55,0 \\
Brasil & 3,9 & 5,5 & 6,5 & 7,9 & 11,9 & 23,6 & 33,7 \\
\hline
\end{tabular}

Fonte: Barbosa Filho, Moura (2013). Observações: $\left({ }^{*}\right)$ Média sem a China; $\left({ }^{* *}\right)$ Média sem o Brasil

Como pode ser percebido na Tabela 4, apesar da melhoria no indicador desde 1990 (pois passou de 4,5 anos, em 1990, para 6,4 anos em 2000 e 7,5 anos em 2010), em 2010 o Brasil tinha a pior média de anos de escolaridade dentre todos os países elencados (à exceção da Venezuela). Em 2010, com uma média de 7,5 anos de estudo, o país estava muito atrás da média asiática $(10,7)$ e também da média da América Latina, de 8,7 anos de estudo. A Tabela 5 também é elucidativa, pois em 2010 o país tinha $33,7 \%$ da população acima de 15 anos com pelo menos o ensino secundário completo, enquanto a média dos países asiáticos era quase o dobro $(61,2 \%)$ no mesmo ano. Confrontados com os dados do Brasil, os dados da China, entre 1950 e 2010, revelam a diferença de trajetória pois, partindo de um patamar muito mais baixo do que o do Brasil em 1950, a China alcançou $55 \%$ da população acima de 15 anos com ensino secundário completo em 2010, enquanto o Brasil chegou a apenas 33,7\%.

O estudo citado resume bem o caráter intermediário (ou seja, semiperiférico) do Brasil, do ponto de vista educacional, pois mostra que os Tigres Asiáticos 
realizaram investimentos significativos em educação, e assim reduziram a distância em relação aos países desenvolvidos. Segundo os autores,

O país [o Brasil] apresentou durante várias décadas elevadas taxas de crescimento econômico, que indicavam que poderia alcançar a renda per capita das economias desenvolvidas. Entretanto, no mesmo período em que o diferencial de renda per capita se reduzia, não houve redução no diferencial de anos médios de escolaridade em relação aos países desenvolvidos. Essa carência relativa de capital humano pode ter contribuído para manter o país com uma renda média. Em um mundo com tecnologias mais viesadas para trabalhadores mais qualificados, esse diferencial pode dificultar a adoção das novas tecnologias e reduzir as chances de o Brasil alcançar a renda per capita dos países desenvolvidos. (BARBOSA FILHO, MOURA, 2013, p. 118, grifos nossos)

Castro (2015) também ressalta o hiato em recursos humanos no Brasil, mostrando que a estrutura industrial em nosso país não estimula a formação de um montante significativo de força de trabalho qualificada, o que se relaciona com o peso da exportação de produtos primários ou pouco elaborados, o que acaba produzindo um círculo vicioso:

a economia brasileira segue especializada em recursos naturais, alguns com altíssima capacidade tecnológica, outros nem tanto, mas a especialização em recursos primários é inconteste. Parte dos equipamentos e dos bens de capital, assim como a microeletrônica, são importadas. A dependência de certas importações contribui para a baixa geração de externalidades e para a incompleta estrutura produtiva. Existe, ainda, uma grande heterogeneidade na estrutura produtiva brasileira, na qual convivem setores de baixa tecnologia com setores de alta tecnologia. A mão de obra ainda é, em grande medida, pouco qualificada, e raramente o setor de máquinas e equipamentos se encontra na fronteira tecnológica. (CASTRO, 2015, p. 19-20, grifos nossos)

Os resultados do Programme for International Student Assessment (PISA), para o ano de 2015, também mostram o atraso relativo do Brasil em termos educacionais. Esse exame, que avalia os conhecimentos de estudantes de 15 anos de idade em ciência, leitura e matemática, foi feito em 70 países no ano de 2015. O Brasil ficou na $63^{a}$ posição, com uma performance média em cada um dos quesitos, muito abaixo da média da OCDE. Em ciências, a média brasileira, de 401 pontos, foi comparável a dos estudantes da Indonésia e Peru. Em leitura, a média brasileira, de 407 pontos, foi comparável à obtida por estudantes da 
Albânia, Geórgia, Qatar e Tailândia. E, em matemática, a média brasileira (377 pontos) foi comparável com a obtida por estudantes da Iugoslávia, Macedônia e Jordânia (PISA, 2015, p. 2-3).

O mesmo documento descreve o desempenho dos estudantes brasileiros nos três quesitos acima mencionados. Na OCDE, $20 \%$ dos estudantes não atinge o nível de leitura que habilita "participar efetiva e produtivamente da vida". No Brasil, metade dos estudantes não atinge tal nível (PISA, 2015, p. 3). Enquanto $8,3 \%$ estudantes da OCDE obtiveram performance máxima em leitura, no Brasil esse percentual foi de apenas $1,4 \%$.

Em matemática, os resultados são ainda piores. Na OCDE, perto de $25 \%$ dos estudantes não atinge o nível básico de proficiência. No Brasil, são 70\% (PISA, 2015, p. 4). A performance máxima no teste de matemática foi obtida por 1 estudante para cada 10 estudantes, para os países da OCDE. E, no Brasil, essa performance máxima foi obtida apenas por 1 entre 100 estudantes. Essa proporção, 10 vezes inferior à média da OCDE, vem sendo mantida desde 2003.

Por fim, no que tange ao desempenho em ciências, a média da OCDE em resultados abaixo do nível básico de proficiência foi de $20 \%$ dos estudantes. Para o Brasil, a proporção de estudantes com baixo desempenho nesse quesito é quase três vezes maior do que a média da OCDE, em uma proporção que não se alterou desde 2006. A performance máxima em ciências foi obtida por $8 \%$ dos estudantes da OCDE, e por menos de $1 \%$ dos estudantes no Brasil, um percentual significativamente mais baixo, e que vem se mantendo inalterado desde 2006. Em resumo, pode-se dizer, em conformidade com o The Global Competitiveness Report 2014-2015, documento do World Economic Forum, que o Brasil tem “...um sistema de educação pobre $\left(126^{\circ}\right)$ que não fornece aos trabalhadores o conjunto de habilidades necessárias para uma economia em transição para atividades mais baseadas em conhecimento" (p. 32) ${ }^{17}$.

Indicadores de ciência e tecnologia, que são estreitamente ligados à questão educacional, evidenciam posições precárias do Brasil ${ }^{18}$, que refletem também sua histórica condição periférica até mais ou menos 1950 e, desde então, semiperiférica. As Tabelas 6 (Patentes requeridas por residentes) e 7 (Indicadores ligados à inovação) mostram como o Brasil já ficou para trás em indicadores básicos nesse campo.

\footnotetext{
17 “...a poor education system (126th) that fails to provide workers with the necessary set of skills for an economy in transition toward more knowledge-based activities” (World Economic Forum, 2015, p. 32)

18 "Human capital is a major innovation system bottleneck in Brazil” (OECD, 2014, p. 282).
} 
Tabela 6 - Patentes requeridas por residentes

\begin{tabular}{lrrrrrrrr}
\hline & $\mathbf{1 9 7 0}$ & $\mathbf{1 9 8 0}$ & $\mathbf{1 9 9 0}$ & $\mathbf{1 9 9 5}$ & $\mathbf{2 0 0 0}$ & $\mathbf{2 0 0 5}$ & $\mathbf{2 0 1 0}$ & $\mathbf{2 0 1 4}$ \\
\hline Argentina & 1.982 & 1.269 & 955 & 676 & 1.062 & 1.054 & 552 & 509 \\
Brasil & 3.839 & 2.149 & 2.389 & 2.707 & 3.179 & 4.054 & 4.228 & 4.659 \\
China &.. &.. & 5.832 & 10.011 & 25.346 & 93.485 & 293.066 & 801.135 \\
Japão & 100.513 & 165.730 & 332.952 & 333.770 & 384.201 & 367.960 & 290.081 & 265.959 \\
Coreia do Sul & 1.202 & 1.241 & 9.082 & 59.228 & 72.831 & 122.188 & 131.805 & 164.073 \\
\hline
\end{tabular}

Fonte: World Bank, 2016.

Em perspectiva relativa e comparativa, o baixo número de patentes registradas por residentes brasileiros parece revelar um quadro ainda mais preocupante:

Entre 2000 e 2010, a participação do Brasil nas patentes mundiais concedidas pela USPTO manteve-se estável, em torno de 0,07\%. Em uma comparação com 75 países, na relação de pedidos de patentes por residente como percentual do PIB, em 2010 o Brasil ficou em 54 lugar, com 1,38 patentes por US\$ bilhão. E em termos de patentes por habitante, o Brasil ficou em $55^{\circ}$ lugar entre 82 países $(13,9$ patentes por milhão de habitantes). Em ambos os casos, o Brasil ficou abaixo da classificação média dos países. E apenas 6,1\% das empresas inovadoras nacionais solicitaram patentes durante o período 2006-2008; essa participação atingiu 26,4\% para empresas estrangeiras e $36,5 \%$ para joint- ventures entre empresas nacionais e estrangeiras. (ZUNIGA et al, 2016, p. 16) ${ }^{19}$

O Brasil também está muito defasado em outros indicadores ligados à inovação, como pode ser visto na Tabela 7. Além do menor número em comparação com a maioria dos países listados na referida tabela, os pesquisadores brasileiros produzem menos patentes do que seus congêneres em outros países, em termos de patente por pesquisador (PINHEIRO, 2013). A disponibilidade de engenheiros e cientistas é outro ponto que evidencia o atraso do Brasil, em perspectiva comparada. Como se vê na Tabela 7, em 2012, em um total de 144 países, o Brasil ficou na posição 113, à frente apenas da África do Sul (122). O score do Brasil, nesse quesito, é claramente intermediário: 3,5 (na escala de 0 a 7). Tal resultado é confirmado por um documento do Instituto de Estudos do Desenvolvimento Industrial, IEDI (2011), que comparou o ensino superior da China com o do Brasil:

19 “Between 2000 and 2010, Brazil's share of world patents granted by USPTO remained stable, at a round 0,07 percent. In a comparasion with 75 other countries, Brazil ranked 54th in 2010 in terms of resident patent applications as a share of GDP, at 1.38 patents per US\$ billion. And in terms of patents per population, Brazil ranked 55th among 82 countries (13.9 patents per million inhabitants). In both cases, Brazil ranked below the average country rank. And only 6.1 percent of national innovative firms applied for patents over the 2006-2008 period; this share reached $26.4 \%$ for foreign firms and 36.5 percent for joint national and foreign-owned enterprises”. (ZUNIGA et al, 2016, p. 16) 
A grande diferença entre os sistemas de ensino superior dos dois países está exatamente no perfil dos egressos: na China, 5,0\% destes egressos se formam na área de ciências e 36,1\% em engenharia (formação integral e de três anos) (...) No Brasil, os percentuais equivalentes são de $7,8 \%$ e $6,7 \%$, respectivamente. Em termos absolutos, as diferenças são marcantes. Os egressos em ciências e engenharia na China, em 2009, eram mais de 1 milhão de jovens em cursos de formação plena e outros 1,1 milhão em cursos de tecnólogos (três anos), enquanto no Brasil os egressos nas áreas de ciência e engenharia eram de aproximadamente 120 mil jovens, incluindo a formação plena e tecnológica. (IEDI, 2011, p. 11)

Tabela 7 - Indicadores ligados à inovação - 2010*

\begin{tabular}{|c|c|c|c|c|}
\hline & $\begin{array}{l}\text { Pesquisadores em } \\
\text { P\&D (por milhão } \\
\text { de habitantes) }\end{array}$ & Patentes & $\begin{array}{c}\text { Disponibilidade de } \\
\text { engenheiros e cientistas } \\
\text { (escala de } 0 \text { a } 7)\end{array}$ & $\begin{array}{l}\text { Patentes por } \\
\text { pesquisador } \\
\left(\begin{array}{l}x \\
1000)\end{array}\right.\end{array}$ \\
\hline BRICS & 1.104 & 4,5 & 4 & 7,4 \\
\hline Brasil & 696 & 2,8 & $3,5[113]$ & 4 \\
\hline Rússia & 3.091 & 5,4 & $3,8[90]$ & 1,7 \\
\hline Índia & 136 & 1,2 & $5,0[16]$ & 8,6 \\
\hline China & 1.199 & 6,5 & $4,4[46]$ & 5,4 \\
\hline África do Sul & 396 & 6,8 & $3,4[122]$ & 17,2 \\
\hline América Latina & 476 & 1,9 & 4,1 & 5,9 \\
\hline Argentina & 1.046 & 1,1 & $3,9[80]$ & 1 \\
\hline Chile & 355 & 3,8 & 4,7 [29] & 10,7 \\
\hline Colômbia & 157 & 1,1 & $3,7[94]$ & 7,2 \\
\hline México & 347 & 1,6 & $4,0[71]$ & 4,7 \\
\hline Leste e Sudeste Asiático & 3.476 & 98 & 4,9 & 26,6 \\
\hline Cingapura & 5.834 & 123,2 & $5,1[13]$ & 21,1 \\
\hline Coreia do Sul & 4.947 & 161,1 & $4,9[23]$ & 32,6 \\
\hline Hong Kong & 2.759 & & $4,6[36]$ & \\
\hline Malásia & 365 & 9,6 & $4,9[20]$ & 26,2 \\
\hline Desenvolvidos & 3.821 & 103,6 & 5 & 26,9 \\
\hline Alemanha & 3.780 & 203,6 & $4,5[40]$ & 53,9 \\
\hline Canadá & 4.335 & 77,6 & $5,4[6]$ & 17,9 \\
\hline Espanha & 2.932 & 35,4 & $5,0[18]$ & 12,1 \\
\hline Estados Unidos & 4.673 & 137,9 & $5,4[5]$ & 29,5 \\
\hline França & 3.690 & 110,2 & $4,9[22]$ & 29,9 \\
\hline Itália & 1.690 & 51,7 & $4,5[45]$ & 30,6 \\
\hline Japão & 5.189 & 210,7 & $5,7[2]$ & 40,6 \\
\hline Portugal & 4.308 & 12,2 & $4,7[31]$ & 2,8 \\
\hline Reino Unido & 3.794 & 93 & $5,1[12]$ & 24,5 \\
\hline
\end{tabular}

FONTE: baseado em Pinheiro (2013). Entre colchetes, a colocação do país em termos mundiais.

*Quando os dados de 2010 não estão disponíveis, usou-se a informação mais recentemente publicada. Exceção para a disponibilidade de engenheiros e cientistas, que se refere a 2012. 
Outro estudo identifica a carência na formação de engenheiros como uma grande desvantagem das empresas brasileiras no tocante à inovação:

Enquanto $50 \%$ dos pesquisadores do Japão e cerca de $65 \%$ na Rússia e na Coréia do Sul estão nos campos da engenharia e da tecnologia, no Brasil apenas $20 \%$ dos pesquisadores pertencem a engenharia e tecnologia. (...) No geral, apenas $6 \%$ dos pesquisadores do sistema educacional brasileiro estão dedicados à engenharia “ (ZUNIGA et al 2016, p. 40)20

Esse atraso relativo em educação e em ciência e tecnologia parece constituir uma estrutura de longa duração da economia e sociedade brasileiras. Afinal,

um dos traços mais notáveis das atividades econômicas desenvolvidas no território brasileiro desde o século XVI foi a ausência de inovação, ou talvez fosse melhor dizer, a resistência a elas, isso em todos os âmbitos da vida social. (VIEIRA, FERREIRA, 2013, p. 263)

As consequências dessa afirmação não devem ser negligenciadas. Como assinalado por Pinheiro, ao discutir os fundos setoriais de ciência e tecnologia no Brasil, “a baixa propensão ao investimento em $P \& D$ das empresas é justamente a maior debilidade do sistema brasileiro de inovação” (PINHEIRO, 2013, p. 93). Embora, mais recentemente, os investimentos brasileiros em P\&D sejam superiores aos de países de renda similar, e próximos aos de alguns países desenvolvidos, “o Brasil destoa no que diz respeito à participação das empresas privadas nos investimentos em $\mathrm{P} \& \mathrm{D}$, muito pequena em comparação com a maioria dos países desenvolvidos e do Leste e Sudeste Asiático” (idem, 100).

O estudo de Zuniga et alli (2016, p. 15, grifos nossos) também faz um balanço crítico das condições para a inovação no Brasil. De acordo com esse documento

na inovação, de acordo com vários indicadores, o desempenho do Brasil é intermediário, ficando atrás de economias similares como Rússia e China. O Brasil ocupa o $61^{\circ}$ lugar no Índice de Inovação Global, muito atrás da Irlanda $\left(11^{\circ}\right)$, da China $\left(29^{a}\right)$, de Portugal $\left(32^{a}\right)$ e da Rússia $\left(49^{a}\right) .{ }^{21}$

20 "Whereas 50 percent of researchers in Japan and about 65 percent in Russia and South Korea are in the fields of engineering and technology, in Brazil only 20 percent of total researchers belong to engineering and technology. (...) Overall, only 6 percent of researchers in the Brazilian educational system are dedicated to engineering”. (ZUNIGA et al 2016, p. 40)

21 "In terms of innovation performance, according to several indicators, Brazil performs in the medium range behind peer economies such as Russia and China. Brazil ranks in 61th place in the Global Innovation Index far behind Ireland (11th), China (29th), Portugal (32th) and Russia (49th)”. (ZUNIGA et al, 2016, p. 15) 
A baixa posição do Brasil nesse ranking relaciona-se com a própria natureza da inovação nas empresas dentro do país:

A natureza da inovação das empresas brasileiras é principalmente de recuperação do atraso e não de fronteira. A maioria das inovações introduzidas pelas empresas brasileiras consiste de adaptações e incrementos de tecnologias existentes, que são 'novas para as firmas' ou 'novas para o mercado nacional', devendo, portanto, mais apropriadamente serem classificadas como inovações recuperadoras do atraso e não como fronteiras ou 'novas para os mercados globais". (ZUNIGA et al 2016, p. 16)22

A capacidade para imitar, mas não para inovar, talvez seja mais um traço da posição intermediária ou semiperiférica do Brasil, que não foi capaz de acompanhar as mudanças exigidas e produzidas pelo paradigma produtivo e tecnológico que emergiu nos anos de 1980. Desde então, de acordo com Amsden (2009), enquanto países do Leste Asiático (os “independentes”, na terminologia da autora) desenvolveram tecnologias próprias, países como o Brasil limitaram-se a comprar as tecnologias (os "integracionistas").

A própria evolução da composição da pauta exportadora brasileira evidencia as dificuldades do país em direção a níveis mais elevados de sofisticação produtiva. De fato, os dados disponíveis para o período compreendido entre 1995 e 2015 mostram o contrário: o predomínio de exportações de produtos primários e de baixo valor agregado, em particular a partir do início dos anos de 2000, quando ocorre um boom no preço das commodities (soja, minério de ferro, petróleo cru, açúcar e carne de frango) ${ }^{23}$. Essa situação é revelada pelo Atlas da Complexidade Econômica (2017): entre 124 países analisados, o Brasil estava na 30a posição nesse indicador em 1995, e passou para a 54a posição em 2014) 24, em uma posição efetivamente intermediária.

Portanto, a persistência e mesmo predominância dessa pauta produtiva e exportadora, que, diga-se de passagem, são características históricas do Brasil, ao

22 "The nature of innovation by Brazilian firms is mostly catch-up rather than frontier innovation. Most of the innovations introduced by Brazilian business consist of the commercialization of adaptive and incremental 'new to the firm' or 'new to the national market' existing Technologies, hence are appropriately classified as catch-up rather than more frontier or 'new to global markets' innovations”. (ZUNIGA et al, 2016, p. 16)

23 Informações de 2015, coletadas no The Observatory of Economic Complexity (www.atlas.media.mit.edu/Brazil), consultado em 30.08.2017.

24 Fonte: www.atlas.cid.harvard.edu, consultado em 05.05.2017. 
mesmo tempo que expressa as deficiências educacionais, científico-tecnológicas e de inovação acima apresentadas, tende a reforçar tais deficiências ao atrair investimentos e apoio político e social principalmente para essas atividades e não para aquelas que poderiam trazer características relacionadas a avanços em tecnologias e inovações próprias. Tal situação se choca com a necessidade de abrigar empresas inovadoras, exigência indispensável para aqueles países que querem (e mesmo que conseguiram) ultrapassar as fronteiras da condição semiperiférica e alcançar o padrão de riqueza do centro, como argumentado por Arrighi (1997) e demonstrado por Amsden (2009).

A percepção das dificuldades do Brasil no campo da inovação é sintetizada adequadamente por Castro (2015), para quem a ausência de inovação se deve à defasagem na formação de recursos humanos em relação ao investimento em capital fixo:

Quanto aos gargalos, em primeiro lugar parece estar a formação de recursos humanos para a indústria. Existe um permanente investimento em capital que não encontra necessariamente sua contrapartida nos recursos humanos. Há claramente um hiato em recursos humanos no Brasil, como na Argentina; lá, em maior medida. A estrutura industrial não induz a formação significativa de recursos humanos. O aumento do investimento implica a formação de capital fixo que se renova, mas que tem rápida obsolescência. Tende a acontecer uma rápida perda de competitividade: a atualização de máquinas e equipamentos sem a necessária capacidade tecnológica para saltar etapas, obter novas patentes e criar ativos intangíveis implica possuir um conjunto de inovações que geram menor valor agregado na fronteira, ou que rapidamente perdem o valor agregado adicionado. (CASTRO, 2015, p. 19-20)

O contraste com países do Leste Asiático é notório, como mostrado por Romero et al. (2015), que compararam a competitividade industrial do Brasil com a da Coreia do Sul. A perda de dinamismo dos produtos de alta tecnologia na pauta exportadora de manufaturados é também um indicador de que o país continua ficando para trás e mantendo sua especialização histórica em produtos de baixo e médio valor agregados. Isso obviamente associa o país a fases menos complexas e rentáveis das cadeias globais de valor.

Estudo recente da OCDE, citado pelo documento Carta IEDI n. 578 (de 28.06.2013), mostra que a distribuição espacial das cadeias manufatureiras nas últimas duas décadas se deu de forma assimétrica: 
Não somente as economias centrais perderam posição no valor agregado manufatureiro; também economias emergentes industrializadas como o Brasil diminuíram sua participação na produção mundial de valor adicionado industrial. Os ganhadores na disputa da concorrência global para a recepção de investimentos de firmas transnacionais foram os asiáticos sob a liderança chinesa. (IEDI, 2013, p. 1)

O mesmo documento também afirma que o Brasil e o restante da América Latina (com exceção do México) ficaram praticamente à margem da reorganização das cadeias globais de valor, destacando nosso pouco peso nas cadeias globais e a integração produtiva regional pouco significativa. Além disso,

De acordo com o relatório da OCDE e OMC, o Brasil é uma das economias com menor valor adicionado estrangeiro nas suas exportações, da ordem de $10 \%$, o que é um indicador para trás nas cadeias de valor. É um indicador também de que a economia brasileira é fechada, ou porque é forte na produção doméstica de matérias-primas e bens intermediários, ou porque produz relativamente poucos bens que demandam componentes vindos do exterior ou ainda porque somos uma economia protegida. Contudo, a contribuição brasileira enquanto valor adicionado nas exportações dos outros países, um indicador para frente da integração nas CGVs, é a segunda maior entre os países em desenvolvimento, principalmente por conta das exportações de insumos e matérias-primas. O comentário pertinente sobre estas constatações é que o Brasil não está totalmente fora das CGVs, mas seu lugar é mais como fornecedor de insumos para empresas de outras origens adicionarem mais valor na cadeia produtiva, do que como exportador de produtos com maior valor adicionado. (IEDI, 2013, p. 1, grifos nossos).

A respeito das commodities, basta mencionar que a maior parte das exportações do Brasil é de baixo valor agregado. Ou seja, o Brasil vende menos aço e mais minério de ferro, assim como vende mais petróleo bruto do que refinado e mais grãos de soja do que farelo e óleo de soja. E mesmo esforços recentes de internalizar a cadeia produtiva do petróleo, através do Marco Regulatório do PréSal, vêm sofrendo ataques nos últimos anos, tanto na esfera estatal quando na esfera do capital internacional, como destacado por Ouriques, Schmidt (2015) ao mostrarem, com o caso do petróleo, a dificuldade que um país semiperiférico tem em se inserir nos elos mais rentáveis das cadeias globais de valor. O fato é que o Brasil, efetivamente, apresenta um grau intermediário de especialização produtiva em alguns setores de alta tecnologia, mas não se tornou competitivo em termos globais, como relatado pelo estudo de Nonnenberg (2013) 
Bértola, Ocampo (2013) e Amsden (2009) destacaram, em particular, as deficiências históricas da América Latina em relação aos países do centro em termos educacionais. As observações desses autores são corroboradas pelos poucos dados aqui apresentados e ajudam a compreender por que o Brasil não conseguiu e não consegue ascender no sistema interestatal, permanecendo na condição semiperiférica. Sendo as atividades inovadoras a chave para o sucesso na trajetória desenvolvimentista, entendida como mudança de posicionamento de um dado Estado no sistema global, a participação do Brasil em algumas poucas atividades dessa natureza e o predomínio de atividades produtivas que agregam pouco valor serve como indicativo de uma situação verdadeiramente intermediária na economia global, aliada ao posicionamento semiperiférico em termos de PNB e PIB per capita, expresso nos estudos de Arrighi, Drangel (1997), Arrighi et al (1996) e Lima (2007a e 2007b).

\section{Conclusões}

Quando concebeu a noção de semiperiferia, Wallerstein (1979) considerou o Brasil como um Estado semiperiférico. Quando submeteram tal noção a uma verificação empírica com base em séries históricas dos indicadores de PNB per capita, Arrighi, Drangel (1997) confirmaram a proposição de Wallerstein. Estudando somente o Brasil, Lima (2007) concluiu que o país se comportou como membro da zona semiperiférica ao longo o período 1950-2003. Com essa mesma metodologia, estendemos o horizonte temporal para 2014 e corroboramos a conclusão desse último autor. De fato, de 1950 a 2014, o Brasil se manteve na condição semiperiférica, pois, ao longo desses 54 anos, o PIB per capital brasileiro oscilou entre $20 \%$ e $30 \%$ do PIB per capita dos EUA, conforme indicado no Gráfico 1. Neste artigo, nosso objetivo foi apresentar outros indicadores e também argumentos que parecem reforçar a hipótese da condição semiperiférica do Brasil na economia-mundo capitalista.

Os indicadores de educação e ciência e tecnologia apresentados neste artigo mostram uma situação oscilando entre periférica e semiperiférica (intermediária). Apesar do esforço das últimas décadas, o Brasil ainda não conseguiu atingir patamares similares de, inclusive, países que estavam em condições semelhantes ou mesmo piores nos anos de 1950 (como os chamados Tigres Asiáticos e, mais recentemente, a China). Os dados mostram que, em relação a tais países, o 
Brasil continua "ficando para trás", o que também indica a manutenção de seu posicionamento semiperiférico na economia-mundo capitalista, posicionamento que pode estar sendo ameaçado, na medida em que alguns dos indicadores de ciência, tecnologia e educação aqui apresentados caracterizam uma situação muito precária do Brasil, típica de condição periférica.

Ora, a conjuntura mais recente (a partir do início dos anos 2000) foi pautada pelo boom das commodities, determinado pela demanda chinesa, que impactou positivamente o setor exportador brasileiro (minérios e agronegócio). Além disso, os programas de transferência de renda praticamente extinguiram a pobreza extrema no país e também diminuíram um pouco a histórica desigualdade na distribuição da renda. Possivelmente, essa transferência de renda foi um importante mecanismo de compensação para a fragilidade nos indicadores de ciência, tecnologia e educação apresentados neste artigo, garantindo a manutenção do status semiperiférico do Brasil, pois ajudou a aumentar a renda per capita no curto período 2001-2011, segundo o IPEA (Instituto de Política Econômica Aplicada) ${ }^{25}$. E, como o país mantém invejável posição mundial em nichos muito específicos (agronegócio, petróleo e um setor específico do ramo aeroespacial), consegue manter sua posição econômica intermediária no sistema interestatal.

Como apresentado, o Brasil está em uma posição intermediária na disponibilidade de engenheiros e cientistas (um indicador de inovação) no Global Innovation Index (61 a posição) e também no Atlas da Complexidade Econômica (54ª posição em 2014). E, ao mesmo tempo, em situação periférica em alguns indicadores educacionais e no Coeficiente de Gini. Assim, há um misto de indicadores semiperiféricos e periféricos, elencados neste artigo. Cotejando esses dados com a posição intermediária em termos de PIB per capita, e com base nos dados, interpretações de autores e documentos aqui citados, podemos inferir que o Brasil pode ser classificado como um Estado semiperiférico, estando na posição intermediária no sistema interestatal. Contudo, a questão que permanece em aberto diz respeito ao caráter dessa posição. Isto é, o Brasil pode ser classificado como membro "orgânico" da semiperiferia?

Embora uma queda para a periferia não possa ser descartada - o gráfico 1 mostra que, desde 1980, a relação PIB per capita brasileiro/PIB per capita dos EUA vem caindo (com exceção dos anos de 2005-2014) —, é necessário aprofundar a

25 De acordo com o relatório "Vozes da Nova Classe Média”, do IPEA (2013), entre 2001 e 2011 a renda per capita das famílias brasileiras aumentou 32,6\% (2,9\% ao ano), devido principalmente à expansão do mercado de trabalho e às políticas de transferência de renda. 
pesquisa para avaliar tal possibilidade. Esse aprofundamento consistiria em estudar comparativamente a evolução de indicadores chaves no Brasil e nos países centrais e naqueles que parecem se movimentar em direção ao centro, para avaliar se a defasagem brasileira configuraria uma posição periférica. Nesse sentido, além de indicadores educacionais, de produtividade e de ciência, tecnologia e inovação, seriam também muito úteis estudos de cadeias de valor específicas, bem como estatísticas comparadas a respeito de indicadores sociais e de bem-estar da população e também de distribuição interna da renda.

No que tange à comparação, devem ser levadas em conta tanto as condições sistêmicas quanto internas que favorecem ou dificultam o catching-up por um determinado país. Nesse sentido, no caso da América Latina, parecem cobrar grande peso o passado colonial e, desde pelo menos 1930, a enorme influência econômica e políticas dos EUA na região, que dificultam tanto o desenvolvimento de empresas nacionais líderes quanto a formação de lideranças políticas capazes e dispostas a defender as demandas nacionais em organismos internacionais. Esse último aspecto traz à tona a necessidade de analisar a dimensão política da condição semiperiférica. Isto é, estudar a "turbulência política” das semiperiferias em geral, e do Brasil em particular, ficando essa tarefa para uma pesquisa futura.

\section{Referências}

AMSDEN, Alice. A ascensão do resto. São Paulo, Editora da UNESP, 2009. Atlas da Complexidade Econômica. Disponível em: www.atlas.cid.harvard.edu, consultado em 05.05.2017.

AREND, Marcelo. O Brasil e o longo Século XX: condicionantes sistêmicos para estratégias nacionais de desenvolvimento. In: VIEIRA, Rosângela L. (org.). O Brasil, a China e os EUA na atual conjuntura da economia-mundo capitalista. Marília, Cultura Acadêmica, 2013, p. 135-171.

ARRIGHI, Giovanni; DRANGEL, Jessica. A estratificação da economia mundial: considerações sobre a zona semiperiférica. In: ARRIGHI, G. A ilusão do desenvolvimento. Petrópolis, Vozes, 1997, p. 137-206.

ARRIGHI, Giovanni. A ilusão desenvolvimentista: uma reconceituação da semiperiferia. In: Arrighi, G. A ilusão do desenvolvimento. Petrópolis, Vozes, 1997, p. 137-206.

ARRIGHI, Giovanni et al. Modeling zones of the World-Economy: a polymonial regression analysis (1964-1994). Paper presented at the 1996 Annual Meeting of the American Sociological Association, 1996. 
BARBOSA FILHO, Fernando H.; MOURA, Rodrigo L. Educação e desenvolvimento no Brasil . In: Pereira, L.V.; Veloso, F.; Bingwen, Z. (org.). Armadilha da renda média - visões do Brasil e da China. Rio de Janeiro, Editora da FGV, volume 1, 2013, p. 107-133.

BERNARDES, Roberto. O caso Embraer - privatização e transformação da gestão empresarial: dos imperativos tecnológicos à focalização no mercado. São Paulo, CYTED:PGT/USP, Cadernos de Gestão Tecnológica, n. 46, 2000.

BÉRTOLA, Luis; OCAMPO, José A. Desenvolvimento, vicissitudes e desigualdade: uma história econômica da América Latina desde a Independência. Madrid, Secretaría General Iberoamericana, 2013.

BOLT, J.; VAN ZANDES J. L. The first update of the Maddison Project: re-estimating growth before 1820. Maddison Project, Working Paper 4. Disponível em: www.ggdc. net/maddison, 2013.

CASTRO, Ana Célia. Políticas de inovação e capacidades estatais comparadas: Brasil, China e Argentina. In: IPEA, Texto para Discussão, Rio de Janeiro, jul, n. 2106, 2015, 43 p.

CUMINGS, Bruce. The Origins and Development of Northeast Asian political economy: industrial sectors, product cyles and political consequences. In: International Organization, 38, 1, 1984, pp. 1-40. Disponível em: bev.berkeley.edu, Acesso em: 05.07.2017.

FIORI, José L. O nó cego do desenvolvimento brasileiro. In: Novos Estudos, São Paulo, n. 40, 1994, pp. 125-144.

GOLDENSTEIN, Lidia. Repensando a dependência. São Paulo, Paz e Terra, 1994, 173p.

HUMAN DEVELOPMENT REPORT. Human Development for Everyone. 2016 Published for the United Nations Development Programme (UNDP). Disponível em: www.hdr. undp. org

IEDI (Instituto de Estudos para o Desenvolvimento Industrial). Uma comparação entre a agenda de inovação da China e do Brasil. São Paulo, novembro, 2011, 21 p.

IEDI (Instituto de Estudos para o Desenvolvimento Industrial). O lugar do Brasil nas cadeias globais de valor. São Paulo, Carta IEDI, n. 578, 28.06.2013, 2013, 20 p.

IPEA. Vozes da nova classe média. Brasília, Instituto de Pesquisa Econômica Aplicada, 2013.

KORZENIEWICZ, Roberto P. ; MORAN, Timothy P. . World-economic trends in the distribution of income 1965-1992. American Journal of Sociology, vol. 102, n. 4, 1997, pp. 1000-1039. Disponível em: journals.uchicago.edu, Acesso em: 14.06.2017.

LIMA, Pedro Garrido C. Posicionamento no sistema mundial e semiperiferia: evidências empíricas por meio de análise exploratória de dados no período 1950-2003. Niterói, Universidade Federal Fluminense, Dissertação de Mestrado, 2007 a. 
LIMA, Pedro Garrido C. Posicionamento no sistema mundial e semiperiferia. In: Textos de Economia, Florianópolis, volume 10, número 2, jul./dez., 2007 b, p. 58-85. Disponível em: periodicos.ufsc.br/index.php/economia/article/viewFile/1851/1614, Acesso em: 10.07.2017.

NONNENBERG, Marcelo J.B. Integração produtiva, fragmentação da produção e evolução do comércio internacional: como evoluíram os países da Ásia e América Latina?. In: Textos para Discussão, IPEA, Rio de Janeiro, n. 1905, dezembro, 2013, 24 p.

OECD. Science, Technology and Industry Outlook 2014. OECD Publishing, 2014, 480 p. Disponível em: www.oecd.org/sti/outlook

OURIQUES, Helton R.; SCHMIDT, Cristiane B. O pré-sal no Brasil: oportunidade de ‘upgrading’ ou ilusão desenvolvimentista? In: Século XXI, Porto Alegre, v. 6, n. 2, jul./dez., 2015, p. 13-33. Disponível em: seculoxxi.espm.br/index.php/xxi/article/ viewFile/118/118, Acesso em: 20.06.2017.

PEACOCK, Walter Gillis et al. Divergence and convergence in international development: a decomposition analysis of inequality in the World-system. American Sociological Review, vol. 53, december, 1988, p. 838-852.Disponível em jstor.org/stable/i336569, Acesso em: 20.07.2017.

PEINADO, Javier M. La semiperiferia como necesidad del capitalismo global: una aproximación a través del análisis factorial. Revista de Economía Mundial, n. 38, 2014, p. 253-272. Disponível em: redalyc.org/pdf/866/86632965011.pdf, Acesso em: 20.07.2017.

PINHEIRO, Maurício C. Inovação no Brasil: panorama geral, diagnóstico e sugestões de política. In: Pereira, L.V.; Veloso, F.; Bingwen, Z. (org.). Armadilha da renda média - visões do Brasil e da China. Rio de Janeiro, Editora da FGV, volume 1, 2013, p. 81-106.

PISA (Programme For International Student Assessment). BRAZIL - Results from PISA 2015. 13 f., Disponível em: www.oecd.org.edu/pisa, 2015.

ROMERO, J. et al. The great divide: the paths of industrial competitiveness in Brazil and South Korea. Belo Horizonte, UFMG/CEDEPLAR, 2015, 34 p. [Texto para Discussão, 519]

SENNES, Ricardo U. Potencia média recém industrializada: parâmetros para analisar o Brasil. In: Contexto Internacional, Rio de Janeiro, v. 20, n. 2, 1998. Disponível em: contextointernacional.iri.puc-rio.br/media/Sennes_vol20n2.pdf. Acesso em: 10.08.2017.

SHIE, Vincent H.; WENG, Chih-Yuan. . Destabilizing the semiperiphery: the counterturn of China's ascendence in the World-Economy. Perspectives on Global Development and Technoloy, n. 10, 2011, p. 365-385. Disponível em: booksandjournals.brillonline. com/content/.../156914911x610367. Acesso em: 22.06.2017. 
TERLOUW, C.P. The elusive semiperiphery: a critical examination of the concept semipheriphery. International Journal of Comparative Sociology. XXXIV, 1-2, 1993, p. 87-102. Disponível em: home.kpn.nl/C.Terlouw5/The\%20elusive\%20semiperiphery.pdf. Acesso em: 22.06.2017.

THE OBSERVATORY OF ECONOMIC COMPLEXITY OEC. Disponível em: www.atlas. media.mit.edu/Brazil, consultado em 30.08.2017.

THE WORLD BANK. World Bank Open Data. Disponível em: data.worldbank.org. Acesso em: 20.11.2016.

VIEIRA, Pedro A.; FERREIRA, Luiz Mateus S. O Brasil na atual conjuntura científicotecnológica da economia mundo capitalista. In: VIEIRA, Rosângela de Lima (Org.). O Brasil, a China e os EUA na atual conjuntura da economia-mundo capitalista. Marília, Oficina Universitária; São Paulo, Cultura Acadêmica, 2013, p. 247-278.

WALLERSTEIN, Immanuel. El moderno sistema mundial - la agricultura capitalista y las orígenes de la economía-mundo europea en el siglo XVI. México, Siglo XXI, 2a ed. aum., vol. 1, 2011, 580p.

WALLERSTEIN, Immanuel. The capitalist World-Economy. New York, Cambridge University Press, 1979, 305p.

WORLD ECONOMIC FORUM. The global competitiveness report 2014-2015. Geneva, 2015, 565p.

ZUNIGA, Pluvia et al. Conditions for innovation in Brazil: a review of key issues and policy challenges. In: IPEA. Institute for Applied Economic Research. Discussion Paper n. 218, Brasília, November, 2016, 102 p. 


\title{
Energiewende: german energy policy in times of green transition
}

\section{Energiewende: política energética alemã em tempos de transição verde}

DOI: $10.21530 /$ ci.v12n3.2017.649

Solange Reis ${ }^{1}$

\begin{abstract}
Germany has developed an ambitious strategy to increase the share of renewable sources in its energy matrix and to enable the transition to a green industrial paradigm. Known as Energiewende, the policy implied profound structural transformations in the energy system. Participation of the residents and of small entrepreneurs stands out among its particularities. The state leads the transitional project by mediating the divergent interests among social and economic agents. The challenge is to maintain social consensus despite unequal costs. Individual consumers, farmers and some industries faced high electricity prices while energy-intensive industries were exempt, a disparity that attracts much criticism. The project involves dismantling nuclear power plants, which leads to increasing use of coal or natural gas. Another challenge is to keep investments on track. This article presents the topic from its historical development and shows that German energy strategy surpasses moral and economic concerns. Beyond economics and energy security, it is a broader plan to place the country in the vanguard transition to green capitalism.
\end{abstract}

Keywords: Energiewende; Germany; Renewable Energy; Green Capitalism.

\section{Resumo}

A Alemanha desenvolveu uma estratégia ambiciosa para aumentar a participação de fontes renováveis na matriz energética e viabilizar a transição para um paradigma verde. Conhecida como Energiewende, essa política implicou profundas transformações estruturais no sistema energético. A participação da população e de pequenos empreendedores destaca-se entre as suas particularidades. O Estado conduz o projeto, mediando interesses divergentes entre

1 Programa de Pós-Graduação em Relações Internacionais San Tiago Dantas (Unesp, Unicamp, PUC-SP); Instituto Nacional de Ciência e Tecnologia para Estudos sobre os Estados Unidos (INCT-Ineu), ambos em São Paulo/SP, Brasil. E-mail: reissolange@gmail.com

Artigo submetido em 20/02/2017 e aprovado em 20/09/2017. 
agentes sociais e econômicos. O desafio é manter o consenso social apesar dos custos desiguais. Consumidores individuais, agricultores e algumas indústrias sofrem aumento no preço da eletricidade, enquanto o setor industrial intensivo em energia recebe isenções, situação que gera muitas críticas. O projeto envolve o fechamento do parque nuclear, o que leva ao aumento no uso de carvão ou gás. Outro desafio é manter os investimentos necessários. $\mathrm{O}$ artigo apresenta o tema a partir de seu desenvolvimento histórico, indicando que a estratégia ultrapassa preocupações morais e econômicas atuais. Para além da economia e da segurança energética, o projeto posiciona o país na vanguarda da transição para o capitalismo verde.

Palavras-chave: Energiewende; Alemanha; Energia Renovável; Capitalismo Verde.

\section{Introduction}

Will an industrialized country that consumes a substantial amount of energy and still has pretty high emissions manage to achieve the ambitious goals without jeopardizing the security of supply, triggering a massive increase in energy prices and, above all, scaring off power-intensive branches of industry? (DEUTSCHE BANK, 2012, p. 2)

At some point in one Deutsche Bank report, these questions arise about the viability of the German energy policy called Energiewende. Similar doubts foster debates in various academic, political, and communication spheres. At the heart of the issue lies the effectiveness of the German strategy to achieve high rates of electricity from renewable sources and to reduce greenhouse gas emissions, while eliminating the use of nuclear energy.

Energiewende comprises a set of legislation, incentives and investments to increase the share of renewable sources in electricity generation and to combat climate change. Its design implies costs and transformations that require constant engagement of economic and social sectors.

Although the government is the architect of this transformation, the horizontality of the operational process involves individuals and city councils, as well as small and large entrepreneurs. The strategy started before German Reunification, surviving governments of different ideological orientations. The environmental motivations coincide with those of the European Union (EU), but the project reflects the German conception that energy and industrial policy go side by side.

Given the growing integration of the German market with the European energy infrastructure, Energiewende impacts neighboring countries. Some of them 
see German energy policy with good anticipation; other nations perceive it as a catalyst for regional asymmetries. According to some critics, with the excuse for reducing domestic and regional dependence on external fossil resources, Germany plans to lead the common market by becoming a major exporter of secondary energy and leveraging markets for its green technology industry.

With regard to external dependence, the option to end nuclear energy implies more gas consumption in the short and medium term. Good for Russia, bad for transatlantic relations, significant for international politics.

The article summarizes its historical and regulatory points, and indicates some possible effects for Germany's foreign energy policy. It highlights the role of the state as a transformative agent towards a new model of industrialization in the $21^{\text {st }}$ Century. As the last section of this paper shows, a similar sort of Schumpeterian green transition is being adapted and advanced by emerging countries such as China as a way to sustain its enormous economic needs.

\section{History}

The Energiewende has ambitious goals and implies structural and regulatory transformations in the way that energy is generated, subsidized, distributed and remunerated.

Figure 1: Goals and Results

\begin{tabular}{|c|c|c|c|c|c|}
\hline Emission reduction goals & $\mathbf{2 0 2 0}$ & $\mathbf{2 0 3 0}$ & $\mathbf{2 0 4 0}$ & $\mathbf{2 0 5 0}$ & Situation in 2014 \\
\hline $\begin{array}{c}\text { Reduction of greenhouse gas } \\
\text { emission (year basis 1990) }\end{array}$ & $-40 \%$ & $-55 \%$ & $-70 \%$ & $-80 \%$ & $-26,4 \%$ \\
\hline $\begin{array}{c}\text { Renewable sources in total } \\
\text { energy consumption }\end{array}$ & $+18 \%$ & $+30 \%$ & $+45 \%$ & $+60 \%$ & $+12,4 \%(* 2013)$ \\
\hline $\begin{array}{c}\text { Renewable sources in total } \\
\text { power consumption }\end{array}$ & - & $+40 \%$ & $+55 \%$ & $+80 \%$ & $+27,3 \%$ \\
\hline $\begin{array}{c}\text { Reduction in primary energy } \\
\text { consumption (year basis 2008) }\end{array}$ & $-20 \%$ & - & - & $-50 \%$ & $-9,1 \%$ \\
\hline $\begin{array}{c}\text { Reduction in power consumption } \\
\text { (year base 2008) }\end{array}$ & $-10 \%$ & - & - & $-25 \%$ & $-4,8 \%$ \\
\hline
\end{tabular}

Source: AGORA, 2015; BUCHAN, 2012. 
The project stands on four pillars: (a) public incentives for renewable energy as primary source for electricity; (b) infrastructure modernization, (c) decentralization of supply and consumer autonomy; (d) closing of the nuclear industry. Structured around the increase of wind and solar energy, it proposes to eliminate the use of nuclear power plants until 2022 and drastically reduce the percentage of coal in the energy matrix until 2050.

German government took the first steps in that direction in the 1970s, when oil shocks took place and environmental protection ideas gained track. As many other countries did, Germany also sought to diversify its oil suppliers beyond the Middle East. That led to the intensification of its relations with the Soviet Union in the wake of the Ostpolitik and the gradual incorporation of "red gas" (Russian) into West Germany energy matrix (HÖGSELIUS, 2013).

At the same time, it sought to increase energy security through renewable sources and the creation of public agencies for planning and implementing clean energy policies. Although the term "energy security" comprises various definitions, from geopolitical to economical sense, this paper consider it as low vulnerability of vital energy systems (CHERPA; JEWELL, 2014).

Investments in nuclear power grew at that time too, but the resistance of the population represented a constant barrier to the nuclear sector. Anti-nuclear feelings since the 1970s partly explain why Energiewende is welcome by civil society today notwithstanding the economic and social costs of the process.

The concept of "energy transition" was borrowed from the book "EnergieWende: Wachstum und Wohlstand ohne Erdol und Uran" about growth and well-being without oil and uranium. The book argued that the fundamental and radical change in the energy policy of the Federal Republic of Germany (and of the industrialized countries in general) has become indispensable" (KRAUSE, BOSSEL, REISSMANN, 1980, p. 13).

The Green Party's (Die Grünen) first election for Federal Parliament in 1983 and the Chernobyl nuclear accident in Ukraine three years later stimulated the establishment of the Federal Ministry for the Environment, Nature Conservation, Construction and Nuclear Safety (Bundesministerium für Umwelt, Naturshutz, Bau and Reaktorsicherheit), raising the issue in the hierarchy of the institutional agenda.

Since then, a set of initiatives at federal, state and municipal levels have redesigned the rules of the electric sector. Those actions included fostering production of clean energy at residences and the dismantling of operational 
monopolies. The issue gained urgency during German Reunification in 1990 as the industrial and energy industries in former East Germany relied on energy intensive Soviet model.

On a regional level, the adhesion to the European Energy Charter in 1994 stimulated market liberalization. It also helped dismantling large conglomerates of electricity in the European bloc, prohibiting suppliers from participating in power distribution. The model adopted in Germany opened doors for wind and solar generators that still lacked competitiveness. By the time of Kyoto Protocol in 1997, the country committed itself to more ambitious targets than the EU. While the bloc proposed to reduce pollutant emissions by $8 \%$ over 1990 levels, Germany made the individual commitment of $21 \%$. (EUROPEAN COMISSION, 2017).

It is important to note that Chancellor Angela Merkel was in charge of the Ministry of Environment during Kyoto negotiations. The fact counts as an indication that the development of Energiewende extrapolates ideological or partisan divisions. Therefore it could be viewed as raison d'état and national interest. The environmental policy of conservative coalitions does not differ conceptually from the leftist proposals despite the differences regarding the nuclear issue and the extent of the state role (HAKE et. al, 2015).

In the United States, for instance, the cleavage between Democrats and Republicans persists with regard to the adoption of climate policies, as the latter tend to prevent legislation on environmental protection (FERREIRA; VIGEVANI, FERREIRA, 2012).

In 2002, the first fully left-wing coalition in West Germany, by Sozialdemokratische Partei Deutschlands (SPD) and the Bündnis 90/Die Grünen, also known as RedGreen Coalition, approved the closure of the national nuclear plants (Atomaustieg) by 2022. Although more motivated by the risk of accidents and toxic waste effects, and less by the level of pollution inherent in uranium mining, the socialist proposal placed Germany at the forefront of a clean energy system with less threat to human security.

Continuing the paradigm shift, the conservative coalition by the CDU/ CSU-Fraktion and the liberal Freie Demokratische Partei (FDP) adopted the “Energiekonzept” (DIE BUNDESREGIERUNG, 2010) in 2010. The document focused on making Germany one of the world most energy-efficient and climatefriendly economies, but the path should be gradual and market-oriented. The plan announced the postponement, for up to 14 years, of the closure of nuclear power plants, as atomic technology should serve as a bridge in the energy transition. 
The setback, called by the media as "Exit out of Exit" (DIE ZEIT, 2011), reflected the pressure of interest groups, notably the fossil segment, as well as the economic crisis and the austerity in the European bloc. While defending a non-fossil pattern, Merkel had always opposed the dismantling of the nuclear industry (SOKOL, 2005).

However, the return of nuclear policy did not avenge. Popular demonstrations, criticism by left opposition and the accident at the Japanese Fukushima plant in 2011 forced the government to rewind and shut down eight nuclear power stations that run with reactors built before 1980. The number of nuclear plants closed at once was equivalent to more than 50 percent of the entire national installations (DEUTSCHE WELLE, 2011). The Parliament approved the reversal by $80 \%$ of votes. One of the rejections votes came from Die Linke, the far-left party that advocated for an even faster dismantling (APPUNN, 2015). Since then, Energiewende has gained solidity and controversy.

\section{Development}

Wind and solar power are the central elements of the transformation, which increased the share of renewables in electricity generation from $4 \%$ in 1990 to $27 \%$ in 2014 (NOW, 2014, p. 5). Due to initial costs and intermittency that typically characterized these two industries at that time, the challenge was to innovate in technology and adopt regulations that would make the two sources more reliable and competitive. High costs, coupled with operational instability, would reduce public support and affect the export sector.

The solution required state intervention to ensure, through legislation, the priority of alternative sources in the distribution network despite the lack of competitiveness of renewable energy plants in its initial phase. In this sense, Energiewende exemplifies German ordoliberalism.

The central tenet of ordoliberalism is that governments should regulate markets in such a way that market outcome approximates the theoretical outcome in a perfectly competitive market (in which none of the actors are able to influence the price of goods and services)”. (DULLIEN, GUÉROT, 2012, p. 2).

The first mechanism applied was the feed-in tariff (FiT) laws of 1991, which established a tariff system for the protection of the renewable segment. The FiT 
guaranteed a fixed remuneration for 20 years and priority for green sources in the network of national power distribution. This regulation is a public incentive with great support from the political class (LAIRD, STEFES, 2009, p. 2622).

As energy from renewable sources may be more expensive in its early beginning, the legislation allowed the four major distributors (Eon, RWE, EnBW and Vattenfall) to buy expensive energy from green operators and resell it in the European Energy Exchange, which trades electricity, natural gas, permits for $\mathrm{CO} 2$ emissions and coal through spot and derivative contracts. Final consumers such as residences, commerce, services and non-energy intensive industries pay for the difference between wholesale and stock market prices. That marks the first imbalance in the distribution of costs, an inequality that fuels much criticism.

Other sectors that receive additional tariff exemptions are energy-intensive industries such as chemical and metallurgical, and factories that generate their own energy. These exceptions preserve the competitiveness of the giants, burdening small and medium-sized industries, residences, and commerce.

FiT tariffs were questioned in the European Court of Justice as a sort of subsidy and, thus, a violation of free trade rules. In 2001, the Court dismissed the claims as unfounded arguing that EU member states could oblige electricity distributors to buy clean energy at a price above market value as long as they repassed the costs to consumers. This interpretation also took into account the importance of renewable energy for the environment and the reduction of greenhouse gases that cause climate change (EUROPEAN COURT, 2001). Currently, more than two-thirds of European countries adopt some form of FiT (LAIRD, STEFES, 2009, p. 2244).

In July 2016, German Parliament approved reforms, maintaining the fixed remuneration system only for small producers, such as residences and commercial business that had installed solar panels on their roofs. Medium and large providers of clean energy must follow the market prices. Those reforms serve the interests of traditional generators and non-tariff-free industries; on the other hand, by maintaining fixed remuneration mechanism for smaller producers, the government aims to guarantee operational and political support from the population. The economic sustainability of the Energiewende will be under test from now on as the visible hand of the state reduces its intervention.

The project receives increasing support from the population, although this varies according to economy mood: more than $90 \%$ support Energiewende (WETTENGEL, 2016). The popular participation is not restricted to ideas and voting, as residential consumers bear much of the extra costs. By 2013, households 
contributed $€ 8.3$ billion of the total $€ 23.6$ billion spent on electricity, although residential consumption was only a quarter of the total (NOW, 2014, p. 31). The same type of support is common among politicians, as $85 \%$ of Parliament voted in favor of related legislations (NOW, 2014, p. 9).

Decentralization is what favors German energy policy in comparison with similar experiences in other countries. It is possible to say that Energiewende is the most participative process of energy transition in a capitalist state, whose macro objective is to develop a policy based on environmental safer provision of energy, self-sufficiency and future competitiveness. It means energy security without geopolitical constraints.

One measure towards decentralization was to reduce monopolies in the energy generation and distribution sectors. Four energy giants - Eon, RWE, ENBH and Vatenfall - control the thermoelectric sector but split the renewable segment with industries, small businesses, cooperatives, project developers, farms and citizens. In 2013, small producers were responsible for $46 \%$ of renewable energy installed capacity, compared to $13 \%$ of large operators, and $41 \%$ of strategic institutions and investors (BORSCHERT, 2015).

Another relevant aspect is the decentralization achieved by placing the local distribution systems under the supervision of city councils and due to large community involvement in planning and fundraising. Individuals can invest from $€ 100$ to $€ 500$ in green energy generation projects, which promotes popular engagement in the defense of industry interests (BUCHAN, 2012, p. 10).

According to Quitzow et al. (2016), the development of state-of-the-art technology for renewable energies finds its roots in communitarian projects and in the economic model based on small and medium-sized businesses. Approximately $99 \%$ of the general enterprises in the country fit into the so-called Mittelstand, responsible for $55 \%$ of GDP (BUNDESMINISTERIUM FÜR WIRTSCHAFT UND ENERGIE, 2014).

Over time the green policy has been battling fossil-fuelled industries, politicians linked to traditional energy inside and outside the country, part of the liberal media and even radical environmentalist. For a renowned British magazine, Energiewende meant expensive energy and increased carbon emissions due to the replacement of nuclear by coal (THE ECONOMIST, 2014). "Although the share of renewable energy in the German grid has increased since the year 2000, CO2 emissions have also risen since 2009. Is Germany trapped in the Energy Transition Paradox?" (NOW, 2014). 
Virulent criticisms also come from the progressive side. Boisert (2013) acknowledges that Germany was pioneer, but he sees its energy leadership as one of today's most demoralizing ironies.

The Energiewende is not the swift, bold advance that greens imagine but a slow, timid, and inadequate response to the crisis of climate change. It represents a failure of nerve, a failure of imagination, and a failure of arithmetic. It is visibly failing now, and if it succeeds in all its stated goals it will still fail. It is failing for a simple reason: the environmental movement, whose signal triumph is its influence over energy policy, has rejected nuclear power-the best source of clean energy we have”. (BOISERT, 2013).

The figure below indicates that the emissions indeed increased between 2009 and 2010, which might having be caused by growth in oil (and coal) consumption as oil price fell during those years. Again between 2011 and 2013, what maybe reflected the sudden shutdown of some nuclear power plants.

Figure 2: Greenhouse Gas Emissions in Germany

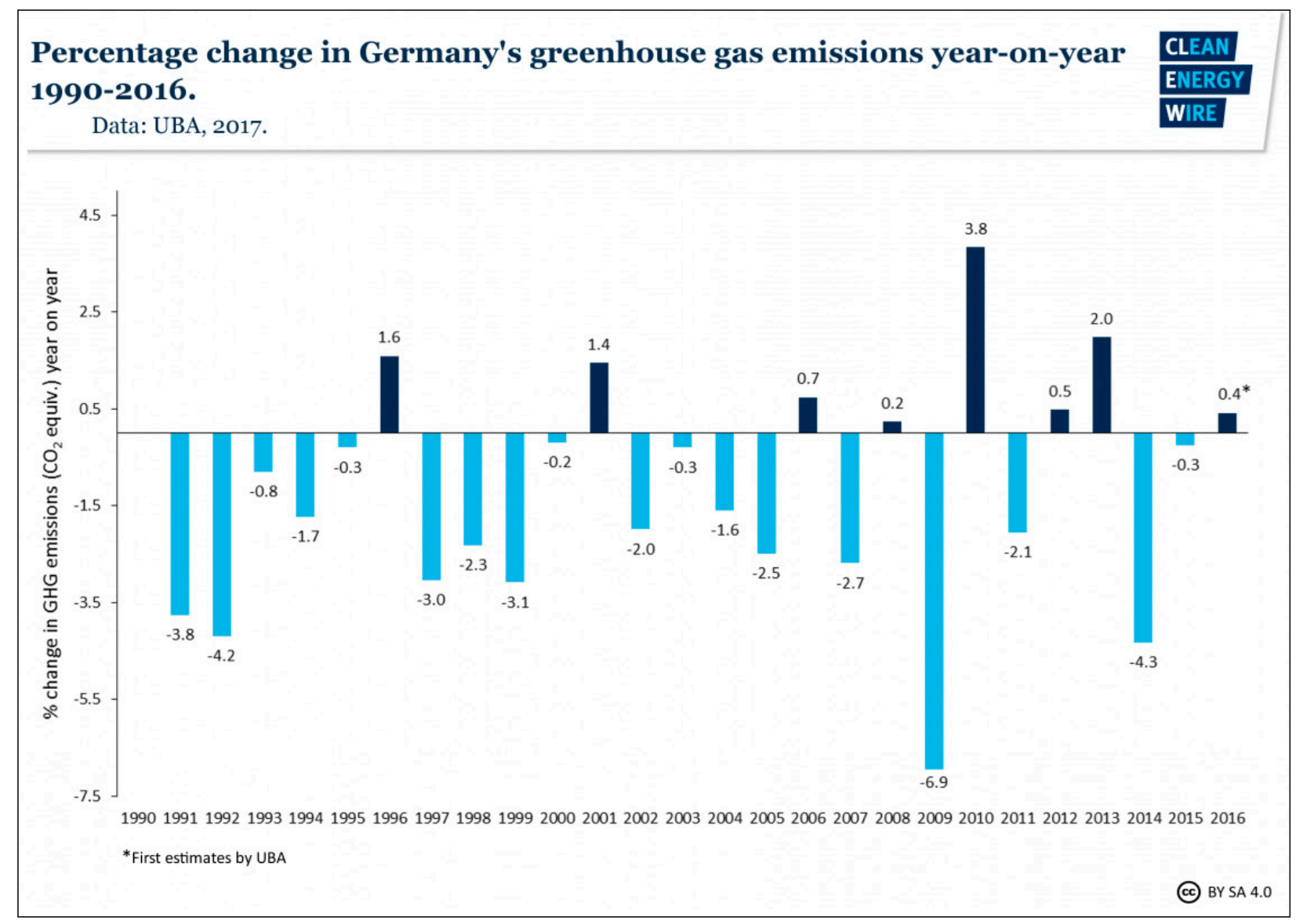

Fonte: CLEAN ENERGY WIRE, 2017 
The graphic information above reveals that 2016 was a negative year for German emission reduction target. Harsh weather, growing economy and increase in population - about 1 million refugees were allowed to live in the country in 2015 - could explain the downturn (WETTENGEL, 2016).

German energy policy has indeed many challenges. However, after more than 20 years of the resilient "Energie Konzept", the mixing system of fossil fuels and renewable energy has proven its maturation: today Germany has the world's most reliable electricity generation (BALL, 2017).

Many challenges need to be overcome, such as the distances between the wind farms concentrated in the north of the country and the urban and industrial centers in the south. The alternative is to increase and modernize the transmission lines. It happens that the modernization and the ideal functioning of the network depend on heavy and continuous investments as part of a long-term political and economic strategy.

Vaclav Smil argues that energy infrastructure is one of the most expensive investments in the world, and that the longevity and inertia of many energy enterprises make it impossible for any complex national system to reconfigure itself in three to four decades (SMIL, 2015). Quite a pessimistic view! Notwithstanding many obstacles, the prospects are shiny for German energy policy.

The direction of change is clear. At every stage since the 1970s, when the antinuclear movement saw the first stirrings of what would become the Energiewende, its ambitions have been dismissed as impossible to deliver. At every stage that has proved wrong. (...) The Energiewende has altered the energy mix in Germany and broken the old business model of the power-generating utilities. But there is much more to come (BUTLER, 2016).

\section{Energy foreign relations}

Sustainability alone does not explain such a radical policy. The foundations of Energiewende were also established in the quest for less energy dependence, more economic growth and in the search for the state of the art technology (QUITZOW et al., 2016, p. 2). With $61.4 \%$ dependence on foreign resources, energy policy means foreign policy for Germany. Therefore, the key word behind it is energy security in the sense of low vulnerability of any kind. 
Figure 3: Domestic production and imports

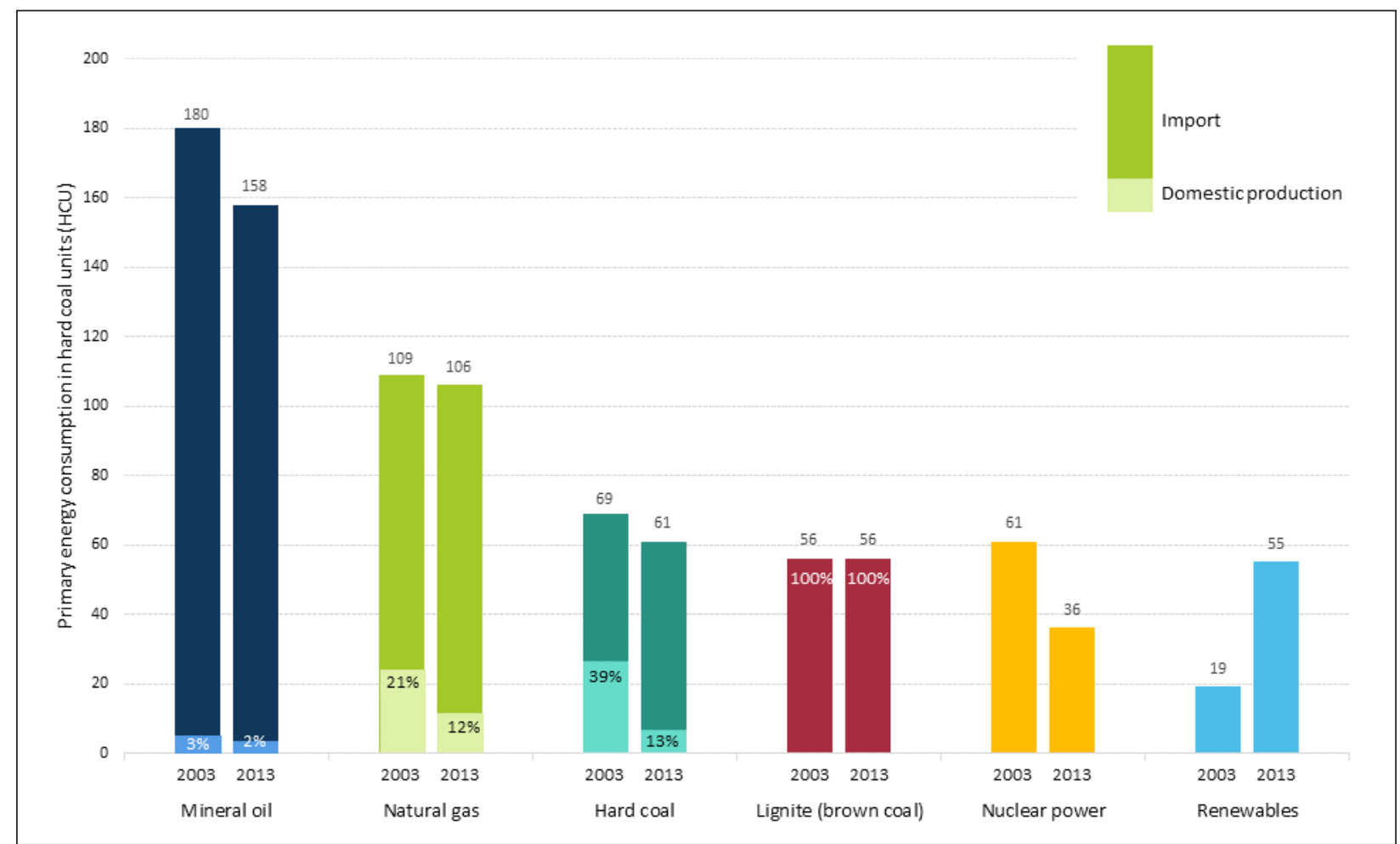

Source: WETTENGEL, 2016.

As gas in Germany is often used for heating, and not as much for electricity, Energiewende shall not affect imports in the medium term. Imported gas comes through western and eastern pipelines, with strong geopolitical implications in the second case.

The option for shutting down the nuclear power plants and the majority of the mining industries by 2050 should underscore the importance of Russian gas. Broadly speaking, Energiewende deepens relations with Russia for now and loosen them in the long term.

Energy security, environmental concerns and economic growth explain Germany's interest in keeping Energiewende and in becoming a major energy actor in its region as well as a green technology exporter.

One example of this effort is the creation of the Energy Export Initiative. Commissioned by the federal government since 2002, the program helps German companies to reach markets abroad.

To achieve these goals the country cannot depend on foreign fossil fuels anymore. Russian has been a reliable partner so far, but a large volume of oil comes from political instable areas such as the Middle East. Germany has coal reserves but the dirty mineral must be left behind if environmental health and climate change are considered. 
Therefore, part of the strategy is to become itself a reliable provider of electricity. In the first semester of 2017, Germany exported $11 \%$ of its electricity production to Central and East European countries (MORRIS, 2017).

Eventually, countries with low-cost renewable energy production will absorb regional green market shares and even compete with German industries in Germany. One-step in this direction is the EEG 2016, which allows neighbors states to supply renewable energy to Germany as long as they participate competitively in the auctions adopted with the reforms.

Maintaining and broadening the green shift in the next decades is crucial to Germany economy and overall security. This road has brought (and will keep bringing) opportunities for cooperation with countries such as China, which has pursued a similar energy transformation in the last years. This scenario, as shown in the next section, could also mean fierce competition in the next phase of industrialization.

Besides the economic gains indicated in this paper, Germany also enjoys the benefits of green energy as soft power. Apart from being an active player in all UN climate change negotiations so far, the country has expanded global governance in renewables.

One year after the first oil shock, the secretary of State of the United States, Henry Kissinger, proposed an international institution to organize and defend the interests of oil consuming countries. The plead led to the creation of the International Energy Agency to increase predictability in order to avoid geopolitical constraints and market disruptions. Considering its focus on finite resources and rather negligent concern with renewables, the organization could also be named "International Fossil Agency".

A similar institution for green energy was not created until Germany tried to test its soft power by convincing other countries that Energiewende could be replicated worldwide.

A remarkable initiative to develop renewable energy abroad was the creation of the International Renewable Energy Agency (IRENA), an international organization whose existence is the result of German efforts at intergovernmental level. In 2007, while using its presidency on the EU Council and the G8, Germany started to work for the creation of an organism outside the UN, where powerful forces blocked any proposal of that kind. 
While Germany successfully promoted a 20\% target for the expansion of RE in the EU, the 2006 and 2007 sessions of the UN CSD proved to be a serious blowback for the German strategy to promote RE on a global scale. Instead of approving the desired time-bound targets for a global share of RE, the session resulted without any agreement. While already an increasing number of G77 supported RE, the Gulf States let by Saudi Arabia blocked a decision underlining the importance of RE. After this experience, the Environment Ministry decided to change its strategy. Instead of trying to push RE within the $\mathrm{UN}$, it decided to work on the creation of a new international organization for RE outside of the UN framework, uniting like-minded countries. Under the aegis of Karsten Sach, Deputy Director-General for International Cooperation, the Environment Ministry mobilized political support within the German Government. Together with the Development Ministry and the Ministry of Foreign Affairs, it started an international campaign for IRENA's creation (ROHERKASTEN; WESTPHAL, 2013).

IRENA was finally developed in 2008 without the support of many countries, including the emerging nations such as China, India and Brazil. The first two signed to it later, but Brazil still resists membership as IRENA focus on solar and wind, while the country favors hydropower and biofuels. Today, IRENA has 150 members and 27 are under process of becoming members.

Reproducing German green transition in other countries is definitely a challenge. Low credit, underknowledge and the lack of an appropriate domestic political system might block any chance in many nations. Who knows?

Specialists like Vaclav Smil are deeply pessimistic with renewable capacity to adequately scale in order to satisfy energy demand in our modern societies.

I like renewables, but they move slowly. There's an inherent inertia, a slowness in energy transitions. It would be easier if we were still consuming 66,615 kilowatt-hours per capita, as in 1950. But in 1950 few people had air-conditioning. We're a society that demands electricity $24 / 7$. This is very difficult with sun and wind.Look at Germany, where they heavily subsidize renewable energy. When there's no wind or sun, they boost up their old coalfired power plants. The result: Germany has massively increased coal imports from the US, and German greenhouse gas emissions have been increasing, from 917 million metric tons in 2011 to 931 million in 2012, because they're burning American coal. It’s totally zany! (SMIL, 2013).

As the next section points out, more optimistic views show otherwise. 


\section{Green industrial transition}

Beyond regional gains, Energiewende might place Germany in a broader competitive condition if global climate governance advances. A comprehensive agreement as intended in COP 21 (Paris Agreement) would raise fossil costs, favoring German industries to the detriment of many competitors in industrialized countries. Both solar and wind industries have a high initial capital investment, but the marginal cost approaches zero after depreciation.

As one of the global leaders in green technology, the country has achieved this position by making huge R\&D investments (private and public) in renewable energy. Germany has strengthened its capacity to export products and services for manufacturing solar and wind devices, trying to turn itself from a fossil fuels dwarf into a green energy power.

Political studies on renewable energy focus the economic losses and gains for different sectors and on how partisan agendas reflect the preferences of voters and interest groups. In other words, (domestic) politics guides the discussion. Normally absent from international relations analysis - except in debates about climate governance - the issue is seldom observed from an international power politics perspective.

A transition to green energy paradigm requires attention to the dynamics of international politics on multiple levels such as economic, finance, trade, technology, law, environment, human rights, and many others. Besides, one must not forget the tight industrial competition among countries and on how energy security (cheap, reliable and abundant) may define winners and losers.

For decades, the definition of security energy prioritized fossil fuels and its implications for international security and world stability. After so many resource wars in last and current centuries, few would disagree that - even in times of abundance - fossil fuels are potential conflict-triggers. Mainly due to unequal geographic distribution of resources that brings nations to geopolitical disputes or to permanent dependence on highly politicized market.

German trajectory finds cooperation and competition with other industrial powers such as China, which is inserted in the select group of countries that seek to promote profound changes in energy systems. In 2015, China led global investments in renewable energy, followed by the United States, and far ahead of Germany and Brazil, respectively in sixth and seventh position (FRANKFURT SCHOOL-UNEP CENTER / BNEF, 2016). 
Among the ten largest investors in this ranking, Brazil and Germany were the only ones that reduced investments in 2015 compared to the prior year. In the Brazilian case, the economic and political crisis that has been affecting the country since then explain the fall. As for Germany, the reduction could be related to uncertainties regarding the future of FiT, a proof that domestic system may not be enough mature to be guided only by the invisible hand of the market.

In the United States, renewable energy sector gained emphasis during Obama administration. As the democrat President expressed in the State of the Union Address of 2010, "the nation leading the clean energy economy will command the global economy" suggesting that the United States should empower itself to the role.

Despite the roller coaster of legislations that allowed and withdrawn incentives for renewables after 2013, the U.S. the country invested $\$ 44$ billion in clean energy in 2015. The current scenario, however, discourages investments as President Donald Trump promises to increase production of non-renewable sources and to create jobs in the fossil sector.

As Republicans control both Houses in Congress after Trump's election, it will not be difficult for the President to deliver on campaign promises by discouraging growth in renewable energy sector. If this perspective is confirmed, the U.S. will step back from what Matthews (2017) calls the "green shift".

In the author's view, green transition means the destruction of an energy system based on the exploitation of fossil resources, characterized by geographic concentration, high production costs and geopolitical risks. On the other hand, the manufacturing of renewable energy is justified by the reduction of costs, geographic decentralization (energy produced anywhere and at any time) and the absence of geopolitical threats. "The green shift is the latest episode of this process of Schumpeterian industrial evolution", he argues.

It encompasses more than energy policies on moral grounds. The main purpose of the green shift is to achieve energy security and economic leadership in the 21st century, when manufacturing costs will be the determining factor in industrial competition.

A paradox of our times is that, while libertarian ideas of small government gain track, a country with overwhelming state presence on economic activity leads investments in renewables. I refer to China, which in 2015 invested $36 \%$ of the global total, an amount equivalent to US\$ 102 billion.

The cooperation in trade and technology between Germany and China was crucial for transforming the Chinese energy system. By acquiring German products 
and services, China was able to start its own green transition and to become the world leader in manufacturing of solar and wind energy.

Actions taken by the United States and the European Union against China in the World Trade Organization - for alleged subsidies and dumping practices in Chinese solar and wind industries - indicates the extension of the competition. Beijing has tried to avoid those complaints by relocating part of its premises in other countries.

Despite its divergent political system, are countries such as Germany and China betting on clean energy to overcome environmental constraints, but also as a strategy for a new stage of industrial capitalism? Are both nations investing in the energy innovation that will sustain Kondratieff's sixth wave (MATTHEWS, 2012), and reorganizing the productive base of the next world system leadership (ARRIGHI, 1995)?

Matthews (2016) argues that future industrial leadership will only be achieved through green shift.

Some advantages of renewable energy are not at all obvious and need to be made explicit. Fundamentally, they are scalable and can be built in a modular way - a solar panel, 100 solar panels, 1000 solar panels. As they are replicated in this way, their powers continue to rise without cutting efficiency. This cannot be said of nuclear reactors, which have an optimum operational size - below or above which the plant is underestimated. Furthermore, as they scale, they do not present greater and greater risks. Instead, they are relatively benign technologies with no serious risks... More importantly, the superiority of conventional renewable energies lies in their cost reduction trends, which are linked to the fact that they are always manufacturing and production products Where economies of scale actually play a role. This means that they offer true energy security, insofar as manufacturing can in principle be carried out anywhere (MATTHEWS, 2016).

The author points out, however, that the green transformation is being mainly driven by emerging countries such as China and India. Energy policies of these states do not reflect a sense of morality, but "strategies of national development of priorities". The rationality behind this strategy has less to do with public policies, corporate interests or demand, and more with cost reduction that green energy systems bring to power sector and to agricultural and industrial activities.

In a scenario of intense industrial competition that shall mark the current century, the cost factor will be decisive for the industrialization and deindustrialization 
of countries. Emerging nations in the East face the limits of growth, as fossil resources do not increase in the scale needed for the economic development of gigantic countries such as India and China. In addition, resource exploitation requires involvement in geopolitical issues that add costs of a different nature, such as military security.

In "Greening of Capitalism: How Asia is driving the next great transformation" Matthews (2015) says that the third phase of Industrialization will determine whether the industrial way of life will be able to continue providing (unequally) wealth and well-being without destroying the planet. The answer does not lie in moral principles of environmentalism or market opportunism.

A major structural transformation of capitalism requires state direction. Considering the characteristics of Chinese political system, despite its authoritarianism, China presents itself as the country with the potential to lead the great transformation.

Capitalism is the vibrant technical-economic system that allows such industrial dynamics. There is really no secret about why China is seeking abundance of energy and resource security through its highly targeted industrial strategies. The only mystery is why the West allows it to win in the competition unleashed in the international political economy. Changing the policy emphasis so that it engages directly with the economy through industrial strategy and changing the rationality of renewable energy to building energy security through its manufacturing would be an advance to restore some equilibrium (MATTHEWS, 2015).

Those arguments are extensively detailed in his recent book "Global Green Shift: When Ceres meets Gaia”. Renewable energy and information technology for green energy system is ate the center of what Schumpeter would call a sixth wave of creative destruction. It is not only a matter of substituting one technology for another, as neoclassical economists would say; it is about reviewing the industrial paradigm of our civilization (MATTHEWS, 2017).

\section{Conclusion}

The article explained German energy policy, known as Energiewende, from its historical perspective and pioneering. Some aspects differentiate German strategy from other examples in Europe and in the world. 
One factor is the active role of the state in planning and implementing legislations, infrastructure and incentives. The project survived successive government changes throughout the years, proving that its rationality is beyond partisanship.

Other factor is the participation of social actors, such as individuals, farmers, cooperatives and small entrepreneurs. Besides paying for higher electricity, those stakeholders get direct involvement in green initiative either by installing small solar and wind generators in its properties or by financing many of the projects.

Energiewende is also unique for its commitment to dismantle all nuclear plants until 2022, an ambitious target that faces resistance of many economic groups and implies more consumption of gas in the short term. Taking into account Germany's poverty in indigenous gas production, the replacement of nuclear by gas increases its dependence on Russia, a gesture that triggers a lot of criticism nationally and internationally.

Notwithstanding many barriers, Energiewende turned Germany from an energy dwarf into a regional power supplier. The new condition and its prospects has explained some changes in Germany's foreign policy toward East Europe recently, as in the case of Ukraine.

Maintaining the plan requires investments in modernization, infrastructure and adequate regulations, a challenge that faces constant skepticism among much of its opponents.

However, by implementing a profound energy transition Germany could place itself among a select group of countries that will lead a new phase of industrial capitalism. A pursue of "green shift" not on moral or environmental grounds but as a quest for economic and political power.

\section{Bibliography}

AGORA. Understanding the Energiewende FAQ on the ongoing transition of the German power system Background. October 2015. Available in: https://www.agora-energiewende. de/fileadmin/Projekte/2015/Understanding_the_EW/Agora_Understanding_the_ Energiewende.pdf. Accessed in: 02.02.2017

APPUNN, Kerstine. The history behind Germany's nuclear phase-out. Clean Energy Wire. 24 Jul 2015. Available in: https://www.cleanenergywire.org/factsheets/historybehind-germanys-nuclear-phase-out. Accessed in: 01.04.2016. 
ARRIGHI, Giovanni. O Longo Século XX: dinheiro, poder e as origens de nosso tempo. Rio de Janeiro: Editora Unesp, 1995.

BALL, J.. Germany’s High-Priced Energy Revolution. Fortune. 2017. Available in: http:// fortune.com/2017/03/14/germany-renewable-clean-energy-solar/. Acesso em?

BOISERT, Will. Green Energy Bust in Germany. Dissent. Summer, 2013. Available in: https://www.dissentmagazine.org/article/green-energy-bust-in-germany. Accessed in: 07.02.2017.

BORSCHERT, Lars. Citizens' participation in the Energiewende. Clean Energy Wire. 10 Mar. 2015. Available in: https://www.cleanenergywire.org/factsheets/citizensparticipation-energiewende. Accessed in: 14.08.2016.

BUTLER, Nick. The power behind the shift to renewable energy in Germany. Financial Times. November 7, 2016. Available in: https://www.ft.com/content/31474df4-a2ab11e6-82c3-4351ce86813f. Accessed in: 09.02.2016.

BUCHAN, David. The Energiewende: Germany's gamble. The Oxford Institute for Energy Studies. SP 26. June, 2012. Available in: https://www.oxfordenergy.org/wpcms/ wp-content/uploads/2012/06/SP-261.pdf. Accessed in: 21.05. 2016.

BUNDESMINISTERIUM FÜR WIRTSCHAFT UND ENERGIE. German Mittelstand: Motor der Deustchen Wissenschaft. 2014.

CHERPA, A.; JEWELL, J.. The concept of energy security: Beyond the four As. Energy Policy. Volume 75, December 2014, Pages 415-421. Available in: https://www. sciencedirect.com/science/article/pii/S0301421514004960.

CLEAN ENERGY WIRE. Germany’s greenhouse gas emissions and climate targets. 2017. Available in:: https://www.cleanenergywire.org/factsheets/germanys-greenhousegas-emissions-and-climate-targets. Acesso em?

DEUTSCHE BANK. Germany's energy turnaround: Challenging for municipalities and municipal utilities.. DB Research. September 17, 2012. Available in: https://www. db.com/cr/en/docs/Germanysenergyturnaround.pdf. Accessed in: 06.08.2016

DEUTSCHE WELLE. German cabinet approves 2022 nuclear shutdown. Deutsche Welle. Available in: http://www.dw.com/en/german-cabinet-approves-2022-nuclearshutdown/a-15134028. Accessed in: 22.05.2016.

DIE BUNDESREGIERUNG. Energiekonzept für eine umweltschonende, zuverlässige und bezahlbare Energieversorgung. Bundesregierung. 28.10.2010. Available in: https://www.bundesregierung.de/ContentArchiv/DE/Archiv17/_Anlagen/2012/02/ energiekonzept-final.html. Accessed in: 08.08.2016.

DIE ZEIT. Atompolitik: Austieg aus dem Austieg aus dem... Die Zeit. 24. März 2011. Nr. 13/2011. Available in: http://www.zeit.de/2011/13/Regierungsvertrauen. Accessed in: 05.08.2016. 
DULLIEN, Sebastian; GUÉR, Ulrike. The long shadow of ordoliberalism: Germany's approach to the euro crisis. European Council on Foreign Relations. ECRF/49. February 2012.

EUROPEAN COMISSION. Kyoto 1st commitment period (2008-12). 2017. Available in: https://ec.europa.eu/clima/policies/strategies/progress/kyoto_1_en. Accessed in: 02.02.2017.

EUROPEAN COURT. Judgment of the court of 13 march 2001. Available in: http://eurlex.europa.eu/legal-content/EN/TXT/PDF/?uri = CELEX:61998CJ0379\&from = EN

FERREIRA, Solange Reis; FERREIRA, Kelly and VIGEVANI, Tullo. An overview of domestic aspects in US climate policy. Rev. bras. polit. int. [online]. ISSN 19833121., vol.55, n.spe, 2012, pp. 88-103. Available in: http://dx.doi.org/10.1590/ S0034-73292012000300006.

FRANKFURT SCHOOL-UNEP CENTRE/BNEF. Global Trends in Renewable Energy Investment 2016. Available in: http://www.fs-unep-centre.org (Frankfurt am Main). Accessed in: 31.08.2016.

HAKE, J.f. et al. The German Energiewende - History and Status Quo. Forschungszentrum Jülich, Institute of Energy and Climate Research - Systems Analysis and Technology Evaluation (IEK-STE), D-52425 2015, Jülich, Germany. Available in: http://www.fzjuelich.de/SharedDocs/Downloads/IEK/IEK-STE/DE/Publikationen/preprints/2015/ preprint_10_2015.pdf?_blob=publicationFile.

HÖGSELIUS, Per. Red Gas: Russia and the origins of European energy dependence. New York: Palgrave Macmillan, 2013.

KRAUSE, F; BOSSEL, H; MÜLLER-REISSMANN, K. F. Energie-wende: wachstum und wohlstand ohne erdol und uran: Ein Alternative Bericht. Frankfurt am Main: S. Fischer, 1980.

LAIRD, Frank A; STEFES, Christoph. The diverging paths of German and United States policies for renewable energy: Sources of difference. Energy Policy 37, 2009, p. 2619-2629.

MATTHEWS, John A. Greening of Capitalism: How Asia is driving the next great transformation. Stanford: Stanford University Press, 2015.

MATTHEWS, John A. The renewable energies technology surge: A new techno-economic paradigm in the making? Working Papers in Technology Governance and Economic Dynamics no. 44. 2012. Available in: https://econpapers.repec.org/paper/tthw paper/44.htm

MATTHEWS, John A. Why China is becoming a renewables super power, and the West is not. Renew Economy. 29 May, 2015. Available in: http://reneweconomy.com. au/why-china-is-becoming-a-renewables-super-power-and-the-west-is-not-15031/. Accessed: 07.02.2017. 
MATTHEWS John A. Why the future belongs to decentralised renewables. ReNewEconomy. 2016. Available in: http://reneweconomy.com.au/future-belongs-decentralisedrenewables-37294/. Accessed in: 14.01.2017.

MORRIS, Craig. Germany has surpassed its 2020 target for green power. Energy Transition. The Global Energiewende. 02.08.2017. Available in: https://energytransition. org/2017/08/germany-has-surpassed-its-2020-target-for-green-power/. Accessed in: 19.09.2017.

QUITZOW, L., et al. The German. What's Happening? Introducing the Special Issue. Utilities Policy, 2016 Available in: http://dx.doi.org/10.1016/j.jup. 2016.03.002. Accessed: 15.08.2016.

ROEHRKASTEN, Sybille; WESTPHAL, Kirsten. IRENA and Germany's Foreign Renewable Energy Policy Aiming at Multilevel Governance and an Internationalization of the Energiewende? Working Paper FG 8, 2013/01, September 2013 SWP Berlin.

SMIL, Vaclav. Revolution? More like a crawl. Politico. 05/26/2015. Available in: http:// www.politico.com/agenda/story/2015/05/energy-visionary-vaclav-smil-quicktransformations-wrong-000017\#ixzz4I9e2KxeL. Accessed in: 23.08.2016.

SOKOL, Lena. Germany: the career of Christian Democratic Union leader Angela Merkel. World Socialist Web Site. 9 July 2005. Available in: https://www.wsws.org/en/ articles/2005/07/cdu2-j09.html). Accessed in: 08.08.2016.

WETTENGEL, J.. German carbon emissions rise in 2016 despite coal use drop. Clean Energy Wire. 2016. Available in: https://www.cleanenergywire.org/news/germancarbon-emissions-rise-2016-despite-coal-use-drop

THE ECONOMIST. What has gone wrong with Germany's energy policy. December $14^{\text {th }}$, 2014. Available in: http://www.economist.com/blogs/economist-explains/2014/12/ economist-explains-10. Accessed in: 19. 05. 2016. 


\section{Instruções editoriais para os autores}

Os autores devem seguir estritamente as diretrizes abaixo; sua não observância poderá implicar em não aceitação do artigo submetido, sendo os autores orientados a adequar o arquivo submetido aos padrões requeridos.

1. O artigo deve ser inédito e redigido em português ou em inglês. Além de inédito, o artigo não deve estar em apreciação concomitante em nenhum outro periódico ou veículo de publicação, no todo ou em parte, no idioma original ou traduzido.

2. O arquivo a ser enviado deve estar em formato.doc ou.docx; use somente a formatação padrão do texto. Os autores devem retirar sua identificação das propriedades do arquivo.

3. Não serão aceitos artigos com mais de 4 (quatro) autores/co-autores. No caso de mais de dois autores, a equipe editorial se reserva o direito de solicitar informações sobre o papel de cada um dos autores no processo de desenvolvimento do artigo.

4. O autor deve submeter três arquivos:

4.1 Um arquivo contendo título, resumos, palavras chave, corpo do texto e referências. No texto do artigo, o responsável pela submissão deve eliminar qualquer referência que possa permitir sua identificação.

4.1.1 No caso de um trabalho fruto de pesquisa financiada, o autor deve abrir uma nota de rodapé na primeira página do artigo para se referir ao financiamento e às agências de fomento que o possibilitaram.

4.2 Um arquivo, a ser submetido como suplementar, contendo a identificação dos autores, sua titulação máxima e a instituição a qual se encontra atualmente filiado, um resumo do Curriculum vitae de, no máximo, 5 linhas, contendo titulação, função que desempenha na instituição à qual é filiado e a URL do Currículo Lattes. Em casos de artigos com múltiplos autores, a informação de todos os autores deve ser apresentada. Neste mesmo arquivo, o autor poderá incluir agradecimentos, se desejar.

4.3 Uma Carta ao Editor, que deve ser enviada também como arquivo suplementar, na qual assume que o conteúdo do trabalho apresentado é inédito, não contém nada que possa ser considerado ilegal, difamatório, que cause conflito de interesses ou que possa interferir na imparcialidade do trabalho apresentado. 
5. O arquivo com o corpo do texto não deve conter nenhuma forma de identificação dos autores; a formatação do texto deve estar em espaço simples; fonte de 12 pontos; uso do itálico em vez de sublinhado (exceto em endereços URL); as figuras e tabelas devem ser inseridas no texto, e não no final do documento na forma de anexos.

6. O artigo deve conter o mínimo de 7.000 e o máximo de 8.000 palavras, incluídos título, resumo e palavras chave (em português e em inglês), corpo do texto e notas de rodapé; excluídas as referências.

6.1 Serão adotadas no máximo cinco palavras-chave em cada idioma. Elas devem se referir ao objeto de estudo do artigo e ao referencial teórico e/ou temática utilizada para análise.

7. O artigo deve incluir um resumo em português e em inglês, entre 150 a 200 palavras para cada uma das versões. Lembramos que o resumo em ambos os idiomas integra o número mínimo e o máximo de palavras, conforme indicado no item 6.

8. As notas de rodapé devem se restringir a esclarecimentos adicionais ao texto. Todas as referências de fonte bibliográfica ou outras deverão ser feitas no corpo do texto, conforme o sistema de citação Chicago (AUTOR, data).

8.1 As citações devem estar no mesmo idioma que o artigo. Assim, será acrescentada no corpo do texto a versão traduzida, e em nota de rodapé, a versão original da citação.

9. A formatação de tabelas, quadros e figuras deverá seguir o formato ABNT.

10. As referências devem ser listadas ao final do texto e devem se restringir àquelas efetivamente citadas no artigo. Deve ser observado estritamente o sistema Chicago (AUTOR, data). Não serão aceitas referências bibliográficas em notas de rodapé.

As mesmas deverão seguir os modelos abaixo, de acordo com o formato estabelecido pela NBR 6023 (2002) da ABNT.

10.1 Para artigos ou documentos eletrônicos:

Elementos: AUTOR(es). Título. Título da publicação. Local de publicação, numeração correspondente ao volume, número, mês e ano de publicação, paginação inicial e final. Indicar o endereço (link) onde o documento está disponível e a data de acesso ao artigo.

MIYAMOTO, Shiguenoli. Política Externa Brasileira: 1964-1985. Carta Internacional, v. 8, n. 2, 2013, p. 3-19. Disponível em: http://www. cartainternacional.abri.org.br/index.php/Carta/article/view/120/64. Acesso em: 14 jul. 2016. 
10.2 Para Livros

Elementos: AUTORES(es). Título. Edição (a partir da $2^{a}$ edição). Cidade: Editora, ano de publicação.

SARAIVA, José Flávio S. Foreign Policy and Political Regime. Brasília, DF: IBRI, 2003.

10.3 Para capítulos de livros:

Elementos: AUTOR(es) do capítulo. Título do capítulo. In: AUTOR(es) da obra (Org., Ed., Coord.) Título da obra. Edição (a partir da $2^{a}$ edição). Cidade: Editora, ano de publicação. Capítulo consultado e paginação da parte.

SNIDAL, Duncan. The politics scope: endogenous actors, heterogeneity and institutions. In KEOHANE, Robert O; OSTROM, Elinor. Local commons and global interdependence: heterogeneity and cooperation in two domains. London: Sage Publication, 1995. Cap. 2, p. 47-70.

10.4 Trabalhos apresentados em Eventos

Elementos: AUTOR(es). Título do trabalho apresentado. In: nome do evento, numeração do evento (se houver), ano e local (cidade) de realização, título do documento (anais, atas, tópico temático), local, editora, data de publicação e página inicial e final da parte referenciada.

VENTURA, Deisy de Freitas Lima; PEREZ, Fernanda Aguilar. A política externa de saúde de Dilma Rousseff (2011-2014): elementos preliminares para um balanço. In: $5^{\circ}$ Encontro Nacional da ABRI, 2015, Belo Horizonte. Anais Eletrônicos. Disponível em: < http://www.encontronacional2015. abri.org.br/site/anaiscomplementares?AREA = 14\%2017 > . Acesso em: 14 jul. 2016.

11. No ato da submissão, todas as informações requeridas no sistema deverão ser devidamente preenchidas.

\section{Condições para submissão}

Como parte do processo de submissão, os autores são obrigados a verificar a conformidade da submissão em relação a todos os itens listados a seguir. As submissões que não estiverem de acordo com as normas serão devolvidas aos autores.

1. A contribuição é original, inédita e não está sendo avaliada para publicação por outra revista. Caso contrário, deve-se justificar em "Comentários ao editor”. 
2. O arquivo da submissão está em formato Microsoft Word, OpenOffice ou RTF.

3. URLs para as referências foram informadas quando possível.

4. O texto está em espaço simples; usa uma fonte de 12-pontos; emprega itálico em vez de sublinhado (exceto em endereços URL); as figuras e tabelas estão inseridas no texto, não no final do documento na forma de anexos.

5. O texto segue os padrões de estilo e requisitos bibliográficos descritos em Diretrizes para Autores, na página Sobre a Revista.

6. Em caso de submissão a uma seção com avaliação pelos pares (ex.: artigos), as instruções disponíveis em Assegurando a avaliação pelos pares cega foram seguidas. 

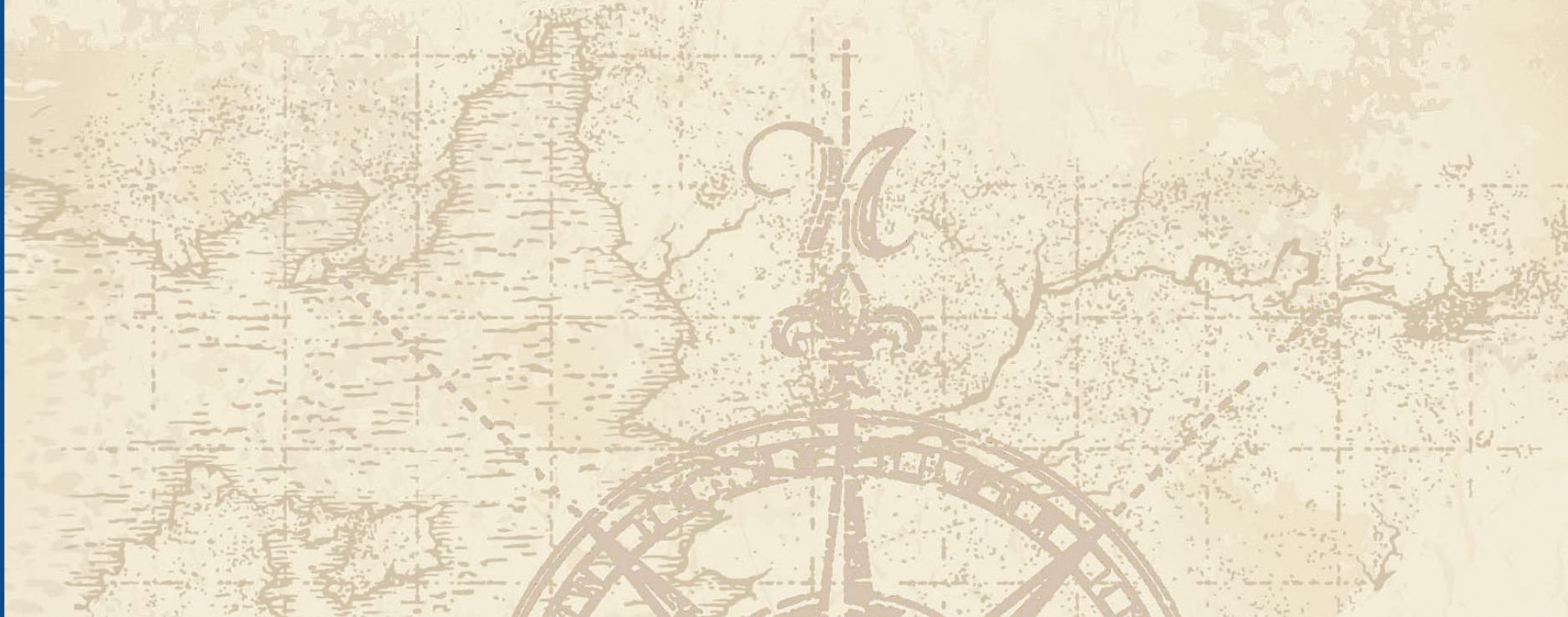

for

$=0-(x)$

$=3$
-0.4
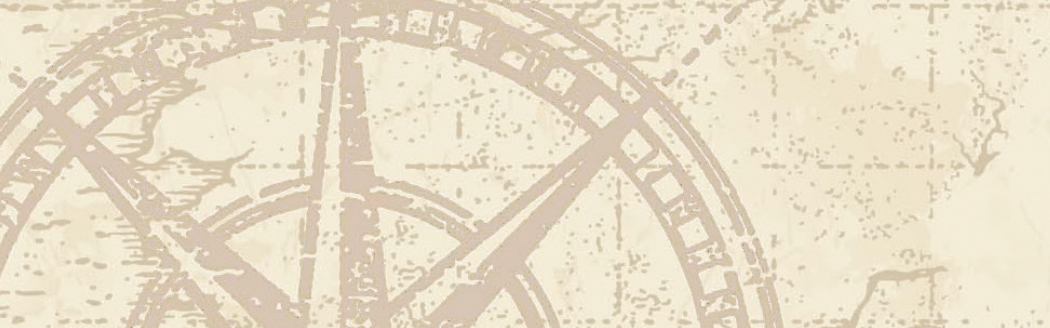